\title{
PERCIVAL LAFER
}

PROJETO E INDUSTRIALIZAÇÃO NO BRASIL 


\section{PERCIVAL LAFER}

PROJETO E INDUSTRIALIZAÇÃO NO BRASIL

Dissertação apresentada ao programa de pós-graduação em Arquitetura e Urbanismo da Faculdade de Arquitetura e Urbanismo da Universidade de São Paulo como requisito parcial para obtenção do título de mestre em Arquitetura e Urbanismo.

Área de concentração:

Design e Arquitetura

Orientadora:

Profa. Dra. Maria Cecília Loschiavo dos Santos 
Autorizo a reprodução e divulgação total ou parcial deste trabalho, por qualquer meio convencional ou eletrônico, para fins de estudo e pesquisa, desde que citada a fonte.

Catalogação na Publicação Serviço Técnico de Biblioteca

Faculdade de Arquitetura e Urbanismo da Universidade de São Paulo

Gutierrez, Gabriel Dozzi

PERCIVAL LAFER - PROJETO E INDUSTRIALIZAÇÃO NO BRASIL / Gabriel Dozzi Gutierrez; orientadora Maria Cecília Loschiavo Dos Santos. - São Paulo, 2018. $224 \mathrm{P}$.

Dissertação (Mestrado) - Faculdade de Arquitetura e Urbanismo da Universidade de São Paulo. Área de concentração: Design e Arquitetura

1. Mobiliário Brasileiro. 2. Design e Sociedade. 3. Industrialização. 4. Modernismo. 5. Pensamento de Projeto. I. Dos Santos, Maria Cecília Loschiavo, orient. II. Título.

Elaborada eletronicamente através do formulário disponível em: <http://www.fau.usp.br/fichacatalografica/> 
Nome: GUTIERREZ, Gabriel Dozzi

TíTuLO: Percival Lafer - projeto e industrialização no Brasil

Dissertação apresentada ao programa de pós-graduação em Arquitetura e Urbanismo da Faculdade de Arquitetura e Urbanismo da Universidade de São Paulo como requisito parcial para obtenção do título de mestre em Arquitetura e Urbanismo.

Aprovado em:

Banca examinadora:

Prof. Dr. Institução

Julgamento Assinatura

Prof. Dr. Institução Julgamento Assinatura

Prof. Dr. Institução Julgamento Assinatura 
aos do coração, 
Agradeço carinhosamente todos aqueles que, direta e indiretamente, colaboraram para a concretização desta pesquisa.

Muito obrigado a Maria Cecilia Loschiavo, pelo acompanhamento, carinho e amizade; a Sophia e Carolina Gutierrez, pelas horas de revisão e apoio; a Felipe Gutierrez e Claudia Dozzi, pelas trocas únicas e sabedoria; 
RESUMO

O texto que segue apresenta, em perspectiva, a trajetória de atuação de Percival Lafer - designer e industrial brasileiro. Apesar de ter ficado à sombra da historiografia, o designer contribuiu enormemente para a formação do que podemos considerar hoje o mobiliário nacional, dentro do âmbito comum das definições sobre design ligado à produção industrial.

A pesquisa lança bases para novos pensamentos acerca do modernismo e sua duração no tempo, bem como sobre a atuação de profissionais da arquitetura e desenho industrial durante os anos da ditadura militar brasileira. Delineia-se assim, um período da historiografia do design que pode ser considerado transitório - salto das bases produtivas artesanais ao movimento desgovernado da industrialização nacional.

Aorganização de um panorama iconográfico, detalhadamente comentado, enseja delinear o processo de criação de Lafer e sua relação com outras instâncias de atuação. A reflexão sobre a especificidade da linguagem projetual voltada à indústria coloca frente a frente a concepção de Percival Lafer às demais tentativas, ainda atuais, de organização de um desenho propriamente industrial e moderno.

Por último, apresentamos impressões sobre a falência do movimento moderno no Brasil e sua persistência discursiva frente as urgências e necessidade de um país que exige outra lógica de ordenação do mundo material.

\section{PALAVRAS CHAVES}

mobiliário brasileiro, design e sociedade, industrialização, modernismo, pensamento de projeto 


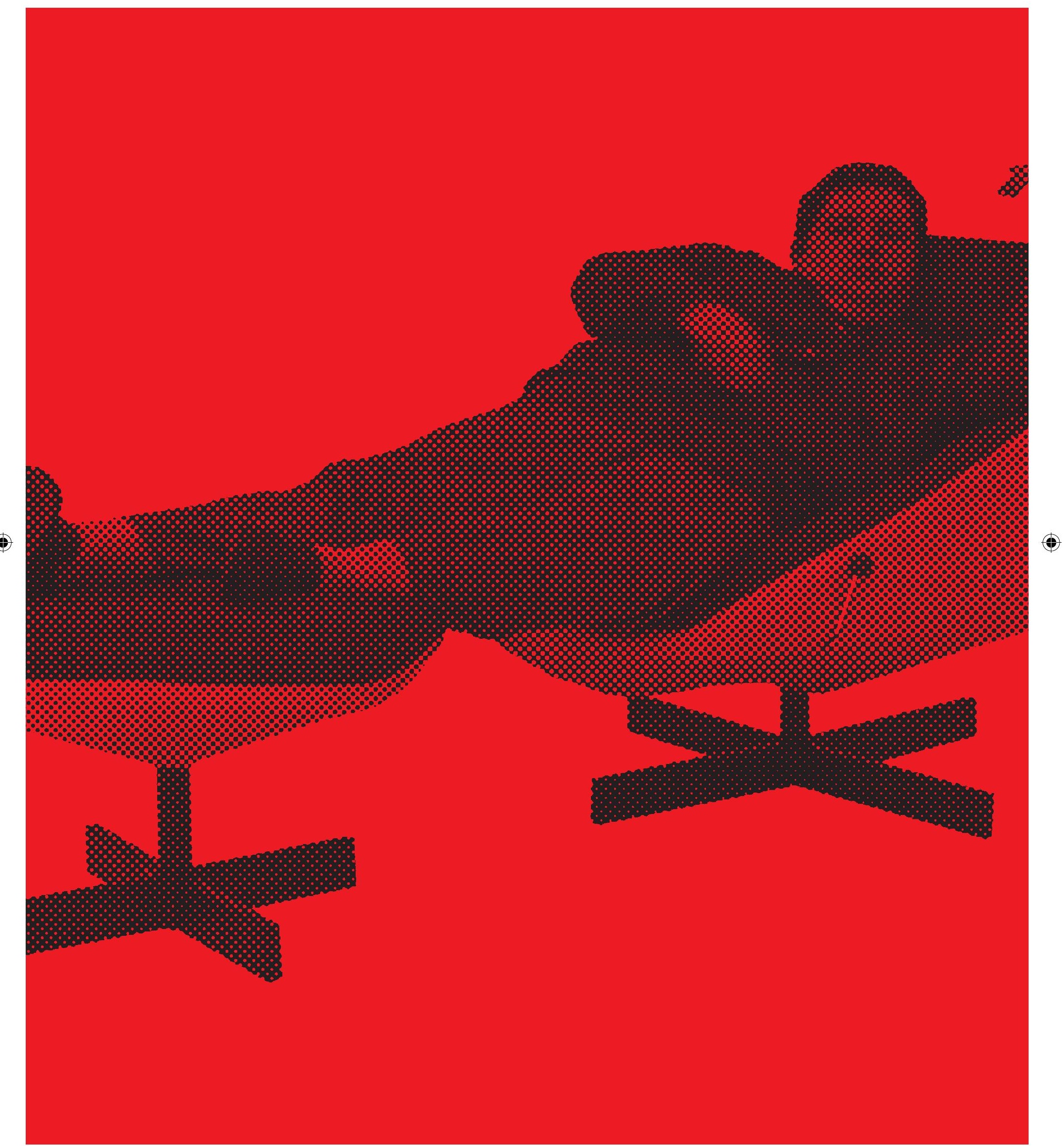




\section{ABSTRACT}

The following text presents, under perspective, the work trajectory of Percival Lafer, brazilian designer and industrial. Despite having remained in the shadows of historiography, the designer have enormously contribute to the formation of what we today consider the "national furniture", within the scope of conceptual definitions about the design related to industrial production.

The research lays foundations to new considerations regarding modernism and its endurance over time, as well as to the role of architecture and industrial design professionals during the years of the brazilian military dictatorship. It is therefore outlined a period of the design historiography that might be considered transitory, a moment of leap from the primary productive basis towards the unbridled movement of our national industrialization.

The organization of a iconographic panorama, commented in details, aspire to outline the creative process of Lafer and its bonds with other instances of work. The reflexion about the specificity of a project language turned to the industry, confronts Percival Lafer conceptions to the other attempts, still very current, of organization of a design properly modern and industrial.

At last, we present impressions over the failure of the modern movement in Brazil and its discursive persistence front the urgencies and needs of a country that demands a different logic of organization of the material world.

\section{KEY-WORDS}

brazilian furniture; design and society; industrialization; modernism; design thinking; project thinking 


\section{SUMÁRIO}

Resumo

Introdução

Capítulo 1. Contexto e experiência de Percival Lafer

_Casa de Móveis Lafer - história e legado

_ Os anos de formação e primeiras experiências modernas

_ MP LAFER - Consolidação da marca e impulso dos anos de industrialização

_Lafer e o automóvel - sofá sobre rodas

Capítulo 2. Panorama iconográfico sobre a produção da MPLAFER

_Primeiros projetos, primeiros produtos

_ O sofá-cama

_ Final 1 e 3 - linhas de luxo para a exportação

128

_Conjuntos modulares

162

_Linhas especiais

167

_Linhas Países

174

_As reclináveis

Capítulo 3. Considerações Finais - o moderno no Brasil, sobre a fé apaixonada 

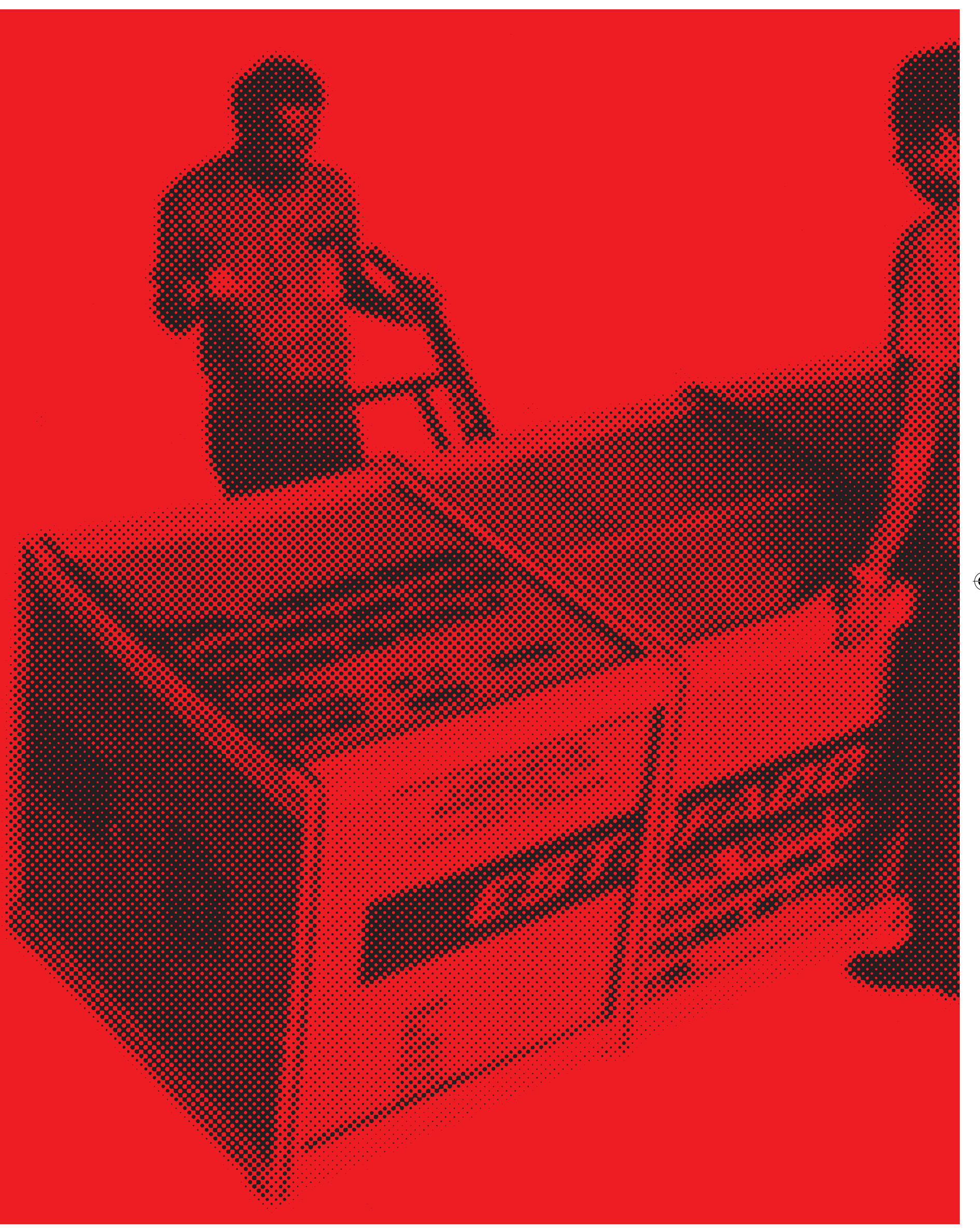


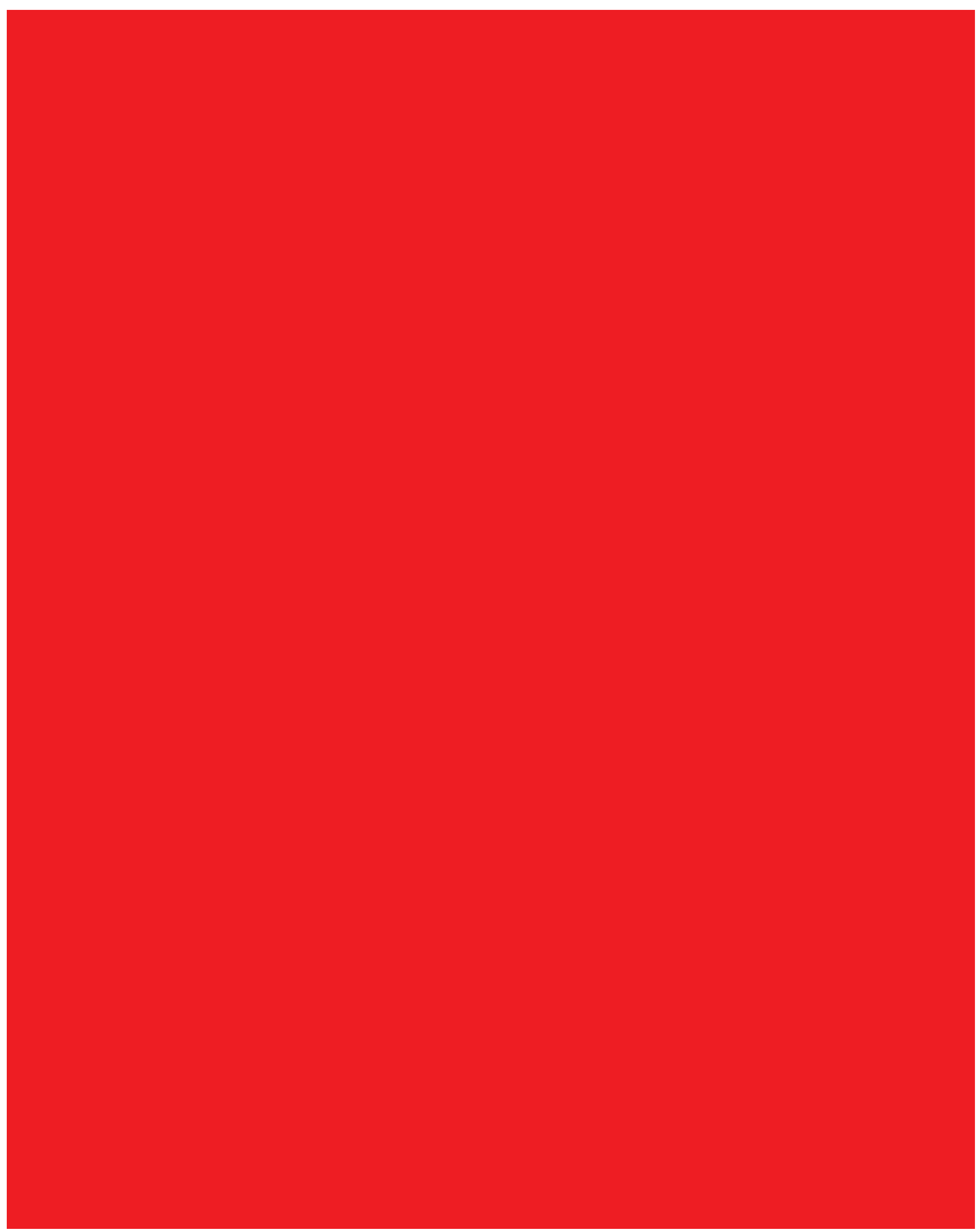

$\oplus$ 
Pg. 16 e 77 - foto

de carregadores

da Lafer.

Fonte: arquivo

do designer

A casualidade do achado foi o ponto de partida para a pesquisa que apresentaremos aqui. O primeiro contato com a obra de Percival Lafer se deu por acaso, durante um garimpo de peças da mobília modernista. Um conjunto de poltronas de sala instigou a busca pelo responsável pelo desenho das peças até então desconhecidas. Claramente, aqueles móveis eram resultado de um projeto. Em um primeiro momento, pensamos ter encontrado mais um exemplar de poltronas de segunda linha produzidas por casas de decoração que seguiam o estilo moderno dos grandes designers, comercializando produtos inspirados1. Tal especulação não se confirmou. Algum tempo depois, a pesquisa em antiquários internacionais revelou a autoria das peças. As poltronas outrora encontradas eram um par da linha MP51, assinadas pelo designer de nome Percival Lafer.

Com o aprofundamento da pesquisa, percebeu-se que os móveis modernistas criados por Percival Lafer não estavam disponíveis no mercado brasileiro. Atestamos, por meio do contato com antiquaristas, que o desconhecimento sobre a obra do designer imperava, embora muitos profissionais da área conhecessem seu nome, sempre muito atrelado ao desenho de estofados, poltronas reclináveis e da produção do automóvel MP LAFER. Os produtos fabricados entre as décadas de 60 e 80, caros pela expressividade do desenho, próprio a reprodução das tendências estilísticas do moderno, haviam permanecido no limbo.

A sistematização da pesquisa trouxe ao conhecimento uma série

1 Esse era o caso de algumas fábricas de móveis que surgiram ao longo dos 1960. Para citar alguns exemplos, podemos mencionar as casas 'Celina Decorações', 'Móveis Fátima' ou 'Tora arquitetura'. Os móveis de estilo moderno, principalmente os de autor, foram copiados e adaptados a uma realidade de consumo mais acessível. Esse era o âmbito de atuação dessas casas e fabriquetas de móveis. (N.d.A.) 
de outras peças de propostas peculiares, também criadas por Percival Lafer. A inexistência de estudos sobre sua obra, bem como a escassez de fontes confiáveis, tanto de imagens como de dados factuais, dificultou o processo de pesquisa. Apenas por meio do contato direto com o designer, conseguimos avançar de forma precisa. Lafer, que ainda produz no campo da indústria mobiliária, colocou à disposição seu acervo de imagens, que confirmaram a autoria das peças outrora levantadas. Por meio da análise de fotografias, registros dos mais diversos, projetos, materiais de publicidade, foi possível entender as questões que deveriam conduzir a pesquisa. As entrevistas realizadas foram grande fonte de informação. Por meio delas, pudemos delimitar algumas linhas de análise e condução.

Percebendoque umaabordagem biográficaseriaparciale pouco aprofundada, preferimos recorrer a um processo de compreensão da obra em questão, para além dos traços subjetivos do designer. O intuito foi, desde o início, decifrar a imbricação entre o processo criativo em design e a singular trajetória industrial traçada por Lafer, fundamentando uma análise crítica e contextualizada, que pudesse lançar novas bases para a compreensão do desenvolvimento do desenho industrial e da produção do móvel moderno no Brasil.

Diversas dúvidas imperavam, e algumas delas se consolidaram à medida que a pesquisa avançava. $O$ estudo de campo para levantamento e reconhecimento de material e documentação pertinente foi de importância basilar para a estruturação da pesquisa. Partimos do princípio de que qualquer teorização só poderia se tornar possível e válida caso houvesse embasamento concreto no material elegido. Sendo o foco da pesquisa, a análise crítica de uma produção em design e de seu contexto, a inventariação e organização das fontes iconográficas pautaram os enfoques dados à dissertação. A reflexão teórica e a consequente delineação da bibliografia necessária foram construídas conjuntamente com esse movimento prático de catalogação e pesquisa documental.

Definiram-se, assim, alguns procedimentos metodológicos como guias essenciais à montagem da dissertação. A primeira medida adotada foi o estudo dos arquivos do designer - processo gradual e de forte importância, já que, além de não organizada, 
a documentação avaliada mostrou-se bastante vasta. As fontes e documentos foram separados por tipologia, a partir de quatro grandes eixos de produção: "arquitetura e seus elementos construtivos", "equipamentos urbanos", "mobiliário" e "automobilística". Das quatro tipologias, duas se apresentaram incipientes, ainda que não menos importantes, a saber, "arquitetura e seus elementos construtivos" e "equipamentos urbanos", e, por isso, decidimos não aprofundar em sua abordagem. As duas outras tipologias - "mobiliário" e "automobilística" - formaram o eixo central da pesquisa, interligando-se a um cenário propício para a análise de projeto e produto de Percival Lafer. Percebeu-se que a forma industrial de produção concatena, neste ponto, a algo que se torna prática e simbolicamente indissociável: carro e móvel dividem a mesma base de raciocínio projetual e de concepção na cabeça do designer. Durante décadas, Percival desenvolveu tecnologias aplicadas à criação de seus móveis, estruturando uma linha de montagem sob a égide do modelo fordista de produção. Setores foram criados para dar vida aos projetos que eram pensados como um quebra-cabeça de encaixes e mecanismos - soluções próprias ao pensamento do projeto automobilístico, relacionado à pesquisa de engenharia. Da base industrial, emprestou-se toda a técnica produtiva para a fatura do mobiliário livre do aspecto artesanal. Como exemplo, podemos citar o desenvolvimento da tecnologia do fiberglass: espuma injetada e moldada - engenharia necessária para o desenvolvimento de peças e mecanismos cinéticos. O caminho do mobiliário apontou para a fabricação de um carro. Na década de 70, o lançamento de um calhambeque, o MP LAFER, se mostrou no mínimo curioso, frente ao resto da produção do designer. Neste ponto, além da lógica projetual e produtiva, identifica-se um desvio simbólico, no qual estilo e tendência, mercado e subjetividade entram em jogo. O carro nada mais é do que um móvel de rodas. Essa situação pitoresca servirá como exemplo dos tipos de percurso que serão analisados na dissertação a ser apresentada.

Outro aferimento é o de que o designer pertence a um período de transição próprio ao momento histórico correspondente. Lafer industrializou-se durante o período da ditadura, e como outros tantos designers e arquitetos, teve que se adequar às novas demandas econômicas e sociais do Brasil naquele momento. Enquanto designer, foi um dos poucos que conseguiu fazer a transição entre as bases artesanais de produção do mobiliário e a grande escala industrial de fabricação e 
venda. Sua trajetória exemplifica como os caminhos das teorias e práticas do moderno foram suspensas durante a ditadura e ainda hoje não conseguiram apontar outros rumos dentro do delicado campo de tangência entre a criação do mundo material e o contexto social brasileiro. Em sua trajetória desviante, Percival fez uso retórico do estilo moderno, produzindo peças que, embora hoje se confirmem historicamente, são prova da fragilidade do movimento em questão, em detrimento ao que podemos chamar de reais necessidades. Talvez a produção do designer exponha, em certa medida, os posicionamentos de responsabilidade adotados (ou abandonados) pela comunidade dos profissionais da arquitetura e do design, dentro da ótica do campo das ciências sociais aplicadas.

Sendo assim, o compendio tem como finalidade apresentar a produção do designer de forma contextualizada, sempre a partir do pensamento crítico sobre a produção industrial e a crescente influência do design enquanto diretiva de dominação. Também pretendeu-se significar minimamente as condições da criação no campo da arquitetura e design durante o período específico da ditadura militar brasileira, para poder, assim, compreender como o designer em questão ocupa um lugar de transição entre o moderno e sua diluição.

Para tanto, o primeiro capítulo destina-se a apresentação do designer e de suas experiências pessoais enquanto criador, aprofundando aspectos sobre o percurso singular de Percival Lafer no campo de sua formação e profissionalização. Analisamos o histórico do designer, em meio ao contexto histórico, social e estético que conduziram ao desenvolvimento industrial de produção da MP Lafer (Móveis Patenteados Lafer). Analisamos diversas fases de produção do designer e de sua lógica projetual e discursiva, além de expor dados importantes para conduzir o leitor aos capítulos subsequentes.

Ainda nesta parte, consideramos como a educação formal vigente da época, frente ao pensamento moderno, já destilado, influenciou profundamente os caminhos adotados pelo designer. Esses aspectos ajudam a pontuar como o conceito de design foi calcado ao longo do tempo, e em que âmbito Percival Lafer atuou. Por meio da análise do discurso criado em torno da fundação da 
empresa e marca MP Lafer, debatemos os limites entre o estilo e a correspondência das tendências de época nacionais e internacionais no campo do design.

Partimos do pressuposto de que a criação do móvel moderno coincide com o surgimento de um discurso que, ao longo dos anos, foi sendo destilado e modificado, conforme as transformações de mercado. A proposta inicial da MP LAFER se resumia à produção e venda de móveis que aparentassem serem produzidos artesanalmente, mas que, ao mesmo tempo, seguissem a lógica da escala de produção industrial. As peças deveriam ter um desenho tão exclusivo, que necessitariam de patentes para a proteção contra as cópias. Que a escala industrial de produção se encontra no cerne da preocupação modernista é um fato, no entanto, o caminho percorrido pela MP LAFER é inverso a este movimento. A estruturação foi primordialmente industrial, sendo que a preocupação discursiva e de validação negou o rastro da máquina, na afirmação de uma aura autoral "modernista", baseada no artesanal e único.

A questão que aqui se coloca é: quais são os limites existentes entre o discurso e a prática, e como esse contexto está diretamente ligado ao pensamento industrial de produção? Qual jogo o design desempenha para se estabelecer hegemônico? Quais são os truques criados para a criação e inserção de um produto no mercado? No caso do designer em questão, existe um desvio neste âmbito, no que diz respeito às formas de veiculação e produção do mobiliário. Não é em vão que, no auge de sua maturidade, a empresa tenha produzido um carro completamente anacrônico em sua concepção. A partir desse ponto, a discussão concentrou-se nas vertentes a serem exploradas nos capítulos subsequentes, tratando da produção dos móveis e a fabricação do Cabriolet MP.

Outra necessidade de pesquisa identificada, no que diz respeito ao estudo do design e da arquitetura, é o entendimento, tradução e sistematização do pensamento de projeto enquanto parte intrínseca da lógica de criação. Pode-se traduzir esse aspecto, grosseiramente, como o escrutínio do raciocínio do criador e de todo o aparato e contexto que, juntos, delineiam seu ato de projetar. Tentar entender como funciona o mecanismo da cabeça do designer, possibilita a identificação das regras e desvios de sua atuação na disciplina estudada. Esse exercício também colabora, por comparação, para a compreensão de como os seus pares se posicionavam enquanto projetistas. O pensamento de projeto é o que 
possibilita uma catalogação e disposição coerentes do material projetual recolhido. Pensar e fazer, no caso de Percival Lafer, são duas ações indissociáveis. Ambas deram forma a sua produção, que, por sua vez, se consolidou dentro da escala industrial. Assim, o designer e o industrial, são também indistintos.

O segundo capítulo concentra-se, por meio do panorama iconográfico das obras do designer, na concepção do projeto, suas características, variações e aspectos que se encontram no caminho existente entre a ideia e a materialização.

No caso de Percival Lafer, projeto e execução se unem. O designer atua como prototipista e o projeto acontece simultaneamente à fatura. Por meio de desenhos e imagens, identificamos os processos de criação do designer, processos esses que marcam um percurso irregular e variável dentro da produção de uma única peça de design.

Finalmente, o terceiro capítulo contém as considerações finais. Nesta parte, avaliamos a importância da obra legada pelo designer, bem como seu ressurgimento dentro de um ciclo de reavivamento das tendências do moderno movidos pela moda do "vintage". Além disso, propomos uma investigação crítica sobre o significado social do design na atualidade e a falência dos ideias modernos de transformação, por meio da análise das obras de David Harvey, Hall Foster, Lina Bo Bardi e Theodor Adorno.

Para o embasamento bibliográfico da dissertação, foi de suma importância a leitura de autores como Mario Pedrosa, em seus ensaios críticos, Jean Baudrillard, no clássico O sistema dos objetos, bem como Maria Cecilia Loschiavo dos Santos, em toda sua produção sobre o mobiliário moderno brasileiro, e Gui Bonsiepe, em vários escritos sobre a conceituação do design.

Recorreu-se ainda à publicação Michel Arnoult, design e utopia - móveis em série para todos, de Ethel Leon, sobre o designer Michel Arnoult, que, contemporâneo de Percival Lafer, fez uso da mesma escala de produção industrial, ainda que sob outra concepção do design. Tal compêndio traz luz às questões envolvidas no processo de pensar a forma industrial de produção e sua inserção no mercado da época. Ainda para analisar a questão industrial brasileira em seu contexto histórico mais amplo, leu-se 
o livro clássico de Celso Furtado, Formação econômica do Brasil, editado pela Companhia das Letras; e o estudo de Sonia Draibe, Rumos e Metamorfoses. Estado e Industrialização no Brasil: 1930 a 1960, que nos forneceram maior base histórica dos movimentos socioeconômicos dentro dos quais encontra-se a atuação produtiva de Percival Lafer.

Além desses, as obras, com olhar interdisciplinar sobre o Design, de autores como Gui Bonsiepe, Jean Baudrillhard, Hall Foster e Vilém Flusser, encontraram importância na formulação e enriquecimento teórico desta dissertação. 


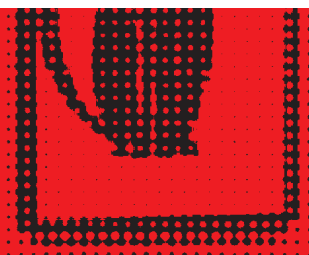

\section{4quph}

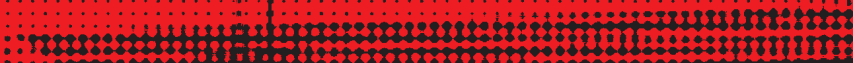

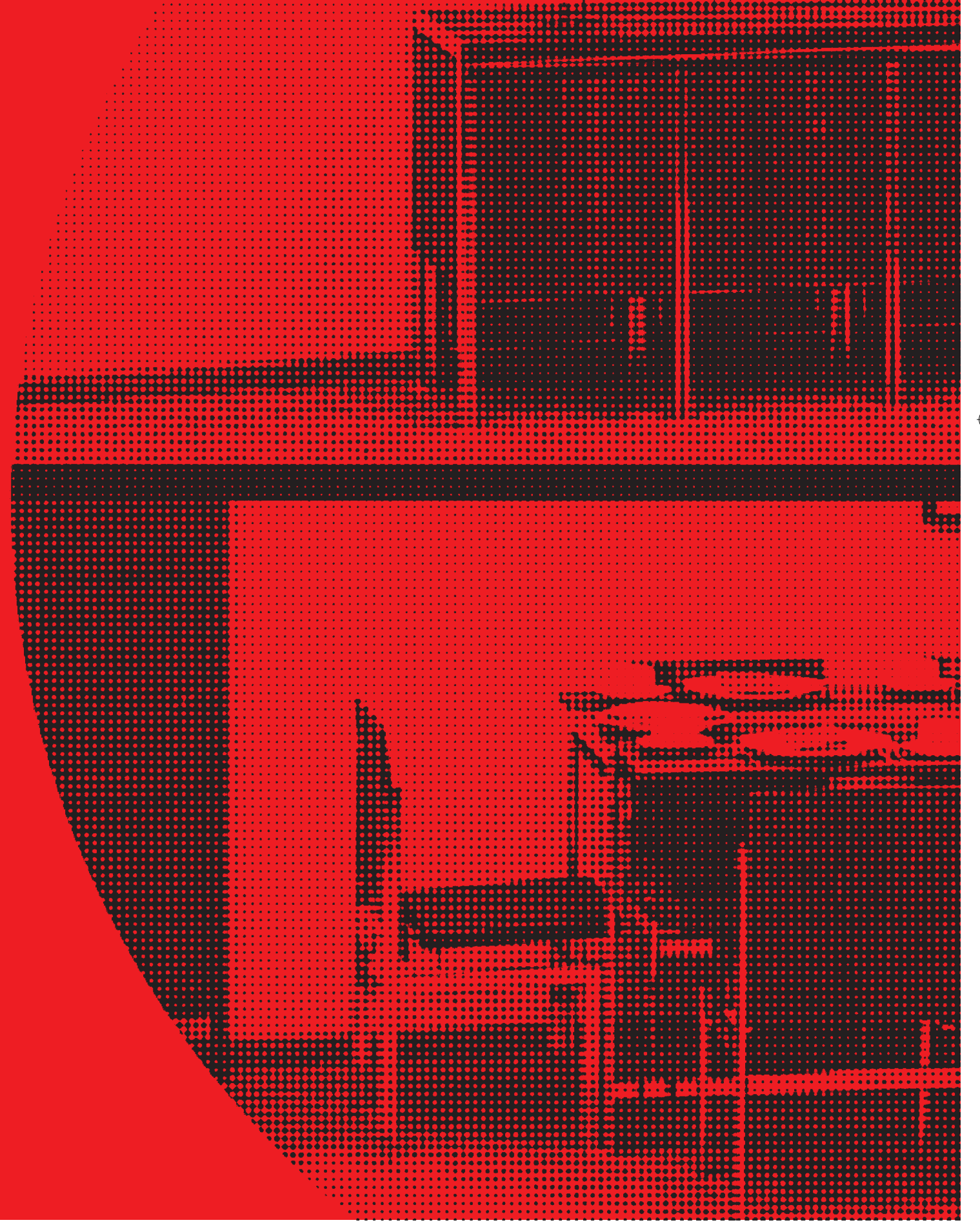




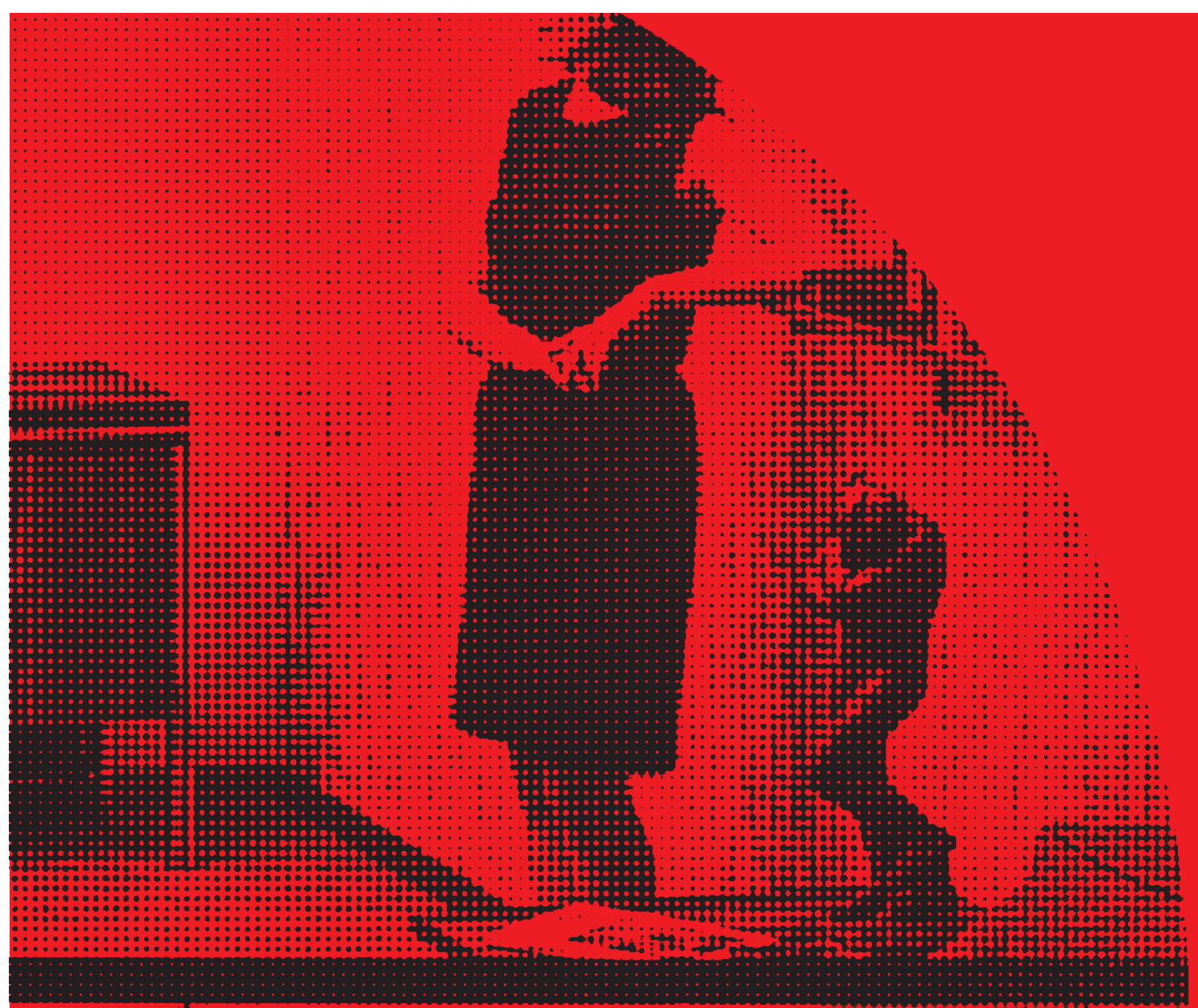

(4)

movintasto

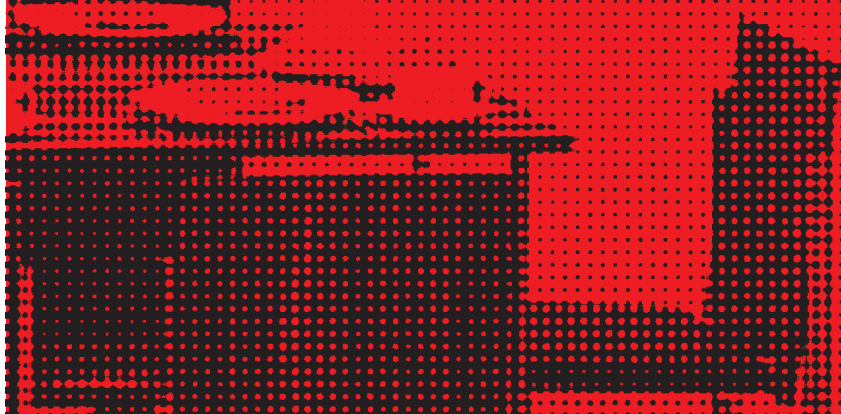

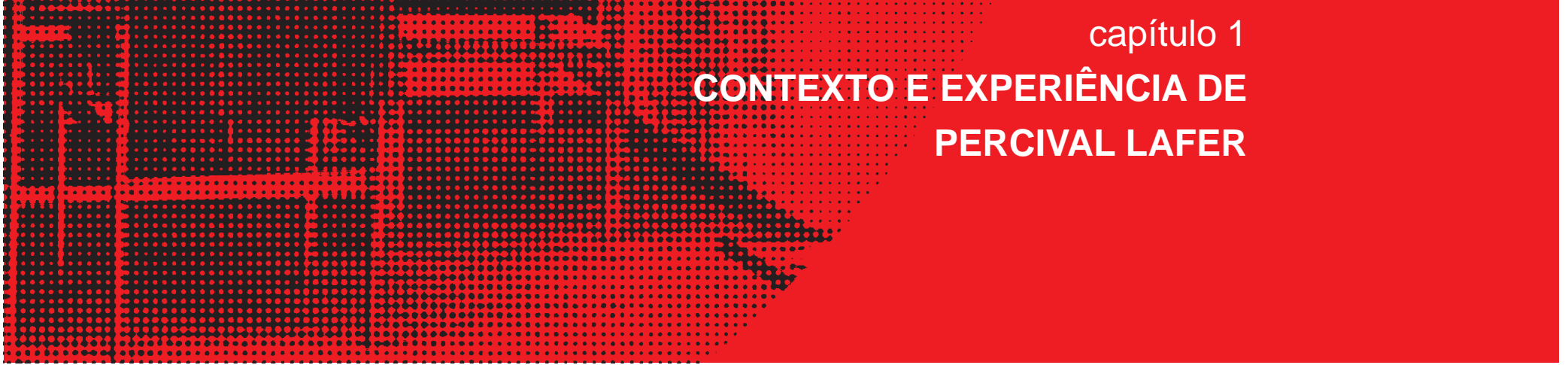


Pg. 26 e 27 - foto da Mini-Sala, desenhada por

Percival Laer, e premiada pela UD de 1962.

Fonte: arquivo do designer
Quando Percival Lafer começou a produzir nos anos 1960, os paradigmas de desenho e projeto modernistas estavam lançados. Os grandes mestres do modernismo já colhiam os frutos do reconhecimento de sua produção. Brasília estava construída, e o golpe militar estava sendo articulado. O ambiente era de grande agitação cultural, ao mesmo tempo que de incerteza. As promessas do Brasil progressista, euforicamente vividas desde os anos 50, estavam prestes a falir, e o estilo que as representava, na iminência de ser transformado. $O$ país estava prestes a viver o que Zuenir Ventura chamou de vazio cultural.2 Ao dissertar sobre os ideais modernos numa conferência da qual participou, já nos anos 1990, Lina Bo Bardi responde à pergunta sobre a existência de um design brasileiro:

"Com poucas exceções, até hoje não chegou a existir um design brasileiro. Infelizmente ou felizmente, o design está acabado. Aquilo que era a salvação da humanidade nos anos 1930, no tempo de Gropius e da Bauhaus, no tempo dos grandes arquitetos, aquilo que era um grande Oceano Pacífico virou uma manchinha de água suja no meio da rua depois de uma grande chuva. Isso é o design internacional: acabou no sentido de que não é mais a salvação do homem, nenhum homem pode se salvar pelo design. Um bonito copo salva da sede? Um prato muito bonito ou uma cadeira bonita nos salvam da fome, da miséria, da doença, da deseducação e do desemprego? Essa é a grande falha. Aquele sonho era bonito, mas era um sonho.3

2 VENTURA, 1971 apud ROSSETTI, Eduardo Pierrotti. 1964-85 - Arquitetura brasileira em transe. Vitruvius, São Paulo, abril de 2004. Disponível em <http://www. vitruvius.com.br/revistas/read/arquitextos/14.167/5183>. Acesso em: 10 de julho de 2017. Faz-se importante uma pequena ponderação sobre o termo "vazio cultural", cunhado pelo jornalista e professor universitário Zuenir Ventura. Iniciativas culturais e expressões de posicionamento político existiram durante a ditadura, principalmente nas áreas das artes cênicas e música. Muitos pensadores questionam o termo que deve ser considerado como uma caracterização de uma época que de fato tolheu os direitos de expressão livre, imprescindíveis ao fazer cultural e artístico. O choque ditatorial criou uma cisão e colocou aqueles que anteriormente estavam na linha de frente, em um estado de perplexidade e indefinição, para não dizer risco de morte. Muitos foram mortos em sua consciência artística. O estado das coisas no meio cultural era de suspensão, o que não bloqueou o fazer artístico das classes mais abastadas, mas vetou claramente a possibilidade de uma existência artística, a partir do tolhimento dos direitos básicos da população nacional. O período foi de transe. O próprio Zuenir identifica a fase como sendo uma "transição em que [a cultura], como superestrutura, tenta adaptar-se às alterações infra-estruturais surgidas no país [que deve enfrentar] características de uma cultura típica dos países industrializados (VENTURA, 2000, p.47)

3 RUBINO, Silvana e GRINNOVER, Marina (org.). Lina por escrito - textos escolhidos de Lina Bo Bardi. São Paulo: Cosac Naify:2009. 
Era essa transformação que estava em curso. O sonho moderno estava acabado, não houve tempo para que ele pudesse ser repensado, de acordo com uma perspectiva das necessidades e urgências nacionais. A ditadura militar estancou as possibilidades de revisão do moderno, e designers e arquitetos redobraram-se sobre uma forma de resistência engessada e estilística que não condizia com o discurso, e menos ainda, com a prática real do que o modernismo propunha enquanto transformação. Ao mesmo tempo em que outras atividades artísticas como as artes visuais, a música, o cinema e o teatro embrenharam-se na discussão trazida pelas correntes do nacional-popular, intensificando um posicionamento criativo e político, a arquitetura e, principalmente, o design recrudesceram suas discussões, sendo reduzidos assim, com o tempo, apenas às reproduções de tendências de estilo. As ligações com o poder e com o estado mudaram, e o campo da arquitetura e design perdeu coesão com a dispersão e pouca articulação dos profissionais. Com raras exceções muito expressivas, encabeçadas principalmente por Lina Bo Bardi 4, representante do modernismo brutalista juntamente com Vilanova Artigas, o moderno na arquitetura se transformou em uma casca cristalizada, que servia agora, declaradamente, como a roupagem das classes média e alta que apoiaram o golpe.

Maria Cecilia Loschiavo dos Santos, em seu extenso estudo sobre o móvel moderno no Brasil, deixa claro que as tentativas e experiências no campo do design eram pouco imbuídas de posicionamento político. As manifestações eram tênues5, senão inexistentes, e tocavam apenas questões cosméticas do processo de construção cultural. Em paralelo àqueles, que como Sérgio Rodrigues, iriam continuar a investir numa produção autoral, uma série de outros designers, preocupados com a difusão do móvel nacional, e aproveitando uma política de crescimento da

$4 \quad$ A atuação de Lina, de extrema envergadura poética e estética, considerou a problemática do moderno de frente: reduzido à questão da forma e de um mito nacionalista, perdeu toda sua essência transformadora. A arquiteta, de forma magistral e muito direta, conseguiu avançar na discussão moderna voltando-se para a o cerne da questão cultural autóctone brasileira. Lina talvez tenha sido a primeira a declarar a falência do moderno sem, no entanto, desacreditar no poder transformador de uma sociedade, a partir da escuta aos que nunca eram escutados. (N.d.A.)

5 SANTOS, Maria Cecília Loschiavo dos. Móvel Moderno no Brasil. São Paulo: Olhares, 2015. 
industrialização e da exportação incentivada pela economia da ditadura, enveredaram no aprofundamento das questões relativas à produção em série. Loschiavo nomeia as empresas "responsáveis pelas principais mudanças qualitativas e quantitativas da época":

"Nesse sentido destacaram-se as realizações de Michel Arnoult (1922-2005), Norman Weswater e Abel Barros Lima, associados a Mobília Contemporânea; a produção dos irmãos Haunes, na Móveis Artesanal, e, posteriormente, na Mobilínea; a contribuição de Karl Heinz Bergmiller, na Escriba Indústria, Comércio de Móveis Ltda; o trabalho de Geraldo de Barros, na Hobjeto Indústria de Móveis S.A., e a participação de um dos grandes animadores do desenho industrial em São Paulo, Leo Seincman (1919), fundador da Probjeto S.A. Produtos e Objetos Projetados." 6

Não foi a toa que o setor que mais cresceu durante esse período foi aquele que se especializou na produção de móveis de escritório. A setorização da indústria moveleira se dá por vários fatores, mas principalmente pela abrupta transformação, quase que compulsória, das bases de produção. A dinâmica especulativa baseada em uma cultura de massa era crescente. O móvel de madeira7, de autor, não tinham espaço na sociedade cerceada, e o móvel doméstico não era necessariamente prioridade, já que pequenos produtores e grandes redes comercializavam e supriam a população com móveis de baixa qualidade. Antes a questão em pauta era standartizar.

Percival Lafer viveu esse período de transição e, dessa forma, encarnou a figura de um designer de transição. Assim como as empresas de Michel Arnoult, talvez o único designer que tenha juntamente com Percival, investido e alcançado uma escala relevante de produção

6 Id. Ibidem.

$7 \quad$ O uso da madeira pode ser considerado um dos diferencias do mobiliário moderno nos anos anteriores ao golpe. A transformação dessa matéria, ainda mais considerando o dado simbólico que encerra para um país tropical, mundialmente conhecido pelas grandes reservas de madeira de lei, foi parte constituinte e fundante na criação de uma linguagem do móvel nacional. O jacarandá baiano, já, nessa época, escasso, contribuiu enormemente, juntamente com outras madeiras essenciais como o pau ferro, a caviúna, a sucupira, para a formação do ideário de representação nacional. (N.d.A.) 
industrial do mobiliário doméstico, a MP Lafer, se preocupou, desde sua fundação, com a escala de produção de seus móveis e, muito profundamente, com a difusão das peças. Diferentemente de Michel Arnoult, que se ocupou em criar a possibilidade de acesso popular ao móvel moderno nacional, Percival se ocupou em atender as classes mais altas. Não aprofundaremos nas questões relativas às experiências de Michel Arnoult, mas é fundamental citá-lo enquanto grande designer e pensador da indústria no Brasil, contemporâneo à Lafer.

Embora com atuações muito diferentes, ambos os designers partilharam da mesma visão industrial, pensando o projeto de forma complexa, em movimento a atender as diversas etapas de fabricação e difusão. Essa foi uma característica típica dos designers em atuação em países periféricos. Sobre a atuação de Michel Arnoult, Ethel Leon analisa esse lugar específico do industrial:

"Como já bem observou Guie Bonsiepe, o designer, na periferia do mundo, deve viabilizar a produção. Esse lugar é central para que sua atividade possa ser exercida. Michel Arnoult e muitos que se envolveram diretamente em atividades produtivas no Brasil passaram a trabalhar como empresários ou gestores para conseguirem exercer seu ofício de designers. [...] seria uma forma de centralizar os processos, que envolveriam, muitas vezes, o desenho das unidades produtivas." 8

Lafer tinha uma vantagem nesse aspecto. Quando começou sua produção, ele já contava com uma rede de representantes e revendedores que impulsionou seu crescimento. As bases comerciais haviam sido solidificadas pelo negócio moveleiro do pai, como veremos mais adiante. Além disso, Percival se mostrou, em todos os momentos da carreira, aberto à produção de projetos de fora, como, por exemplo, nos casos da produção de orelhões e outros elementos de fibra de vidro, técnica que dominava muito bem.

O designer pertenceu a uma geração que viveu a diluição do estilo moderno. Durante a entrada nos tempos sombrios da ditadura, o intuito

8 LEON, Ethel (org), Michel Arnoult, Design e Utopia - móveis em série para todos, São Paulo: Edições SESC, 2016, p.119-120 
de Percival foi de incrementar uma produção industrial que resultasse em um produto com cara artesanal, aos moldes da influência modernista que vivera em seus anos de formação. Não havia outra opção se não essa: seguir as tendências difundidas pelo moderno, mas dentro de uma dinâmica industrial de produção. O valor da manufatura havia mudado: mesmo quando a produção era artesanal, a cara do produto deveria apontar para o futuro. A modernidade, enquanto moeda de troca, virou símbolo de novidade e de progresso econômico já nas décadas anteriores, e essa imagem esvaziada perpetuou-se nos anos que se seguiram. O novo era a grande arma da indústria, que, para além da mecanização, trazia consigo a nova forma de pensar publicitária, duas instâncias que, no caso do ramo moveleiro, eram indissociáveis para o sucesso de vendas.

Embora Percival Lafer tenha contribuído para o aprofundamento e difusão do desenho do móvel moderno nacional, lançando bases sólidas para o pensamento de projeto direcionado ao incremento da produção industrial do mobiliário brasileiro, sua contribuição ficou à margem da historiografia do design nacional, como a de tantos outros profissionais que se embrenharam nas questões da produção em larga escala. Para compreender melhor esse silêncio, algumas considerações devem ser feitas.

A primeira delas está relacionada a uma característica pessoal do designer, que em momento algum se expôs enquanto criador da marca MP Lafer. Embora fosse sabido que ele era o proprietário e cabeça por trás do pensamento da marca, nenhuma publicidade ou esforço foi feito em direção a relacionar sua figura pessoal à produção da empresa. Essa não era uma preocupação, já que a priori, Percival não perseguia o [...] glamour artístico que legitimava [a atuação do arquiteto] em sua excepcionalidade anterior [...] 9 à instauração da ditadura, conforme a estruturação de um novo paradigma de atuação profissional.

Ainda, houve a diminuição, durante o período da ditadura, de veículos impressos especializados do ramo. Espaços que eram destinados à crítica minguaram. Dos que restaram, basicamente as revistas MÒDULO, ÁCROPOLE e HABITAT continuaram suas atividades de modo intermitentes. Percival Lafer não circulava nos meios que estavam se ocupando da pequena discussão acerca da situação cultural no país, e discussões sobre design eram inexistentes, ou muito insípidas. Sendo assim, não havia

$9 \quad$ ROSSETTI, op. cit. p.2. 
envolvimento intelectual por parte do designer com outros grupos, o que o isolou das discussões sobre o interesse público. Esse isolamento reduziu Percival à figura do industrial produtor de móveis para a elite, propagador da tendência moderna distorcida, o que de certa forma, desconsiderava a importância de sua atuação para o mercado e até mesmo a consolidação de seu estilo próprio. Embora a produção de Percival Lafer tenha sido desconhecida para a maioria das pessoas, profissionais da área ou não, o designer tem grande prestígio no exterior, para onde exportou seus móveis por mais de 20 anos. Os colecionadores, principalmente alemães, se referem ao designer como o "segredo mais bem guardado" do design "midcentury"10 brasileiro.

Percival foi acusado muitas vezes de ter copiado outros designers modernos da época, como Sérgio Rodrigues. Não vamos nos ater a questão da cópia, mas o fato é que tais designers, dos primeiros anos de modernismo, claramente influenciaram as gerações subsequentes, e influenciam até hoje. Defender uma produção completamente original é uma falácia, mesmo em se tratando dos grandes. Quando não, a estreita relação com o mercado consumidor, colocava Lafer em um patamar diminuído em relação ao que era considerado pertencente à cultura, para não dizer alta cultura, que é um termo bem ridículo. Essa distinção nos faz pensar no motivo de silenciamento sobre a obra de Percival Lafer, que foi, em certa medida, uma negação de sua produção por parte de estudiosos, pesquisadores, para não falar na crítica, que era quase inexistente no país.

A ditadura colocou fim à possibilidade de crítica, assim como minou mais ainda o campo propício a ela: o público.

10 O termo "midcentury" não possui tradução em português e se refere a uma estética que imperou e é comum a muitos campos da produção material entre os anos 50 e 70 . O termo é usado para designar principalmente produtos de design. 


\section{CASA DE MÓVEIS LAFER - HISTÓRIA E LEGADO}

Não há como traçar uma trajetória dos anos de criação e produção de Percival Lafer sem recorrer ao histórico de atuação de sua família. A industrialização e crescimento da grande empresa fundada pelo designer só foi possível por meio da base comercial lançada pelo pai. O período de consolidação do comércio moveleiro foi fundante para a atuação de Lafer, no que tange à difusão e venda de seu mobiliário.

Percival não ficou restrito ao problema do escoamento de sua produção. Ele já possuía os meios comerciais, bem como a estrutura básica para iniciar a fabricação de móveis em pequena escala. Valendo-se da organização comercial em rede pré-existente, o designer organizou muito bem a distribuição de suas peças, barreira encontrada pela maior parte dos produtores nacionais entre os anos 50 e 70. A ampla rede de fornecedores e representantes foi usada para difundir a produção de móveis modernos desenhados e fabricados pelo designer. Ele usou aqueles que visitavam o comércio familiar para vender seus produtos como ponte para chegar a outros comerciantes de móveis. Essa tática foi usada inteligentemente para comercializar seus primeiros móveis.

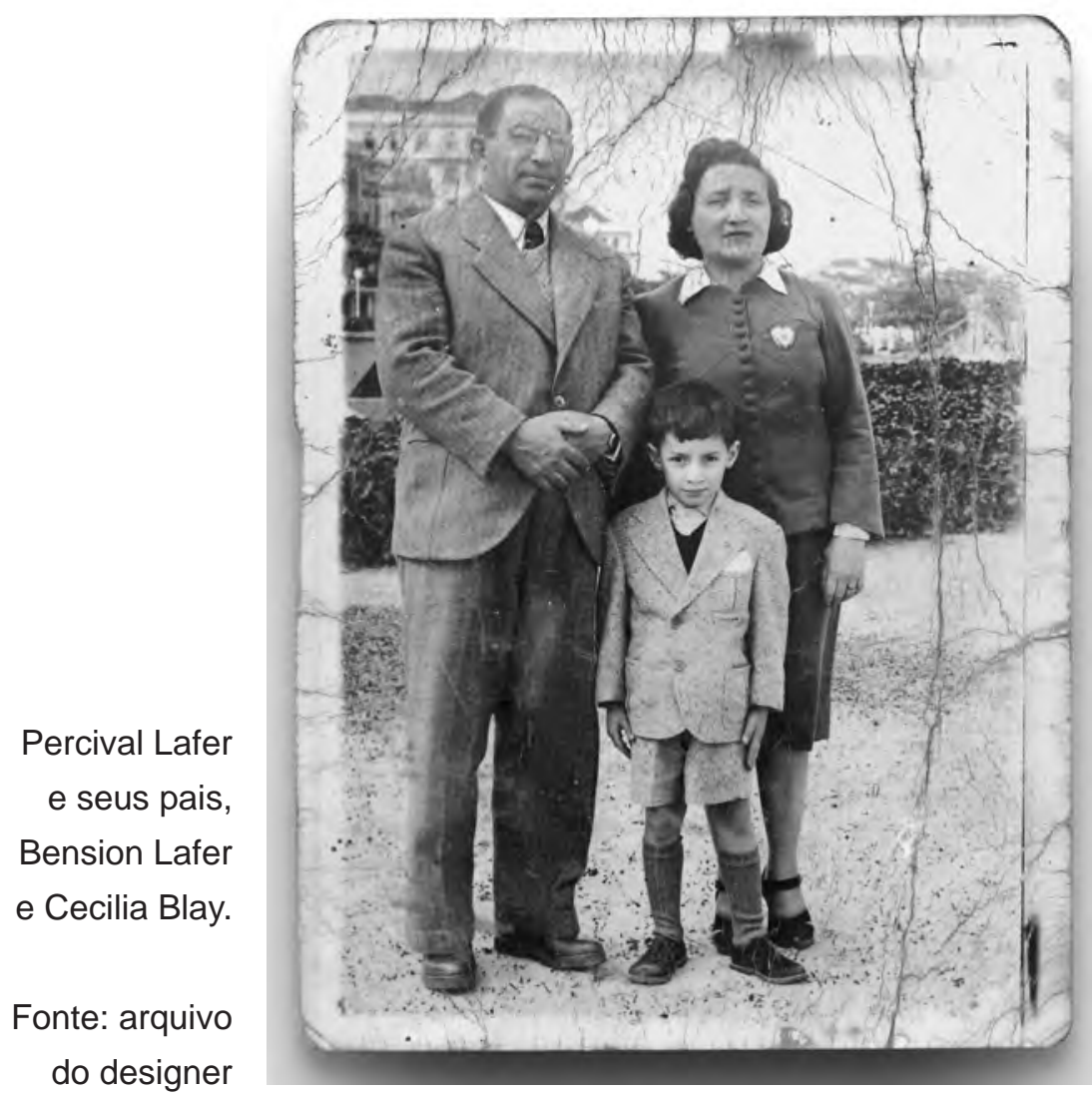


A lógica comercial e o relacionamento com os diversos setores que a compõe delimitaram e conduziram o pensamento do designer. As instâncias de projeto, seriação mecanização, investimento em tecnologia eram indissociáveis do pensamento de vendas, sendo em muitos momentos, senão em sua totalidade, moldadas e adaptadas por ele. A lógica comercial alimentou o designer para pensar as outras consoantes.

Percival é o quarto filho de uma família de imigrantes judeus. O pai, comerciante, Bension Laufer (o nome será abrasileirado para Benjamim Lafer), aporta no Brasil em 1922, vindo da pequena cidade austríaca de Lendorf. Estabelecido numa pensão do bairro do Bom Retiro, Bension começou a trabalhar como vendedor ambulante, oferecendo, de porta em porta, conjuntos de móveis produzidos localmente. A mãe, Cecilia Blay, chega em 1924, imigrada da Ucrânia, Estado que na época havia sido recém ligado à União Soviética, após a Guerra Civil Russa de 22. Em 1927, a família se estabelece na Rua Lavapés, onde Bension inaugura uma pequena loja de móveis, passando a morar num sobrado pegado à loja. A mudança para o bairro do Cambuci, baixada do Glicério, a despeito da ocupação judia ocorrida no Bom Retiro, é estratégica. Grande parte das marcenarias e pequenas manufaturas moveleiras estavam localizadas no município de São Bernardo do Campo. Era favorável para o comércio estar estabelecido em área central, ao mesmo tempo que próximo da maioria dos fornecedores.

O crescimento dos Móveis Lafer dependeu, em grande parte, da aplicação dos conhecimentos comerciais e experiências de Bension. $O$ comerciante criou uma rede de troca entre fornecedores e representantes comerciais, transformando assim o estabelecimento em um entreposto comercial que escoava um certo tipo de produção moveleira. Ele passou a ter seus próprios vendedores ambulantes e investiu na consolidação da loja como uma referência na venda de móveis. Os maiores clientes pertenciam à classe media paulistana, que procurava decorar as casas com peças de estilo aburguesado. Conjuntos de quarto, sala, jantar de desenho "provençal", decô e pastiche eram vendidos pela Lafer, atendendo ao gosto da época.

Com o crescimento dos negócios, já na década de 40, Bension tentou lançar-se no campo da fabricação. Investe então na compra dos imóveis vizinhos à loja no Cambuci, e constrói um pequeno galpão para abrigar uma série de maquinários básicos de marcenaria, serralheria e 
Publicidade aplicada em antigo prédio da família, 1961. Nota-se a veiculação da imagem da primeira poltrona de Percival, a MP1

Fonte: arquivo do designer

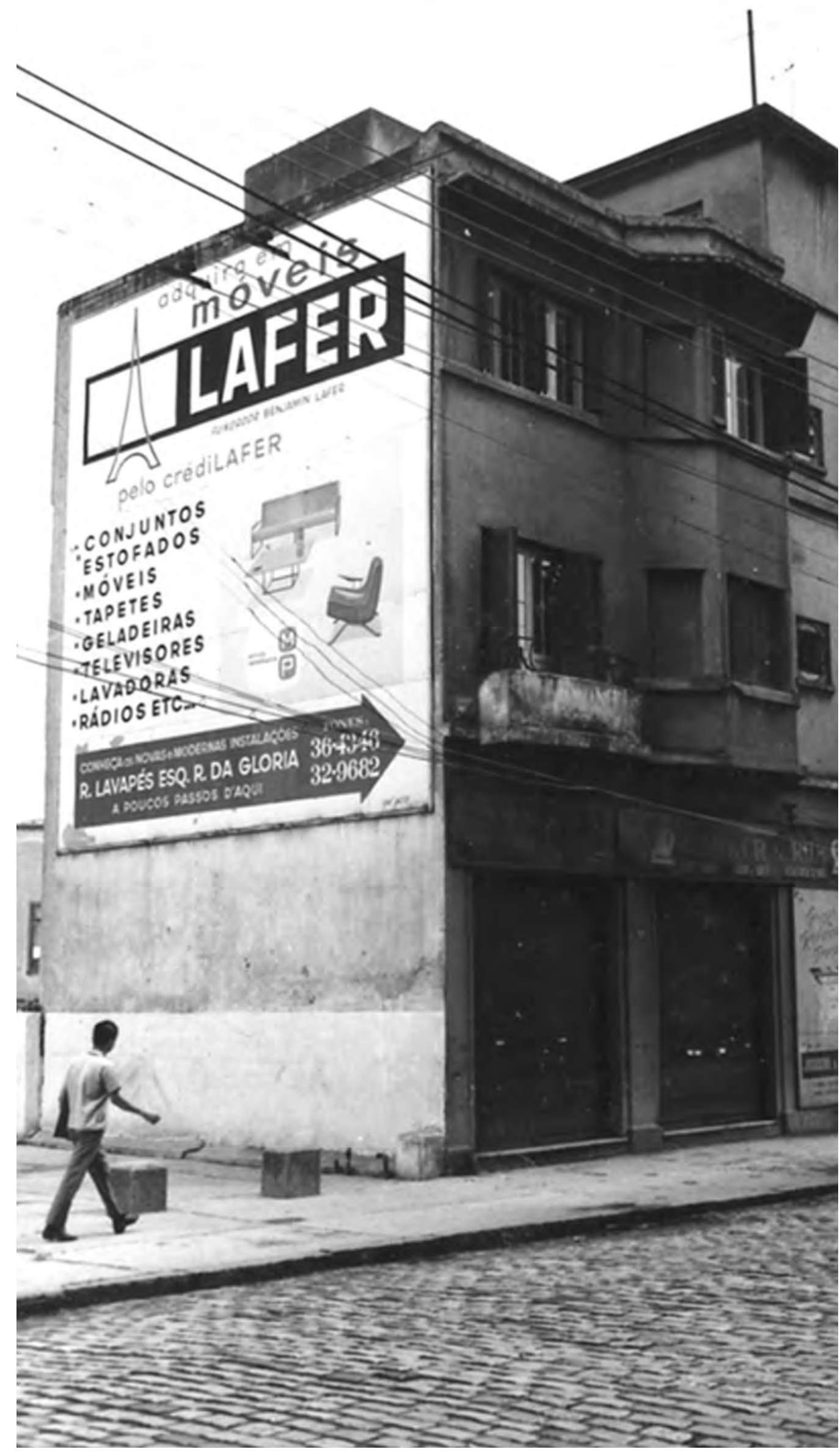


estofamento. A ideia era reproduzir os móveis de mercado que ele mesmo vendia, começando por conjuntos de quarto e estofados. No entanto, a experiência não foi além disso. A falta de conhecimento técnico dificultava a absorção das demandas específicas ao campo da produção e da venda. Percebendo que sozinho não conseguiria avançar, Bension desiste de sua incursão no terreno da manufatura. Quando Percival começou sua carreira profissional, a loja Casa de Móveis Lafer, já existia há 34 anos. 0 pai já havia desistido de sua empreitada no campo produtivo, mantendo-se apenas no setor comercial. Ainda sob o comando de Bension, durante os anos de estudo, o designer chegou a desenhar projetos de mobiliário sob medida para clientes especiais, produzidos por terceiros, nada além disso.

Em 1961, Bension Lafer falece. Percival, juntamente com seus irmãos, Samuel e Oscar, e o cunhado, José Portenoy, se deparam com a necessidade de continuar os negócios legados pelo patriarca, mas agora de outra forma. As tarefas são divididas e Percival fica a cargo de repensar os produtos e estratégias de venda. Livre de obrigações administrativas, o designer se lança em um processo de criação e reativa a pequena fabriqueta, montada anos antes pelo pai. O investimento inicial feito em máquinas foi crucial para que Percival pudesse colocar em prática a produção dos primeiros móveis em estilo moderno, durante a empreitada de modernização e reorganização da empresa familiar.
Antigo Prédio residencial da Família Lafer, localizado no bairro do Cambuci, em São Paulo.

O térreo era alugado para um dos fabricantes que forneciam para Bension.

Fonte: arquivo do designer
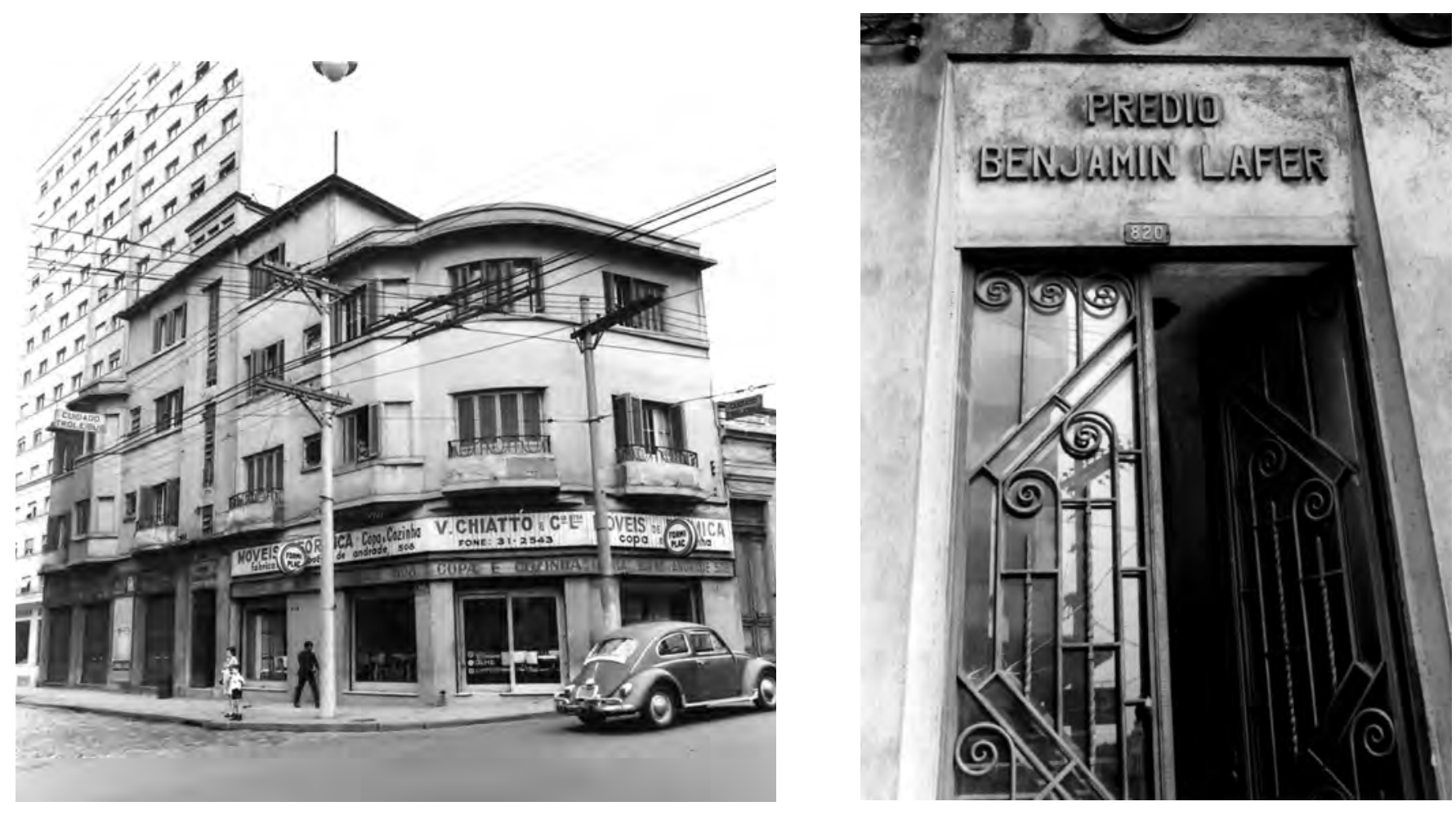
O primeiro passo foi a modernização da arquitetura da loja. Logo após da Casa de Móveis Lafer ganhar nova roupagem, produtos modernos passaram a ser vendidos paulatinamente, em paralelo a produção dos primeiros móveis produzidos pelo designer. O investimento crescente em publicidade ajudou na difusão do nome da empresa e em sua consolidação no mercado enquanto referência. A conscientização da importância da publicidade virá somente com a criação no sofá cama MP7, em 1965.

A Móveis Lafer, novo nome dado nesse período, passou a vender grandes nomes do mobiliário brasileiro, como Jean Gillon, Michel Arnoult e Jorge Zalszupin, além de réplicas e uma produção independente que ficou anônima. (ver foto). Os produtos em estilos antigos deixaram de ser comercializados. $\mathrm{O}$ foco era atender uma crescente população que, com o advento de Brasília, passou a entender a boa arquitetura e o bom design como modernos. A representação e mudança do tipo de produto vendido pela loja serviu para inserir os desenhos de Percival, que agora eram vendidos lado a lado com o que havia de mais atual na época. Dessa forma, Percival preparou o caminho para a sua inserção no mercado.

Já no final dos anos 60 , com a variedade de produtos oferecidos pela própria Lafer, a marca MP LAFER, de Móveis Patenteados Lafer, é consolidada e passa a comercializar apenas peças próprias. A ideia, desde o início, com a fabricação da primeira poltrona, a MP1, era produzir móveis de extrema qualidade em série. "As peças teriam tanto sucesso que precisariam de patentes para serem protegidas das cópias", conta o designer sobre a origem do nome. Ele continua "... [desde a MP1], cada peça recebia uma etiqueta com as siglas MP e o número da poltrona". Os móveis foram patenteados por diversos agentes, sendo o escritório Britânia Marcas e Patentes, de Luis Ortega, amigo do designer, o mais importante. Hoje, Percival requer patentes apenas dos mecanismos. "Mais efetivo que o só a proteção do design", afirma.

Os novos produtos eram expostos em ambientes decorados. Essa tendência inovadora era uma estratégia comercial desde os anos 50 . Com a crescente introdução da publicidade de massa no país e a fortificação das dinâmicas impostas pela indústria cultural, a ambientação da loja passou a ser ferramenta fundamental para as vendas de mobiliário. $\mathrm{O}$ cliente encontrava soluções integrais, com possibilidades e promessas de individualização. Do móvel, iluminação e acessórios, era possível enxergar como as peças poderiam se comportar em conjunto. 
Vista da fachada da loja de móveis Lafer, localizada na Rua Lavapés, no bairro do Cambuci.

Fonte: arquivo do designer

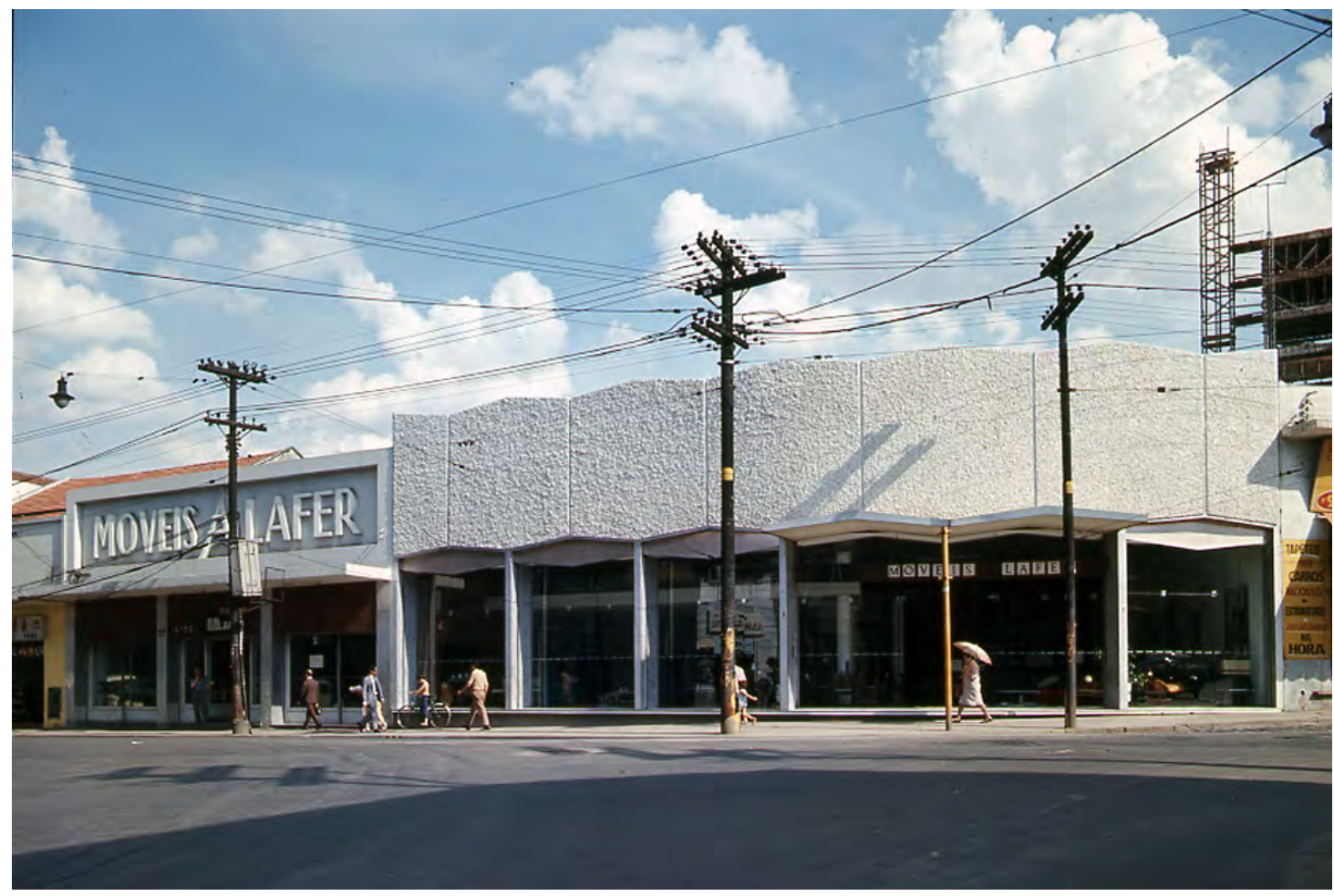

Percival e um vendedor no interior da loja. Com a modernização do comércio, o designer passou a vender móveis de estilo modernista.

Fonte: arquivo do designer

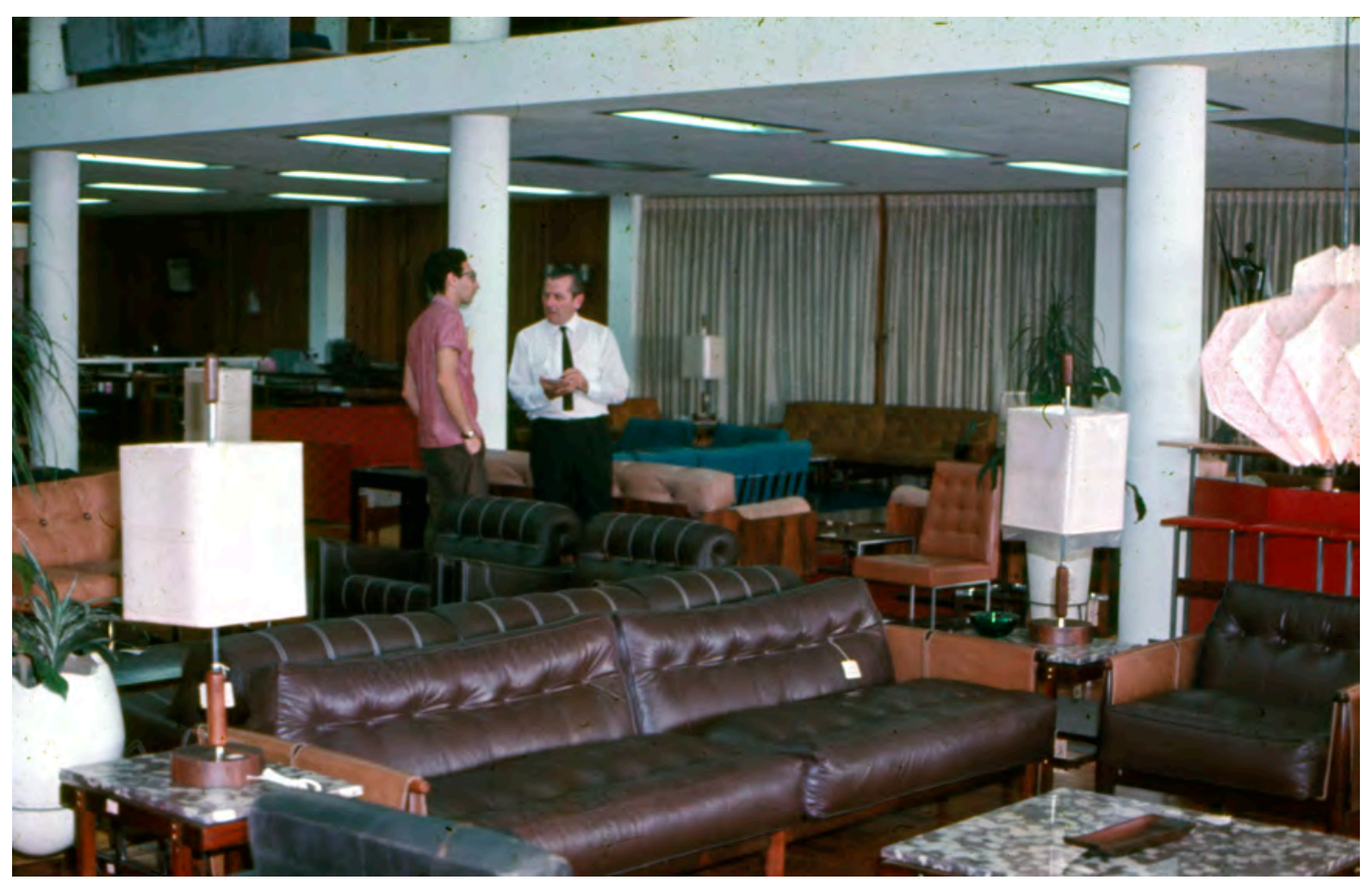


Percival usou sua rede de fornecedores, que traziam móveis de terceiros para serem vendidos na loja, como rede de representantes. $\mathrm{O}$ designer passou a oferecer os seus produtos a outros pontos comerciais por meio desses profissionais. Foi assim com sua primeira poltrona. A estratégia foi um sucesso e diversas lojas de móveis na época passaram a comercializar os produtos produzidos pelas Móveis Lafer. Desde então, a venda foi e é, até hoje, realizada em pontos de venda próprios e de terceiros. Esse dado explica a permeabilidade que os produtos Lafer tiveram no mercado nacional durante tanto tempo. Falaremos ainda sobre essa trajetória nos subcapítulos.

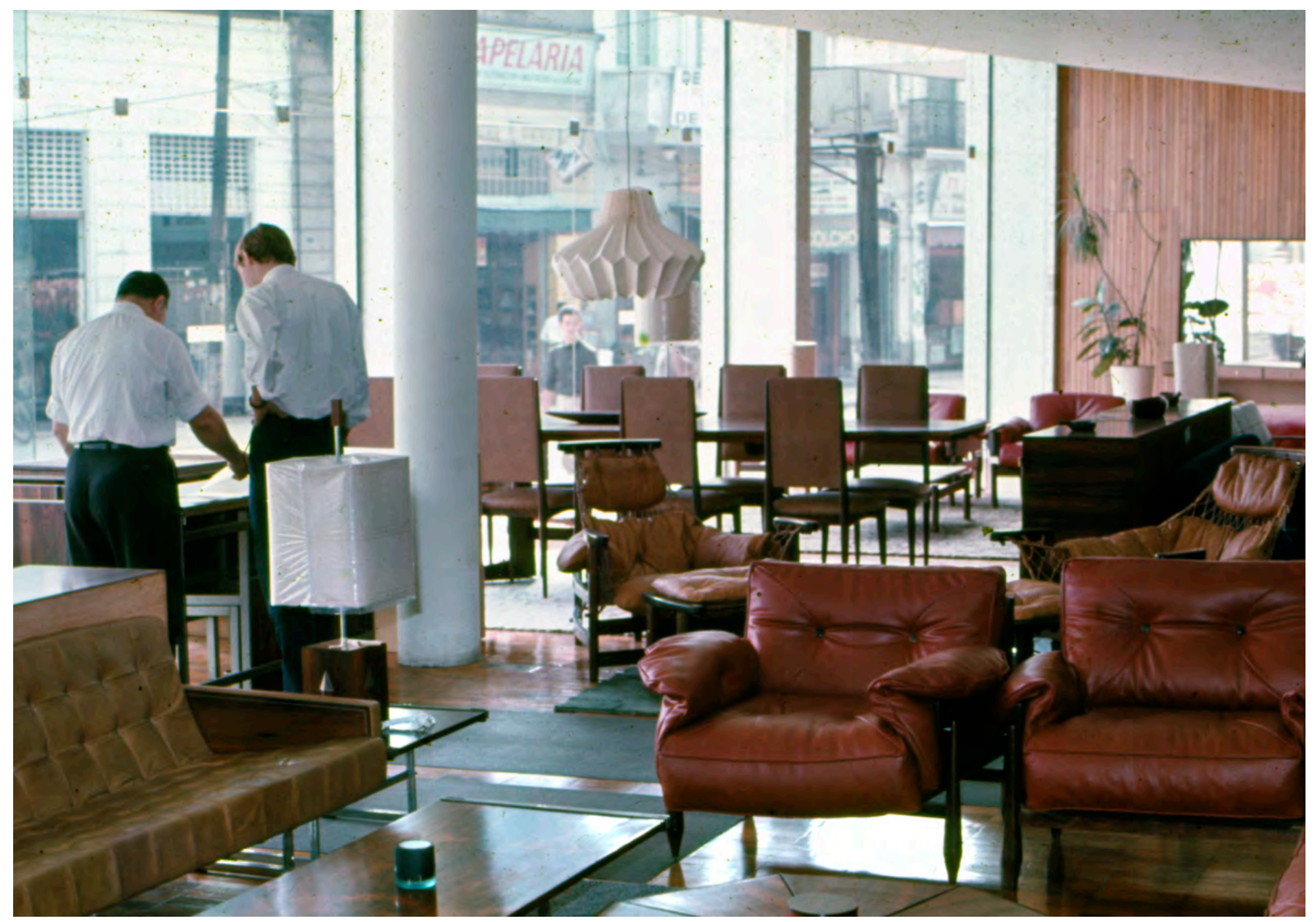

Interior da loja de Móveis Lafer no ano de 1962. Observa-se que juntamente com suas produções, como é o caso do sofá MP9 em couro caramelo, a esquerda, Percival comercializava móveis de outros designers. $\mathrm{Na}$ foto, podemos identificar as poltronas Jangada, dfe Jean Gillon; dus poltronas Pistão de Jorge Zalszupin, e a mesa Pétala, do mesmo autor. Fonte: arquivo do designer 


\title{
OS ANOS DE FORMAÇÃO E PRIMEIRAS EXPERIÊNCIAS
}

\author{
Assim como a grande maioria dos designers modernos, Percival Lafer \\ cursou arquitetura ${ }^{11}$. Em 1954, ingressou na Faculdade de Arquitetura e \\ Urbanismo da Universidade Mackenzie. Nessa época a instituição era \\ dirigida por Christiano Stockler das Neves e mantinha uma grade curricular \\ de ensino da arquitetura inspirada no modelo da École de Beaux Arts \\ de Paris $^{12}$. No entanto não foi esse ambiente que influenciou Lafer, já
}

11 O ensino de desenho industrial estava apenas começando a ser implementado no Brasil. Sobre as primeiras experiências formativas no campo do Desenho Industrial, Maria Cecilia Loschiavo dos Santos escreve: "em 1950, o Museu de Arte de São Paulo (MASP) criou e abriu as inscrições para o Instituto de Arte Contemporânea (IAC), escola de design dirigida pela arquiteta Lina Bo Bardi, reunindo experientes professores, tais como: Lasar Segall, Thomas Farkas, Roberto Sambonet, Jacob Ruchti, dentre outros. Foi uma iniciativa pioneira no âmbito do ensino do design, propiciando ao público interessado as necessárias especificidades e habilidades para a formaçã da nova loja de de Michel Arnoult Na rua Vieira de Carvalho no ano de 19 tarde, no ano de 1953. pioneira no contaminados undado da nova loja de de Michel Arnoult Na rua Vieira de Carvalho no ano de 19 tarde, no ano de 1953. pioneira no contaminados undadoo. [...] Ainda ressaltando a função educativa dos museus no âmbito da promoção do design, no ano de 1956, no Rio de Janeiro, foi criada a Escola Técnica de Criação do Museu de Arte Moderna (MAM) do Rio de Janeiro, embrião da primeira escola de nível superior, a Escola Superior de Desenho Industrial (ESDI), criada mais tarde, no ano de 1953." SANTOS, Maria Cecília Loschiavo dos. Jorge Zalszupin - Design moderno no Brasil. São Paulo: Olhares, 2014 p.24.

12 "Para os arquitetos acadêmicos vinculados a esse modelo, como Neves, a arquitetura é uma disciplina eminentemente artística, que tem como objetivo principal atingir a beleza pela recuperação das formas que a história da arquitetura consagra a cada tipologia. Interessa a esses arquitetos não a originalidade ou o ineditismo de seu projeto, mas o perfeito conhecimento da tipologia e dos estilos a ela vinculados, e a sua adaptação às necessidades da época. Daí a importância que as disciplinas de desenho à mão livre, história, teoria, elementos da arquitetura e composição têm no curso proposto pelo Mackenzie, oficializado em 1917, inicialmente como um departamento da Escola de Engenharia e, a partir de 1947, como uma Faculdade de Arquitetura independente. A orientação de ensino da faculdade e a valorização de estilos vinculados à tradição clássica, como o Renascimento e o neoclassicismo francês - nomeados pelo arquiteto como 'Luís XVI modernizado' -, estão presentes nos projetos desenvolvidos entre os anos 1912 e 1940, e na série de artigos publicados em revistas especializadas como a 'Architectura e Construções' e nos jornais 'O Correio Paulistano', 'O Estado de S. Paulo' e 'O Diário', este último do Rio de Janeiro. Nesses artigos, o estilo Luís XVI modernizado é defendido por Neves como o símbolo de civilização e progresso a ser adotado pela nação, em crítica à a campanha de arte tradicional liderada por Ricardo Severo (1869 - 1940), em São Paulo, e José Marianno Filho (1881 - 1946), no Rio de Janeiro, por considerar a arquitetura colonial uma manifestação artística de pouco ou nenhum valor. Em outro conjunto de artigos, Neves se contrapõe aos preceitos básicos do movimento moderno, afirmando que os projetos "futuristas" de Frank Lloyd Wright (1867 - 1959), Le Corbusier (1887 - 1965), Gregori Warchavchik (1896 - 1972), Lucio Costa (1902 - 1998), entre outros, por se aterem apenas à utilidade, funcionalidade e estandardização da construção, não podem ser 
que nessa mesma época a transição para um ensino técnico-científico voltado para os ideias modernistas era implementado com a pressão crescente dos próprios alunos do Mackenzie. A troca com os alunos da Faculdade de Arquitetura e Urbanismo da Universidade de São Paulo (FAU-USP), escola que disseminava os ideais modernistas, era grande. Muitos de seus colegas estudavam na FAU-USP, na época, localizada na Vila Penteado, Rua Maranhão, no bairro de Higienópolis, há apenas uma quadra da unidade do Mackenzie.

As discussões sobre arquitetura moderna eram tema da época. Brasília estava em construção e a figura de Oscar Niemeyer era o modelo a ser seguido. Os arredores da faculdade estavam povoados, como ainda hoje, de escritórios de arquitetura. A rua General Jardim já fervilhava em um vai e vem de profissionais da área, enquanto mais abaixo, em direção ao Largo do Arouche, estavam instaladas todas as grandes marcas de mobiliário moderno da época. Sobre a instalação da nova loja de Michel Arnoult, Mobília Contemporânea, na rua Vieira de Carvalho, no ano de 1955, Ethel Leon relata:

“De 1951 a 1957, essa região da cidade passou a abrigar vários arquitetos, editores e empresários do móvel moderno. A Galeria Ambiente, de Léo Seincman, foi aberta em 1951 na rua Martins Fontes e apresentava, ao público paulistano, os móveis de Alvar Aalto, Giancarlo Palanti, Lina Bo Bardi, Roberto Aflalo, Eduardo Corona, ente outros, ao lado de obras de artistas plásticos modernos. Os arquitetos da Branco e Preto, Carlos Millan, Jacob Ruchti, Miguel Forte, Plinio Croce e Roberto Aflalo, inauguraram seu espaço comercial na rua Vieira de Carvalho, em dezembro de 1952. Em 1953, o já conhecido designer Joaquim Tenreiro

\footnotetext{
considerados propriamente arquitetura. Antimodernista convicto, Neves trava uma verdadeira batalha contra esses arquitetos dentro e fora da faculdade, tendo como interlocutores, além dos arquitetos já citados, os escritores Oswald de Andrade (1890 1954) e Mário de Andrade (1893 - 1945) e, sobretudo, seus alunos, entre eles Eduardo Kneese de Mello (1906 - 1994), Oswaldo Bratke (1907 - 1997), Miguel Forte (1915 - 2002), Salvador Candia (1924 - 1991), Carlos Lemos (1925), Carlos Millan (1927 1964) e Paulo Mendes da Rocha (1928), que juntamente com os professores adeptos do movimento moderno conseguem afastá-lo do cargo em 1957." CHRISTIANO Stockler das Neves. In: ENCICLOPÉDIA Itaú Cultural de Arte e Cultura Brasileiras. São Paulo: Itaú Cultural, 2018. Disponível em: <http://enciclopedia.itaucultural.org.br/ pessoa443402/christiano-stockler-das-neves>. Acesso em: 18 de Jan. 2018. Verbete da Enciclopédia. ISBN: 978-85-7979-060-7
} 
decidiu instalar a filial de sua loja carioca na rua Marquês de Itu, também no centro de São Paulo. No mesmo ano foi inaugurada a Galeria Artesanal na rua Barão de Itapetininga. E a cooperativa de móveis modernos Unilabor abriu sua primeira loja na praça da República em 1957."13

Assim, podemos entender a agitação dos locais que Lafer frequentava e como eles tiveram influência sobre a cabeça do jovem estudante. Desenho industrial era sinônimo de produção em série, e a discussão sobre o móvel moderno e a necessidade de coerência entre o projeto e as diversas variáveis da produção industrial estavam em alta. No entanto, até então, nenhum designer havia conseguido colocar em prática uma seriação de móveis, com exceção das experiências das fábricas do sul do país, como a 'Móveis Cimo', 'Móveis Miele', 'Gerdau', 'Patente' e outras. A falta de tecnologia, mão de obra, fornecimento de insumos, dentre outras questões, minaram muitas das tentativas de se criar uma produção seriada brasileira de móveis. Muitos arquitetos e designers da época produziram em baixa escala, dentro de uma lógica artesanal de manufatura e, principalmente, de pensamento de projeto.

Quando falamos de produção industrial, nos referimos ao pensamento industrial do projeto. Poucos foram os casos em que as instâncias da concepção e da fabricação casavam em uma perfeita linha de produção industrial. Os que mais próximos chegaram dessa completude projetual e produtiva, não se atendo a números, foram Lina Bo Bardi, com as experiências do 'Studio de Arte Palma' e a empresa 'Pau Brasil Ltda.', Geraldo de Barros, com a 'Unilabor', e Michel Arnoult, com a 'Mobília Contemporânea'. A maioria dos outros mantiveram um pensamento artesanal de projeto e de beneficiamento material complicado, principalmente da madeira.

É interessante notar o uso primário e inaugural de materiais metálicos. Se observarmos as primeiras experiências de Lina Bo e Geraldo de Barros, perceberemos que ambos recorreram ao metal. Essa não é uma escolha ingênua, e para além da influência do desenho da Bauhaus ${ }^{14}$, configura a exploração e a partida mais acertada para 
se iniciar uma produção industrial. Enquanto a madeira requer muitas etapas de beneficiamento, além de um domínio técnico e maquinário específico e caro, o metal apresenta etapas de transformação reduzidas. A disponibilidade de peças metálicas pré-fabricadas é grande, e sua mão de obra mais difundida. Michel Arnoult, ao contrário, muito familiarizado com a linguagem e estratégia industrial, profundo conhecedor da seriação, trabalhou magistralmente com a madeira logo de partida.

É importante lembrar que quando Percival entra no mercado, arquitetos e designers da década anterior já haviam disseminado o ideário modernista a grande parte da classe média consumidora brasileira. Nesse aspecto, a construção de Brasília foi de suma importância. Se na década de 1950 apenas as classes mais esclarecidas consumiam produtos ditos modernos, a partir da década de 1960, a mentalidade começou a mudar, sobretudo, devido às transformações da ordem mundial e à expansão do capitalismo, representados pela disseminação da televisão, da Indústria Cultural e da moda, e aos avanços tecnológicos e científicos. Neste contexto, uma parte da população brasileira começou a comprar o móvel moderno. Sobre as décadas de 40 e 50, Pietro Maria Bardi, marido e sócio de Lina na 'Pau Brasil Ltda', relata que "[...] a mentalidade era tão antimoderna! O que predominava eram os móveis de Paschoal Bianco e do pessoal do Brás." 15

influenciou o modernismo brasileiro, em especial pelo contato com Le Corbusier, utilizaram prolificamente perfis e componentes metálicos no desenho de seu mobiliário. Neste contexto, o metal encarnou o símbolo do modernismo, mecanização, impessoalidade e leveza dos novos meios de vida, entre outros tantos fatores que merecem um estudo aprofundado. No caso brasileiro, a escolha de perfilados metálicos na fabricação do mobiliário ganha outra dimensão, geralmente relacionada à urgência de produção. O Brasil possui uma intimidade histórica com a madeira. No entanto, não possuía conhecimento e maquinário suficiente para industrializar um desenho para tal material, que até então era trabalhado artesanalmente. A serralheria ocupa assim um lugar de primazia nas experiências iniciais de muitos designers, sendo uma técnica usada, até hoje, por sua versatilidade, baixo custo de execução e mão de obra disponível. É mais fácil produzir em metal. A madeira continua sendo um insumo caro e ligado ao mercado de luxo. (N.d.A)

15 A mentalidade em pleno século XXI continua antimoderna. Embora quase todas as marcas de móveis modernos tenham falido e sua produção tenha ficado reduzida à reedições de luxo, artesanais e para a classe altíssima, contrárias a todo ideal modernista, a Paschoal Bianco continua, desde 1892 (o fim da escravidão foi "declarada" em 1988 e 
Percival lança sua primeira peça em metal. A poltrona MP1 é desenhada e produzida em 1961. Antes disso, o designer havia experimentado a pequena fabriqueta montada pelo pai para produzir alguns móveis sob medida para clientes especiais. Todas as primeiras experiências do designer foram fabricadas a partir desse primeiro desenho. A produção em larga escala era inerente a concepção da MP1. Não sabemos quantos exemplares de poltronas e sofás dessa linha foram produzidos. No entanto, foi a partir desse modelo, que Percival se lançou no mercado - vendendo em sua própria loja e para representantes. O móvel, de linhas leves, com o estilo difundido na época e sem novidades formais, agradou os compradores. A inovação do conjunto de sala MP1 se encontra nas técnicas empregadas. Novas soluções produtivas foram adotadas: o uso de percintas ao invés de molas e outros tipos de estofado, a pintura eletrostática a pó, a colagem do tecido sobre a espuma, o revestimento decorativo de madeira sobre estrutura metálica. Após o lançamento desse conjunto de sala, outras séries foram pensadas, a partir da mesma base produtiva.

Em 1965, Percival dá um salto, e produz o MP7. O sofá cama "automático" foi um marco para a MP LAFER. O objetivo de seu lançamento era acompanhar o discurso político de mecanização e desenvolvimento produtivo do país, e aproveitar as iniciativas de subsídio à exportação de produtos industrializados, formulado pelo governo da ditadura.

Data deste mesmo período, a compreensão de que, na inaugural era do espetáculo, aparecer era uma urgência de primeira necessidade. Assim, foram feitas parcerias com outras empresas, no intuito de investir em publicidade. Os anúncios impressos, bem como a campanha por trás deles, eram pagos conjuntamente com fornecedores de insumos da Lafer, como era o caso da 'Perilan' e da 'Trorion'. Na publicidade impressa do MP15, podemos observar como essa fusão era realizada estrategicamente. Os custos eram divididos, enquanto as vantagens de uma e outra fortificavam a imagem das partes envolvidas.

A partir de então, o estímulo direcionado ao consumidor passou a ser

estamos em 2018), fornecendo móveis de estilo à classe média, a mesma que, segundo Lina (talvez a única moderna com autoridade para falar isso), é afeita aos "[...] móveis do Baú da Felicidade". Esse dado, embora anedótico, sobretudo no contexto de desigualdade e miséria do Brasil, nos faz pensar na falência do moderno, seu impacto e significado social. BARDI, 1980 apud. SANTOS, 2015, op. Cit., p 139. (N.d. A.) 
Estande Lafer na Feira da UD 1964. Fonte: arquivo do designer

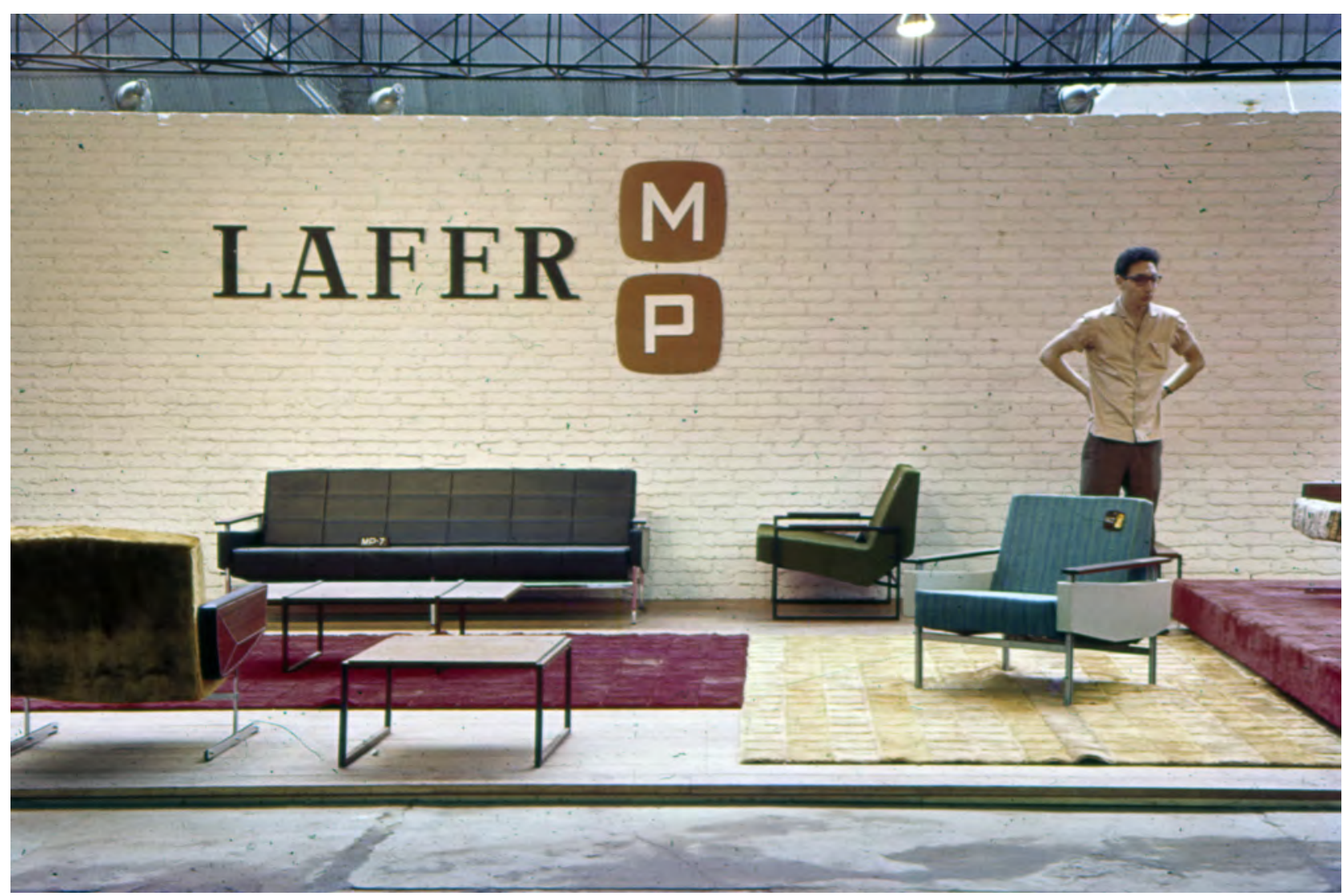

Estande Lafer na Feira da UD 1964. Fonte: arquivo do designer

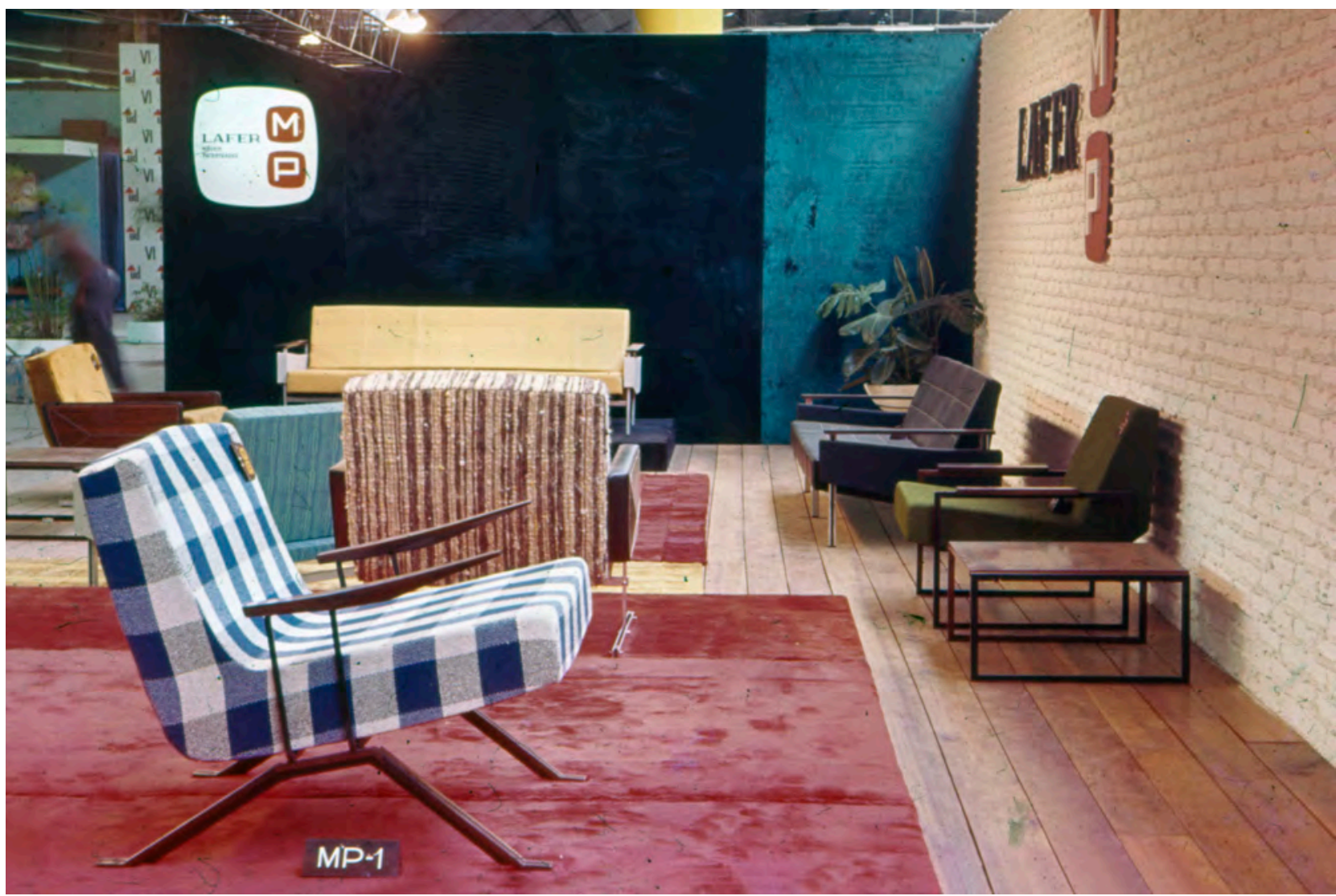




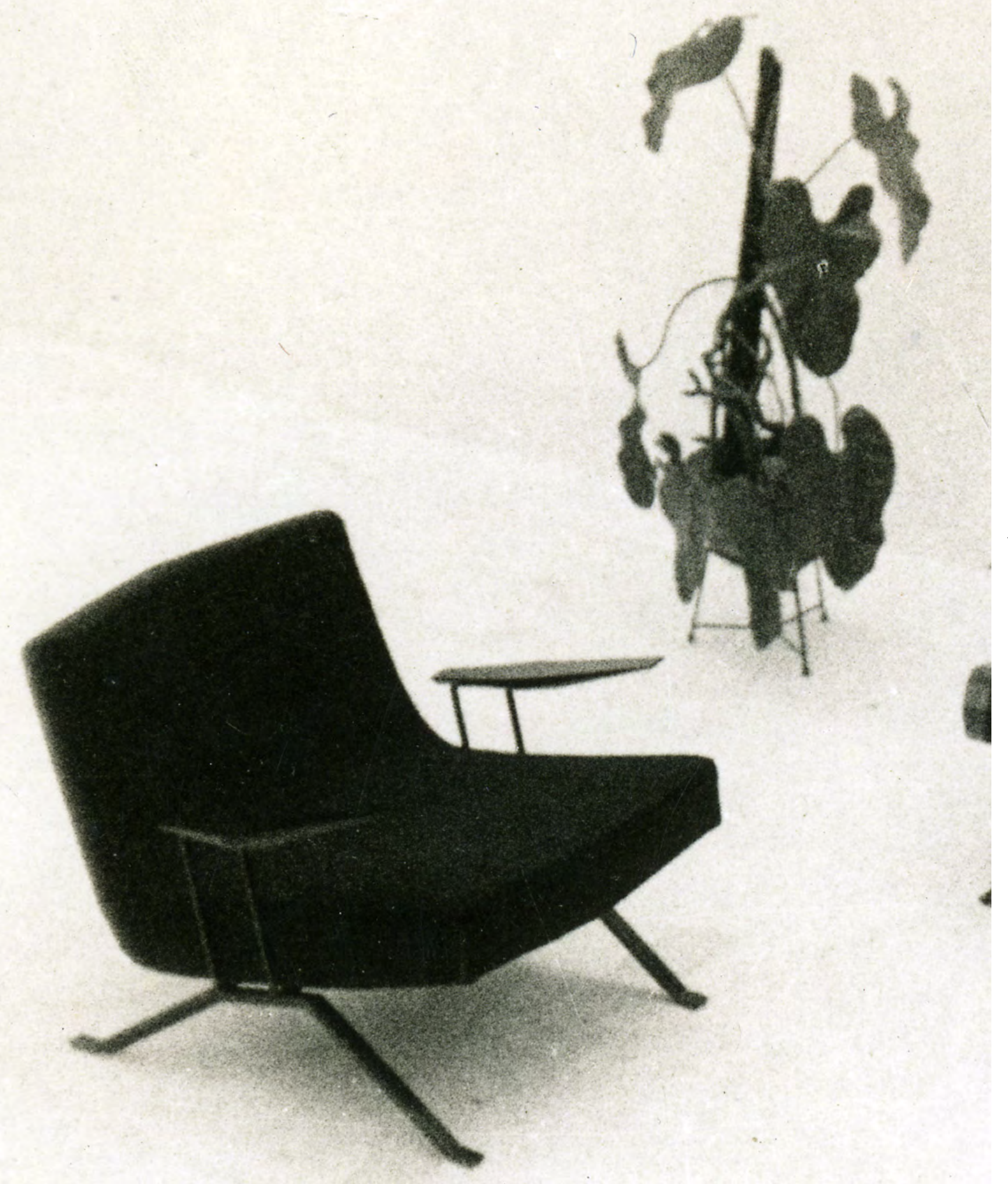




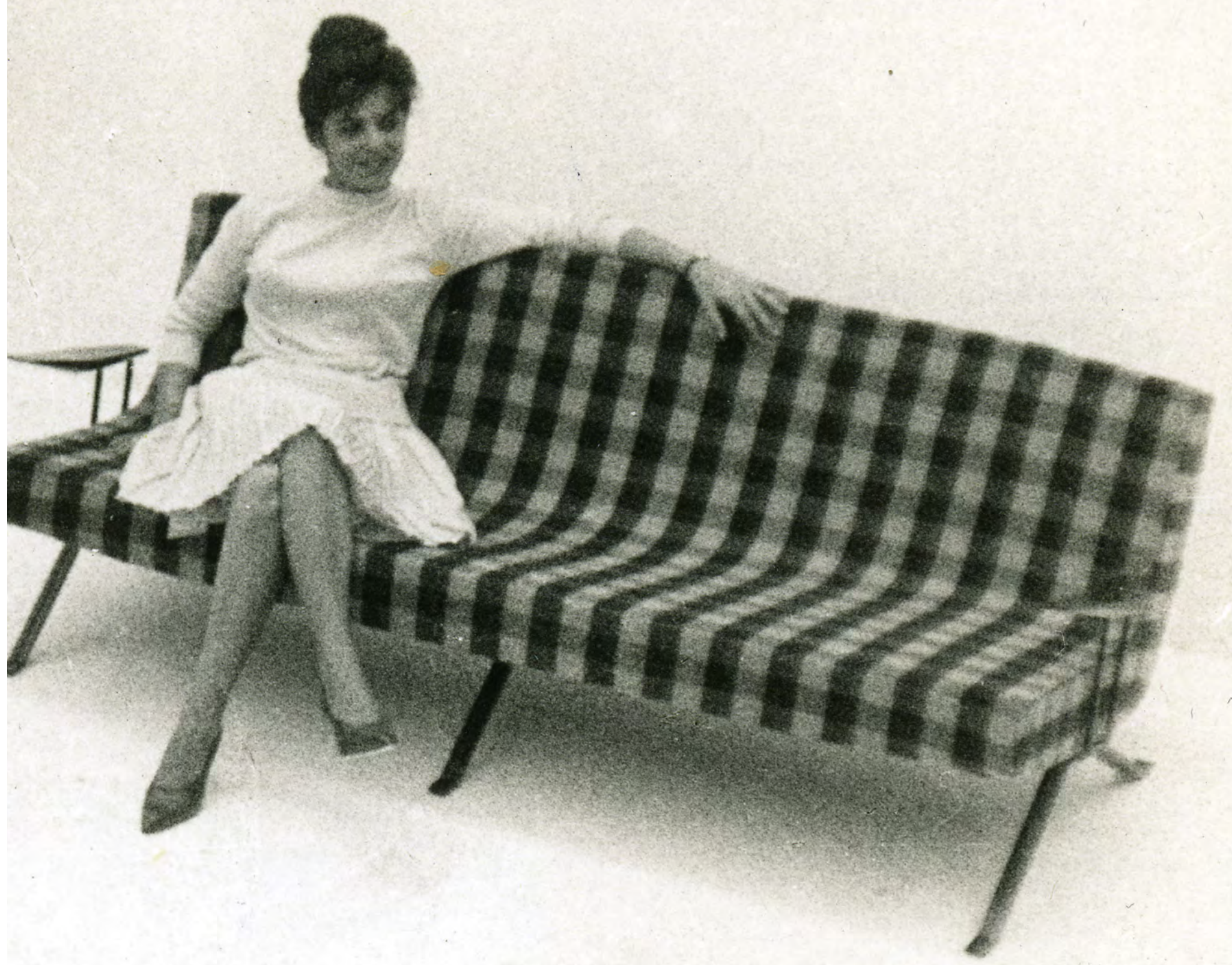

Conjunto MP1 sendo fotografado para publicidade .Fonte: arquivo do designer 
regido pela publicidade pensada internamente na empresa de Lafer. Por meio da proximidade com o cliente e da lógica do gosto, muitas vezes, o designer submeteu seu desenho ao agrado e aceitação popular das vendas. Isso fica evidente nas linhas de móveis mais baratas, constituídas, na maioria dos casos, por adaptações de peças mais elaboradas, por outras vezes, projetos completamente mercadológicos e destituídos de valor estilístico. A produção dessas peças foram concessões feitas ao mercado. Sobre isso, 0 designer comenta sua percepção sobre a produção de outros profissionais, que mantinham uma coerência formal em sua trajetória, mas não se preocupavam com a seriação industrial, nem com o mercado da massa:

"Eu assistia pessoas com desenho de alto nível, mas eles não tinham essa preocupação de alcance de mercado. $O$ desenho era purista, com a preocupação pelo produto perfeito, mas não se importavam em vender para (sic.) deus e o mundo. Essa é a diferença básica [...], e por conta disso muitas vezes eu fiz concessões [...], e muitas vezes a minha resposta para isso eram desenhos discutíveis em relação a qualidade de desenho. Isso faz parte. Às vezes eu virava a cara para o meu próprio desenho."16

Os desvios foram conscientes e nem sempre agradáveis. Percival lançou desenhos que ele mesmo não gostava para poder suprir o que as tendências ou pesquisas de mercado ditavam, e, com isso, aumentar sua produção. Ao falar sobre o ato criativo, Lafer o define como uma conjunção de muitas variáveis, dentre elas as demandas do mercado. Essa foi a escolha do designer.

16 Depoimento cedido ao autor. São Paulo, 09 de setembro de 2016. 


\section{MP LAFER - CONSOLIDAÇÃO DA MARCA E IMPULSO DOS ANOS DE INDUSTRIALIZAÇÃO}

Em nenhum momento Percival deixou de pensar no aumento e modernização da produção, pois ela corria paralela ao potencial de procura de venda. Os anos de crescimento corresponderam aos anos do "milagre econômico" proposto pela ditadura. A MP Lafer era a única empresa que correspondia, naquele momento, à escala e demanda de consumo de uma classe média crescente e fortificada pelo regime.

O projeto era concebido já levando em consideração todos os fatores mercadológicos e fabris. As peças eram desenhadas em associação direta com o seu modo de produção. Não havia ingenuidade de intenção. $O$ ideal sempre foi a mecanização e a venda em escala. Nesse sentido, houve investimento em tecnologias que respondessem de forma estratégica às necessidades de produção, que, por sua vez, recebia o retorno do mercado.

Percival entendeu, desde muito cedo, que deveria se adequar de forma esponjosa ao mercado. O crescimento estrutural da vida midiatizada, forjada pelo pensamento da moda e da indústria cultural, de grande pluralidade, fetichizada e inconstante foi rapidamente compreendida pelo designer, mesmo que intuitivamente. Ao longo da sua carreira, produziu produtos variados para atender as diversas frentes de demanda. Do artigo de luxo ao cacareco das massas, as linhas eram praticamente apresentadas como coleções, enquanto a publicidade propunha uma caracterização dos afetos da vida, em um movimento de projeção de valores subjetivos aos elementos concretos da cultura material. Não se adquiria simplesmente uma cadeira ou uma poltrona, mas sim um "estilo de vida", uma etiqueta.

A consolidação da marca deveu-se à versatilidade e rapidez com que Lafer respondia ao mercado. Haviam pouquíssimos designers ocupando esse papel. Aqueles que continuaram a criar de forma autoral, restringiram-se ao mercado das elites cultas. Numa época em que só existiam as grandes magazines para o consumo popular, Lafer destacouse na criação de um produto médio que reunia as qualidades do móvel autoral, acessível apenas a uma pequena parcela de consumidores ricos, a um custo benefício razoável. A variedade de produtos Lafer foi vendida por representantes de todo o país. No final dos anos 1970, a empresa 


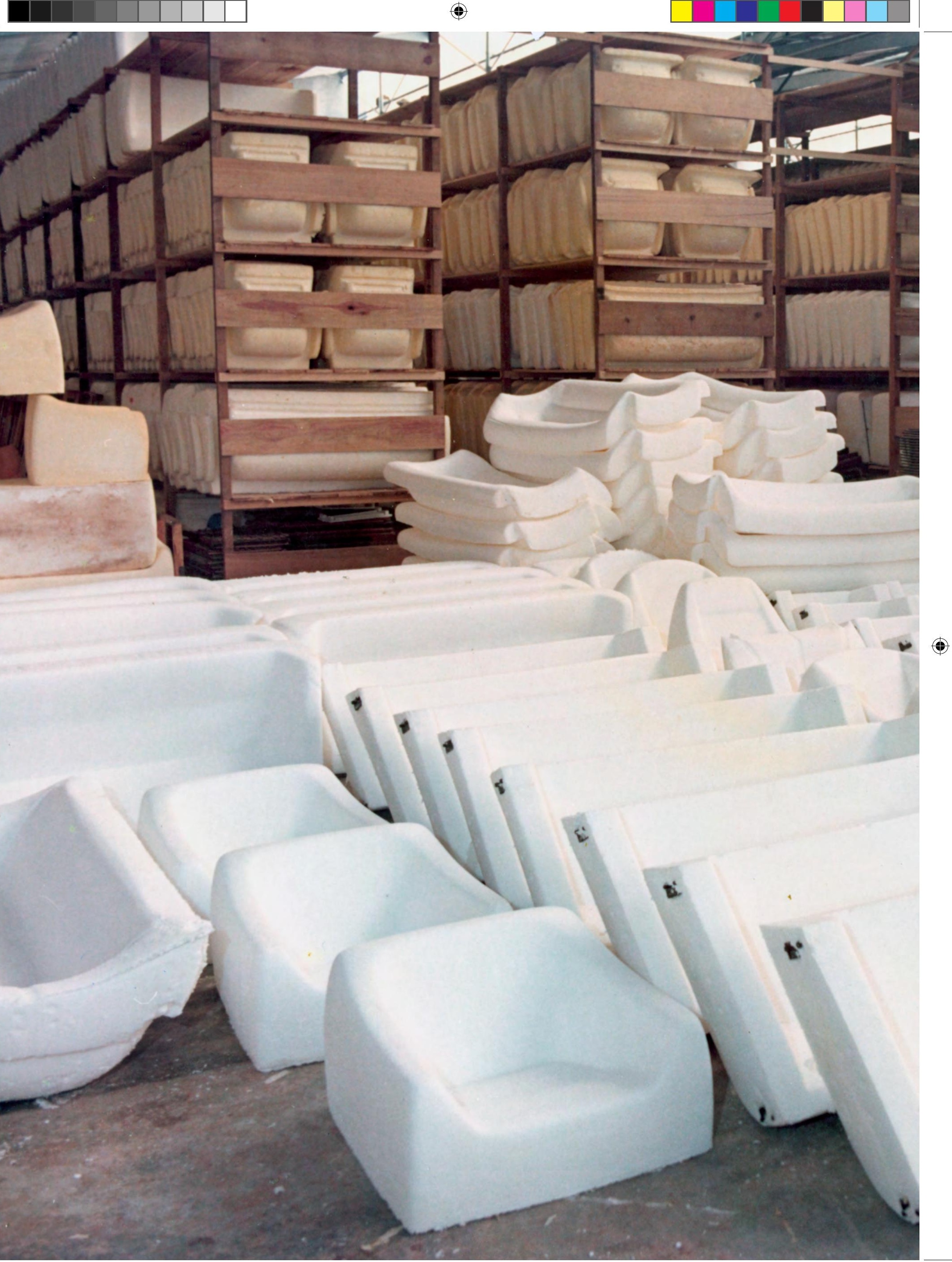


chegou a mudar o nome de suas lojas para 'Interdomus Lafer'. Uma clara estratégia de marketing para não concorrer com a grande quantidade de representantes e para não canibalizar as próprias políticas de venda por atacado e varejo. As lojas eram concebidas pelo próprio designer. A mais importante ocupava um prédio inteiro de 8 andares projetado por Percival e localizado na avenida Faria Lima.

No campo da produção, a fábrica seguia um modelo setorizado fordista adaptado à precariedade nacional. Cada produto exigia uma certa adequação da cadeia produtiva, da mão de obra e das tecnologias empregadas. Em 1968, sete anos após o lançamento da primeira poltrona, o parque industrial, instalado num galpão de 5.000m2 na Via Anchieta, chegou a empregar mais de 2000 funcionários. ${ }^{17}$ Composta por núcleos operacionais e administrativos, a fábrica era dividida em setores de componentes - de madeira, metálicos, fibra de vidro, espumas injetadas, espumas manufaturadas - e montagem, seguidos dos setores de pintura, acabamento e tapeçaria.

Já a parte administrativa era dividida em departamentos de vendas, marketing e protótipos (espaço de experimentações do designer e que funcionava como ponto de partida para a atuação dos setores periféricos). O protótipo era realizado manualmente, de forma artesanal. A partir dele, o produto era decomposto para a produção seriada, e suas partes eram dirigidas aos diversos setores. Percival manteve, com frequência, profissionais prototipistas ao seu lado. Um deles foi Antonio de Mitry, designer que viveu os anos de expansão da fábrica a colaborou na organização da cadeia produtiva. Mitry foi responsável pelo departamento de desenvolvimento de produtos juntamente com Percival. Muitas das expansões e oportunidades de terceirização, e consequentemente

Vista do setor de estoque de estofados e elementos em espuma injetável e fibra de vidro.

Fonte: arquivo do designer
17 Para não depender de fornecedores onerosos, nos anos 1980 e 1990, a Lafer fabricava os móveis utilizando a própria madeira. Em meados da década 90, concluindo um longo processo de reengenharia, que atingiu diversas empresas brasileiras, a Lafer adotou uma política mais enxuta, encerrando suas vendas no atacado, e mantendo a produção apenas para o abastecimento das lojas próprias e para a exportação. $\mathrm{O}$ terreno das instalações industriais de São Bernardo do Campo foi vendido para o Extra Hipermercado e a fábrica se transferiu para a Vila Prudente, em São Paulo capital, onde permanece até hoje. De acordo com Percival, "a venda da nossa área industrial foi no final de 1995. A transferência da produção para o lugar onde estamos hoje aconteceu em meados de 1996." 
crescimento dos setores e investimento tecnológico, são devidas à atuação de Antonio de Mitry. Prova disso, foi o desenvolvimento do setor automobilístico da Lafer, chefiado por ele. ${ }^{18}$

Com exceção de alguns colaboradores como de Mitry, a mão de obra contratada nunca era qualificada. Ao contrário, os operários eram treinados e especializados a desempenhar as tarefas dentro de uma cadeia produtiva. A clássica estratégia da redução da amplitude do trabalho operário foi usada para aumentar a produção. Tudo era produzido nos galpões da empresa. Poucos eram os serviços terceirizados. Durante a década de 80 , a MP Lafer chegou a utilizar a madeira que cultivava (Pinus Elliotti de reflorestamento) em uma fazenda localizada em Itapeva, no interior de São Paulo.

Muitos fatores contribuíram para a consolidação da marca e o crescimento industrial da MP Lafer. Como percebemos, a interação do designer com a fábrica era grande, e seu pensamento perpassava todos os processos - do projeto à venda. No entanto, é possível identificar dois marcos impulsionadores do crescimento estrondoso da empresa: a exportação e a terceirização de fabrico de produtos para o poder estatal e privado, em grande porte.

Em 1964, a convite do governo, produtores de diversos setores se reuniram na Federação das Indústrias do Estado de São Paulo (FIESP), com o intuito de lançar um plano de auxilio à exportação de bens de consumo industrializados. O primeiro passo foi a representação do Brasil na Feira Global de Negócios de Gotemburgo, na Suécia. Percival aderiu ao programa juntamente com outros empresários que receberam incentivo do estado.

Percival preparou um stand simples para apresentar seus produtos - do MP1 ao MP9 - no exterior. A exposição obtida em Gotemburgo, em 1965, multiplicou as possibilidades. Os produtos foram bem recebidos, encomendas foram feitas, a produção foi incrementada, e, a partir de então, a empresa passou a participar anualmente em feiras internacionais, com destaque para as de Colônia, na Alemanha, Milão, na Itália, e High Point, nos EUA. No Brasil, a Lafer mantinha participação constante nas feiras de utilidades domésticas, como a UD, Fenavem e Anhembi.

18 Para um aprofundamento da história do designer Antonio A. De Mitry, ver CURCIO, Gustavo; e MUYLAERT, Marília. Antpnio A. De Mitry - na prática, a teoria é outra. São Paulo: Senai-SP Editora, 2014. 
Foto aérea do parque industrial da Lafer Fonte: arquivo do designer

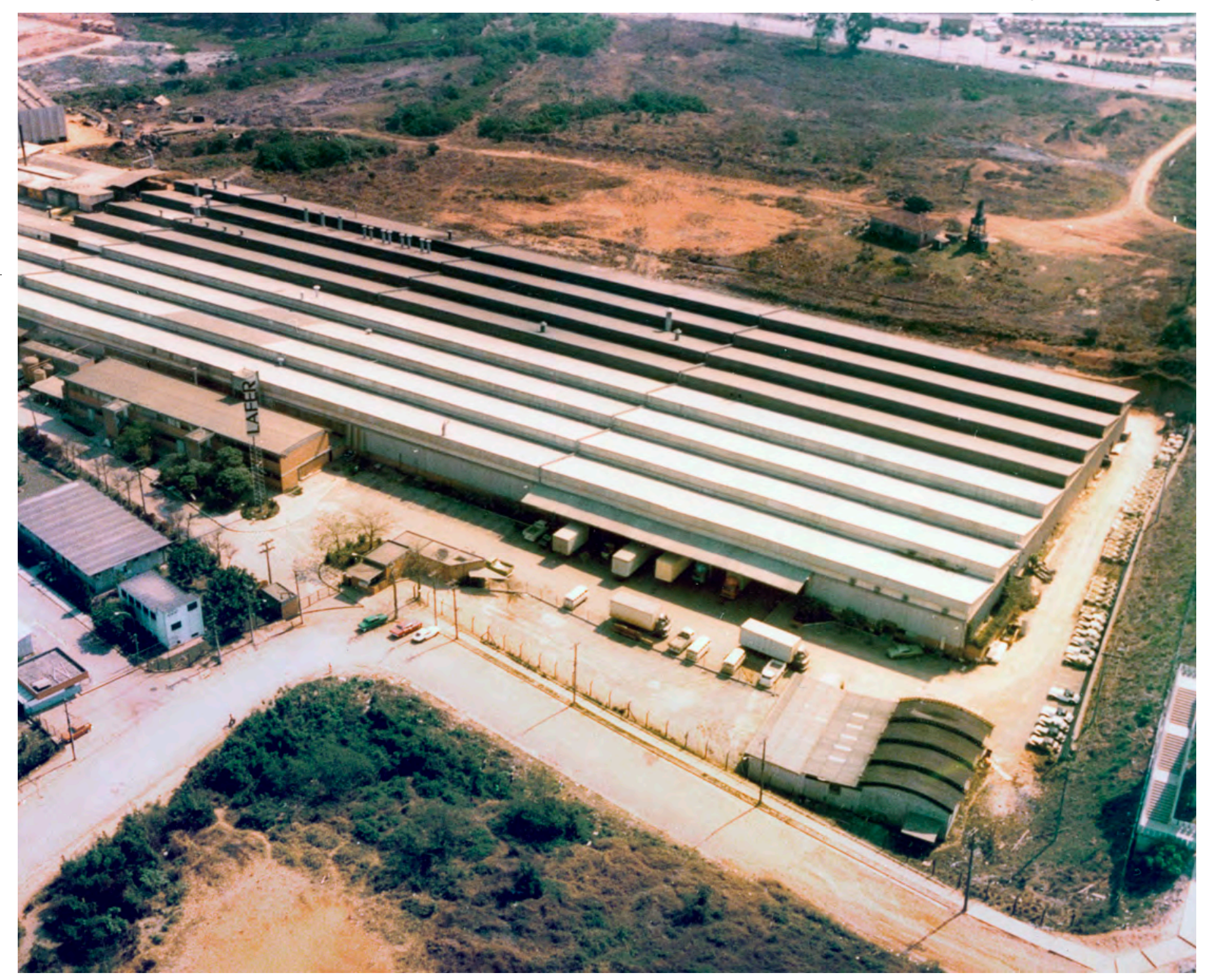


Embora entre os anos 1961 e 1965 o foco fosse o mercado nacional, muitos produtos foram pensados para o mercado externo, seguindo a imagem estrangeira e vendida do Brasil exótico. Sérgio Rodrigues havia aberto as portas da recepção ao novo luxo brasileiro com sua poltrona Mole, premiada poucos anos antes no Concorso Internazionale del Mobile, em Cantu, na Italia. ${ }^{19}$

A MP Lafer ofereceu ao mercado internacional exatamente o que esperavam, mas com preços mais acessíveis, já que dispunha de uma produção completamente otimizada e em grande escala. Os móveis eram totalmente desmontáveis e adaptados as barreiras de exportação. Além da diminuição com os gastos de taxas e impostos, tal aspecto facilitava a fabricação e a logística de distribuição da produção. Sofás inteiros chegaram a ser exportados em caixas de $20 \mathrm{~cm}$ de altura.
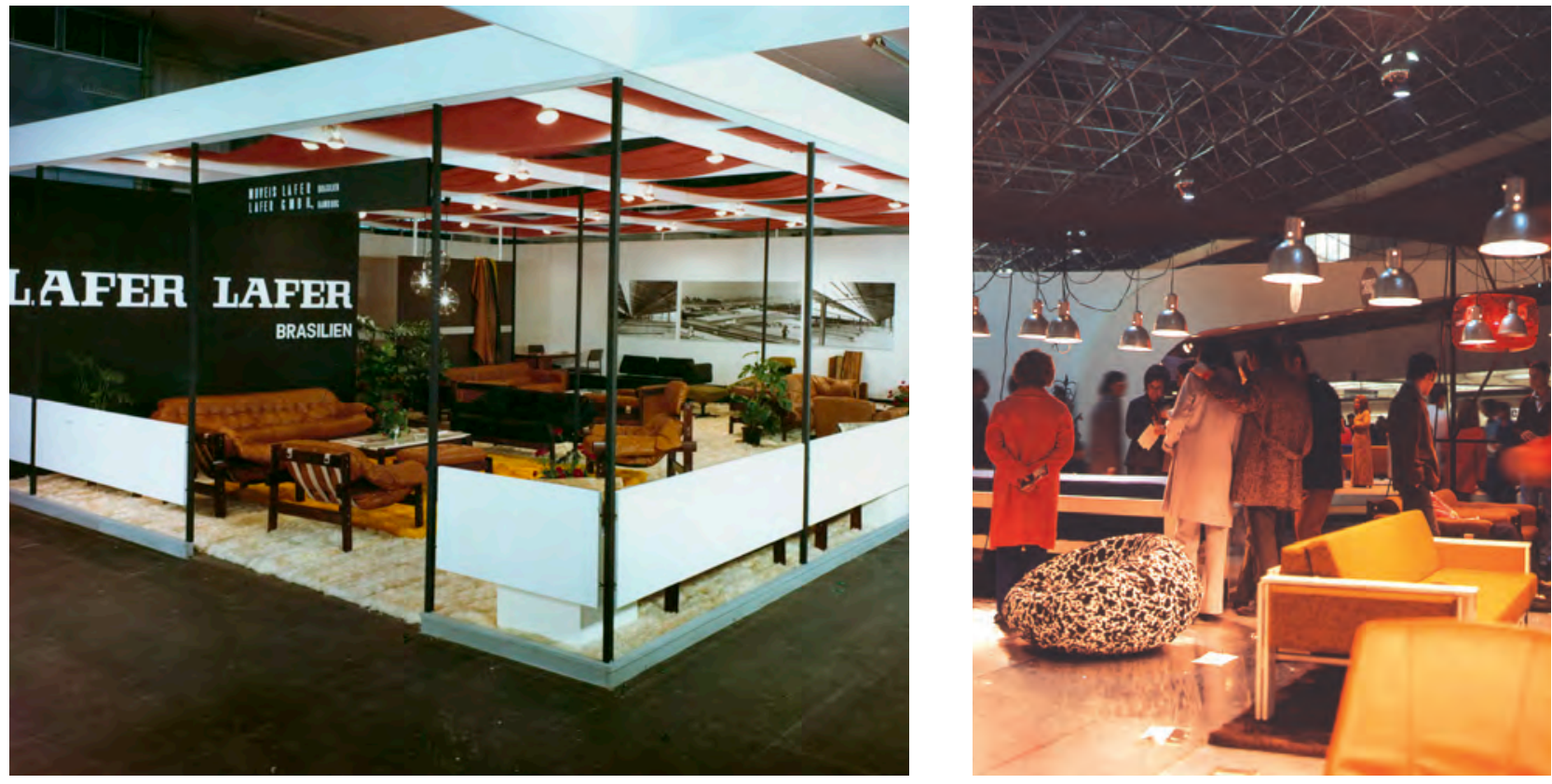

Vistas dos estandes montados em 1970 na feira de design da cidade de Colônia, na Alemanha, e na feira da UD em 1973, em São Paulo.

Fonte: arquivo do designer 


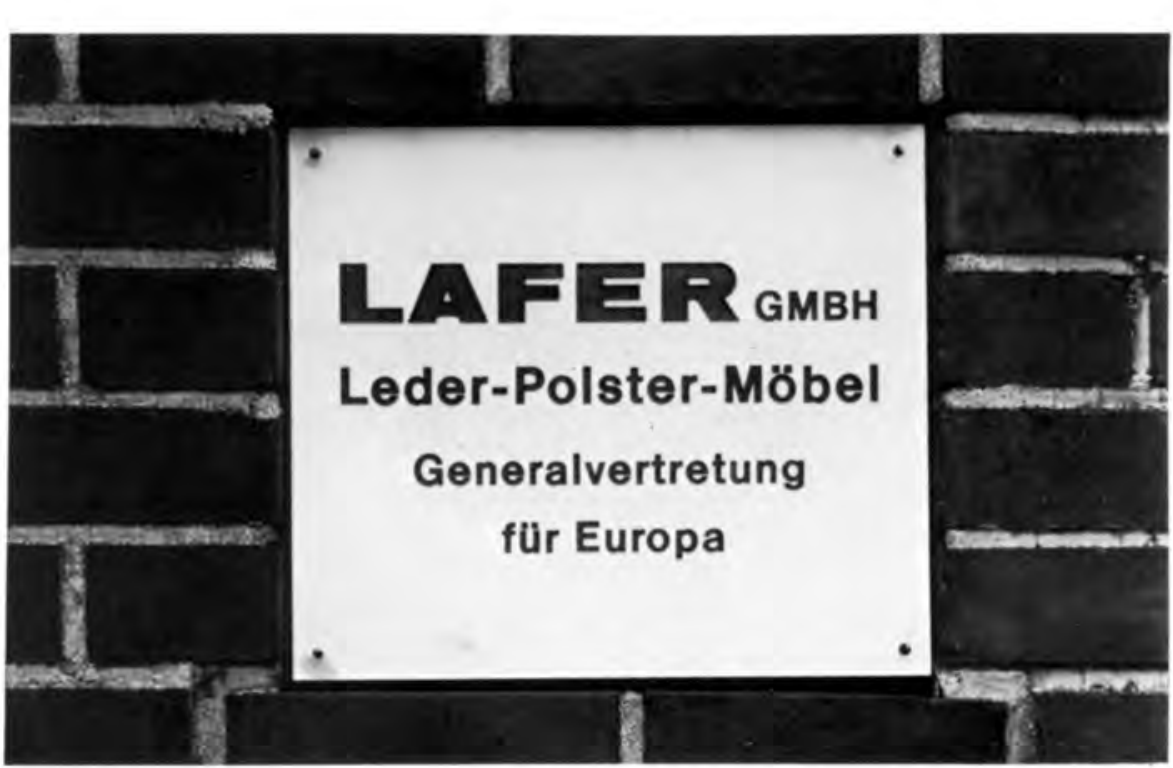

Anúncio

combativo da Lafer sobre a exportação de seus produtos para a Alemanha e outros paises da Europa.

Fonte: arquivo do designer

Todo mundo diz que exporta móveis para a Alemanha. Nós achamos que dizer é muito fácil e acreditar, muito difícil. Porisso, fotografamos a placa da nossa loja na Alemanha. Mostramos aqui também a embalagem dos nossos móveis exportados e o anúncio dos nossos móveis na revista alemã.

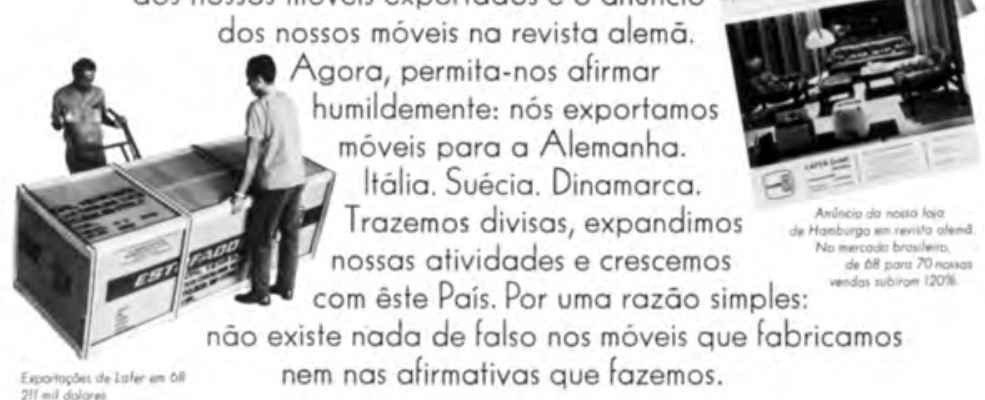
nem nas afirmativas que fazemos.

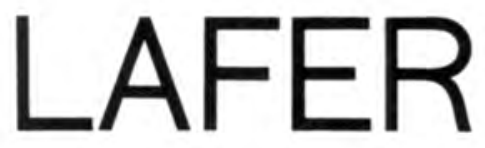

Os grandes entrepostos da marca foram a Alemanha e os E.U.A. No final da década de 1970, foi criada uma filial comercial em Hamburgo, na Alemanha. A loja montada com uma equipe de vendas. A dinâmica era a mesma adotada na comercialização no Brasil: representantes visitavam os comércios alemães oferecendo os produtos da MP Lafer. Já nos E.U.A, a empresa 'Brazil Contempo', marca de um amigo brasileiro, que vendia móveis e produtos brasileiros no exterior, representou a marca Lafer durante anos. Lafer chegou a desenhar peças exclusivas para a 'Contempo', especialmente poltronas em couro e madeira. A filial alemã, aberta em 1968, fechou em 1980, enquanto a parceria com a 'Contempo' durou até meados de 1985.

O período áureo das exportações foi de 1965 a 1985. Com o fim do "milagre brasileiro" e os planos econômicos catastróficos da era 


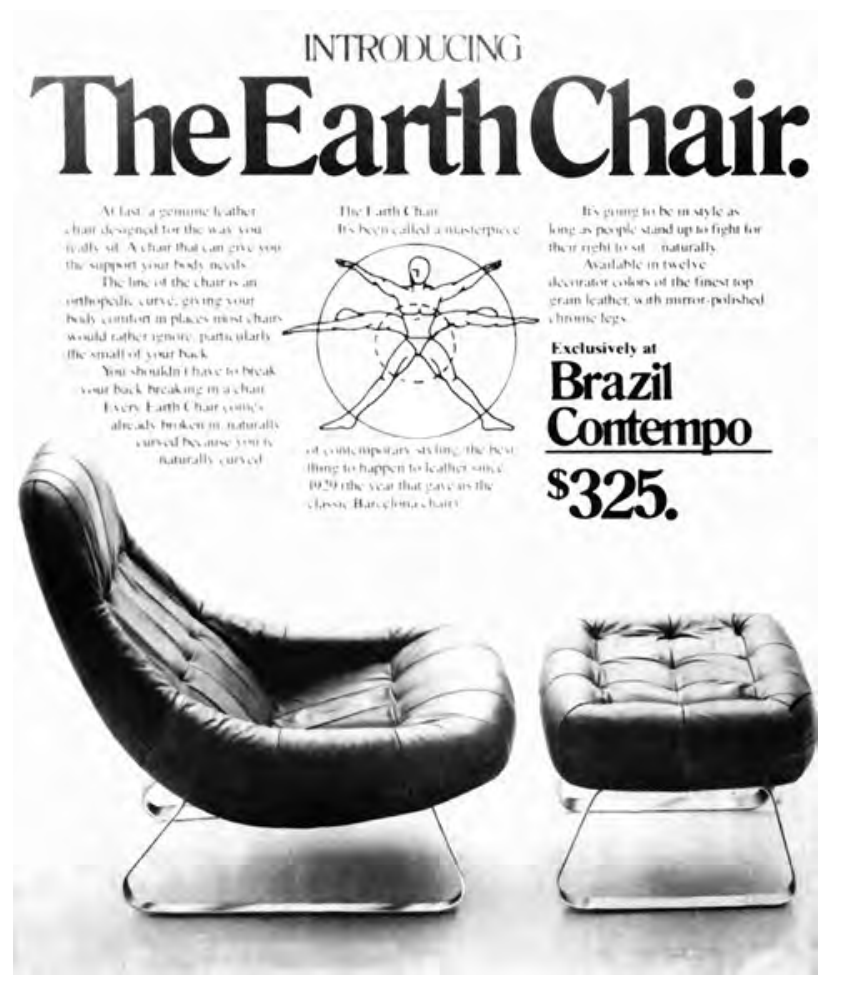

Anúncio de venda da poltrona Earth Chair, vendida nos estados unidos pela loja Contempo.

Fonte: arquivo do designer

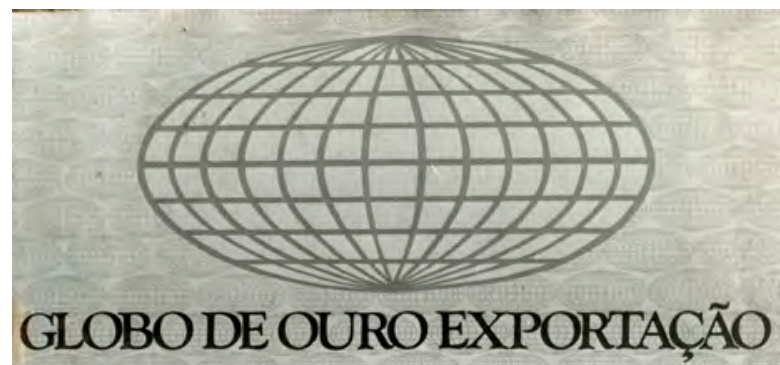

Destaque em Móveis em 1981 LAFER S.A. - INDÚSTRIA E COMÉRCIO

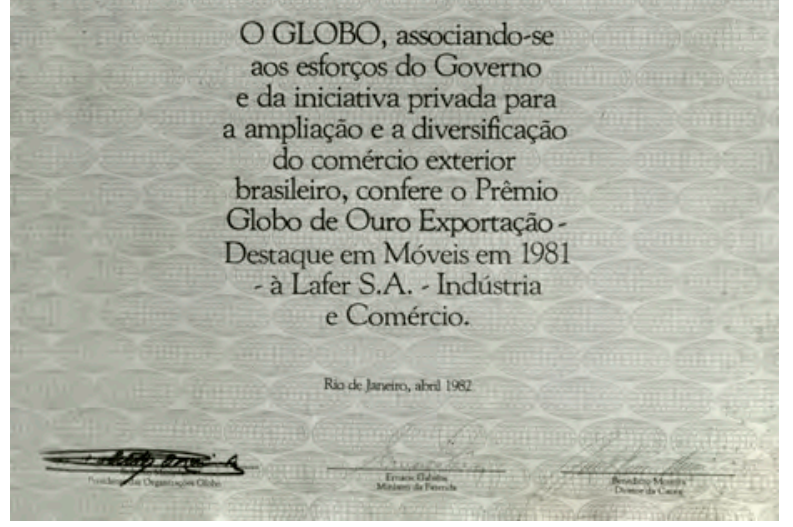

Prêmio Globo de Ouro da Exportação, concedido pelo Governo à Lafer.

Fonte: arquivo do designer

Sarney e Collor, houve uma mudança de cenário. A exportação foi reduzida, e apenas produtos que tivessem universalização de desenho, ou seja, o mesmo produto deveria ser vendido no Brasil e fora dele, foram comercializados no exterior. É o caso das poltronas reclináveis -produzidas e exportadas até hoje. A produção de alguns modelos da MP Lafer foram quase integralmente exportados. Na época, exportavamse produtos de madeira do sul do Brasil, produzidos com especificações estabelecidas pelos importadores. A produção obedecia o desenho vindo de fora, dentro de uma lógica de mercado onde a matéria prima e mão de obra eram mais baratas. Percival além de oferecer produtos de bom custo benefício, oferecia desenho. Esses fatores garantem, hoje, o alto valor desses móveis no mercado de antiquários na Europa e EUA.

Asegundagrande frente responsável pelo crescimento e sustentação da Lafer, inclusive em relação ao investimento e avanço tecnológico, foram os produtos de terceiros, desenvolvidos e fabricados pela empresa.

Frente e verso do anúncio de venda do quiosque MiniMulti. O conjutno era inteiramente fabricado em fibra de vidro.

Fonte: arquivo do designer 
Naquele momento, o uso da fibra de vidro era inovador e estava restrito ao de formas para o trabalho, com espuma injetada. Poucos campos industriais dominavam a técnica e possuíam maquinário e tecnologia de produção da matéria em questão. Assim, Lafer foi procurado por outras empresas para a terceirização de fabrico. As encomendas datam de 1970. Com a fibra de vidro, conseguiu-se uma diversificação de mercado. Para além da fabricação dos próprios móveis, a empresa aproveitou para produzir componentes para diversos setores da indústria.

O primeiro projeto foi uma encomenda de Caio de Alcântara Machado, para a produção dos módulos de lanchonete, bilheterias e outros equipamentos para mobiliar seu projeto do complexo Anhembi Parque, aberto em 1970, em São Paulo.

Lafer continuou suas pesquisas e desenvolveu quiosques reversíveis. O projetwo, batizado de MiniMulti, foi premiado em 1974, pelo Instituto de Arquitetos do Brasil (IAB), na categoria Desenho Industrial. Villanova Artigas fazia parte do júri. O módulo era um dispositivo para múltiplas funções, podendo ser usado temporariamente e deslocado no espaço. O projeto, muito engenhoso, possuía uma tampa/ cobertura que
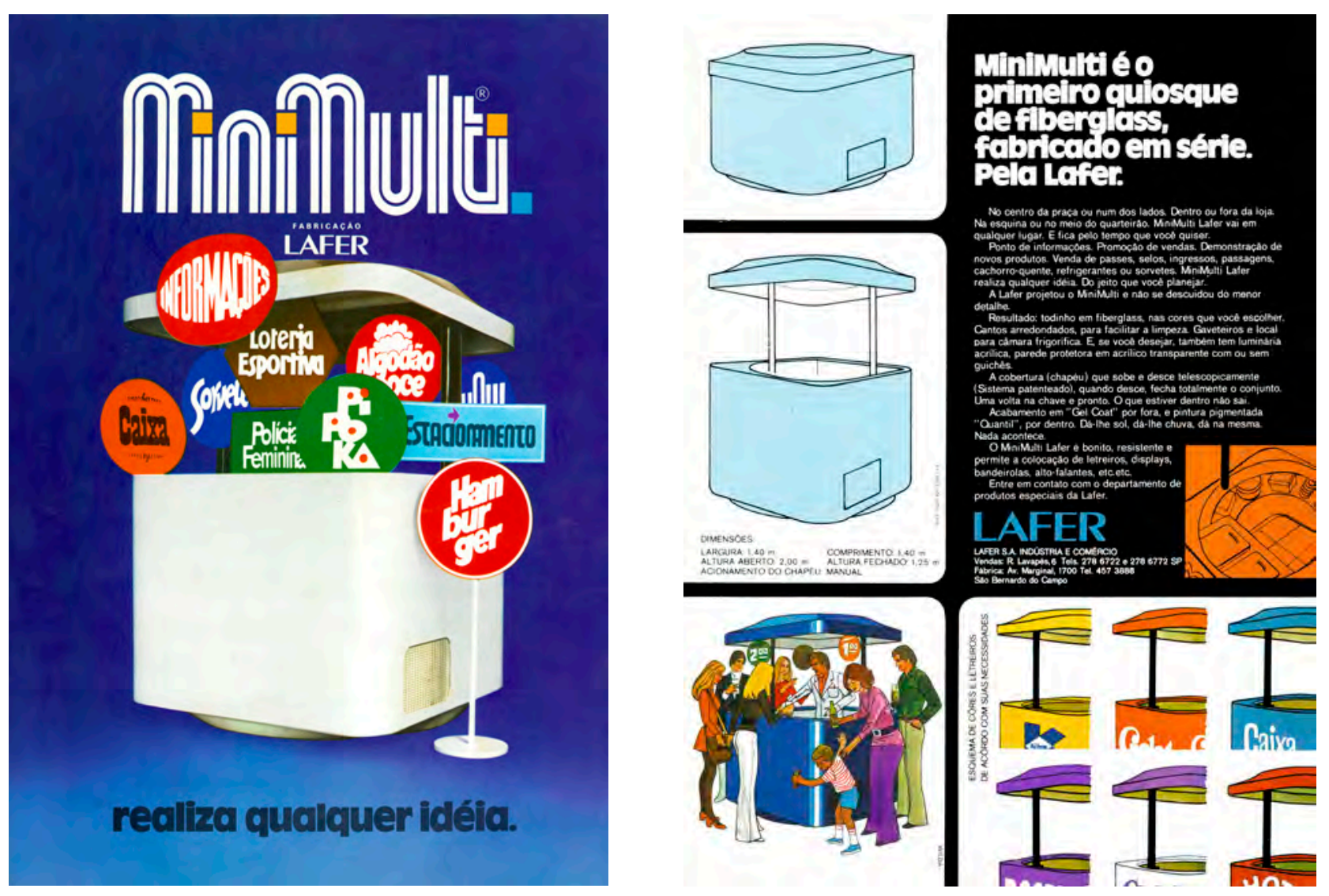
resolvia a questão do fechamento e proteção contra intempéries. A publicidade deixa claro as possibilidades de uso do conjunto.

É importante ressaltar que Percival possuía o controle total sobre a criação, produção, difusão e venda, ocupando-se das tarefas criativas envolvidas em cada um desses campos. Os stands, publicidades, ambientes decorados, as próprias lojas eram desenhados e pensadas por Percival. Dessa forma, a imagem da MP Lafer se apresentou muito coesa, o que ajudou na ampliação das vendas.

No que tange à terceirização de serviços, outros grandes projetos foram absorvidos pela MP Lafer, sendo o de maior amplitude, a produção das icônicas cabines telefônicas da Companhia Telefônica Brasileira (CTB), o famoso orelhão.

Em 1972, por indicação de Joaquim Teixeira Marinho, exfuncionário da Teperman, Percival Lafer e seu colaborador Antonio de Mitry aceitaram a encomenda de desenvolvimento projetual e

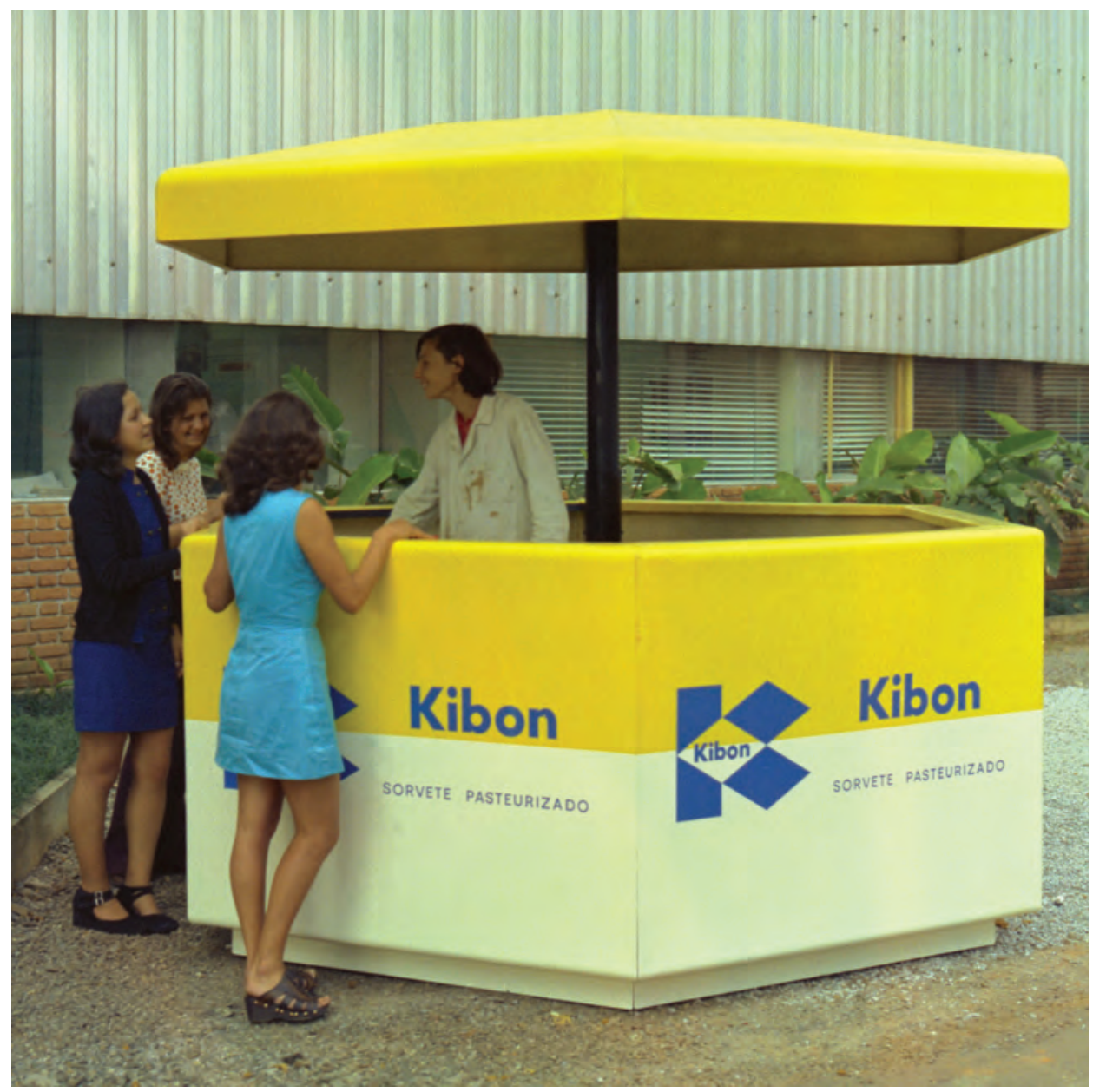

Um dos protótipos realizados para o desenvolvimento do produto MiniMulti sendo testado.

Fonte: arquivo do designer 
fabricação dos novos pontos públicos de telefonia. A ideia e anteprojeto foram idealizados pela arquiteta Chu Ming Silveira que, após anos de pesquisa, chegou a forma oval tão conhecida. Lafer e Mitry desenvolveram o protótipo, rapidamente aprovado pela comissão.

O primeiro produto produzido foi o "orelhinha", em acrílico de 6 e $10 \mathrm{~mm}$, colorido. Para instalação em ambientes internos, funcionou como um teste para a sequência dos projetos desenvolvidos. Em seu memorial descritivo, a arquiteta escreve sobre as soluções e dificuldades encontradas para desenvolver o orelhão como o conhecemos:

"Orelhão - O caso do orelhão é o mais delicado, pois deve atender as condições mais desfavoráveis: aplicação externa, a todo tipo de público. Alto nível de ruído nas vias públicas e atendimento a concentração diferentes, para o que foi criado um modelo modular a três níveis, que pode ser facilmente desenvolvido para um número $n$ de orelhões, bastando usar um adaptador adequado.

A sua forma foi desenvolvida com base no orelhinha, adequando-o à nova problemática e procurando atender a todos os itens da lista de registros propostos. Para o orelhão foi dispensada a transparência, necessária em ambientes fechados e semi-abertos, o que possibilitou a alternativa de fiberglass, que aumentou ainda mais as condições de privacidade do usuário. Seu funcionamento é análogo aos anteriores, sendo que atende bem à faixa de 40 à 90 decibéis, acima do que uma cabine totalmente fechada será o ideal." ${ }^{20}$

Com a coordenação de Antonio de Mitry, a MP Lafer desenvolveu o projeto, ampliando a importância do setor de fibra de vidro. A empresa forneceu os componentes do orelhão por mais de dez anos. Isso só foi possível pelo investimento em tecnologia e ampliação do setor de fibra de vidro que passou a ser um dos maiores do parque industrial.

A partir dessa primeira grande encomenda, Percival foi convocado para desenvolver outros tipos de cabines telefônicas, agora com desenho

20 SILVEIRA, Chu Ming. Memorial Descritivo. São Paulo, 1972. Disponível em $<$ http://www.orelhao.arq.br>. Acesso em: 08 de novembro de 2017. Para consultar o Memorial descritivo completo, ver Apêndice p.200. 


\section{Protetores Telefônicos Lafer de fiberglass e de acrílico.}

Ao planejar a distribuição de aparelhos telefônicos, você vai enfrentar solicitações novas: aparelhos bem mais protegidos; fáceis de identificar; agradáveis aos olhos.

\section{E dotados de}

recursos acústicos que eliminem as interferências sonoras externas. (Orelhão)é a solução.
Protetor Telefônico Lafer
O brasileiro já aprendeu a não deixa por menos. Exige.

O protetor Telefônico Lafer é fabricado em dois módelos (fiberglass e acrílico), e acomoda qualquer tipo de telefone.

O desenho é da TELESP. A fabricação é exclusividade Lafer.

Esta é a garantia maior para o melhor som.

$\mathrm{E}$ a mais atual imagem.

Tanto da cidade como de quem os instala. gostar deles e

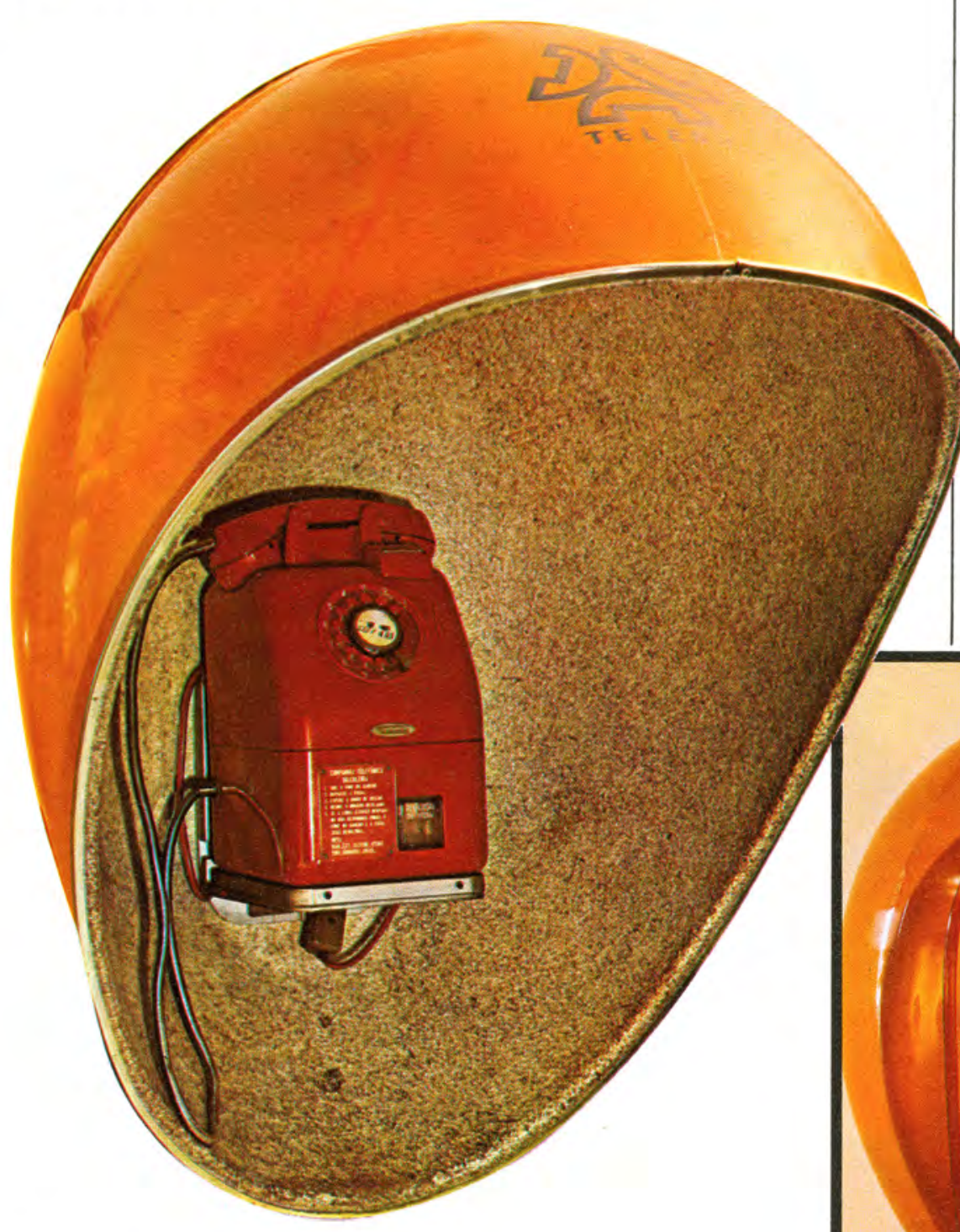

Protetor Telefônico Lafer de fiberglass

Fornecido em diversas cores. Ideal para exteriores, por sua grande resistência às variaçốes de temperatura, ao sol e à chuva, e pela facilidade de manutenção e limpeza.

Altura máx. $1.03 \mathrm{~m}$ Largura máx. $0.70 \mathrm{~m}$ Profund, máx $0.88 \mathrm{~m}$

Acabamento das bordas: perfil de alumínio Acabamento externo: "Gel Coat"

Acabamento interno: Pintura Pigmentada

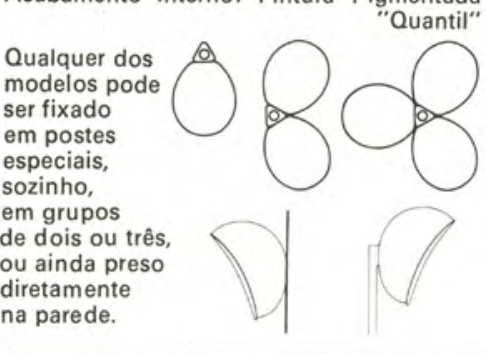

Protetor Telefônico Lafer de acrílico

Inteiramente transparente. Fornecido em diversas cores. Ideal para interiores, por reunir maior beleza

às suas qualidades funcionais. Altura máx. $0.83 \mathrm{~m}$ Largura máx. $0.62 \mathrm{~m}$ Profund. máx. $0.47 \mathrm{~m}$

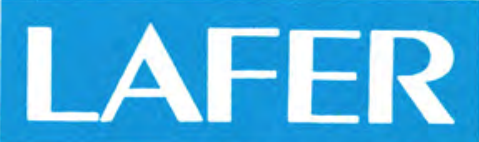

LAFER S.A. INDÚSTRIA e COMERCIO Vendas:

R. Lavapés, 6 Tels. 2786722 e 2786772 SP. Fábrica:

Av. Marginal, 1700 Tel. 4573888

Săo Bernardo do Campo

FIBERGLASS 
próprio, em pedido feito pela Embratel. Lafer desenvolveu um sistema modular de cabines, completamente produzidos em fibra de vidro. As cabines eram modulares e se adequavam facilmente às contingências da construção dos chamados postos telefônicos por todo o Brasil. Outros modelos de cabines foram desenhados e produzidos para empresas de telefonia durante anos.

Em uma das publicidades sobre a nova cabine, a MP Lafer dá um panorama rápido de seu crescimento e fala sobre a diversificação produtiva que ocupava "[...] a fábrica de 15 mil metros quadrados e [sem] um minuto de capacidade ociosa."

Diversos outros insumos também foram produzidos - portas de armário, para uma empresa francesa, e spoilers automotivos (pequenos dispositivos acoplados a carroceria para maior estabilidade do veículo). Nesse período já estava em pauta a ideia de criação e produção de um automóvel.

\section{Moveis Lafer pede licenca para falar o tempo maximo de 3 minutos sôbre estas cabinas}

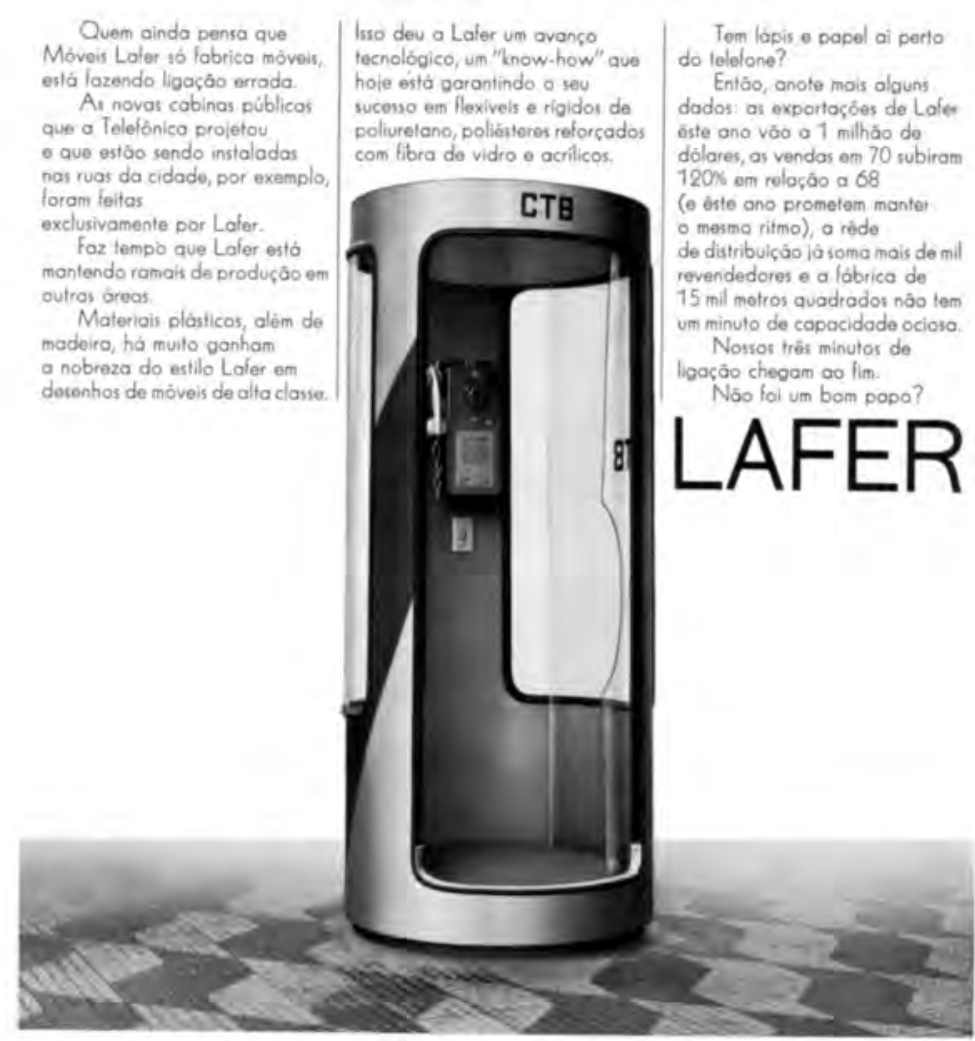

Anúncio da cabine de rua circular Lafer

Fonte: arquivo

do designer
Anúncios da

Cabina Modular,

desenhada e produzida por

Lafer para os postos telefônicos (pág. 65),

Fonte: arquivo do designer 


\section{CABINA MODULAR}

\section{Características Técnicas}

Esta é a Cabına Modular Lafer

Toda de fiberglass, a Cabina Modular Lafer é ideal para ınterıores.

Tem porta de vidro temperado que gira sobre pivotantes cromadose um prático puxador

Seu estétıco acabamento é em "Gel Coat"

Sua acústica è perfeita.

Apoio moldado na própria cabına para anotacões, ventılacão forcada através de cırculador de ar, lumınária em acrilico com lampada

fluorescente.

Tudo perfeito para o conforto interno

Com a Cabına Modular Lafer ficou muito mass fácıl projetar e padronizar os postos de servicos telefônicos Resolve também o problema em hotèis, hospitais, escritórios. industrias etc.

A Cabına Modular Lafer è fornecida na cor que você determınar

Pode ser instalada uma unidade.

Podem ser ınstaladas várıas unıdades acopladas. Sempre da mesma maneıra: embutıdas. Numa só parede ou formando cantos. Nestes casos são fornecıdos também paınés laterais de acabamento no mesmo materıal da cabına.

Cabına Modular Lafer è bonıta, silencıosa, resistente, confortável e. acıma de tudo, fácıl de ınstalar
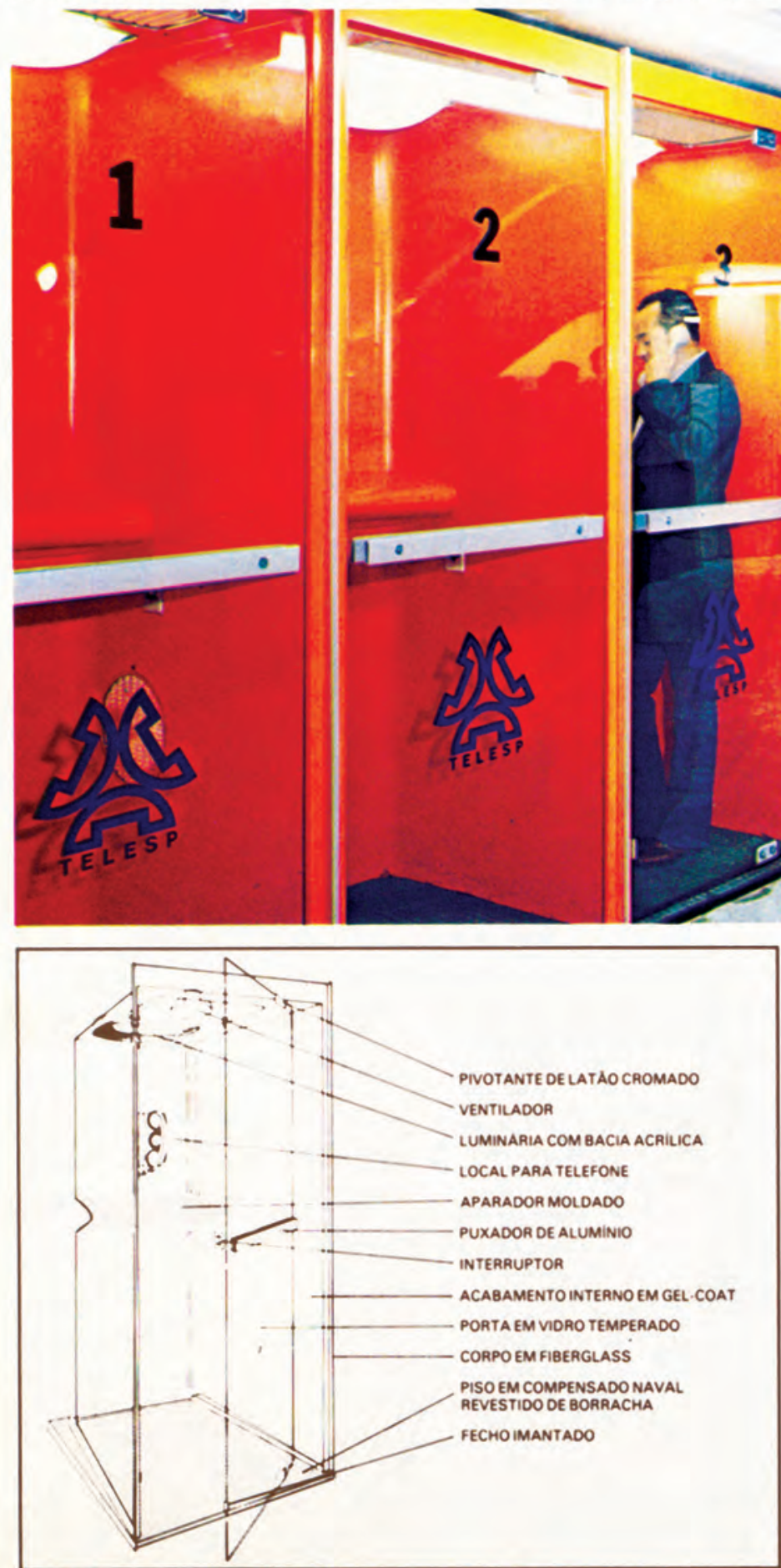

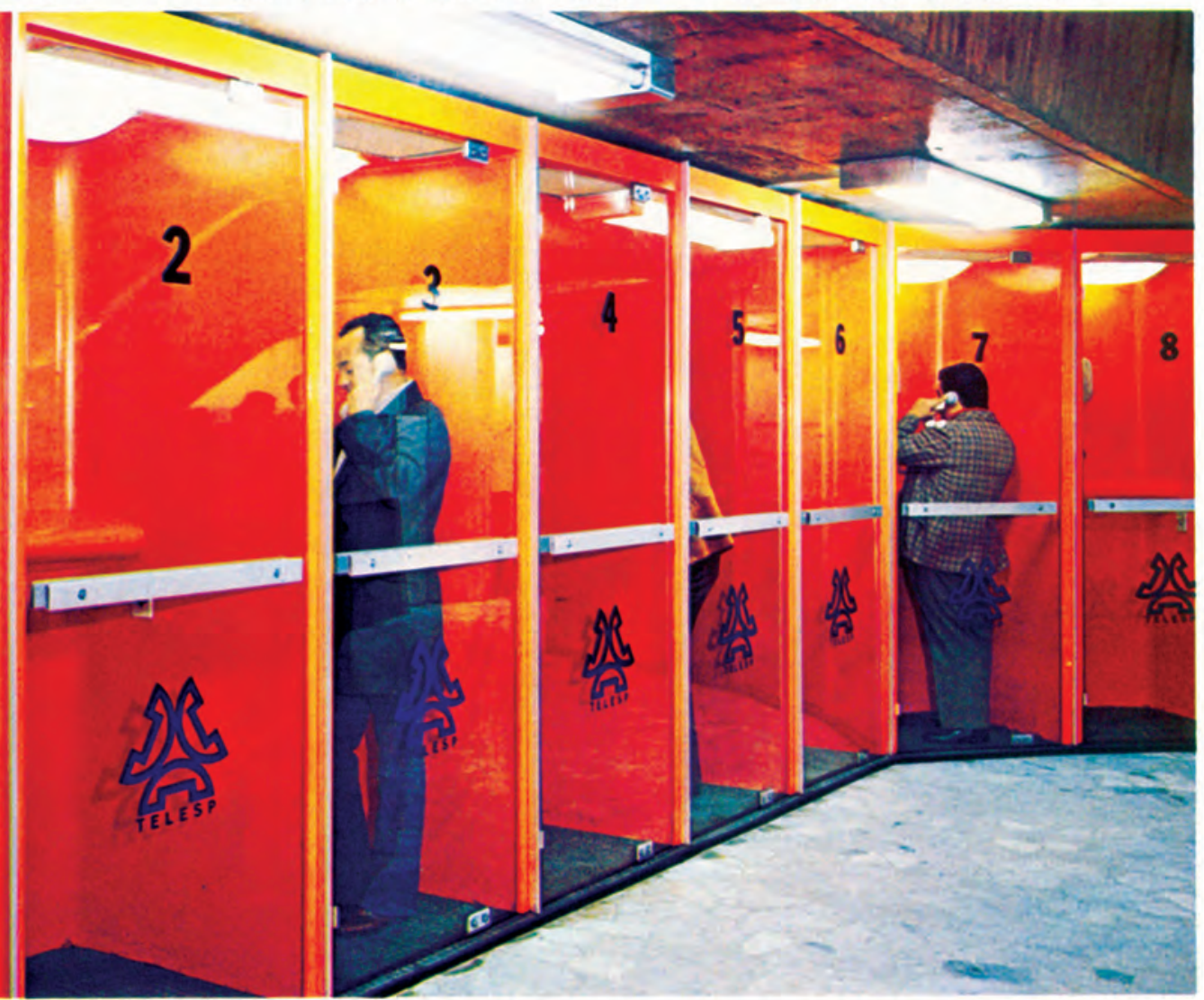

Conheca a Cabina Modular Lafer mais de perto

Entre em contato com a Divisão de Produtos Especiais da Lafer.

\section{Dimensões}

$\begin{array}{ll}\text { Altura } & 2.10 \mathrm{~m} \\ \text { Largura } & 0.85 \mathrm{~m} \\ \text { Profundıdade } & 0.85 \mathrm{~m}\end{array}$

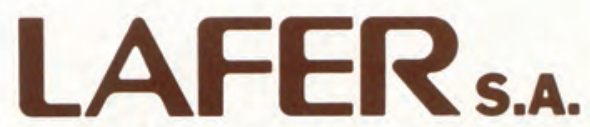

Divisão de Produtos Especiais

R. Garcia Lorca, 301

Tel. (011) 4570022

S. B. Campo - SP 

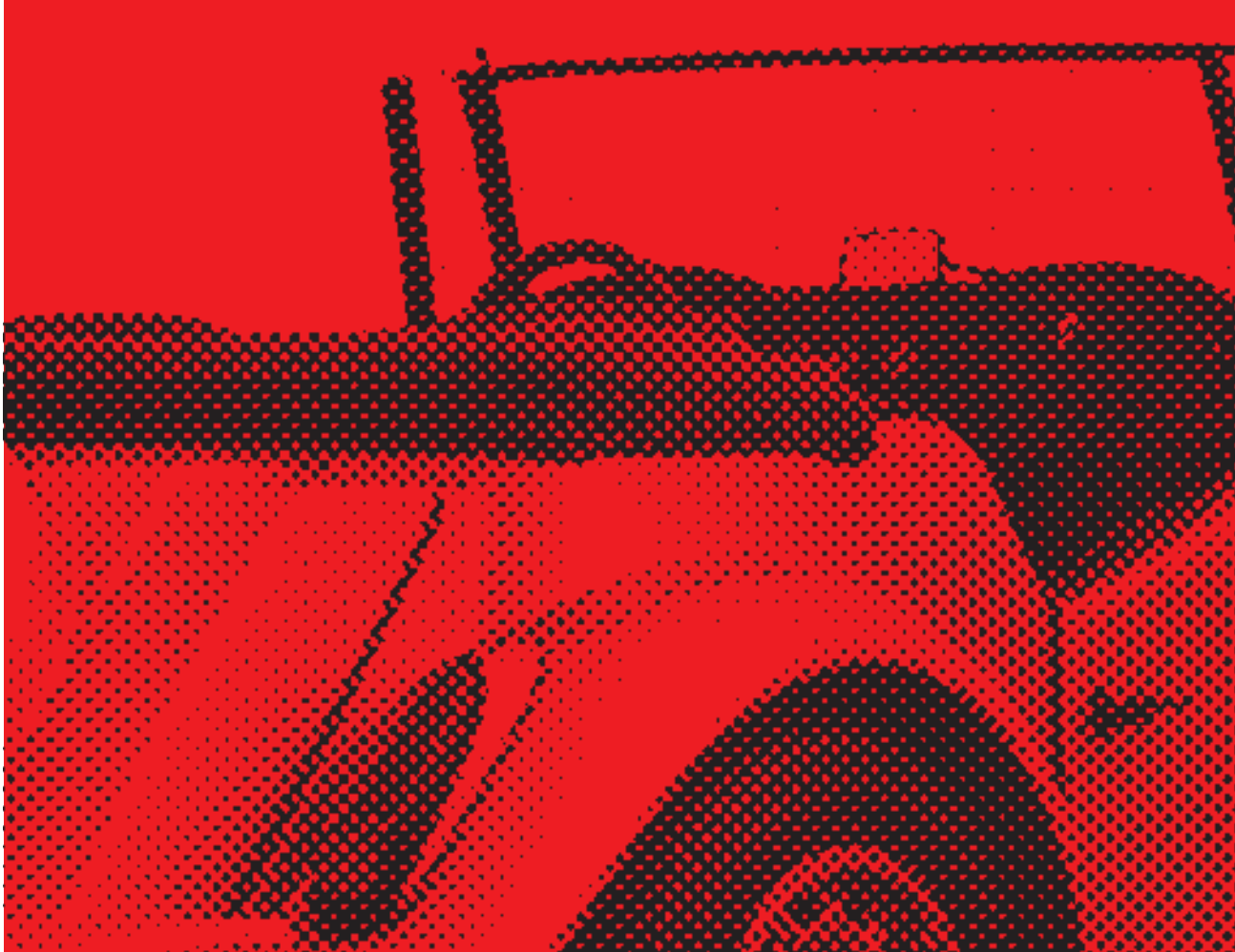

$\cos 6000$

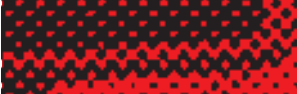

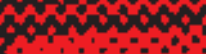

808000 00000 6
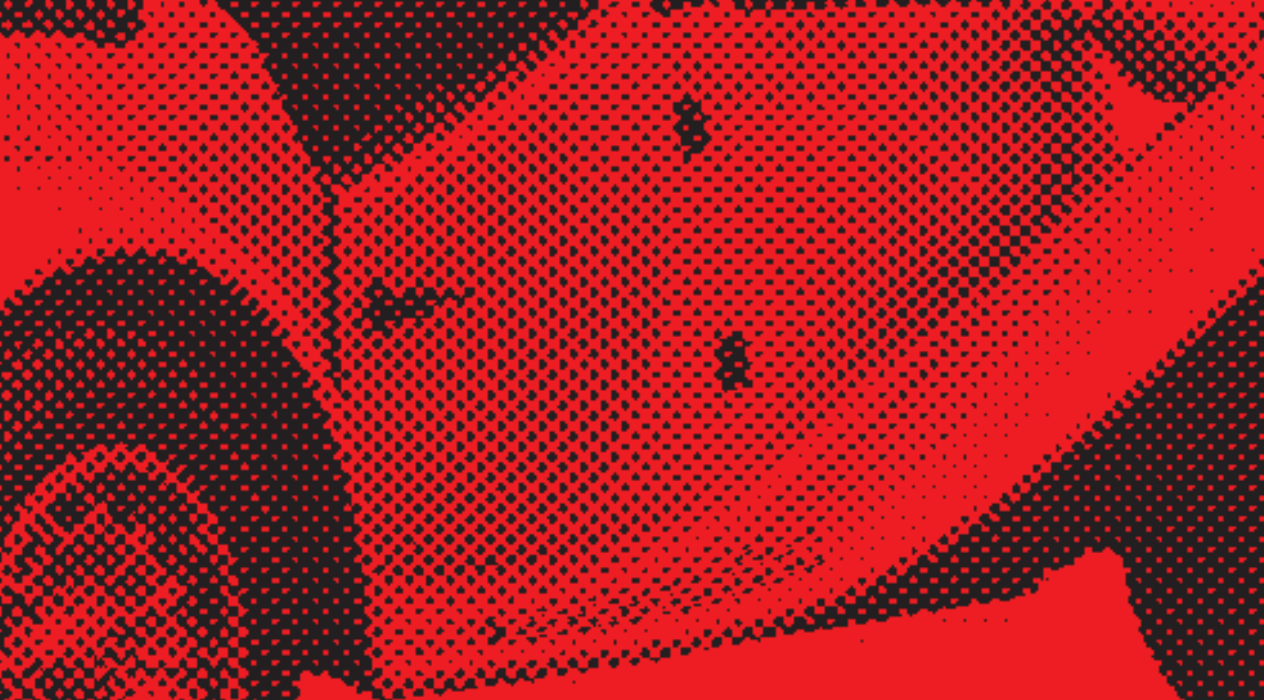


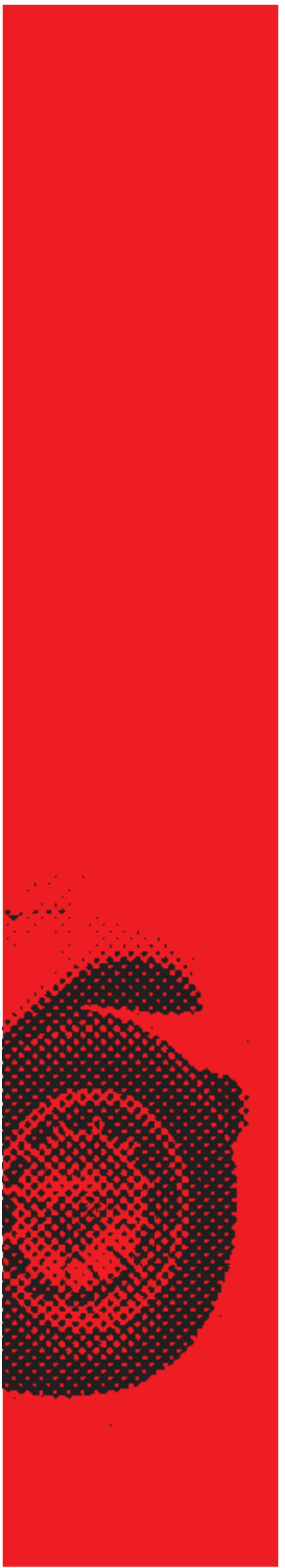

\section{LAFER E O AUTOMÓVEL - SOFÁ SOBRE RODAS}

A despeito da aparente fluência e unidade que a trajetória criativa de Percival Lafer possa ter, é necessário lembrar que ela também é composta de percalços e ocasos, e, nem sempre, seus resultados são fruto de um pleno controle. Seria ingênuo pensar que o construto seja apenas reflexo de um prodígio, bem como da casualidade. Fatores de várias ordens, endógenos e exógenos a experiência individual, tecem o curso das coisas. $O$ crescimento e solidificação da empresa MP Lafer, assim como qualquer outro exemplo, não foi uma exceção. Seja na criação dos móveis, seja no investimento em tecnologias precisas, o percurso traçado foi construído paulatinamente, com ajuda de colaboradores, aproveitando-se as oportunidades que foram aparecendo. No caso da Lafer, isso fica mais evidente quando analisamos sua intercorrência no campo de desenho e produção automobilísticos.

A primeira pergunta que se esboça é: porque um designer produtor de móveis modernos aventurou-se a produzir um calhambeque? A resposta a essa pergunta não é evidente, considerando que muitos fatores subjetivos fogem à pesquisa. No entanto, iremos ensaiar algumas considerações a cerca desse evento, que, em sua peculiaridade, se mostra revelador.

A partir de meados de 1950, por incentivo do governo de Juscelino Kubitschek, colocou-se em curso um movimento de nacionalização produtiva do automóvel. Até então, os automóveis eram, em sua totalidade, produtos importados. A criação do Grupo Executivo da Indústria Automobilística (GEIA) auxiliou a entrada de fábricas do setor no país. Industriais brasileiros começaram a fazer frente à produção das empresas estrangeiras, motivados pela representação publicitária que o automóvel conseguia por meio das corridas de esporte. ${ }^{1} \mathrm{O}$ hábito de customização dos automóveis era uma constante, o que criou o ambiente propício para que a produção dos carros ditos "fora-de-série" fosse iniciada.

Percival Lafer foi nesse ambiente por seu colaborador Antônio de Mitry21, designer e projetista de elementos automobilísticos, principalmente estofados. Os dois já se conheciam. Percival fora cliente da empresa de De Mitry, a 'Redecar,' que oferecia para concessionárias e público em geral, peças e elementos para a customização de automóveis. A partir de 1969, De Mitry passa a colaborar na fábrica de Percival como coordenador geral de produção e inovação. A parceria resultou numa 
melhoria dos processos de produção e seriação da indústria de Percival. Com a nova equipe montada por De Mitry ${ }^{22}$, houve um aprofundamento de conhecimento técnico, além de investimento tecnológico nos setores de fibra de vidro e injeção de espuma, o que proporcionou ampliação dos recursos produtivos, além de soluções criativas para diversas linhas de mobiliário, principalmente aos pertencentes à expressiva linha de final 1 , e do desenvolvimento de produtos especiais, como o "orelhão".

A partir de uma primeira ideia de Luis Ortega, proprietário da empresa de patentes que prestava serviços tanto para Percival como para De Mitry, ambos decidem participar do Salão do automóvel de 1972, com uma réplica nacionalizada do famoso calhambeque inglês MG-TD, que por trocadilho e recebeu o nome de MP-LAFER. De Mitry foi o maior entusiasta. $O$ primeiro protótipo foi construído em apenas 28 dias, ficando pronto no dia da inauguração do Salão do Automóvel.

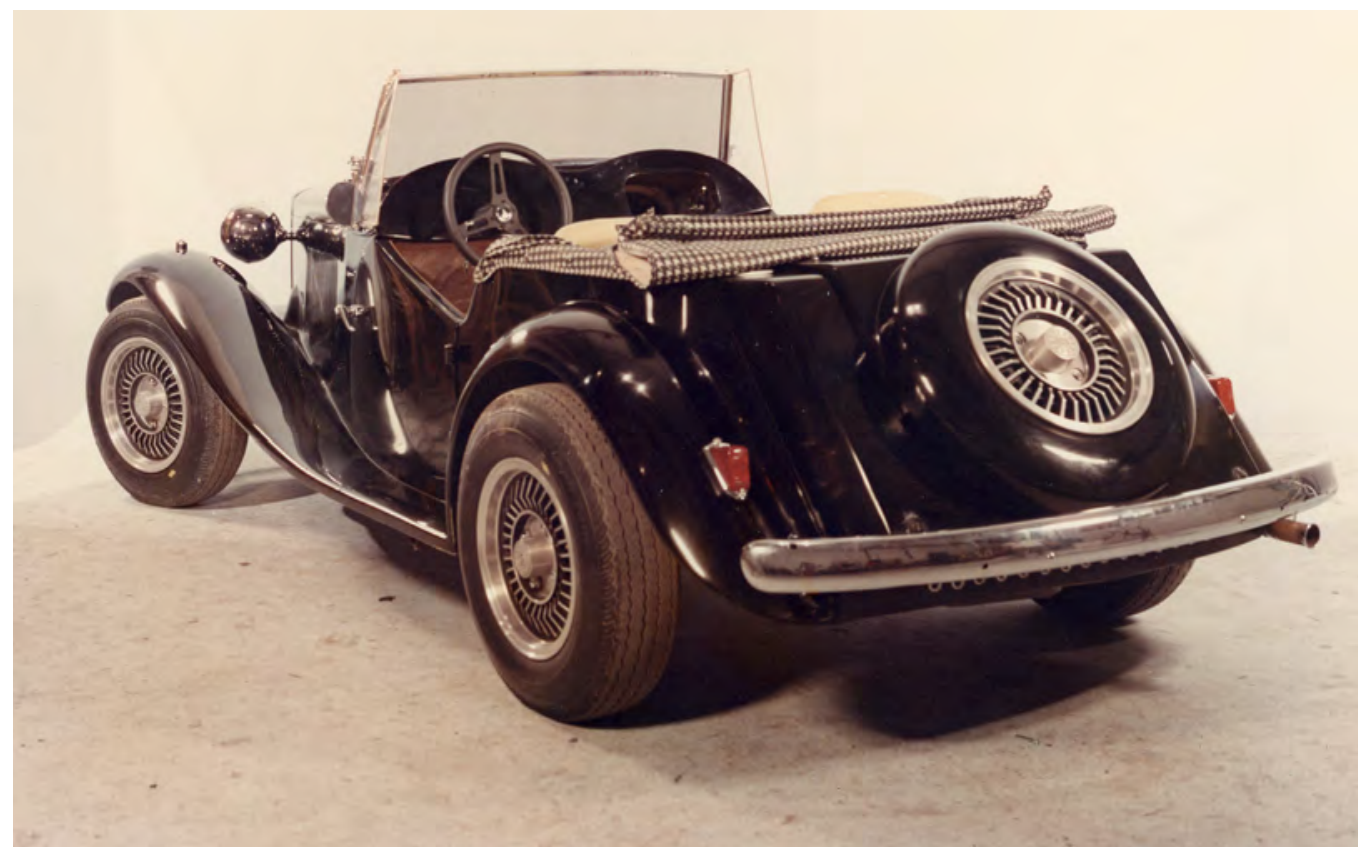

Pg. 66 - foto do automóvel

MP LAFER, produzido pela

Lafer entre os anos 1970 e 1980 .

Fonte: arquivo do designer
Primeiro MP produzido e apresentado no Salão do Automóvel de 1972.

Fonte: arquivo do designer
22 Em entrevista a Jean Tosetto, De Mitry conta: "Percival Lafer era arquiteto e nossos pontos de vista coincidiam. Introduzi uma série de perfomances e novidades na linha de produção. Iniciei executando espumas de poliuretano em blocos. Depois, em método inédito de injeção em espumas moldadas, montamos a divisão de fiberglass para atender os moldes dos injetados. Então, trouxe um amigo, Sebastian Garcia, para montar a seção de acrílico para objetos decorativos, lustres e abajures. [...] Montei um departamento técnico para desenvolver produtos, admitindo o senhor Arima - um marceneiro e modelista genial; um laminador de fiberglass chamado João Arnault; outro modelista vindo da FEI, de nome Osmar "Gaúcho"; um tapeceiro modelista de nome Dorival Lopes Cabrera Abarca [...] outro ajudante geral de nome Edson [...]. Essa era a equipe coordenada por mim e que Percival adorava, pois podia criar qualquer produto, que nós executávamos [...]. " TOSETTO, op. Cit. P. 46. 
Tecnicamente, o carro era composto de uma carcaça de fusca, cujas distâncias de eixo eram as mesmas do modelo MG-TD. O motor era do Volkswagen Brasília. A carroceria era completamente moldada em fibra de vidro, de forma inteiriça. Para os acabamentos foram usadas técnicas já conhecidas e operacionalizadas na fábrica para a confecção dos móveis. O motor foi invertido, migrando para a parte traseira do carro, num jogo de contrapeso. A parte dianteira era vazia, e a grelha de ventilação pura decoração ${ }^{23}$. Resumidamente, o MP-LAFER era o contrassenso "publicitário" da transformação estética de um carro em um outro.

O automóvel ganhou o mercado em 1974, com uma produção inicial de um veículo por dia, dobrando posteriormente. O preço não era acessível, ainda mais se comparado a outros carros de linha que possuíam mais vantagens de custo benefício. O MP-LAFER foi concebido enquanto "carro fetiche", e foi nessa chave de venda que ganhou o mercado. A imagem remetia diretamente a valores pseudo-aristocráticos de elegância e riqueza, exatamente o que as classes médias e altas buscavam como forma de ostentar status. Para as classes mais baixas, a coisa ficava no campo do desejo reprimido, e para os pobres a possibilidade não existia.

A opção pela forma do calhambeque seguia a ideia americana esdrúxula de reproduzir carros de época, tão difundida pelo cinema americano, fruto do "empurre-goela-abaixo" da indústria cultural. Carmem Miranda, em uma cena de "Uma Noite no Rio", hollywoodiano de 1941, recebe o gringo "diplomata" montado num calhambeque muito parecido com o MG-TD, MP-LAFER. Três décadas antes já se reproduziam carros com desenho anacrônico do começo

23 Sobre os processos de construção do carro, Pimenta, um dos funcionários de Lafer, narra na voz de Tosetto: "Quando o conjunto mecânico da VW chegava ao galpão da Lafer, era logo equipado provisoriamente com rodas velhas de Fusca ou Brasília, além de pneus carecas. Procedia-se então com o recuo das pedaleiras e da alavanca de câmbio. O freio de estacionamento era verticalizado, com o auxílio de uma chapa triangular, para ficar semelhante ao da Kombi. A coluna da direção era substituída, assim como o tanque de gasolina. Os cabos do acelerador e da embreagem eram redimensionados - o mesmo ocorrendo com os leitores do velocímetro e do conta-giros. [...] Enquanto isso, a carroceria secava no sol e na chuva durante 25 a 30 dias. [...] Depois da secagem total, as carrocerias eram lixadas antes de serem instaladas nos chassis, com os quais formavam uma estrutura rígida. [...] O conjunto era completado pelas portas dos passageiros e tampas do bagageiro e motor [...] ajustadas individualmente em cada exemplar. [...] Antes da montagem final [...] passavam para a seção de pintura, onde eram necessárias 16 camadas de tinta e três de verniz, para dar o brilho desejado. Só a partir de então eram feitas a tapeçaria, a instalação dos bancos estofados e do painel de madeira, a montagem da capota, do parabrisa, da forração das portas, dos instrumentos de leitura e demais componentes elétricos e mecânicos." Tosetto, op. Cit., p. 66. 


\section{THE MAFER, POINT BY POINT}

Folheto técnico

e publicitário do MPLafer.

Fonte: arquivo do designer
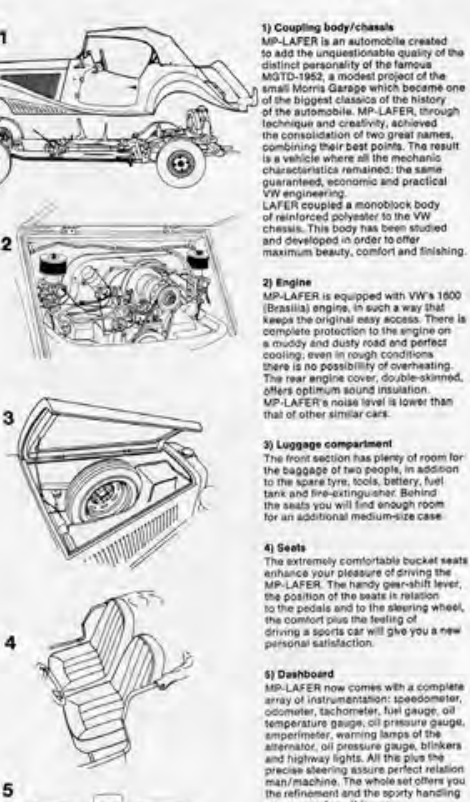

5

(ब) 90.7

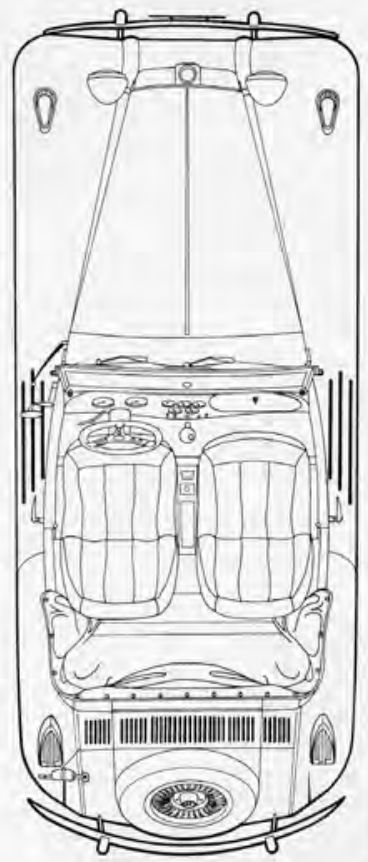

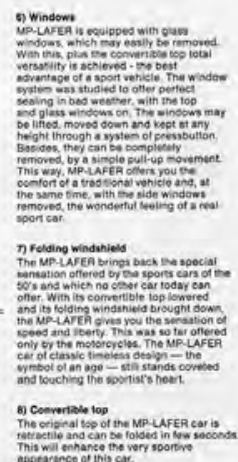
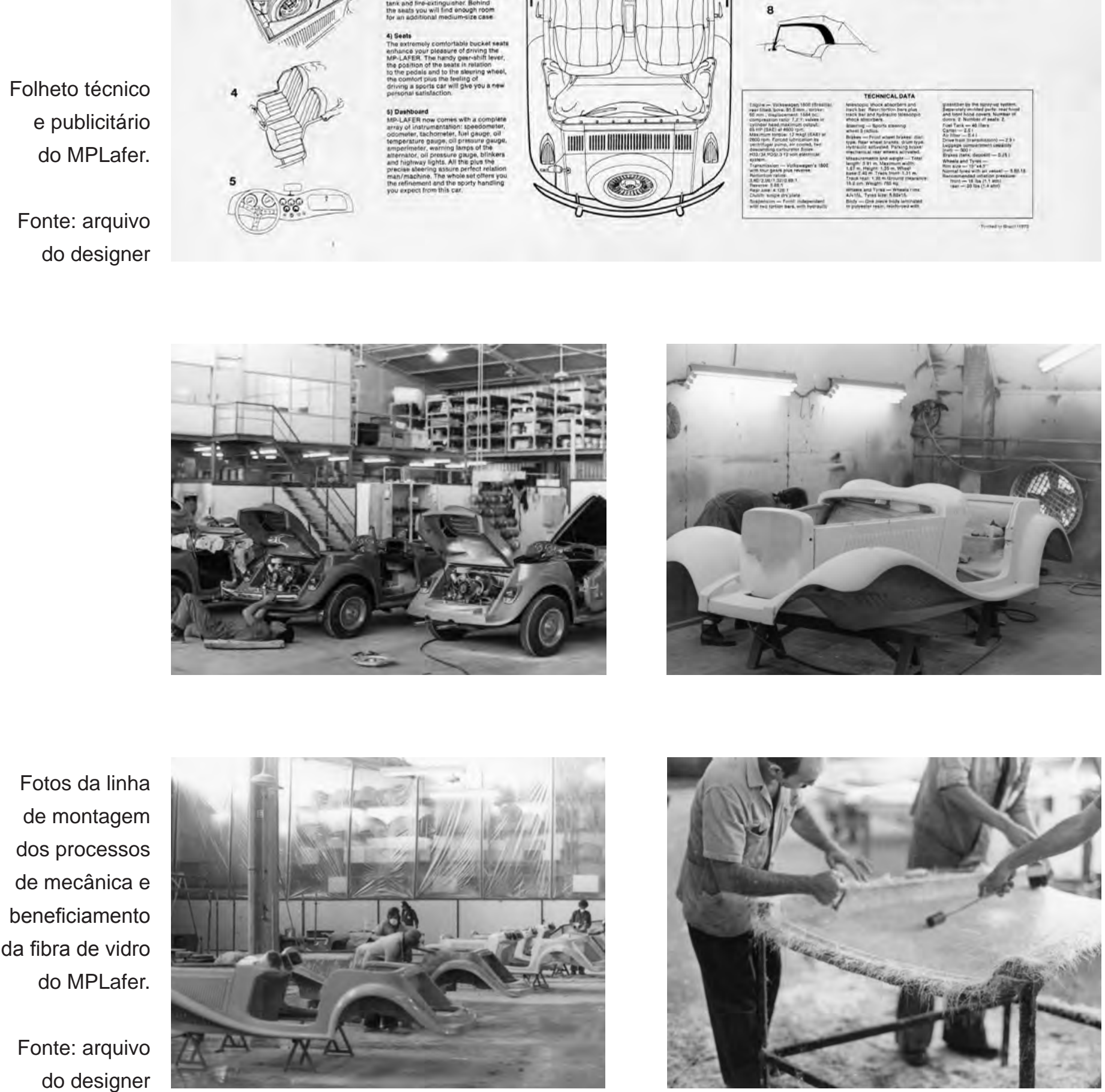


\section{Pássaro da Liberdade.}

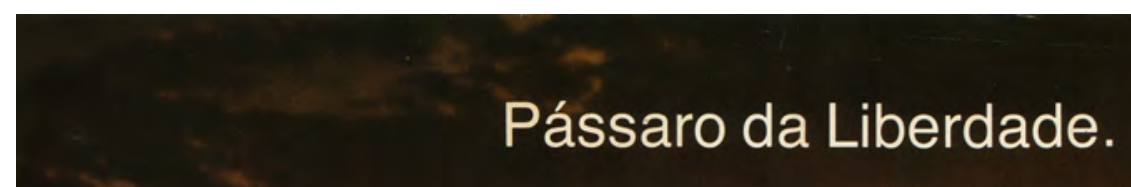

Anúncio

publicitário

impresso do

MPLAfer.

A descrição

categoriza o

automóvel

usando o jogo de

palavras que o

designam como

fora de série.

MP Lafer, o carro esporte brasileiro fora de série. 
Foto do processo de prototipagem do LL Lafer, dirigida pelo

engenheiro catalçao Rigoberto Soler

Fonte: arquivo do designer

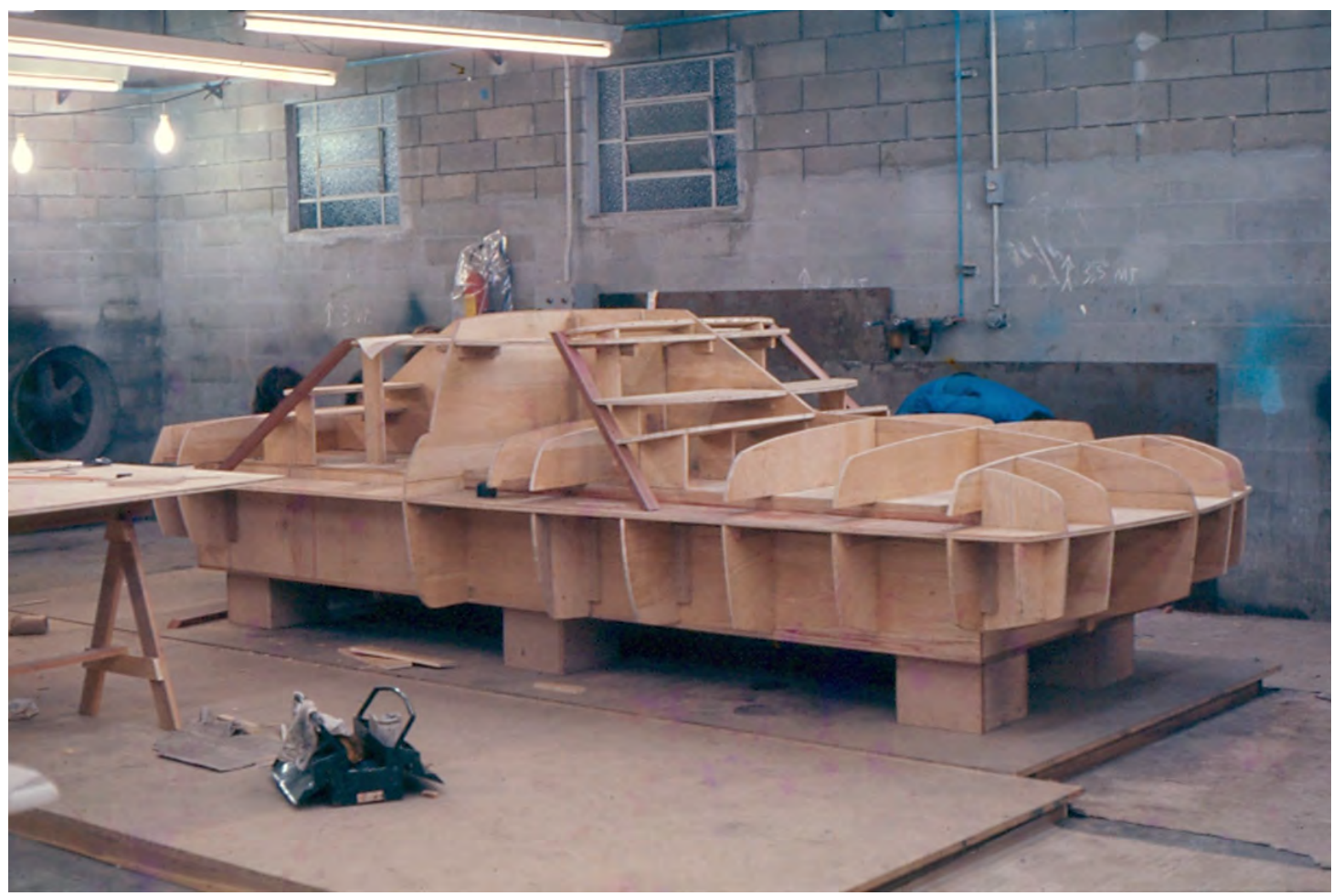

Foto do protótipo do LL LAFER .

Fonte: arquivo do designer

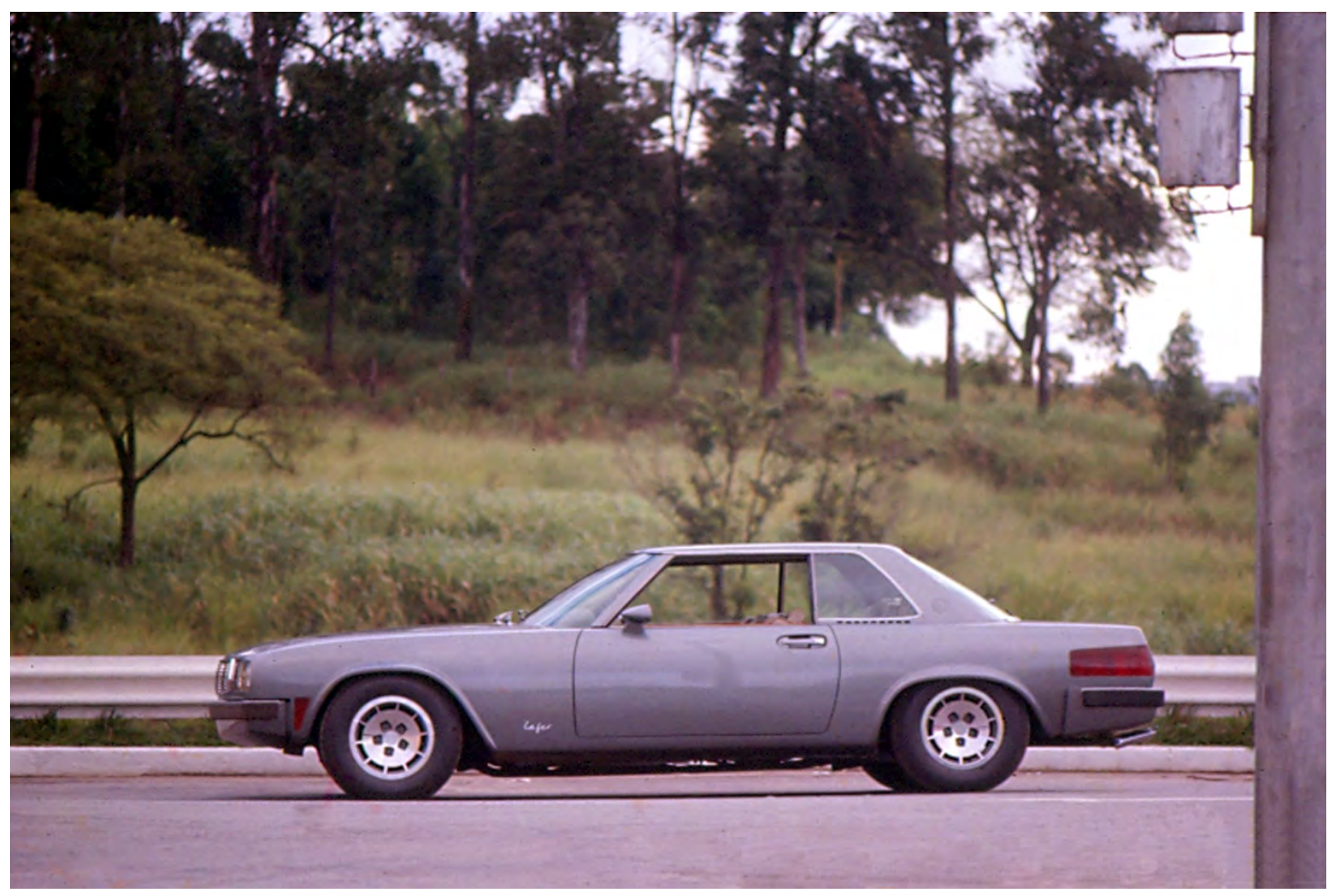


do século 20. Já em 1979, o próprio MP foi usado na produção do filme americano "007 contra o foguete da morte". É importante lembrar que, na mesma época, o PUMA, carro esportivo brasileiro de desenho contemporâneo, era produzido.

Para a Lafer ele funcionava como um chamariz publicitário. O que parece contraditório é que a lógica industrial de produção, tão perseguida pelo designer, neste caso, caiu por terra. O carro era produzido artesanalmente. Não havia nível industrial para a produção em série de um automóvel. O maquinário era completamente adaptado à produção de mobiliário. De qualquer forma, 1500 exemplares do MP - LAFER chegaram a ser produzidos. Alguns modelos chegaram a ser exportados para diversos países da Europa e para os Estados Unidos, em forma de "kit- car".

O MP Lafer teve ainda uma variação mais moderna o MP-LAFER TI. Em seguida, Percival lançou-se, com a colaboração do engenheiro Rigoberto Soler, no processo de desenvolvimento de mais um modelo de carro. Com o fechamento definitivo das importações de automóveis nos anos 1970, o designer aproveitou para desenvolver um equivalente nacional ao modelo Mercedes SLC. Assim surgiu o Lafer LL, cujo princípio de montagem seguia a mesma base artesanal de reaproveitamento de estrutura e mecânica pré-existente. No entanto, novidade tecnológicas e formais foram exploradas no projeto desse novo modelo, como a integração dos para-brisas à carroceria e a disposição de mostradores digitais com mostradores retro-iluminados acoplados ao volante do automóvel.

O Lafer LL acabou não saindo da fase de prototipagem, pelo alto custo de montagem e pela falta de escala industrial da própria MP Lafer para manter dois modelos de automóveis no mercado.

Hoje o MP-Lafer, único automóvel que chegou de fato a ser comercializado, converteu-se, assim como os sofás e poltronas, em item de colecionadores e auto-clubistas. 

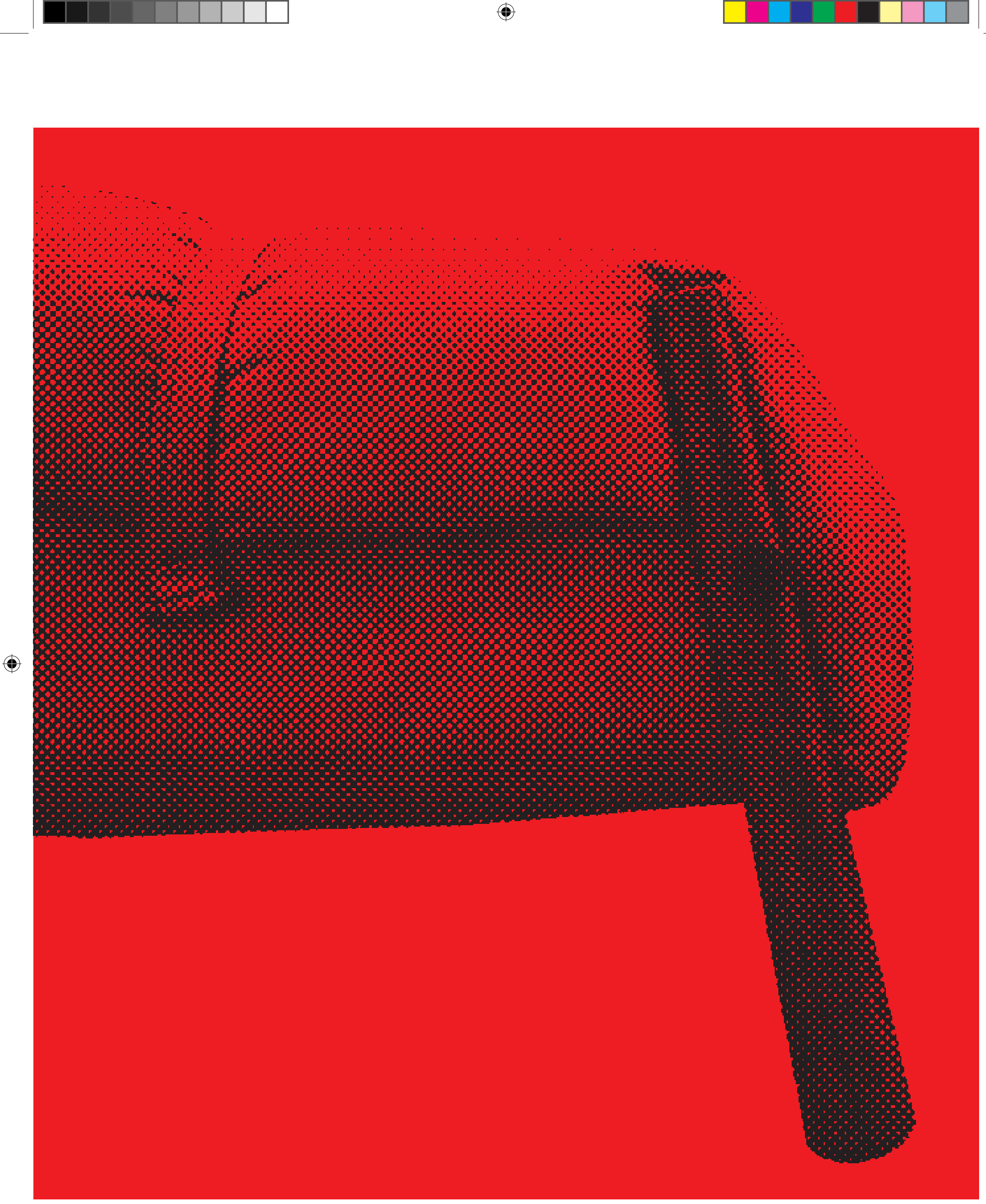

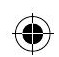


Pg. 74 - foto do conjunto MP81.

Fonte: arquivo do designer
O conjunto imagético apresentado a seguir compõe um panorama sobre grande parte da produção do mobiliário desenhado por Percival Lafer para a MP Lafer. O método que regeu o agrupamento das imagens busca concatenar o máximo de informações para tornar o pensamento de projeto e de produção legíveis ao olhar do leitor. Alguns aspectos foram identificados, e as imagens dos móveis e criações foram organizadas em sequência, a partir de aspectos comuns. Vamos apresentar quais são essas variantes para que a lógica de pensamento da disposição de imagens apresentada fique clara, e para que possamos lançar um olhar mais aprofundado, que ultrapasse as barreiras da classificação, a partir de um único aspecto. ${ }^{24}$

O fio condutor para a ordem de apresentação dos produtos é a decodificação do pensamento de projeto do designer, que seguiu, boa parte das vezes, as ideias de compatibilização e economia de escala. Economia de escala refere-se às estratégias adotadas para o aproveitamento máximo dos fatores produtivos envolvidos no processo de produção industrial, para que houvesse o aumento na quantidade total produzida, sem o aumento proporcional no custo de produção. Desta maneira, em economias de escala real, o custo médio do produto tende a ser menor com o aumento da produção.

A premissa do "bom projeto de design" para Percival Lafer era definido por meio de soluções que possibilitassem tirar maior proveito dos insumos e técnicas construtivas. Em empresas com grande escala de produção, o investimento inicial em projeto, tecnologia e desenvolvimento é difundido no crescente número de unidades fabricadas. Neste caso, o pensamento da escala produtiva é fundamental para a compreensão das soluções de projetos. Muitos dos produtos aqui apresentados, embora sejam aparentemente diferentes, possuem a mesma base de solução produtiva, mesmas técnicas construtivas, mesma concepção estrutural.

A criação de dispositivos projetuais contribuíram para a diversificação de soluções sobre o mesmo recurso técnico da seriação industrial. Lafer prototipou todas as peças. O projeto era realizado em tempo real. A partir de alguns esboços, o modelo começava a ser

24 Neste caso específico, não faz sentido reduzir a catalogação cronologicamente, formalmente ou pela nomenclatura dos objetos, pois esses dados estritos não apresentam coerência de análise sobre outras variantes mais importantes, como é o caso do processo criativo e construtivo das peças. Tentamos traduzir de forma fiel a linha de pensamento do designer, que conjecturava essas instâncias. 
montado. O desenho técnico executivo foi apenas empregado no projeto dos mecanismos de movimento e articulação, que requeriam precisão para serem executados. A prototipagem como forma de projetar delineia um modo de pensamento particular, em que a matéria, aliada às várias condicionantes produtivas e mercadológicas, conduz as definições de forma. Muitas peças tiveram mais de uma versão e variação no decorrer de sua fabricação.

Conforme os modelos forem sendo apresentados, os textos de referências ajudarão na identificação dos elementos comuns às linhas e coleções desenvolvidas pela MP Lafer. Percival estabeleceu uma lógica de pensamento que perpassa a maior parte de seus produtos. O raciocínio nem sempre é evidente, e se faz necessário apontar os caminhos e soluções adotadas, de modo a facilitar a compreensão de como projeto e produção em grande escala estavam relacionados.

A nomenclatura inventada pelo designer esboça a tentativa de organizar grupos e frentes de trabalho. Em entrevista concedida a esta pesquisa25, Percival descreve algumas das categorias criadas, revelando qual era, na partida, o intuito da classificação. A maior parte dos produtos, com exceção de algumas linhas especiais, realizadas em parceria com outras empresas, ou desenhos mais recentes, recebiam uma sigla composta pelas letras MP, de Móveis Patenteados, e um número de final ímpar. Essa premissa nem sempre foi seguida. Como podemos notar, muitas das sequências contêm lacunas, ou declinações, por variar um ou outro critério. O sistema não era rígido.

Os produtos que possuíam final 1 (MP1, MP11, MP21...) normalmente eram conjuntos de sala compostos por sofá, poltrona, mesa e componentes, destinados à exportação. São produtos que visivelmente podem ser classificados como itens de luxo, à medida que respondem às exigências de consumo de uma elite. Os materiais utilizados, formas e o escopo publicitário comprovam esse direcionamento. No mercado de usados, esses produtos são raros no Brasil. Contudo, podem ser encontrados a altos preços em antiquários internacionais. Os produtos da linha 1, na maioria das vezes, foram adaptados ao mercado nacional, por meio de simplificações formais. Essas adaptações nem sempre recebiam nova nomenclatura.

Os produtos de final 3 eram poltronas individuais. Grande 
parte dessa produção foi incrementada, à posteriori, com a versão sofá e complementos como mesas de apoio, conforme demanda dos compradores. Originaram também linhas mais populares de grande difusão. Alguns modelos foram exportados, outros nem chegaram a ser produzidos em larga escala. Fazem parte desta série algumas experiências formais com intuito publicitário.

As soluções modulares foram bastante exploradas pelo designer. A modulação foi encarada por Percival Lafer desde seu primeiro produto, nem tanto como um partido de projeto de componentes - esses pensados sempre em detrimento da escala industrial de produção vinculadas a seriação e mecanização -, mas como um partido combinatório dos produtos oferecidos. A criação dos módulos era designada a partir da integridade do produto final. Frequentemente, Percival partia da criação de uma peça, normalmente uma poltrona, que combinada a outras peças semelhantes poderiam compor um espaço múltiplo. Embora as peças fossem versáteis em sua concepção, a questão da escala dos móveis dificultava os arranjos. Os desenhos de formas muito robustas e volumosas contrapunham-se à ideia de modulação. $O$ designer investiu também em alguns poucos sistemas de componentes, como é o caso da linha Contempo e os paineis Woodstick, relacionados na compilação apresentada. Para esses produtos a nomenclatura designada terminava com final 5 (MP5, MP15...).

Croqui da poltrona Earth Chair, evidenciando o processo produtivo. A estrutura era inserida dentro da espuma quando injetada em molde de Fibra de vidro.

Fonte: arquivo do designer

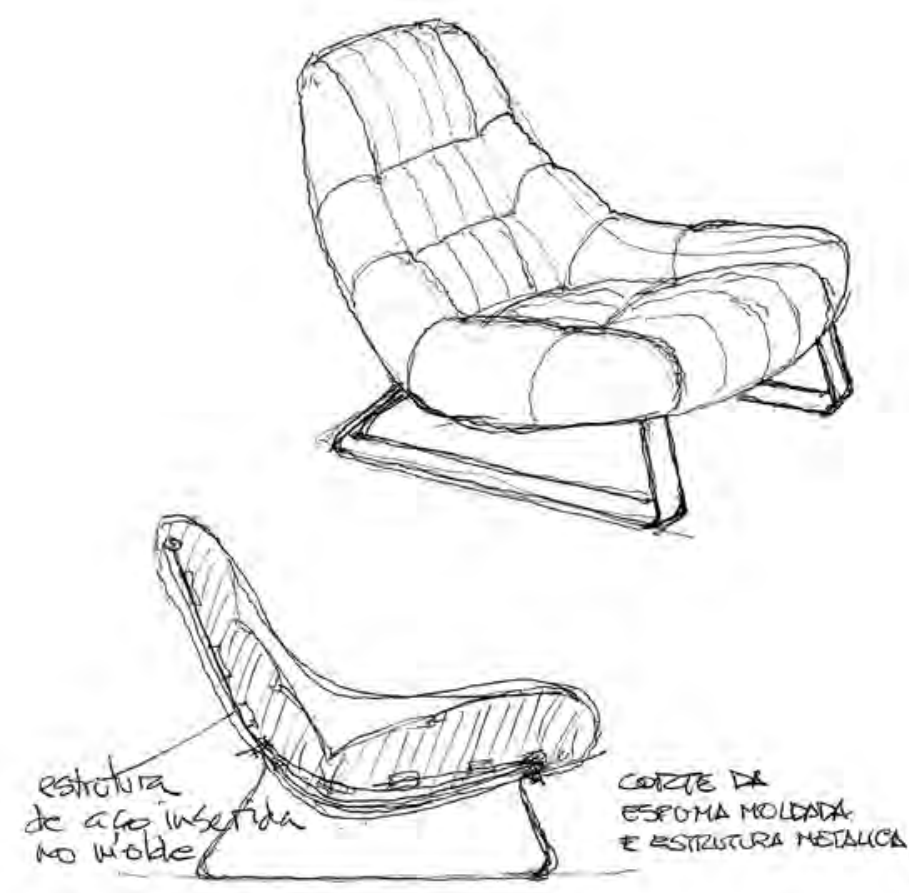


O final 7 foi destinado para nomear os sofás-camas. Esse segmento merece especial atenção, pois contém na concepção de seus mecanismos - desde o primeiro sofá-cama criado -, uma constante da criação de Lafer: as estruturas articuladas. Por meio da prototipagem e pesquisas no campo da engenharia industrial, o designer desenvolveu uma pesquisa prolongada de formas de articular e dar movimento a suas peças. Podemos notar no conjunto de sua obra que, mesmo quando os produtos não possuem articulações, eles foram pensados por meio de uma lógica articular de componentes. Não raro os móveis produzidos pela MP Lafer são desmontáveis e fruto de uma composição "articulada" de diversos componentes. O metal normalmente era usado como material de articulação. Os encaixes são mediados por peças soltas de metal, o que torna bastante característico o desenho de Percival. Quanto às estruturas de fato articuladas, se encontram presentes em muitos móveis que serviram de base para o aprimoramento técnico da produção das famosas cadeiras reclináveis e outros produtos que continuam a ser produzidos até hoje. Esses sistemas também foram usados no desenvolvimento de linhas hospitalares. A questão com o movimento é uma constante na produção de Lafer e estará presente na concepção dos carros e de alguns elementos arquitetônicos e equipamentos urbanos produzidos.

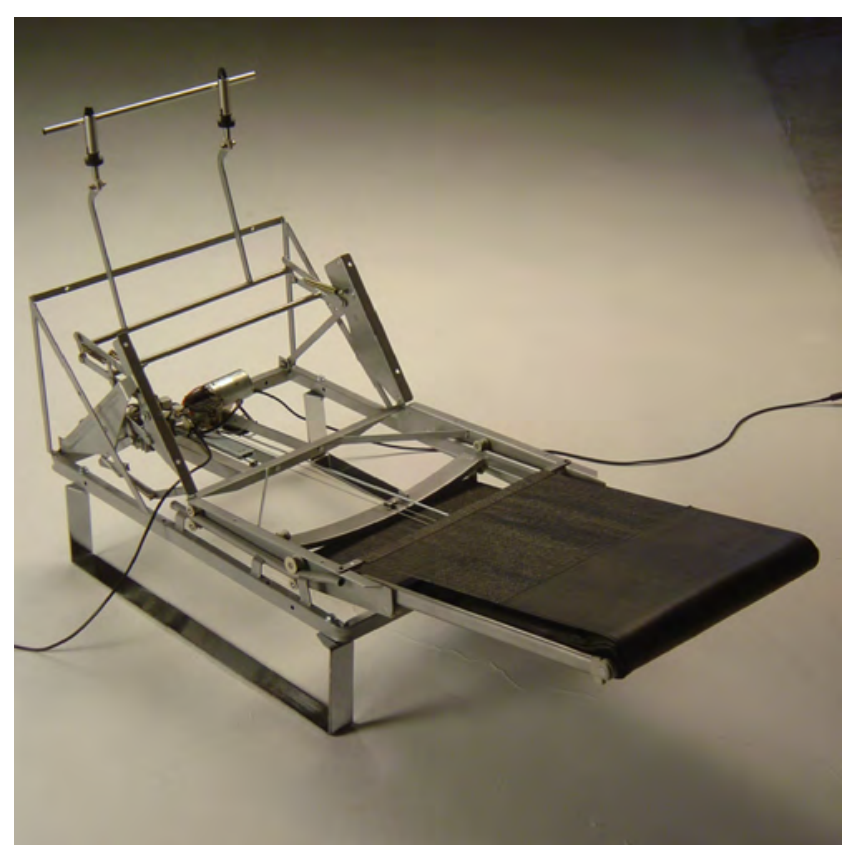

Estrutura articulável da poltrona reclinável Ion, projetada por Lafer.

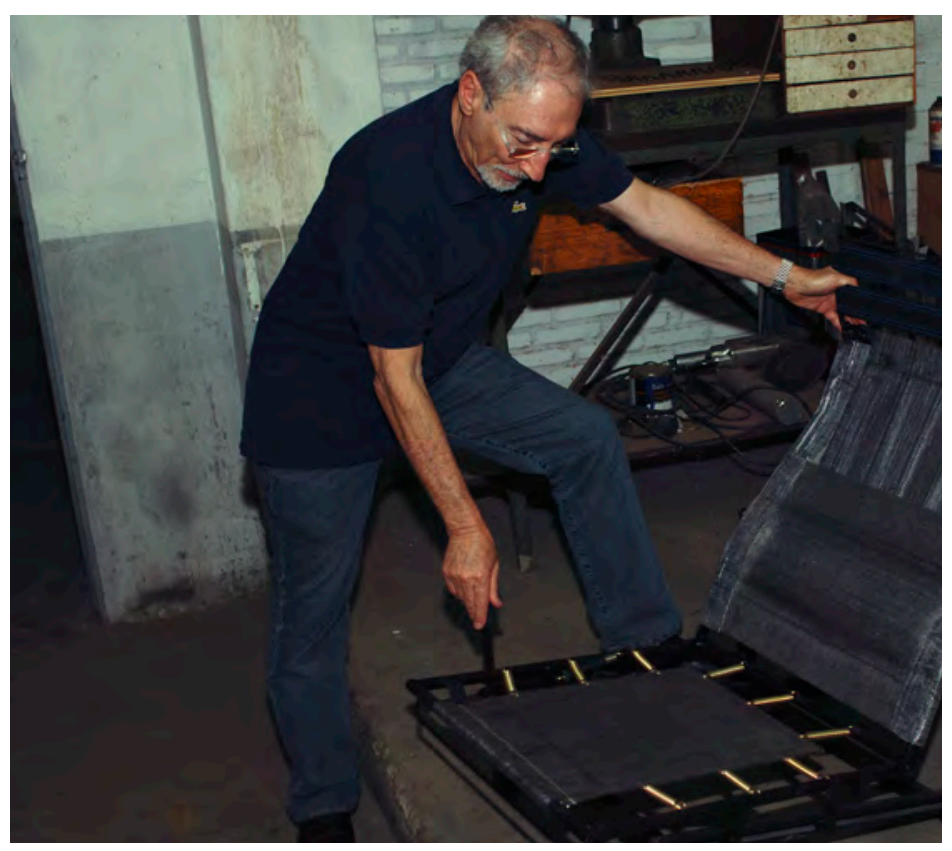

O designer testando o protótipo de umas das estruturas articuláveis que desenvolveu. 


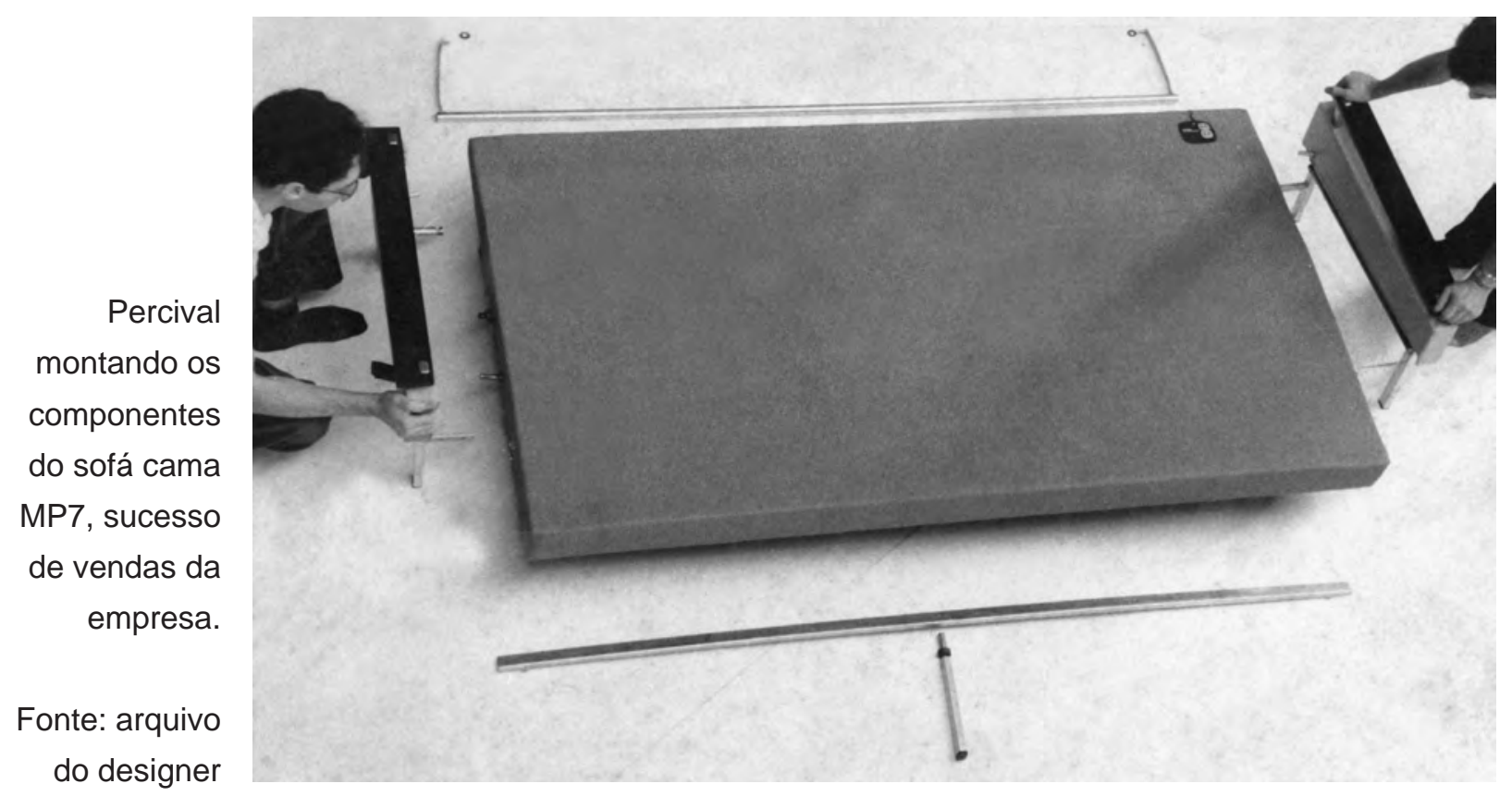

Por fim, as séries designadas pelo final 9 reúnem a produção popular, destinada a atender a classe média de poder aquisitivo baixo. Muitas das adaptações de móveis de outras linhas mais caras podem ser identificadas nesses produtos. $O$ desenho se mostra condizente ao gosto mais popular. Percebe-se isso no uso de cores e padrões de estofamento. Essas peças eram respostas às demandas de vendas identificadas por meio do diálogo com os representantes comerciais, que realizaram, de certa forma, uma pesquisa de mercado para a empresa. Com o tempo, a MP Lafer passou a contar com um setor de vendas e pesquisa de mercado, que alimentou as definições formais e produtivas dos produtos mais populares.

Sendo assim, apresentamos abaixo um panorama visual das principais criações que compõem a obra de Lafer. São 76 moveis escolhidos pelo conjunto de valores que o tornam significativos, dentro de cada categoria sinalizada. Ele nos ajuda a olhar de forma integral para o conjunto da obra do designer e perceber que, por mais que Percival tenha realizado concessões ao mercado e aos ditames da venda, condição sine qua non ao crescimento da empresa nos moldes pretendidos pelo designer, um estilo foi criado para além das soluções que ficaram presas às tendências lançadas pelo design do móvel moderno. 


\section{PRIMEIROS PROJETOS, PRIMEIROS PRODUTOS}

As sequências de primeiros móveis desenvolvidos por Percival obedecem a uma lógica cronológica. Eles foram todos desenvolvidos dentro da escala possível, a partir do maquinário que a empresa dispunha na época. Muitos dos elementos básicos de construção dessas peças eram produtos que existiam no mercado, como perfilados de metal, espuma, tecidos (que, segundo o designer, eram comprados nas lojas Pernambucanas).

O uso da serralheria como técnica também evidencia a simplificação da produção, já que o metal se apresenta como matéria mais dócil e de mais rápido beneficiamento do que a madeira, que, por sua vez, exige mais etapas de transformação. As primeiras experiências foram todas voltadas para o mercado nacional. O MP1, sobre o qual já falamos extensivamente, foi o motor experimental - gerador dos conjuntos que se seguem.

Esses primeiros móveis apontaram para diversas outras linhas que serão produzidas ao longo da existência da MP Lafer. Novos projetos foram criados a partir deles, implementando novas tecnologias e modos de produção. Apresentaremos cada um apontando para os móveis correlacionados por peculiaridades de projeto e produção. 
Primeira empreitada de Percival Lafer, o MP1 surgiu primeiramente como poltrona. Após o sucesso de vendas, Lafer produziu o módulo sofá, a contragosto. Ele diz: "A MP1 já havia sido pensada para funcionar como um módulo, o sofá era possível apenas pelo encaixe de duas poltronas. No entanto, o mercado consumidor tinha um problema com o assento divido em partes, sendo assim criei a variação do sofá de dois e três lugares. A mesa serviu apenas para ambientação e não foi produzida para venda."

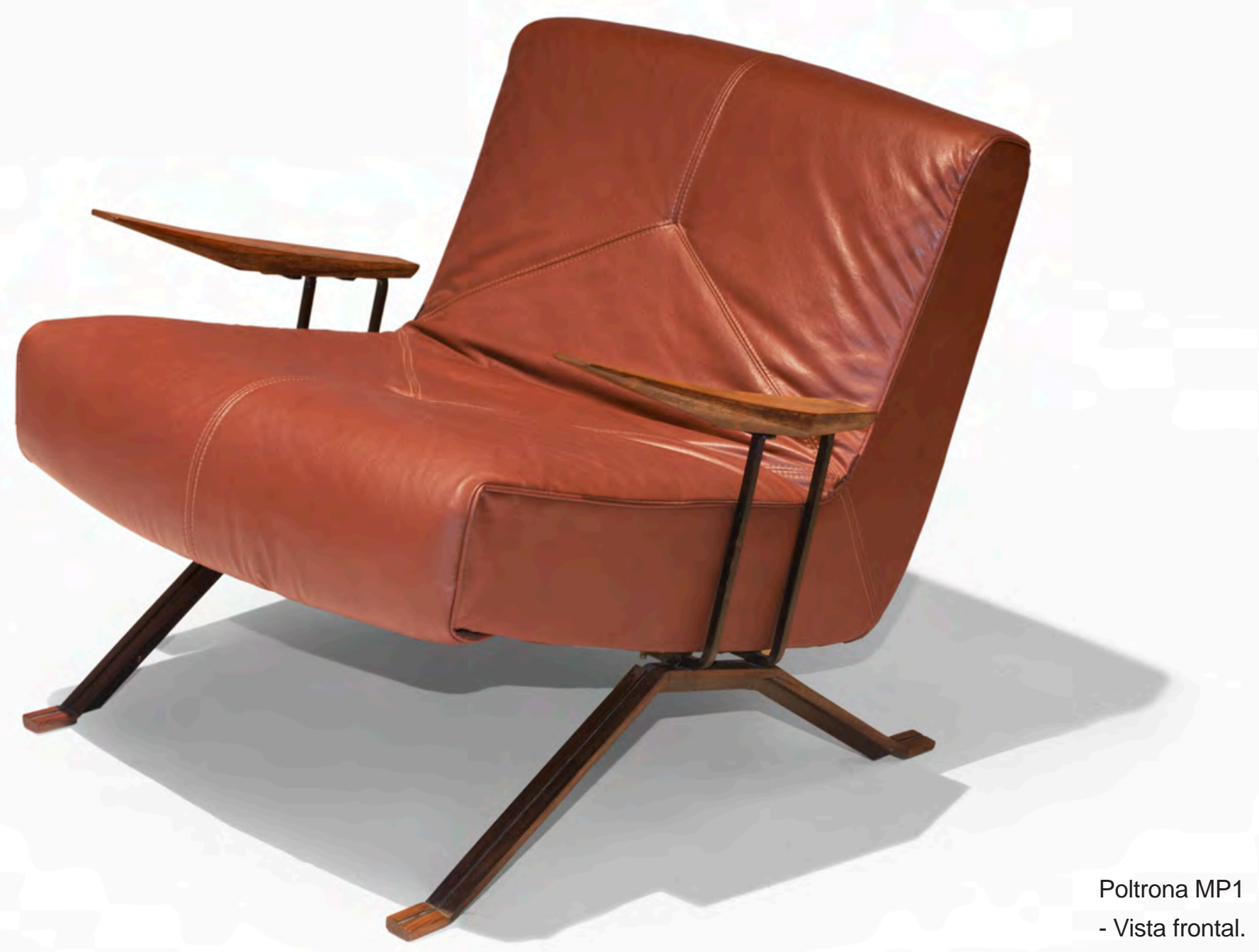

Fonte: arquivo do designer 
Croquis da poltrona MP1, desenhado por Percival Lafer, com detalhmento do perfil metálico revestido em madeira maciça

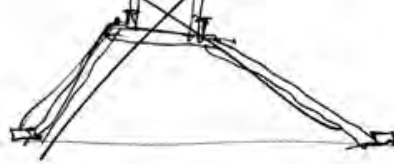

Fonte: arquivo do designer
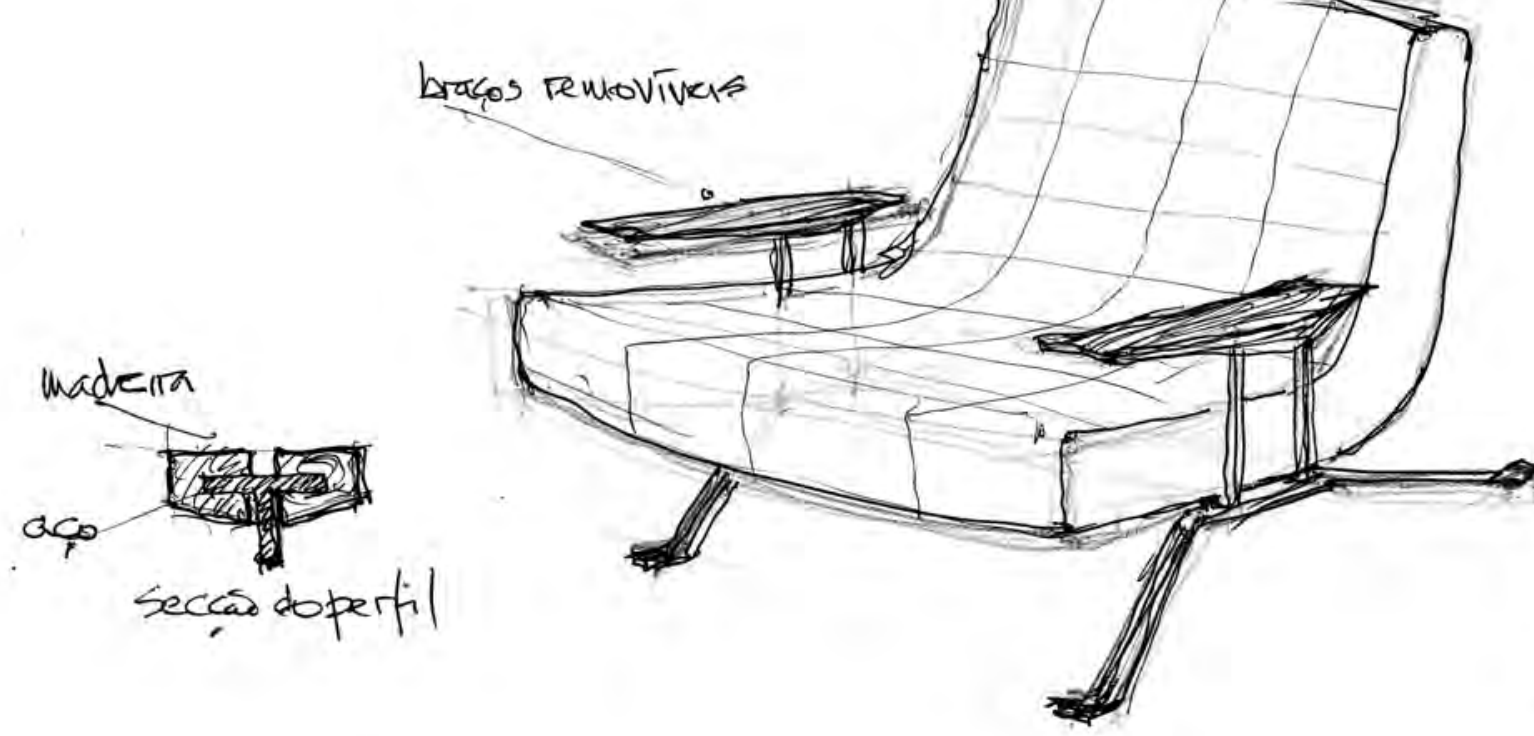

MP1

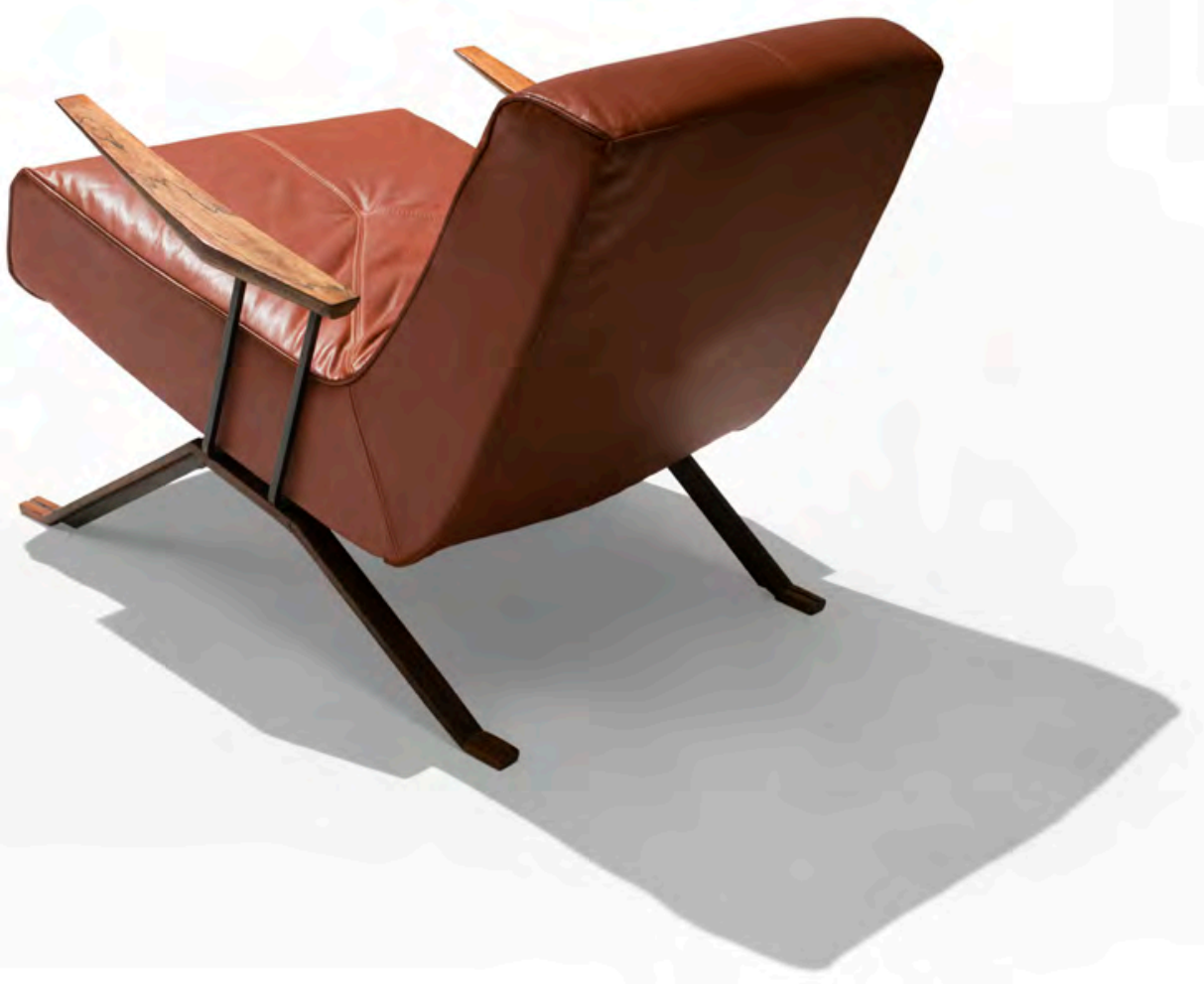

Poltrona MP1 -

Vista traseira

Fonte: arquivo do designer 
A solução é bem simples. O móvel é composto de uma estrutura metálica de perfis " $T$ " revestidos em madeira. Dessa estrutura saem os suportes tubulares, também em metal, sobre os quais eram aparafusados os braços de madeira esculpida. O estofado era composto de um quadro em madeira que suportava o assento formado por percintas de borracha. Essa solução substituía o uso antigo de molas com enchimento de crina e algodão, comum na tapeçaria da época. A espuma única do assento e encosto era cortada e revestida de tecido. Uma técnica de encapamento foi especialmente desenvolvida por Lafer para que as padronagens não distorcessem durante o processo de colagem do tecido à espuma. O pano era colado sem cortes sobre o estofamento. Com a ajuda de um grande bastidor, pousava o revestimento de forma completa, proporcionando a maior área de contato possível. Algumas peças foram produzidas em jacarandá, madeira que foi logo substituída pelo pau-ferro, e pelo jatobá tingido (para mimetizar o jacarandá), por questões econômicas e dificuldade de fornecimento da madeira.

A primeira leva de poltronas foi vendida à loja de móveis Decorações Sida, fundada por imigrantes judeus, e estabelecida até hoje na Rua das Palmeiras, na Santa Cecília.

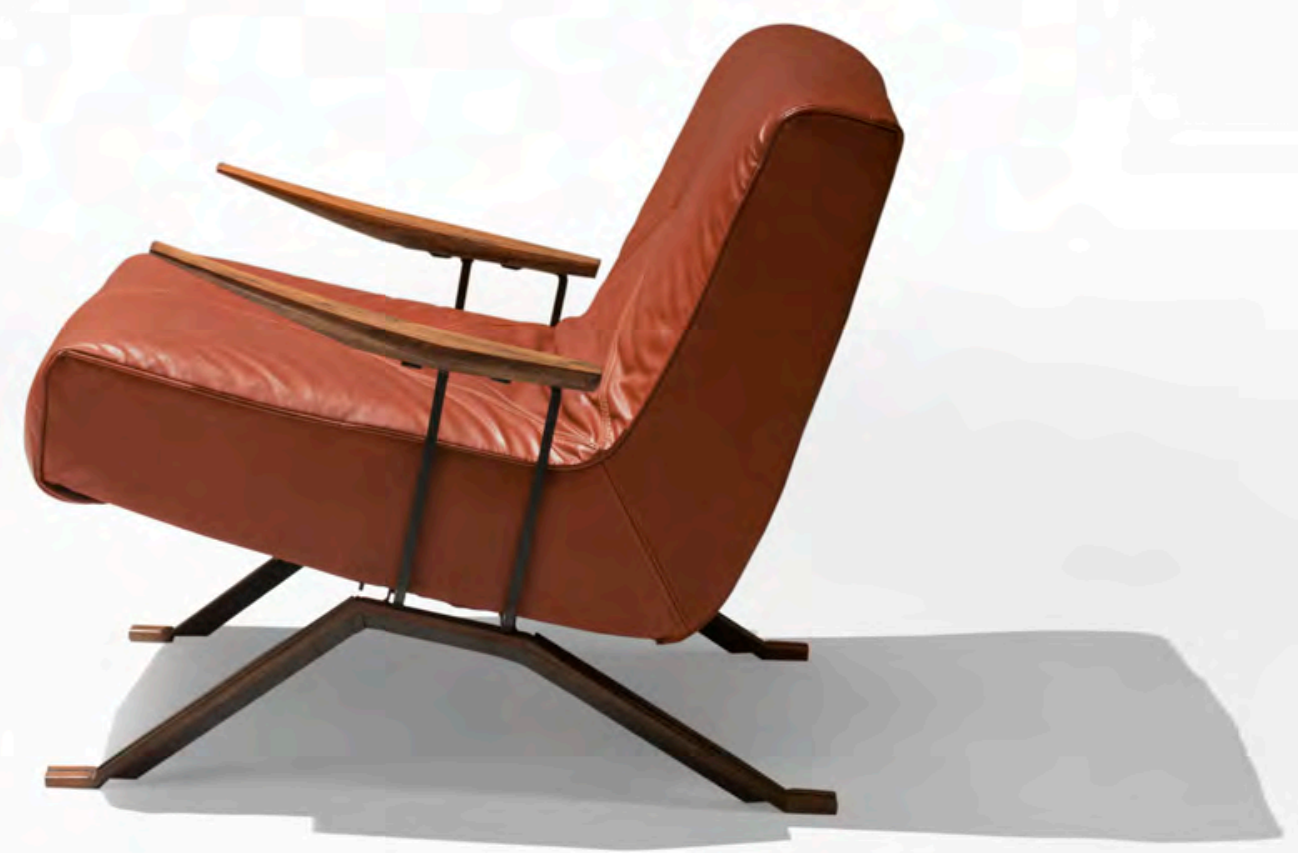

Poltrona MP1

- Vista lateral.

Fonte: arquivo do designer 
Manequim posando com a poltrona MP1 para divulgação

Ambiente decorado com a poltrona MP1, prtimeira criação do designer, 1961

Fontes: arquivo do designer
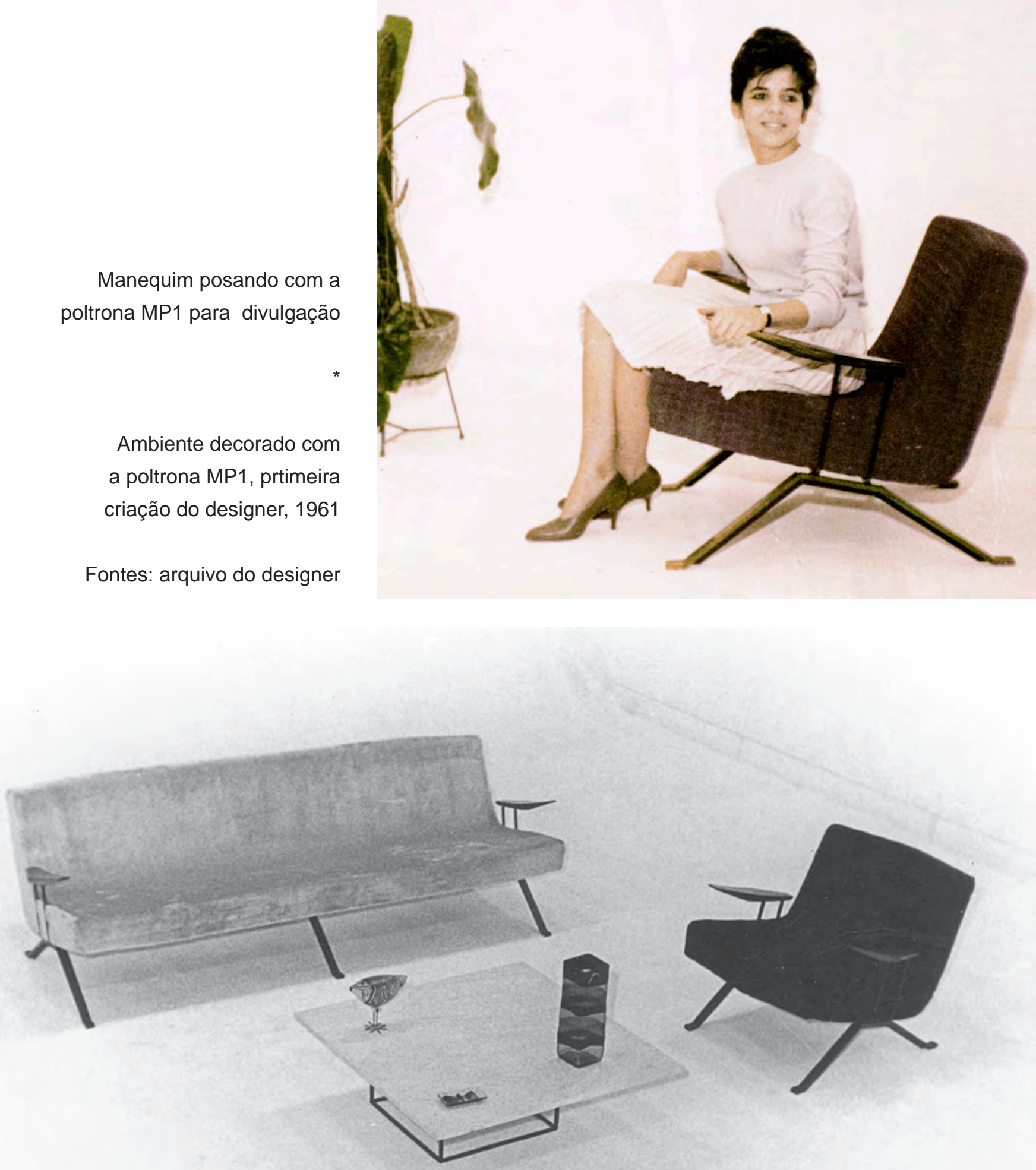


\section{MP3 - 1962}

O conjunto de sofá e poltrona MP3 foi uma criação conjunta entre Percival Lafer e seu irmão Oscar Lafer. O partido continua sendo o de uma estrutura em serralheria revestida. $O$ assento ganha uma nova forma mais prismática, embora apresente a mesma solução técnica do MP1, no uso das percintas, estofado em espuma e revestimento colado. As formas são mais simplificadas, como se nota claramente no desenho do braço. $O$ conjunto de assento e encosto pousam em uma estrutura central que se apoia no contraventamento dianteiro, aparafusado nos quadros laterais.
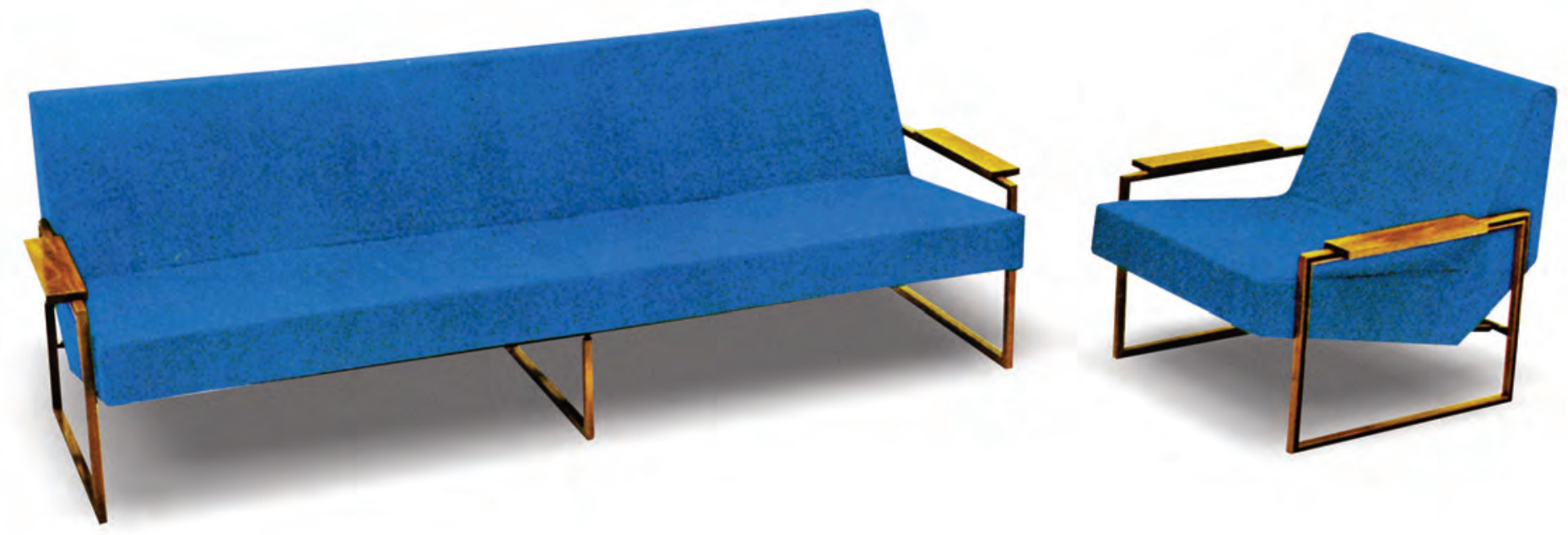

Poltrona MP3 -

Vista do conjunto.

Fonte: arquivo do designer 


\section{MP5}

O conjunto MP5 é uma variação simplificada do MP3. A estrutura continua praticamente a mesma. O conjunto de estofamento, de forma prismática, foi substituído pela solução adotada no MP1. O conjunto recebe também um conjunto de mesas laterais e de centro muito leves, que repetem, em escala, a forma estrutural lateral da mesa, em cintas que seguram o tampo. Os tampos eram revestidos em pau ferro. As estruturas gerais perdem os detalhes de ranhuras e rebaixos existentes nas peças do conjunto MP3.

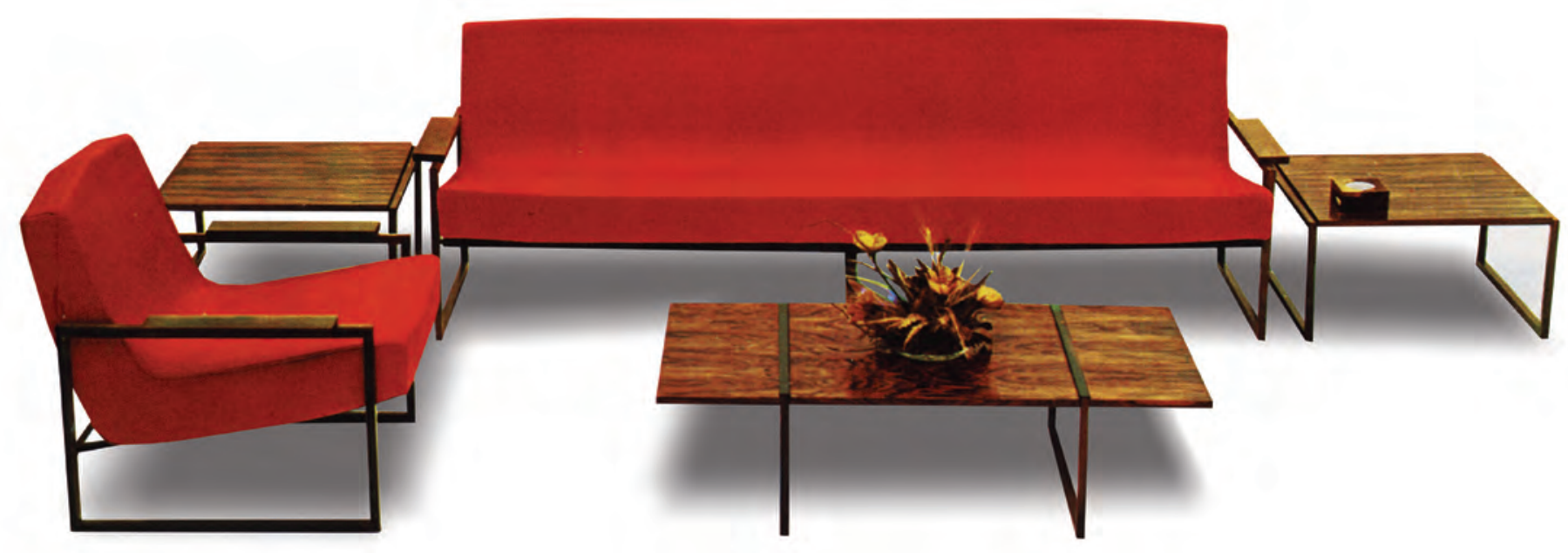

Poltrona MP5 -

Vista do conjunto.

Fonte: arquivo

do designer 


\section{MP9}

O MP9 é um conjunto de sofá e poltrona luxuosíssimo. Ele será pensado na mesma chave de independência dos elementos do móvel aplicado ao MP7, exposto mais adiante, o que libera a produção em várias frentes. A estrutura do pé, independente dos outros elementos, é composta por duplas de barras chatas e vergalhões em aço polido, unidas por parafusos sextavados. Essa estrutura será usada tanto para o conjunto de assentos como para as mesas. O elemento só varia na inclinação de sua trava superior, o que traça uma unidade no campo estético e produtivo. A trava superior para as mesas é horizontal, enquanto que nas poltronas e sofás foi inclinada para acompanhar e dar sustentação ao braço. O braço é uma peça de madeira independente com topo revestido em couro, e laterais em jacarandá. Ele esconde todo o sistema de sustentação da peça. Dois pinos incluídos abaixo dele, dão sustentação ao mesmo, conferindo grande leveza à peça.

O estofado parece flutuar, fixado a partir da estrutura atrelada ao braço. O estofado é idêntico ao do MP1, recebendo agora revestimento em couro capitoné e enchimento de Plastispuma Trorion, tipo de espuma usada na indústria automobilística. $\mathrm{O}$ acabamento é muito refinado. A folha de jacarandá, antes de ser colada na estrutura do mesmo, recebia um pesponto branco. Essas linhas causam, a priori, uma ilusão de ótica, tridimensionalisando o braço em prisma, ao mesmo que simula um processo de fixação da folha de madeira sobre seu plano. $O$ conjunto tem uma outra versão, com revestimento em couro repuxado em linhas horizontais pespontadas.

Versão da poltrona MP9, com revestimento em courino e detalhes realizados por merio de solda eletrônica

Fonte: arquivo do designer

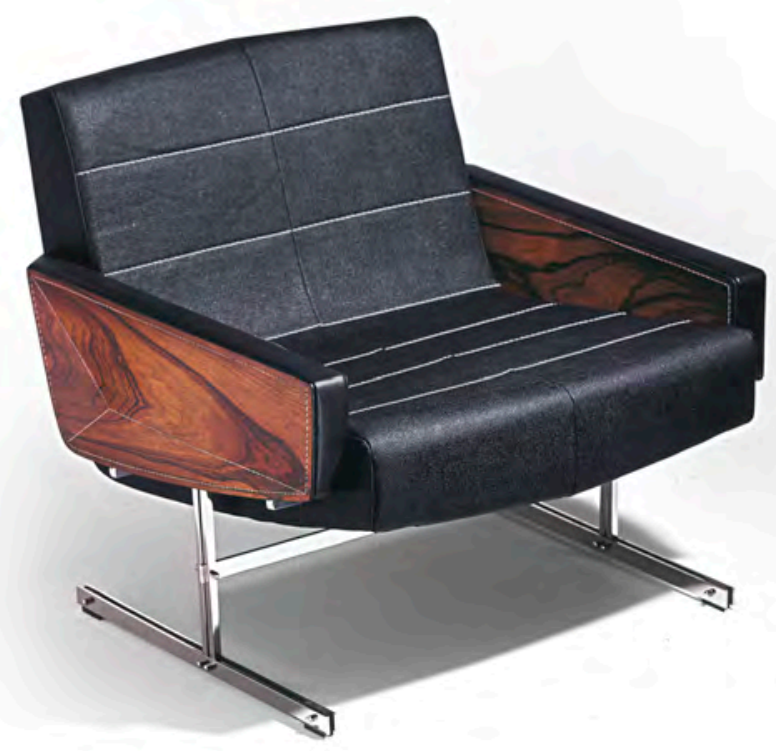

Conjunto M9 ambientado

Fonte: arquivo do designer 

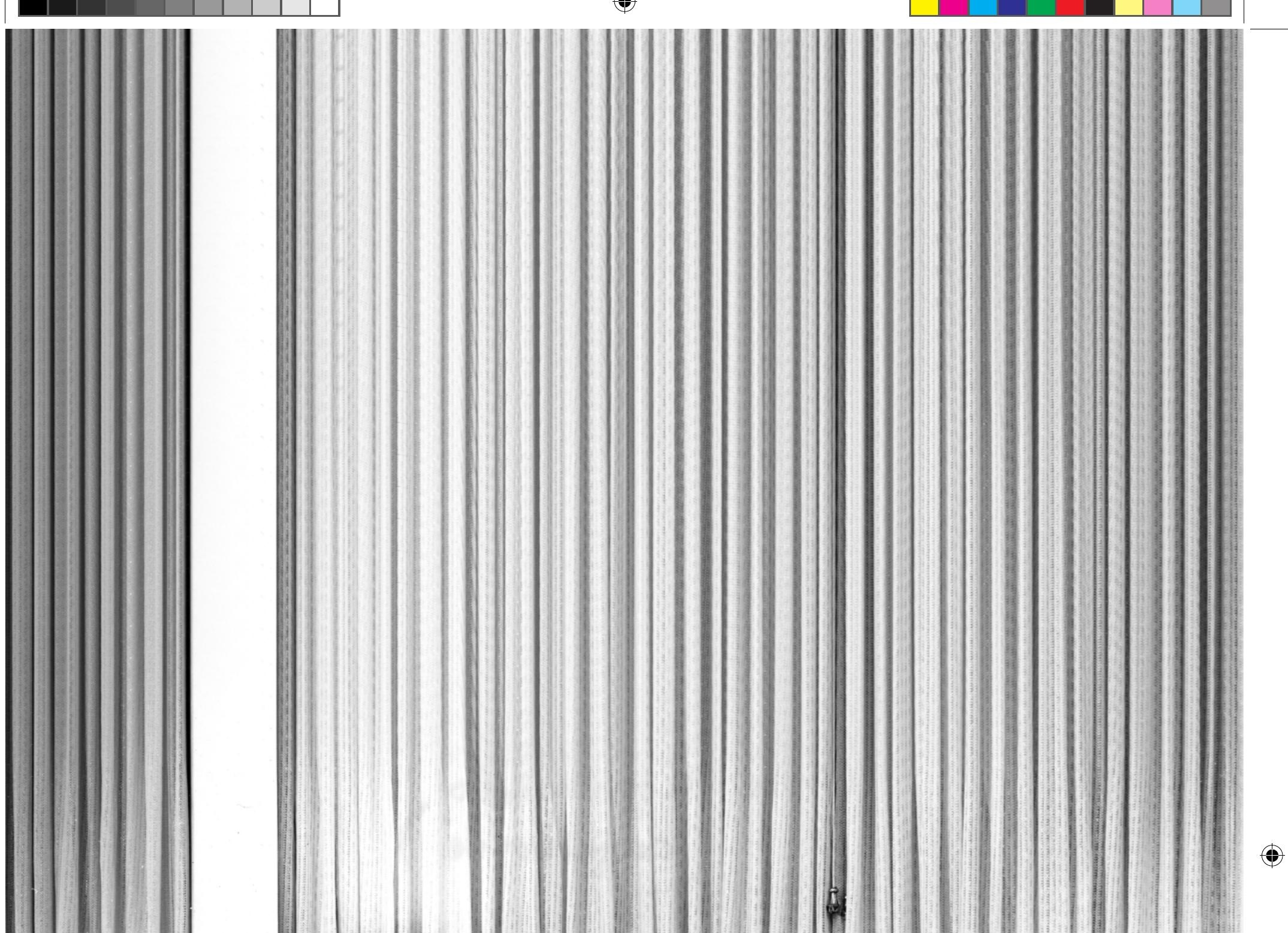

(n)

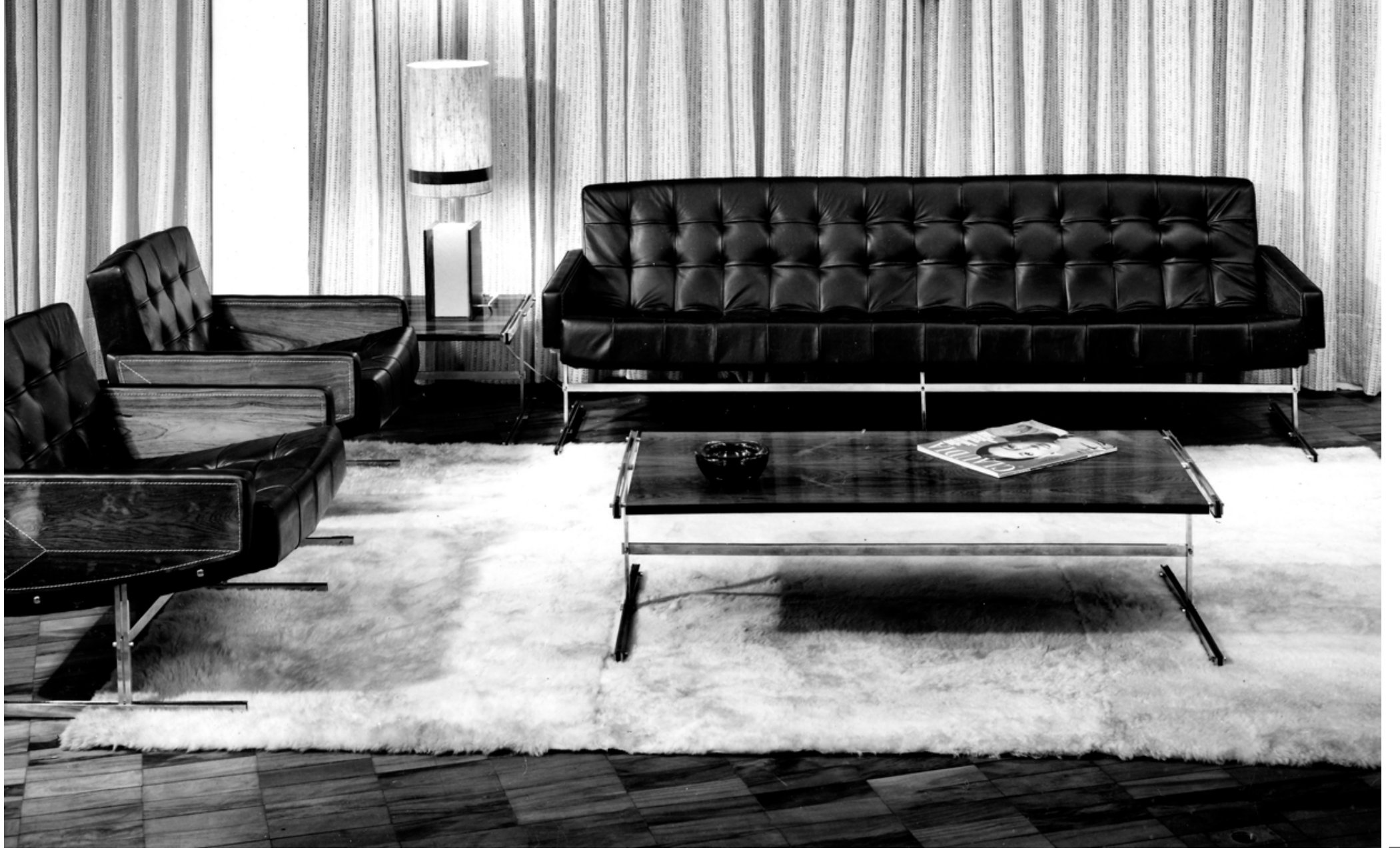

$\theta$ 
Croquis de Percival Lafer sobre a poltrona MP9

Fonte: arquivo do designer

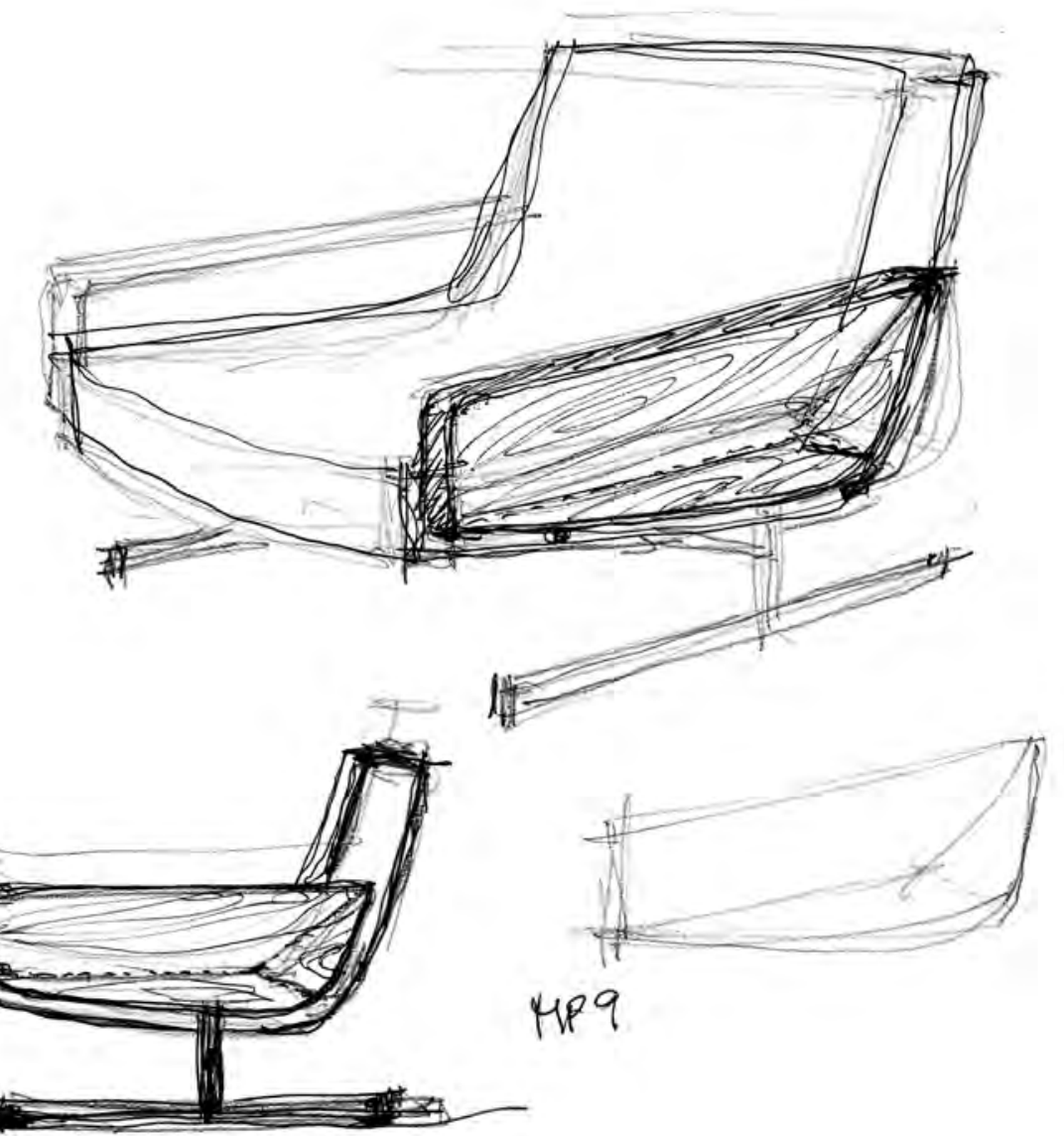

$\oplus$

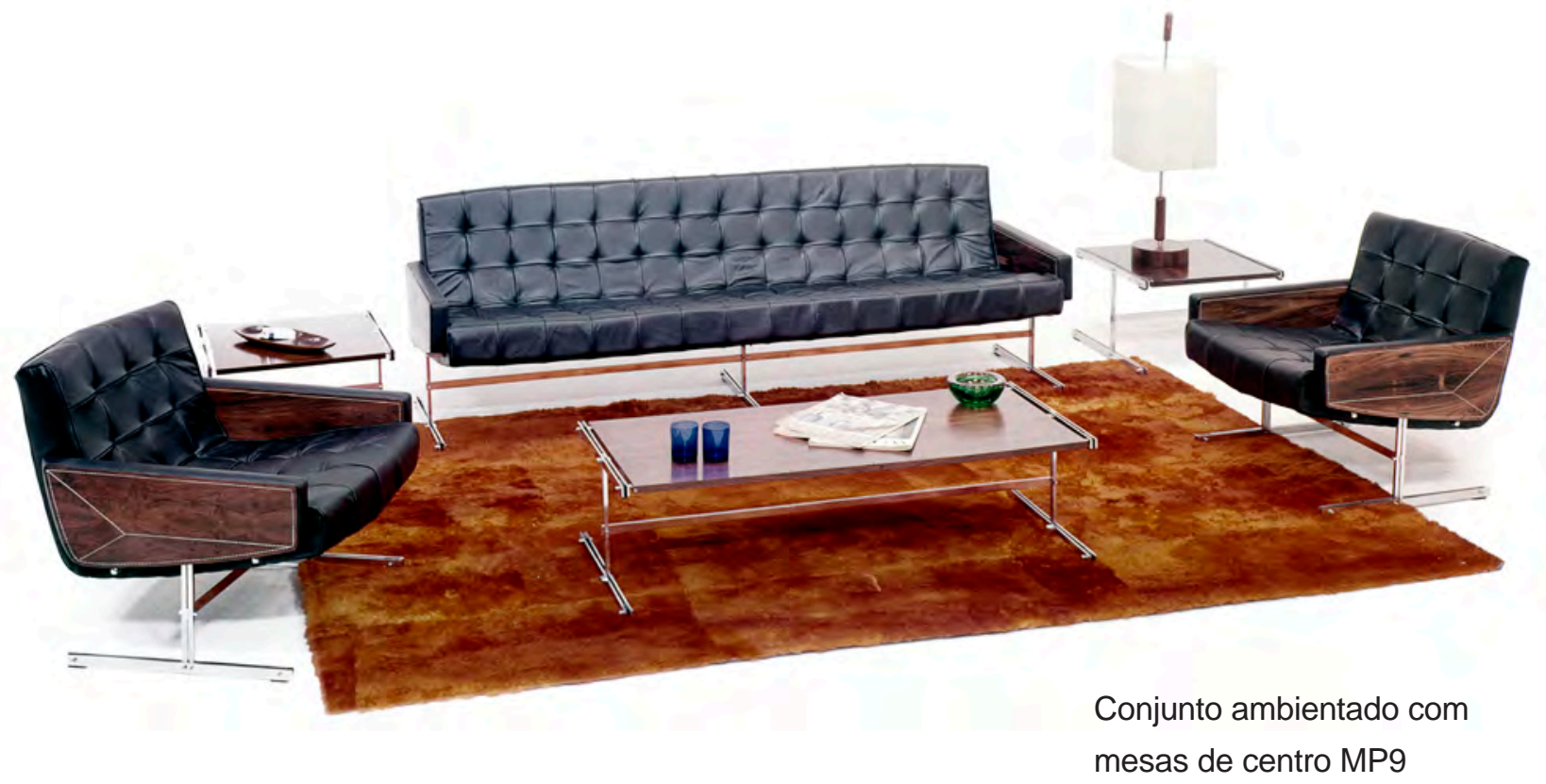

Fonte: arquivo do designer 


\section{MP11}

O MP 11 pode ser considerado o primeiro conjunto de sofá e poltrona que deu origem a uma série e outras linhas, mais simplificadas. De estrutura simples, derivada de certa maneira do MP7, esse conjunto propõe um desenho em que os pés estão montados por meio de parafusos nos vértices do braço e encosto. Aqui já vemos uma evolução no pensamento do estofado. Ele foi dividido entre assento e encosto. Nos modelos anteriores, o uso de uma peça única foi bem explorado. A peça única de estofado apareceu durante toda a produção de Percival, no entanto, restrita ao móveis da linha 1 e suas adaptações para o mercado nacional.

Esse conjunto, embora simples, é rico em detalhes. O pé em alumínio está encaixado em rebaixos feitos nos braços revestidos de material vinílico. Pela primeira vez, Percival fez uso da solda eletrônica na substituição das costuras no estofamento. Os revestimentos vinílicos são unidos com solda eletrônica, uma tecnologia de última geração, usada pioneiramente pelo designer. O resultado, nas palavras do próprio designer, é "um aspecto mais elaborado na superfície do revestimento vinílico, sem o custo elevado de costuras tradicionais26. O braço, desta vez, tem papel estrutural, contraventando a leve estrutura. O estofado é preso internamente pelas travas de madeira, visíveis na lateral no móvel. O desenho da trava é muito elegante com o chanfro em parte posterior no intuito de maior resistência estrutural.

Conjunto MP11

Fonte: arquivo do designer

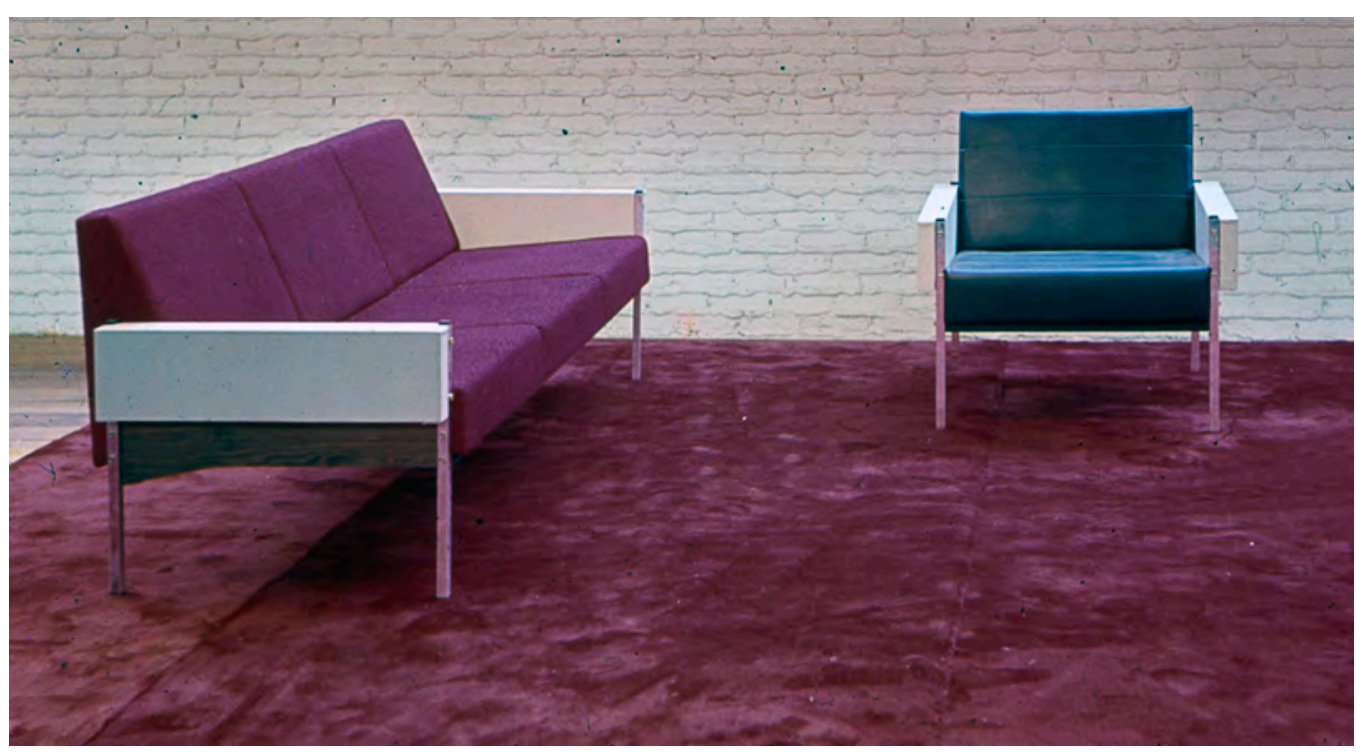




\section{MP13}

Este conjunto de sala inaugura uma nova forma de Percival Lafer pensar seus móveis. Embora inspirado na poltrona mole de Sergio Rodrigues, ele se estrutura de forma completamente distinta. Aestrutura é completamente independente. A base de madeira e os braços em madeira maciça (na versão popular destinada ao mercado nacional eles serão não serão produzidos em madeira maciça, mas sim em compensado revestido) são ligados por peças metálicas e parafusos, que para ficarem aparentes recebem um copinho metálico que os revestem. O estofamento é o mesmo do MP1, mas agora com um forro em pluma de poliéster que o deixa mais fofo, dando a impressão de conforto mole. As asas do estofado são removíveis e estão presas aos braços por meio de uma alça feita do mesmo material de revestimento do estofado. Os braços possuem regulagem para duas alturas.

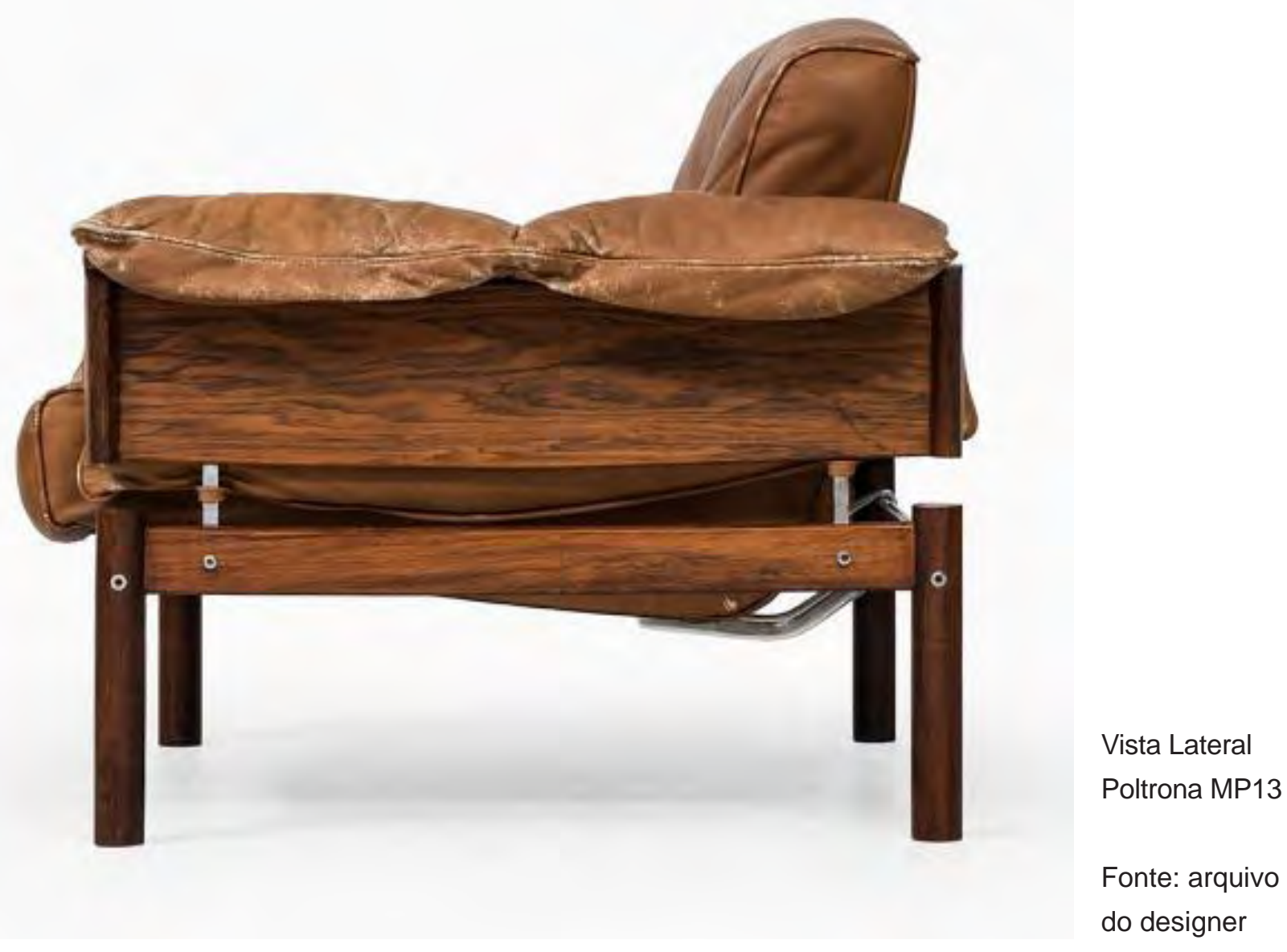




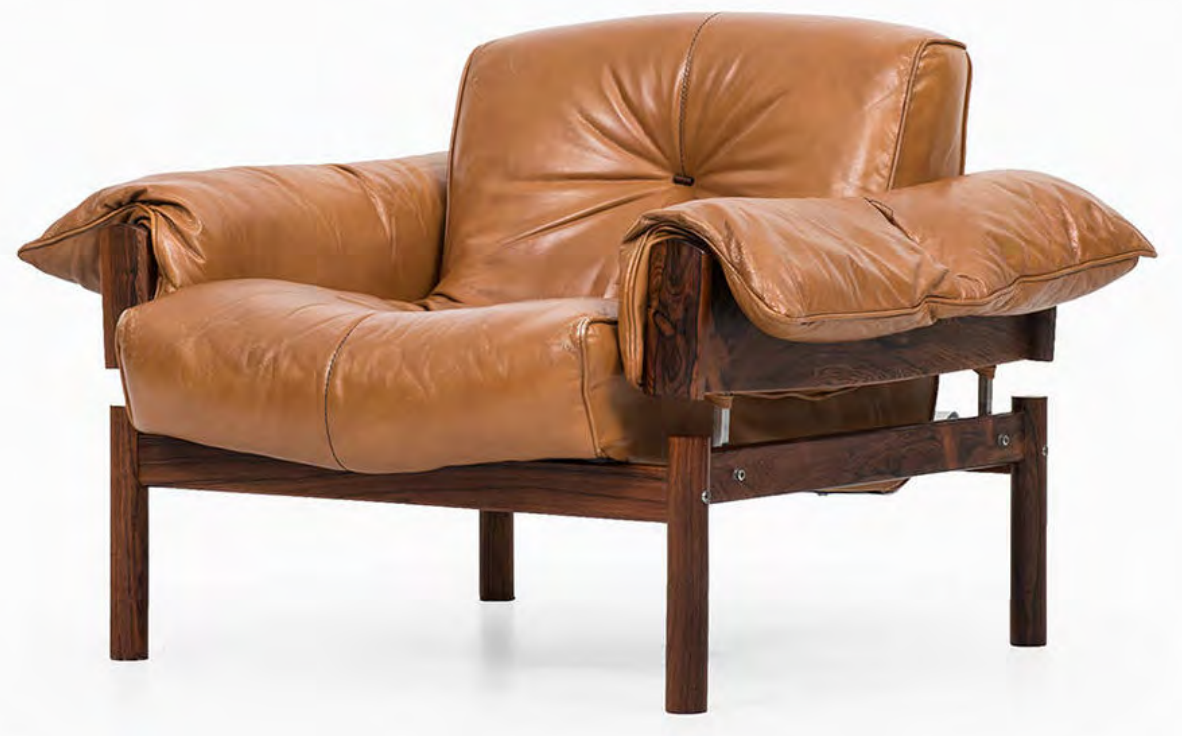

Poltrona MP13

Fonte: arquivo do designer

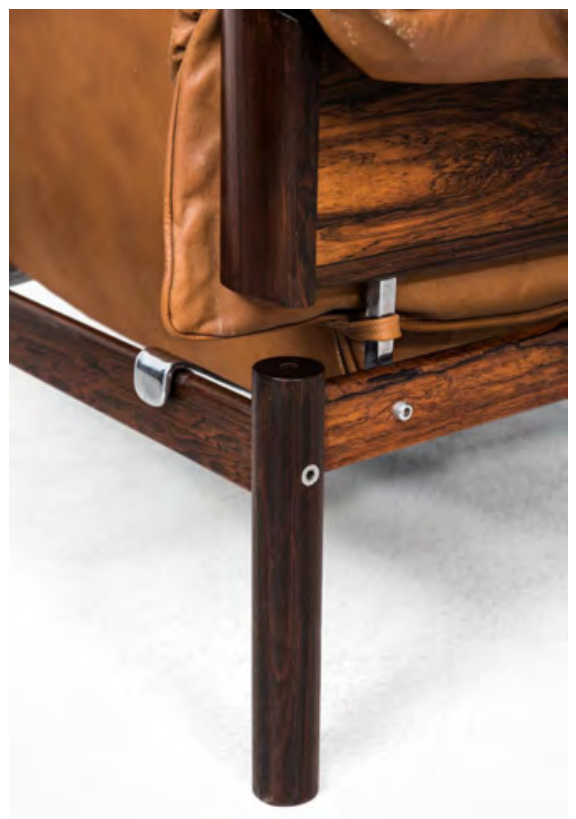

Detalhe fixação braço e estofado

Fonte: arquivo do designer

A estrutura base, feita com tarugos redondos de madeira maciça montados com travas de perfil retangular, servem para a construção da poltrona, das mesas e do sofá de forma estendida. O assento/ encosto único pousa sobre a base, por meio de patas metálicas. O revestimento usado é o couro e, em opção mais popular, o courvin. Os repuxos são arrematados com botões em formato de "cavilha" de madeira maciça. Todo o conjunto foi fabricado para exportação e para o mercado nacional em jacarandá maciço. O jacarandá foi pouco usado por Percival, sendo substituído pelo jatobá tingido.

Diversas outras linhas de mobiliário seguiram o partido projetual de uma base em madeira ou metal, sobre a qual apoiam-se o assento estofado. Outro partido que se reproduz em muitas outras linhas são as peças de junção metálicas. Os elementos serão, na maioria das vezes, unidos por meio de peças metálicas que acomodam perfeitamente os elementos entre si. Parafusos, botões e arremates de estofado passam a integrar as preocupações de acabamento do designer. Como o diabo mora no detalhe, Percival conseguiu desenvolver uma linguagem própria de tratamento, um estilo, dedicando-Ihes valor integrado ao projeto. 


\section{MP 19}

As peças que compõem o MP19 são fruto de um amadurecimento do desenho do conjunto MP13. O princípio continua o mesmo: base estrutural em madeira, junções e complementos metálicos e estofamento em couro. No entanto, há alterações substanciais. As travas da estrutura de base e braços foram duplicadas e unidas por perfis redondos de aço que seguram as percintas de borracha vulcanizada preta. O estofado deixou de ser uma peça única e passou a ser dividido em duas partes - assento e encosto - que, ao invés de se apoiarem por meio das patas metálicas sobre a estrutura, passam a ser sustentados pela sequência de percintas. No desenho, as percintas eram elevadas até a altura do braço, o que proporcionava respaldo ao encosto, além de movimentar criando um ritmo, as costas do conjunto.

O sistema criado por meio de perfis metálicos e percintas foi utilizado em alguns outros modelos da MP Lafer, bem como o novo formato de estofamento, o que pode ser notado especialmente nos primeiros conjuntos de luxo destinados à exportação. O MP51, por exemplo, embora sob outra concepção formal, funciona com uma base feita de um quadro de perfis redondos de aço e uma trama de percintas de couro. O estofamento utilizado nesse conjunto, tirando a adição dos braços, é exatamente o mesmo, com outro tipo de recorte e acabamento do couro. Os braços ainda recebem uma capa de acabamento, no mesmo material utilizado no estofado (couro ou courvin), gerando maior conforto ao apoio do braço.

As mesas laterais e centrais também foram minimamente alteradas. Diferentemente do conjunto MP13, as atuais mesas recebem calços de madeira entre a estrutura e o tampo. Assim a pedra fica solta da estrutura de base. Esse artifício dá a impressão de flutuamento e leveza aos tampos.

Conjunto MP19 ambientado

Fonte: arquivo do designer

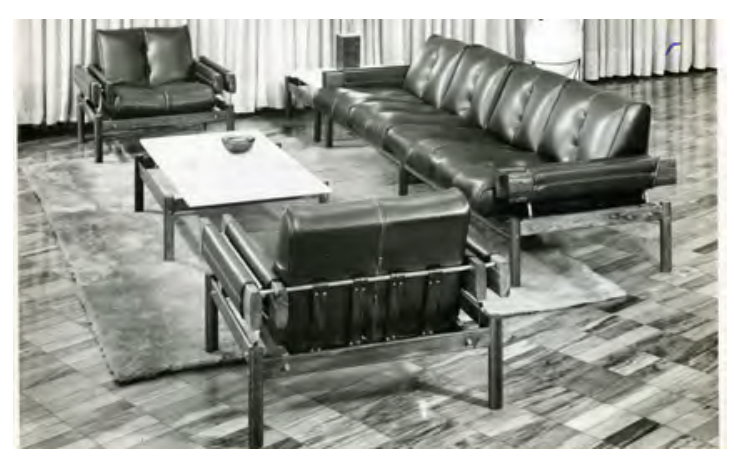




\section{MP-19}

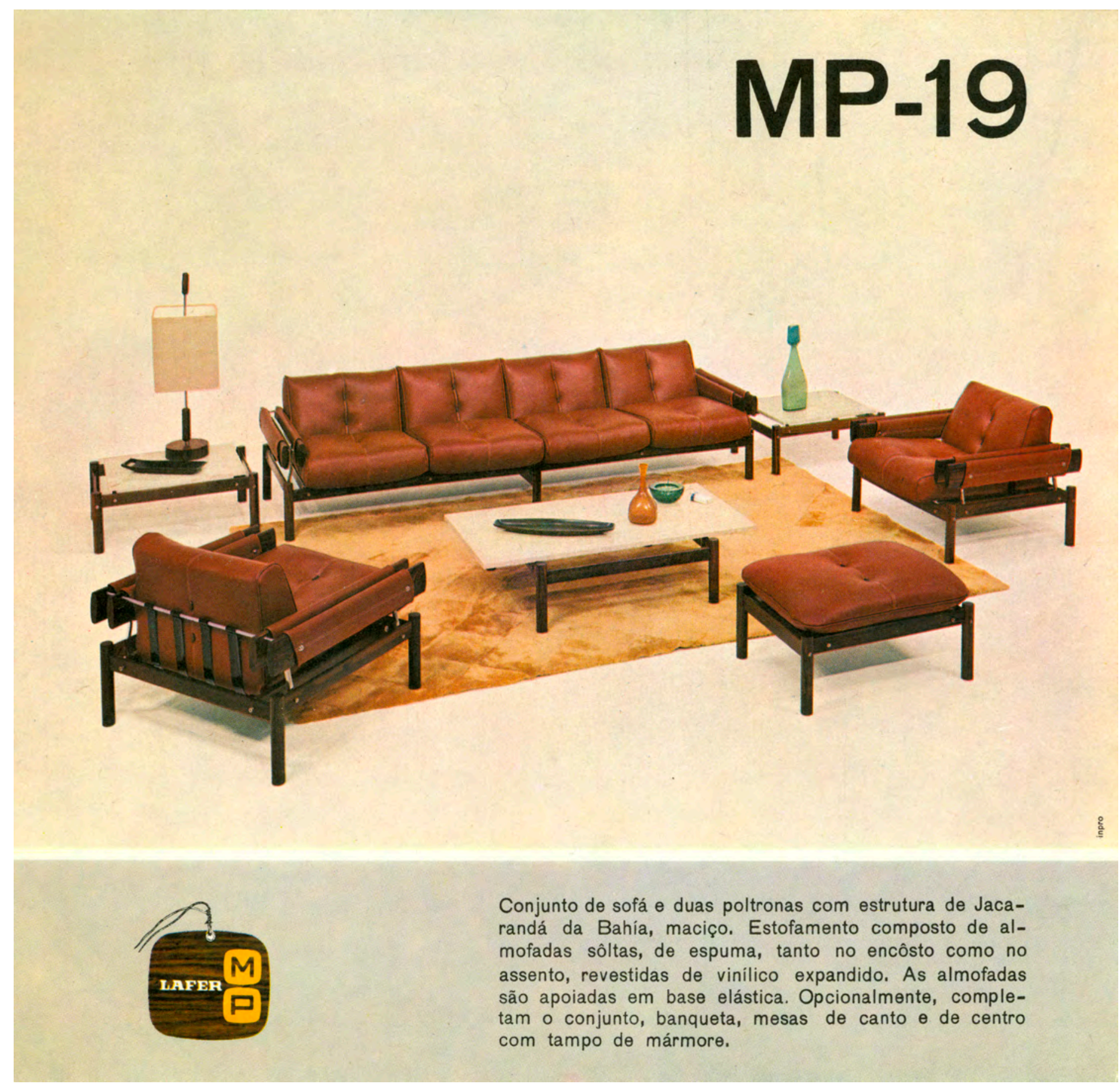

Panfleto de venda e apresentação do conjunto

MP 19. Esse material era usado pelos

representantes e equipe de venda.

Fonte: arquivo do designer 


\section{MP25}

O MP25 é uma variação popular que mistura elementos do MP13 e do MP19. A concepção estrutural é a do MP13, com os braços do MP19. O estofamento único, base do MP1, foi retomado de forma única, já que sofás com estofamento parcelado não eram bem recebidos pelas classes de poder aquisitivo médio. O assento já estava sendo fabricado com espuma injetada, frente produtiva que foi desenvolvida por Percival, juntamente com a produção da fibra de vidro, tecnologias que foram indispensáveis para o crescimento da indústria e produção das peças futuras. Fechamos assim o subcapítulo destinado às primeiras experiências, já não tão primeiras assim, tentando obedecer uma lógica de raciocínio projetual e de produção. Passemos aos desenhos emblemáticos dos móveis de luxo.

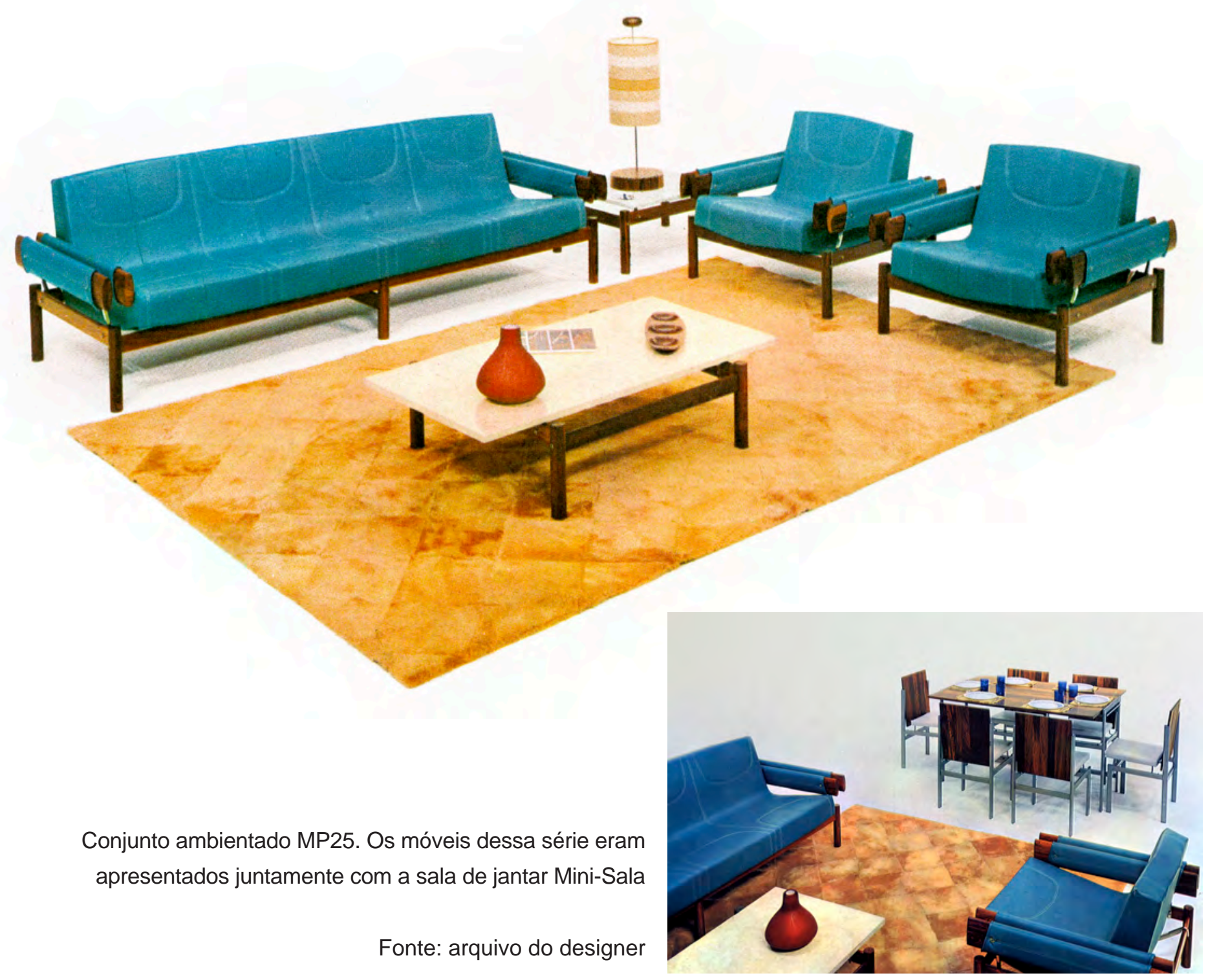


Conjunto

ambientado MP29

Fonte: arquivo

do designer
MP29

Esse conjunto peculiar, embora fuja das linhas formais e produtivas das primeiras experiências, aponta para um pensamento que virá a ser colocado em prática mais tarde, a partir do MP61, nos produtos de luxo. O conjunto era destinado para o consumo da classe média, e consolidou uma nova experiência formal dentre as demais outras séries que se seguiram.

Sublinha-se a solução do corpo em concha capitonada, apoiado sobre estrutura independente. $\mathrm{O}$ mesmo partido formal foi usado para a linha MP81, que recebeu concha em espuma injetada, enquanto a estrutura de travamento em " $x$ " foi incorporada ao corpo do assento do móvel. A estrutura é desenhada em angulo, posicionando os pés na diagonal em " $x$ ". Isso foi usado em outras linhas de alguns sofás camas.

O conjunto é composto por sofá de três lugares, poltrona, banqueta e mesas de centro, a partir da mesma concepção estrutural. O travamento é realizado com encaixes das travas em sanduíche, com juntas metálicas. As medidas dos perfis em madeira são constantes e variam apenas para as horizontais de travamento dos perfis baixos do sofá e da mesa de centro.

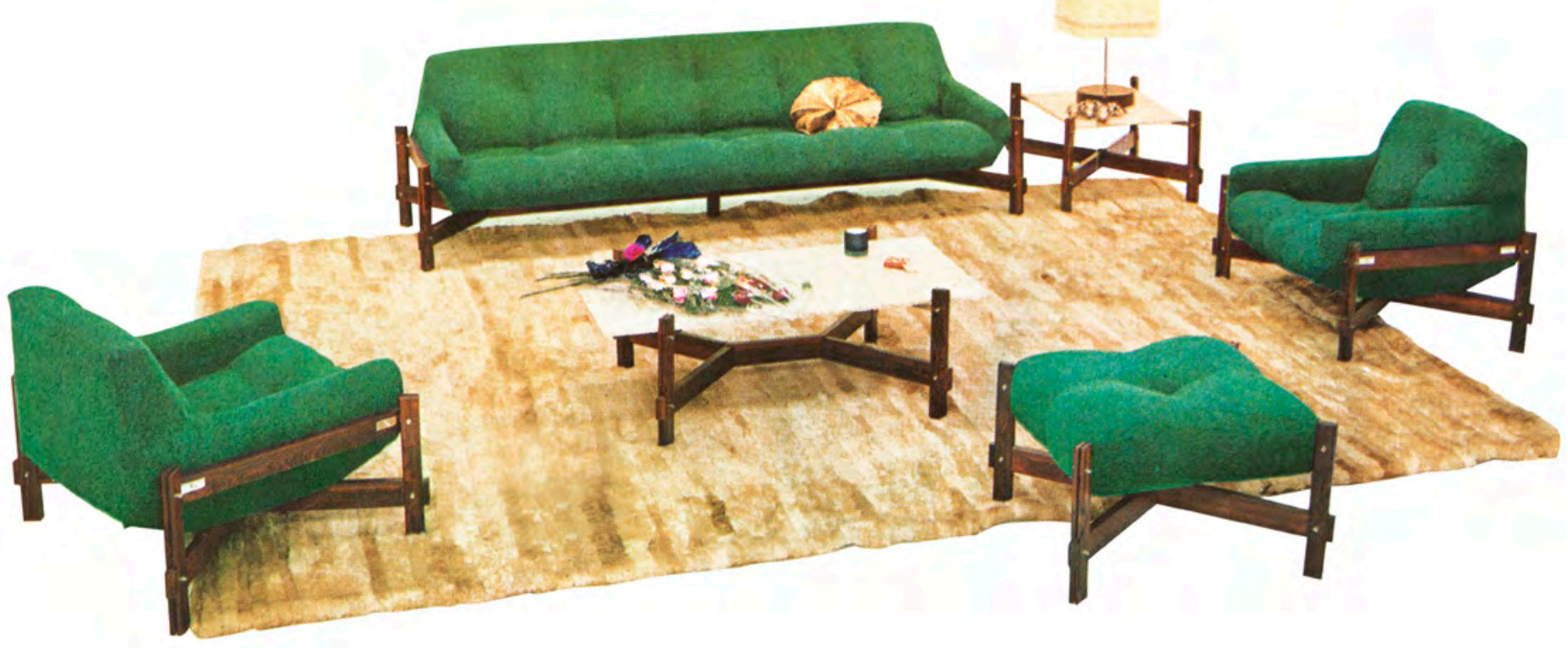




\section{MP49}

Embora o conjunto não pertença necessariamente ao período das primeiras experiências, ele se encontra em uma fase de transição da carreira do designer. $O$ desenho ainda segue um padrão encontrado nas linhas anteriores, mas propõe novas soluções formais que irão apontar para a produção da MP51. Podemos considerar o conjunto como uma transição. A partir desse modelo os componentes serão soltos. Estrutura e estofado não estarão mais solidificados em unidade.

Conjunto

ambientado

MP49

Fonte: arquivo do designer
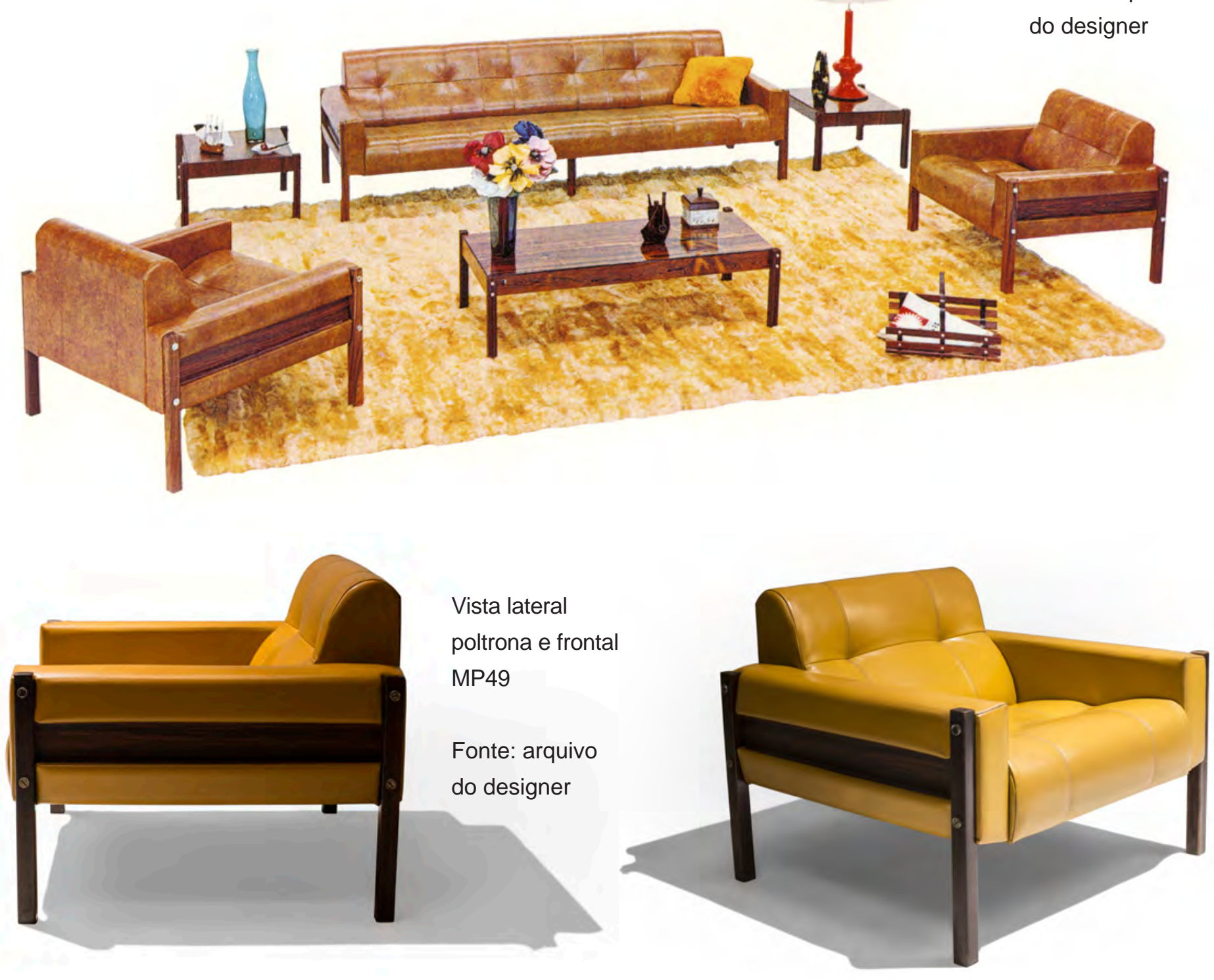
Outras séries foram produzidas dentro dos paramêtros estabelecidos durante os primeiros anos de produção. Os desenhos que seguem são produtos desenvolvidos a partir da mesma lógica referente aos móveis já apresentados, com algumas variações estrutrais e visuais.

Na maioria dos casos, esse produtos foram pensados para a venda no varejo, levando em conta o gosto popular da época. As estruturas passaram para o vertice dos móveis, e muitas vezes apresentaram desenho rebuscado, como é o caso do MP93. Esse modelo, em especial, atende uma exigência do gosto neo-colonial, muito difundido nos anos 1970. É interessante notar que sua variação, o conjunto MP95, possui desenhos mais simples, o que barateava os custos de produção. Mais uma vez, a versatilidade da produção seriada, pensada por Lafer, é evidenciada. Os componentes fabricados serviam a uma multiplicidade de produtos e linhas.

\section{MP 53}

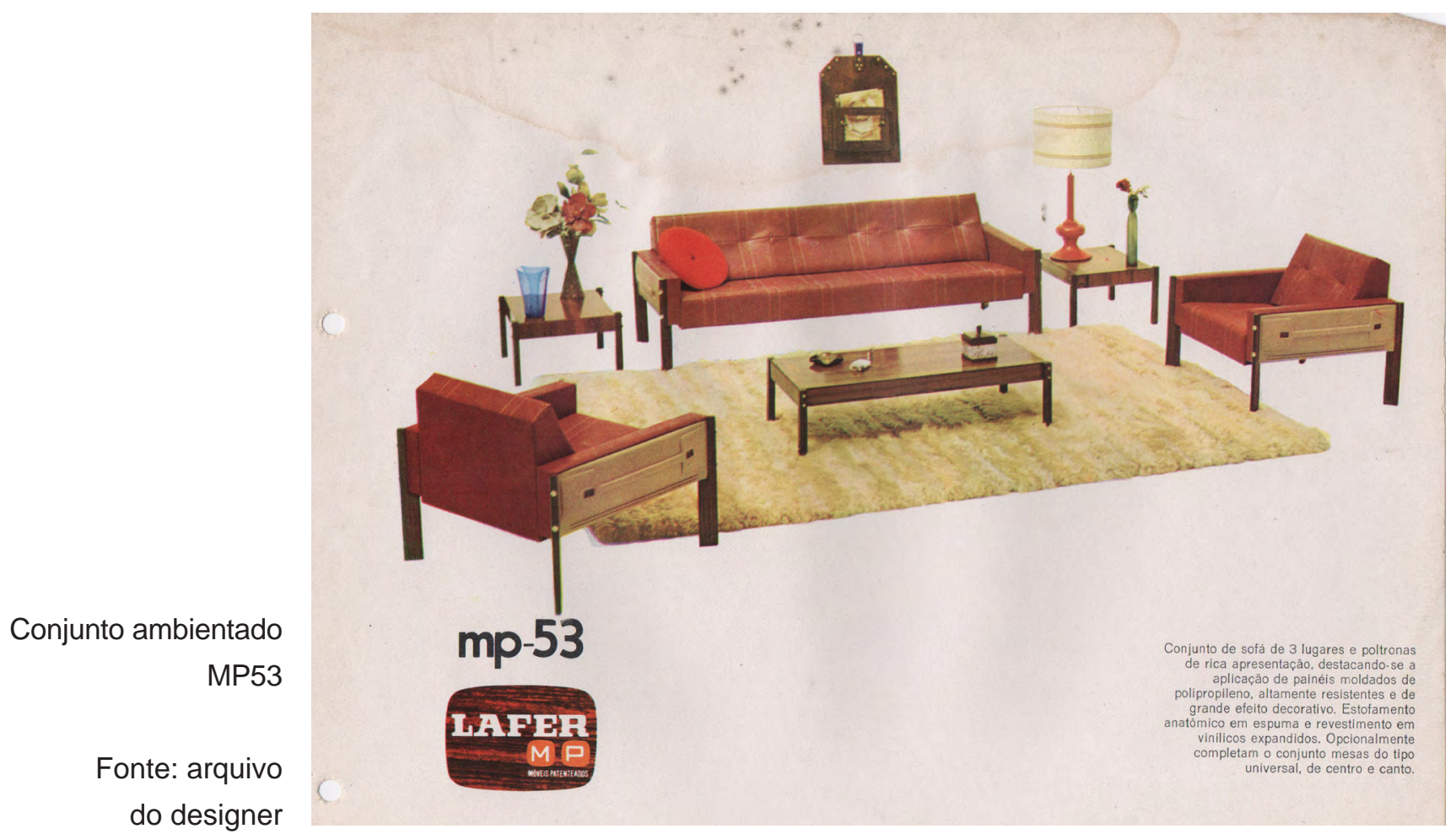




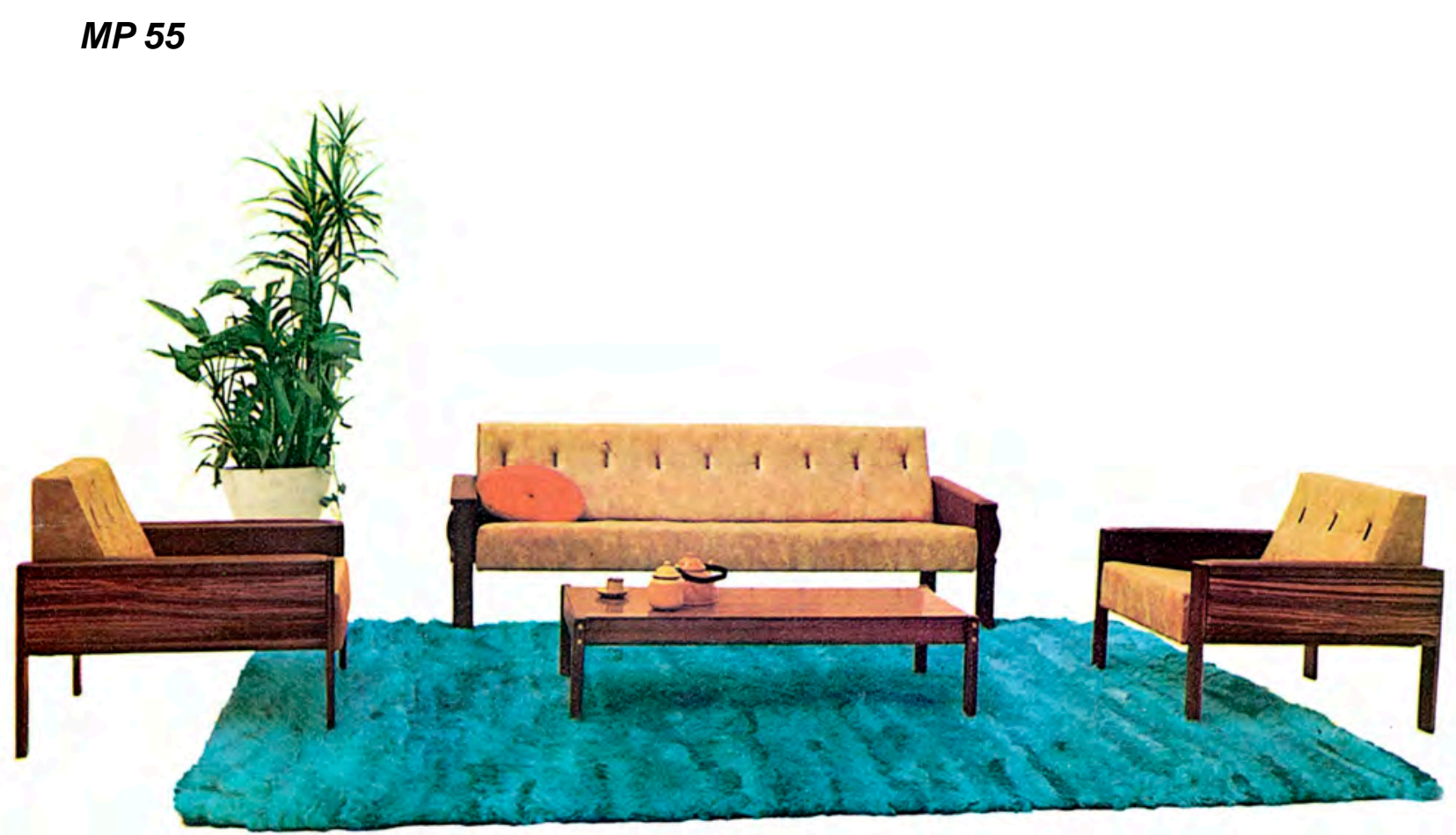

Conjunto ambientado MP55

\section{MP63}

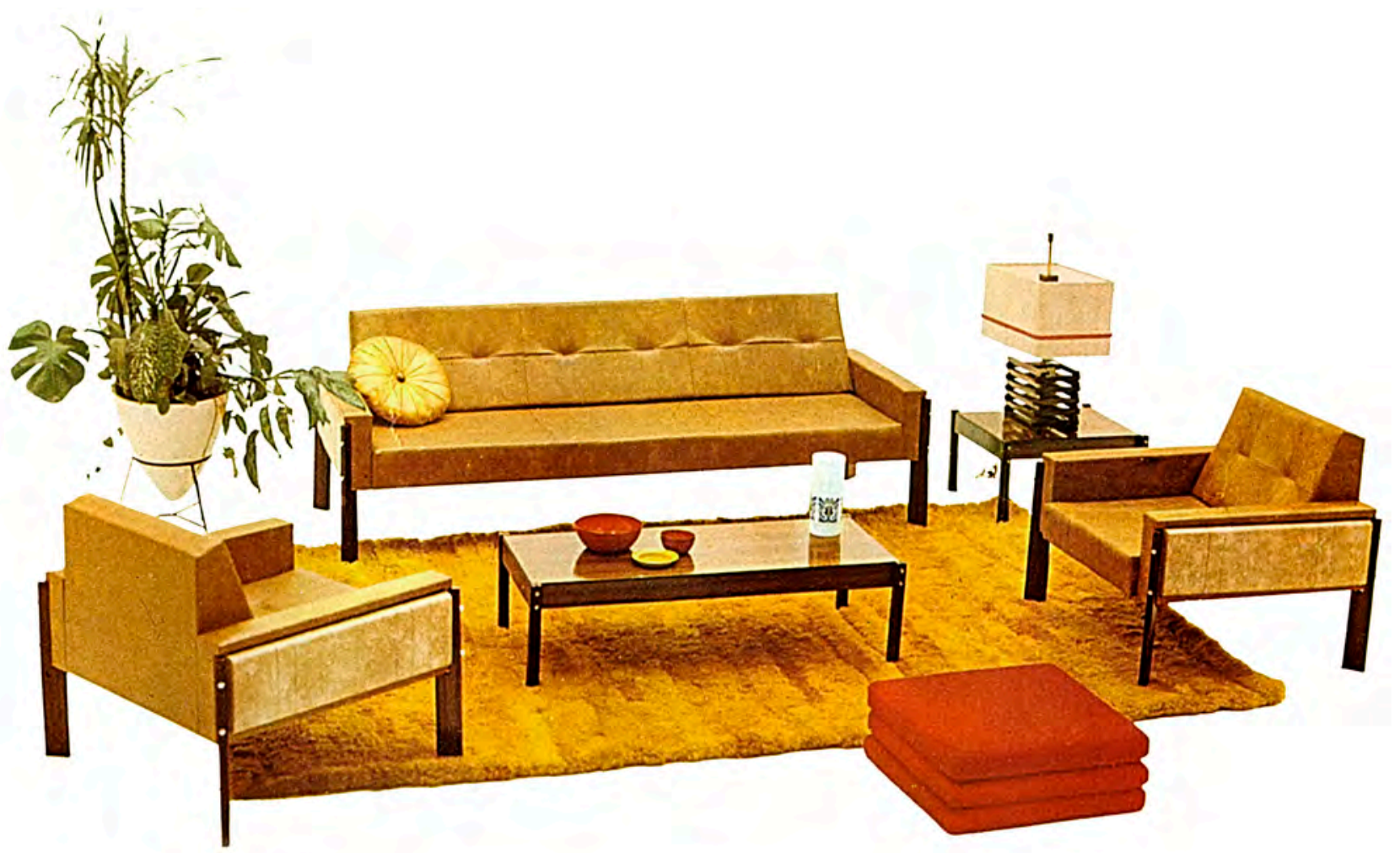

Conjunto ambientado MP63

Fonte: arquivo do designer 
MP93/ 95

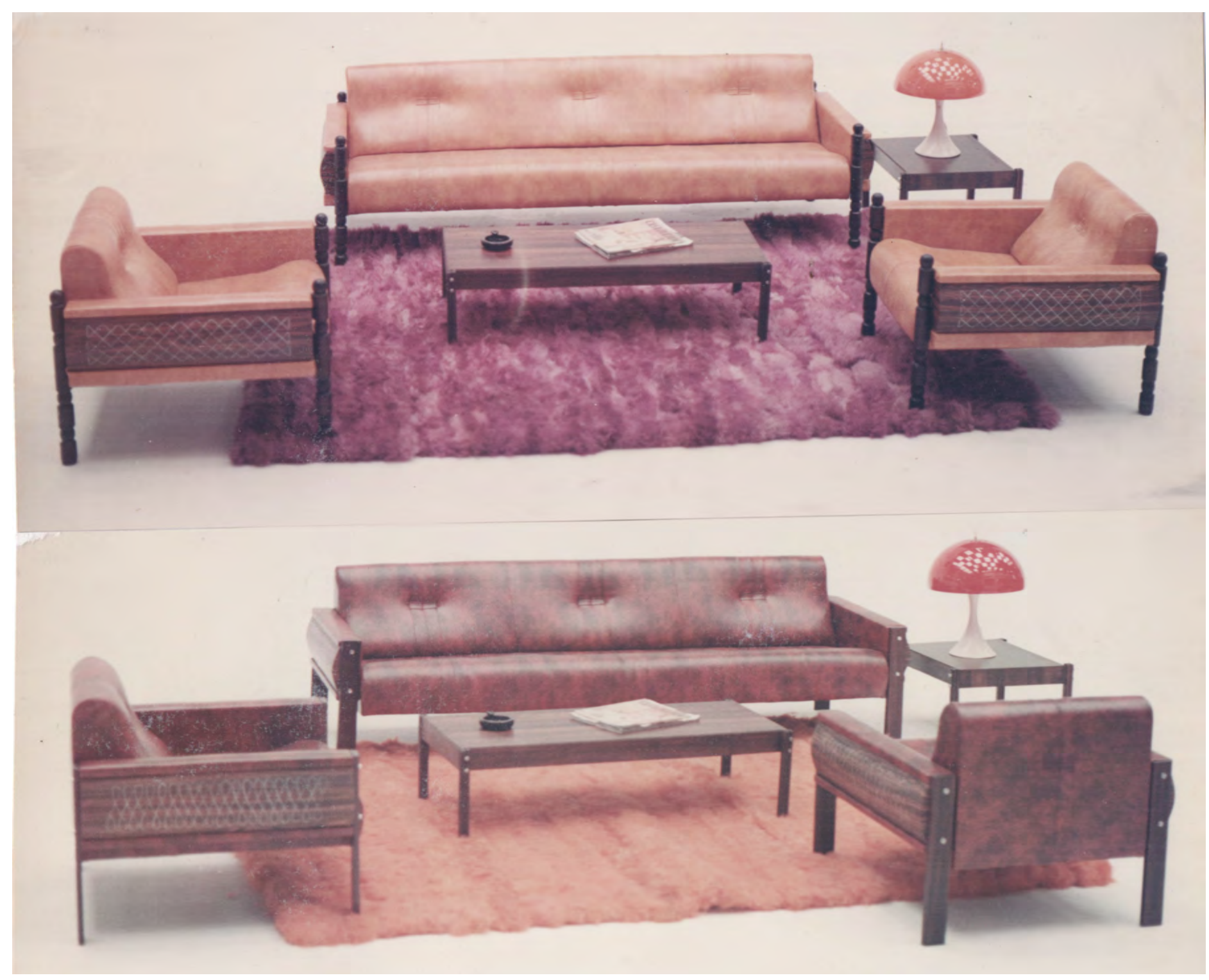

Conjunto ambientado MP63

Fonte: arquivo do designer 


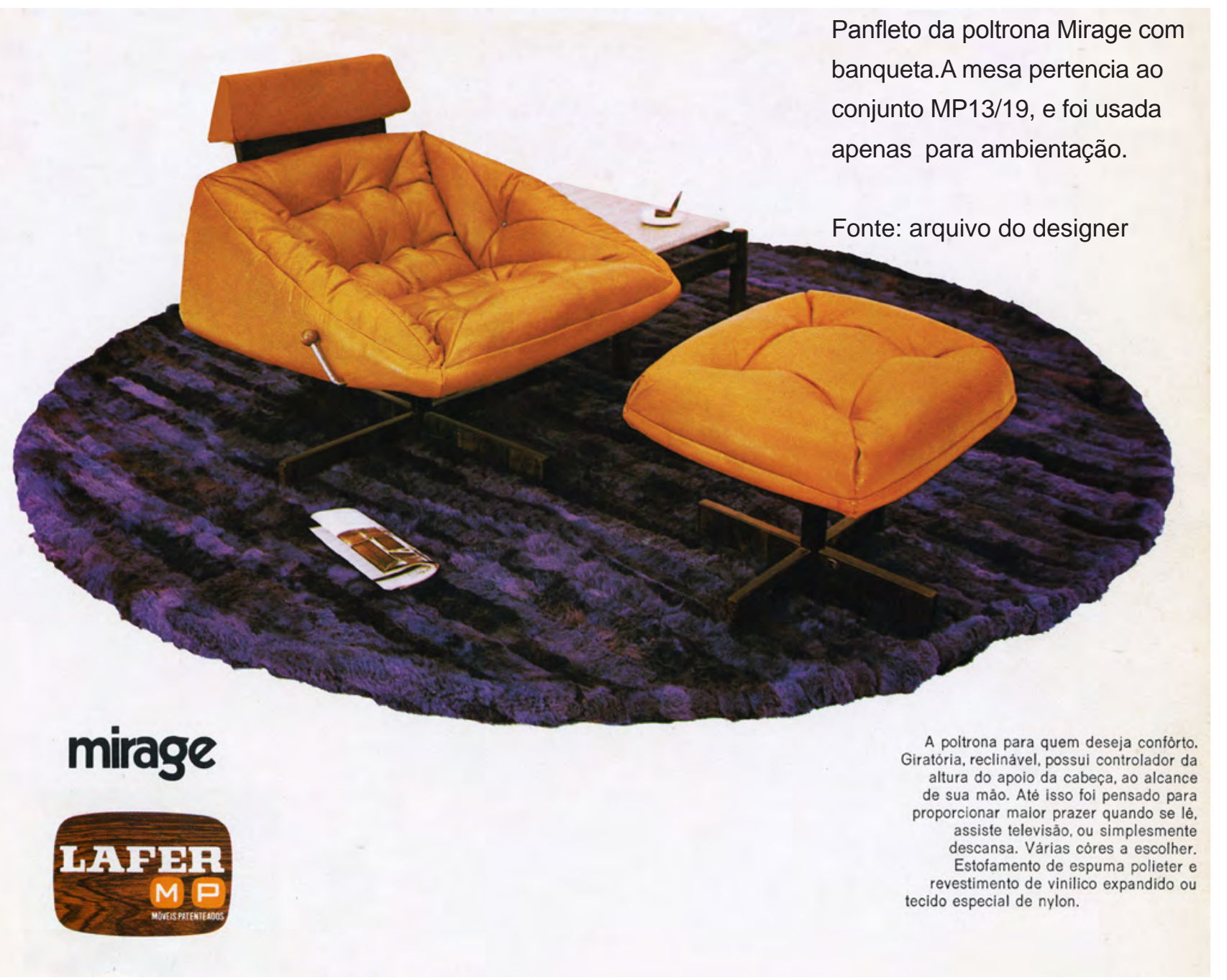

Mini-Sala em

modo fechado

Fonte: arquivo

do designer

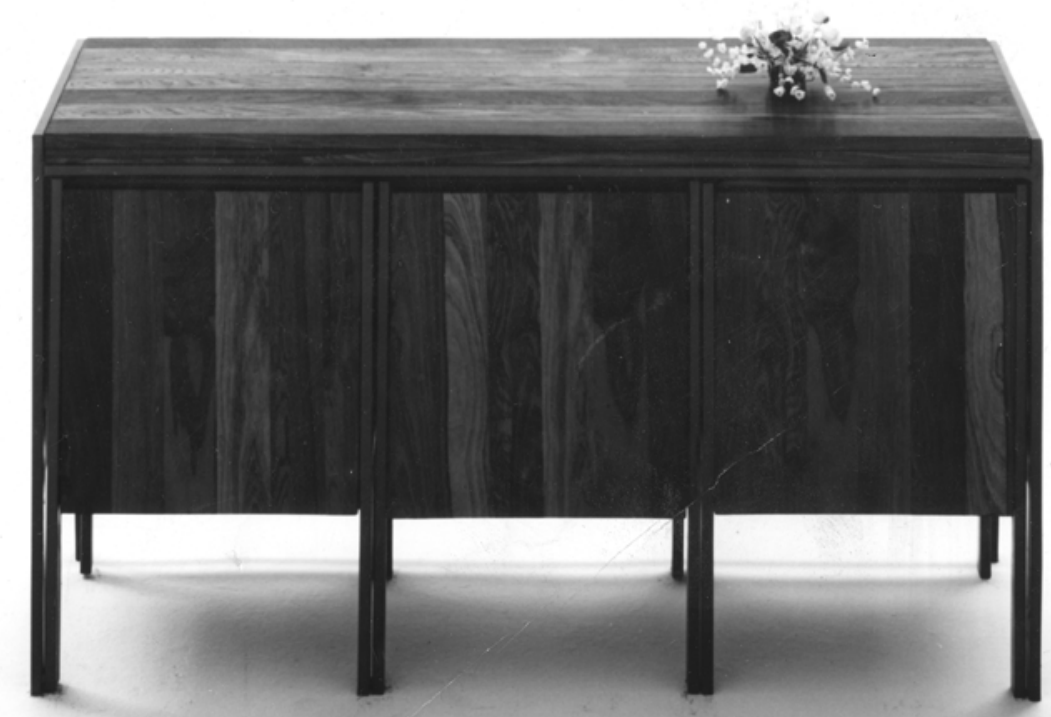


Recorte de jornal sobre o prêmio adquirido pelo desenho da Mini-Sala

Fonte: arquivo do designer

\section{Laureados da UD na \\ Polônia}

Dois prodatos premiaAos no IV Concurso para Domesticas, promovido pela Feira de Vutlldades dos á Feira de Poznan, a na Polonia, Sievemente "Mfinl-Saln", de autoria do arquiteto Perciral Lafor - que receben o pre. do XCrR $3,000,00-$ a lampada fluorescento "Muflex", de autoria de Cúbel Medeiros, produzida pela Industria Carraum eertificado que recebeu Forma". Também a "Mesa extensivel de 6 para 8 pessoas". de autoria de nio Bioni, produzida por Bloní sCin, Ltida recebeu ceruficeado de "Boa Forma". Os premios fo. ram entregues ontem, na mesticas

A Mirage, como outras poltronas avulsas, podem ser consideradas parênteses na trajetória de Lafer, considerando a consolidação das séries de reclináveis produzidas até hoje. A MP43 foi desenvolvida a partir da ideia de reaproveitamento de um produto de insucesso de venda, a Mini-sala.

Desenhado em 1966, o conjunto de jantar multi-uso denominado "Mini-sala" foi uma tentativa de produzir móveis para espaços reduzidos. É composto por uma mesa extensível e seis cadeiras que, quando recolhidas, formam um volume sólido, podendo ser usado como aparador. O projeto rendeu a Percival o Prêmio Roberto Simonsen, durante a VIII Feira de Utilidades Domésticas de São Paulo. No entanto, com o insucesso das vendas, sua produção foi interrompida no mesmo ano.

Do excedente da produção, Percival criou a Mirage, uma poltrona em estrutura metálica revestida em madeira e tecido, com um sistema sobedesce de apoio de cabeça ativado por uma alavanca. Os pés e estrutura do apoio sacral foram confeccionados das placas de madeira revestidas em jacarandá usadas nos tampos, assentos e encostos da "Minisala".

O produto foi exportado. A publicidade foi realizada com Jô Soares, o que lhe rendeu grande retorno de público. Fazia par com a poltrona, uma banqueta em mesmo estilo.

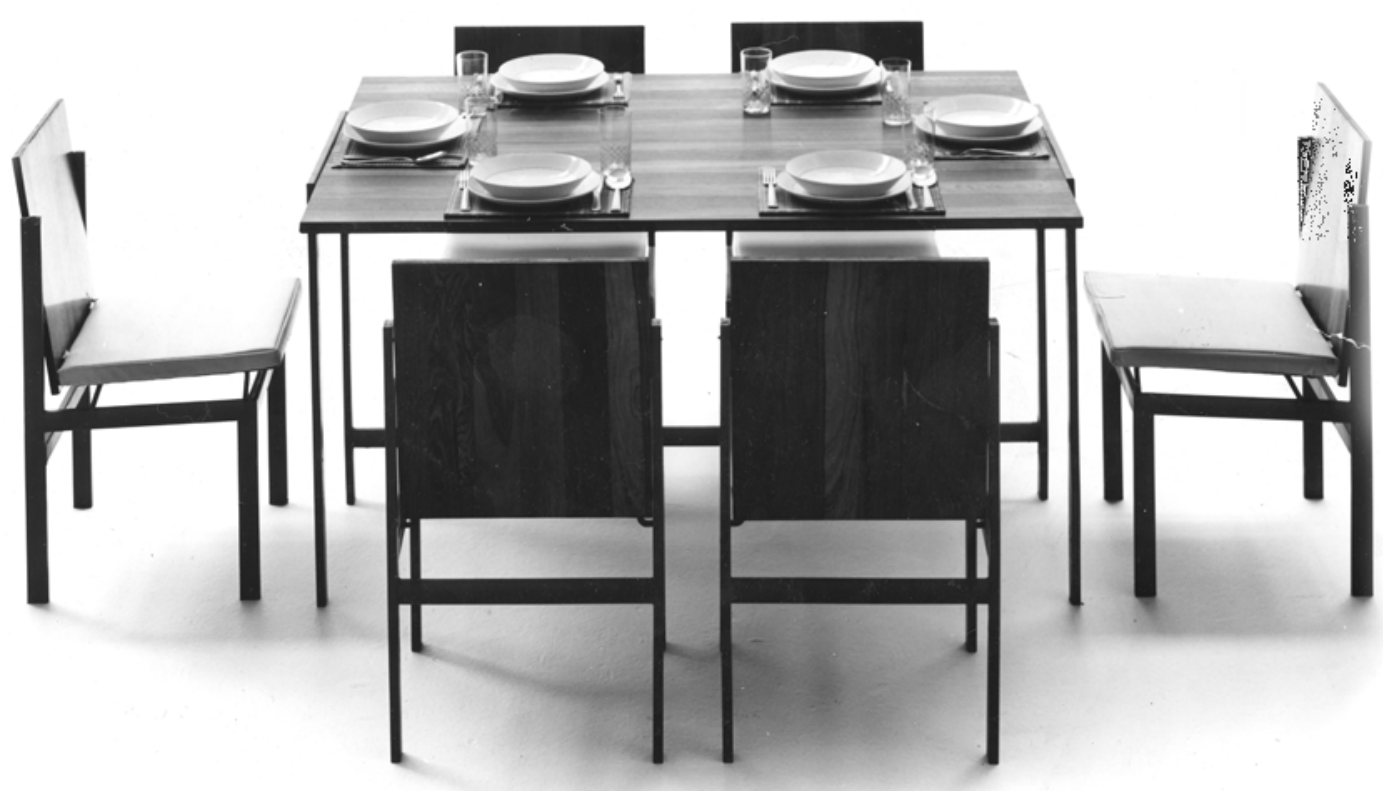

Mini-Sala em modo aberto.

Fonte: arquivo do designer 


\section{O SOFÁ - CAMA}

O sofá cama, enquanto tipologia do mobiliário, nasceu e perpetuou-se pelo cotidiano estabelecido pela vida "moderna". A lógica racionalista que no período entre guerras ganha responsabilidade de reconstrução urgente, chega ao Brasil como resposta à necessidade de construção rápida do ambiente doméstico destinado à nova população urbana crescente, em especial a classe média. O aumento da vida urbana nos anos 1950 foi considerável. Enquanto que na década de 40 apenas 31\% da população brasileira estava nas cidades, a partir de 1950 o processo de urbanização intensificou-se. O plano de industrialização promovido pelos governos de Getúlio Vargas e Juscelino Kubitschek favoreceu a formação de um mercado interno integrado que aumentou vertiginosamente a população das cidades, principalmente no sudeste do país. Nos anos 1970, mais da metade dos brasileiros habitava áreas urbanas, onde a oferta de emprego e de serviços eram maiores. ${ }^{27}$

Desde os anos 50, produtores pensavam e forneciam móveis que se adequassem às múltiplas necessidades dos consumidores, dentro de um programa arquitetônico racional de dimensões reduzidas. Designers das décadas de 50 haviam introduzido a modalidade do móvel reversível. Mesas tipo ninho, poltronas reclináveis e outras peças com múltipla função se tornaram comuns nos lares da classe média. Os móveis de Scapinelli foram um exemplo disso. O sofá cama já era uma forma antiga explorada, no entanto, de difícil manuseio, muitas vezes pesado e desajeitado. Em sua maioria, era constituído de uma estrutura de madeira com rodas e possuía um sistema de fechamento manual tipo "click-clack". Quando não, apresentava apenas um sistema de cama corrediço, sobre o qual se desdobrava a espuma do encosto, se aproveitando de uma ideia de modernidade e seus modismos (não há como dissociar cultura industrial de massa e pensamento de moda), em que a automação ganhava cada vez mais espaço na vida das massas. ${ }^{28}$

27 Instituto Brasileiro de Geografia Estatística - IBGE - <https://ww2.ibge.gov.br/ home/estatistica/populacao/censo2000/tendencias_demograficas/comentarios.pdf>. Acesso em 15/12/2-17

28 Estamos falando da criação da sociedade de consumo brasileira, do acesso aos bens de consumo de forma massiva, da indústria cultural, tão bem identificada por Adorno e Baudrillard. No Brasil, as políticas adotadas pelos governos anteriores 
Percival Lafer dedicou-se a pesquisa do sofá-cama enquanto tipologia. O investimento em projeto e tecnologia culminou na grande quantidade de estruturas articuladas criadas e patenteadas pelo designer. Os princípios formadores da base produtiva das poltronas articuláveis e outros móveis multifunção, produzidos e comercializados até hoje pela Lafer, remetem às primeiras experiências dos sofás-camas. Essa tipologia pontua toda a trajetória do designer dentro da concepção do móvel utilitário.

ao golpe de 64, principalmente a política econômica nacional-desenvolvimentista instaurada pela gestão de Juscelino Kubitschek, estimularam a grande difusão de bens de consumo duráveis, atrelados, pela publicidade massiva, às ideias de modernidade, avanço e progresso. O estilo de vida norte-americano capitalista chegava ao Brasil sem indistinção, nem reservas. Assim o ideário de progresso inculcado na população iria ser traduzido na produção industrial e na publicidade. Faz parte deste movimento, a introdução da TV, eletrodomésticos e a grande inserção do automóvel no cotidiano da população. (N.d.A.)

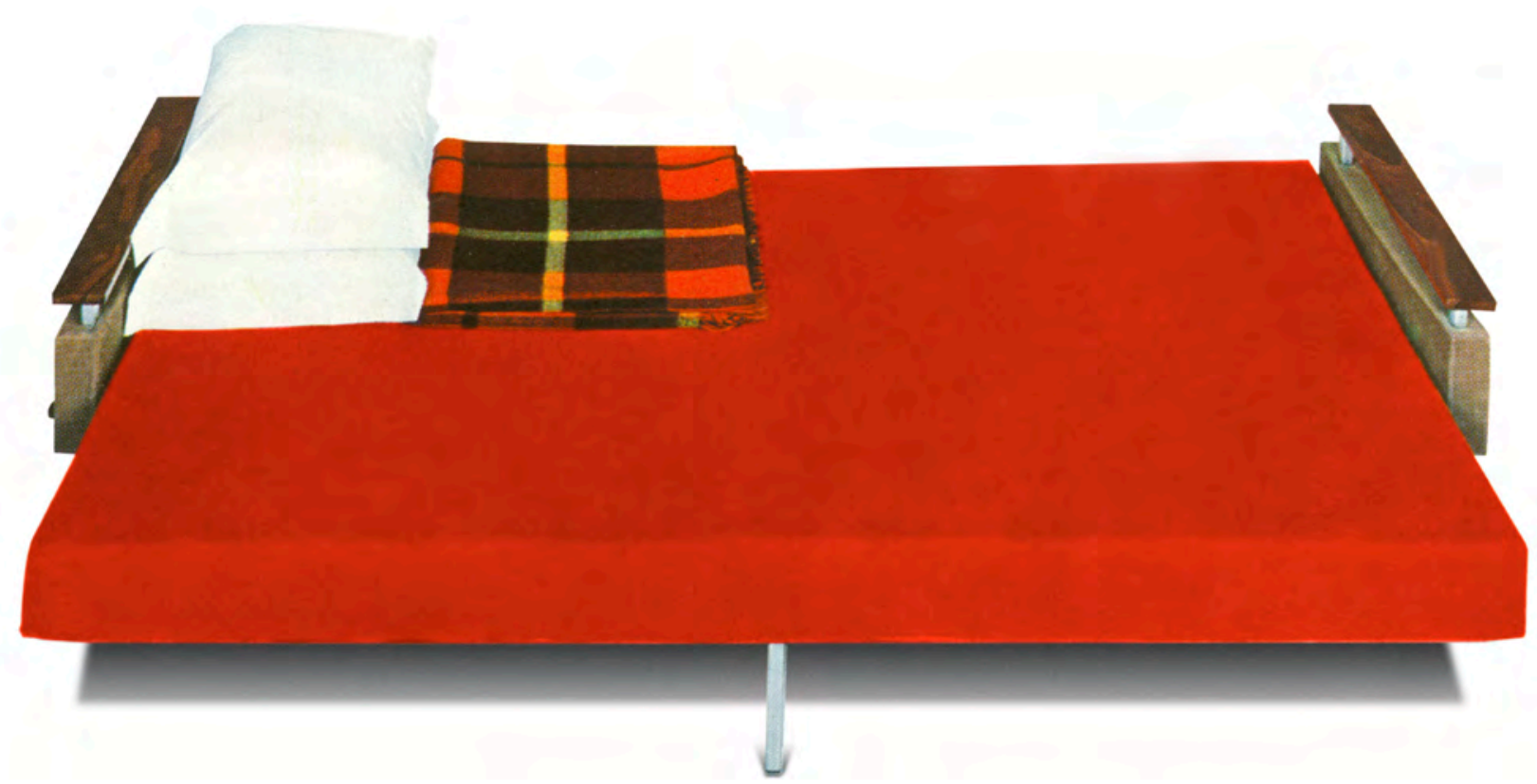

O primeiro sofá-cama, o MP7, em seu modo aberto.

Fonte: arquivo do designer 
Conjunto de poltronas e sofá cama, MP7, com acabamento em courino, sobre o qual aplicava-se a solda eletrônica para criação dos gomos.

Fonte: arquivo do designer

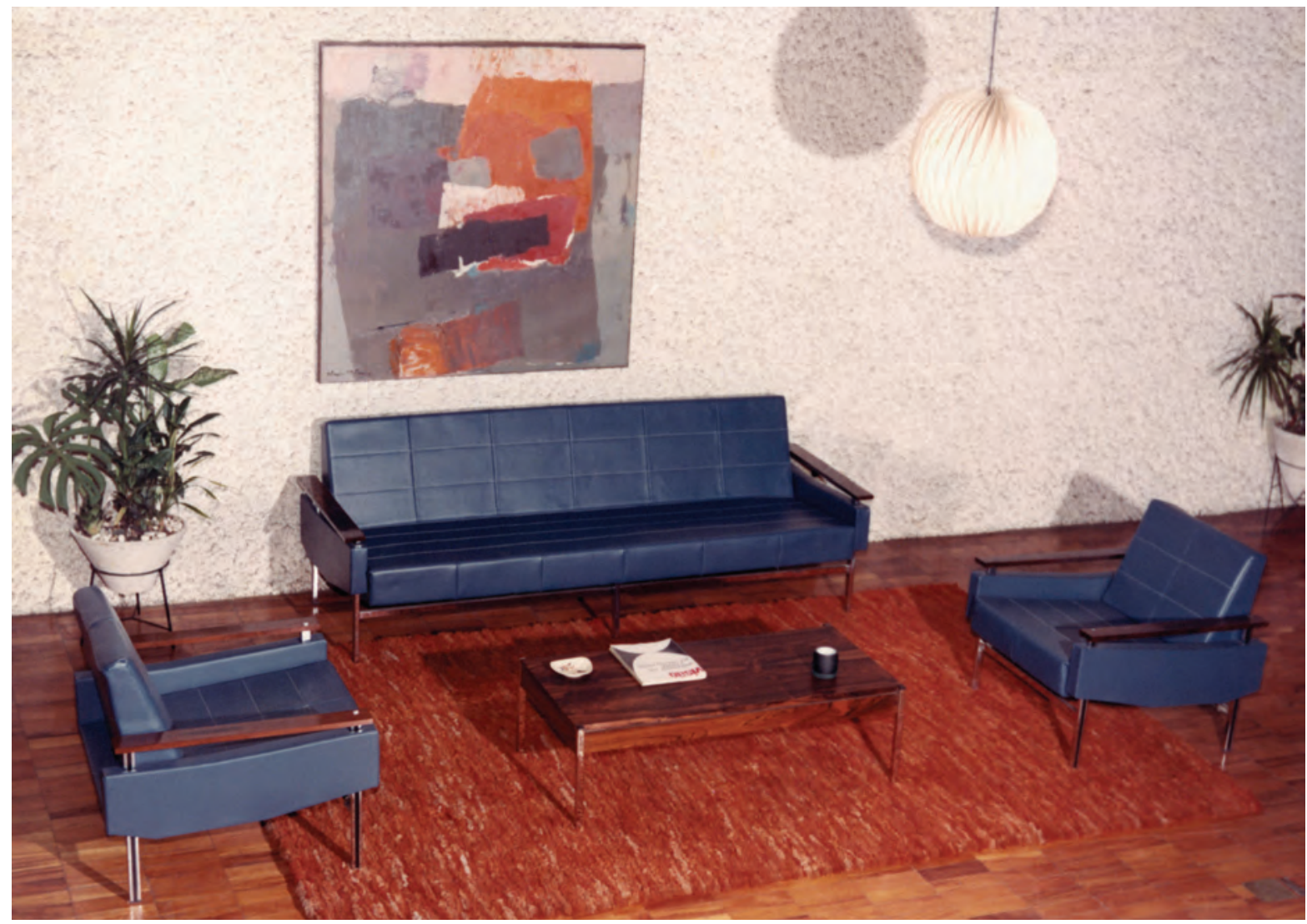

Conjunto de poltronas e sofá cama, MP7, com acabamento em tecido. Uma técnica especial de colagem, , por meio de bastidor, foi desenvolvida para o revestimento com padronagens.

Fonte: arquivo do designer

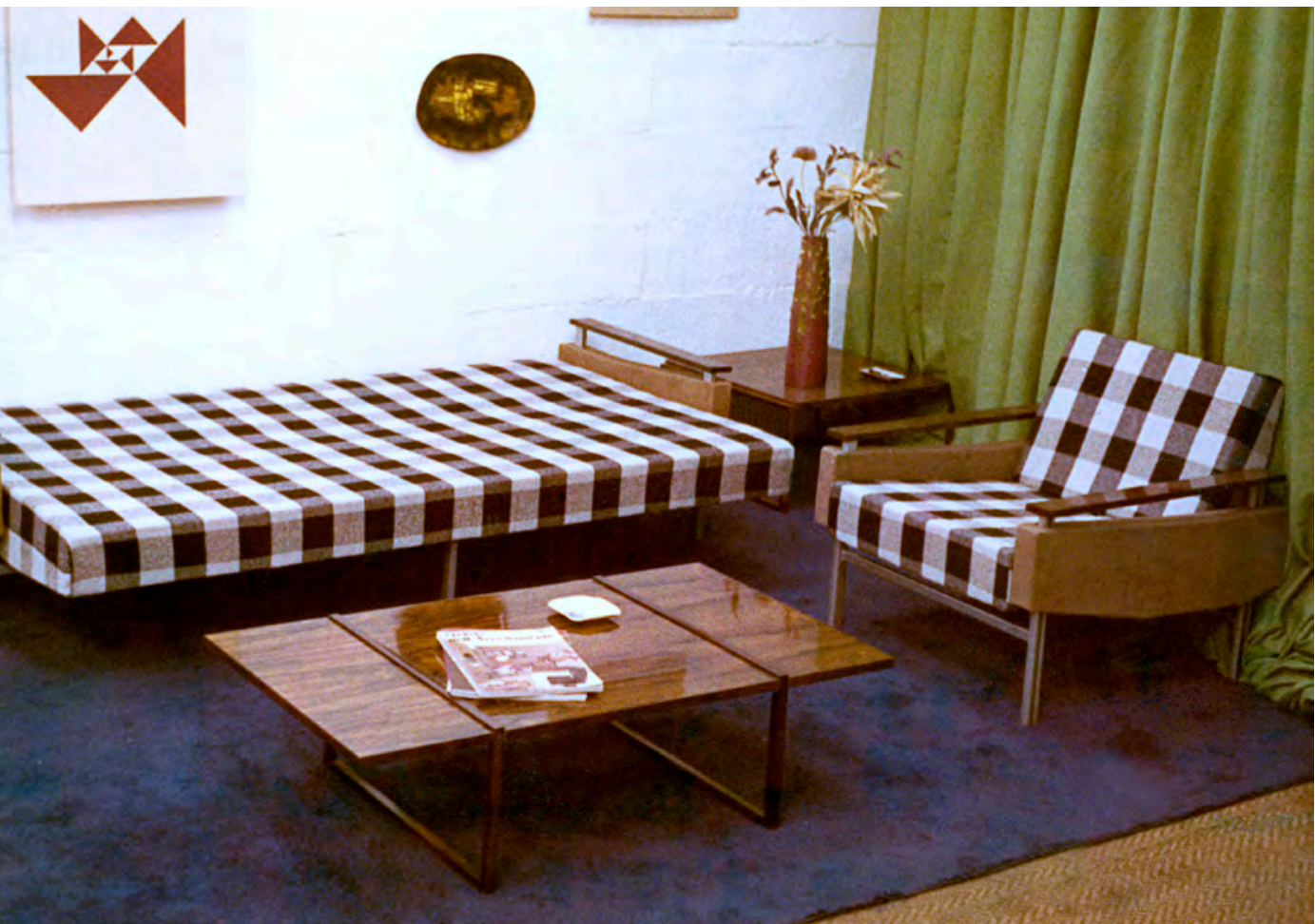




\section{MP7 - 1965 (quatro anos antes do homem pisar na lua)}

O MP7 foi um produto divisor de águas no trajeto criativo de Percival Lafer. Embora esteja compreendido nos anos em que realizava suas primeiras experiências, o conjunto de móveis foi importantíssimo para a solidificação dos negócios e para a inauguração de uma nova linha de pesquisa em estruturas articuláveis e móveis multiuso. Além disso, o MP7 seria o produto representativo para o início das vendas no exterior. Juntamente com o sofá-cama, foram criadas as versões poltrona.

Percebendo as novas dinâmicas de consumo, agora mais do que nunca pautadas por modismos e pela promessa industrial continuada pelo governo ditatorial, Percival cria o MP7. O designer, como já dito, estava preparando-se para a exportação, e necessitava de um produto que encontrasse respaldo inclusive no mercado internacional. O lançamento do MP7 coincide com o ano de sua participação em uma feira de móveis e utilidades domésticas realizada na Suécia, da qual Percival participou, patrocinado pelo Governo brasileiro.

\section{Detalhe do panfleto \\ publicitário \\ utilizado para \\ explicar o \\ acionamento \\ automático \\ do pedal}

Fonte: arquivo

do designer

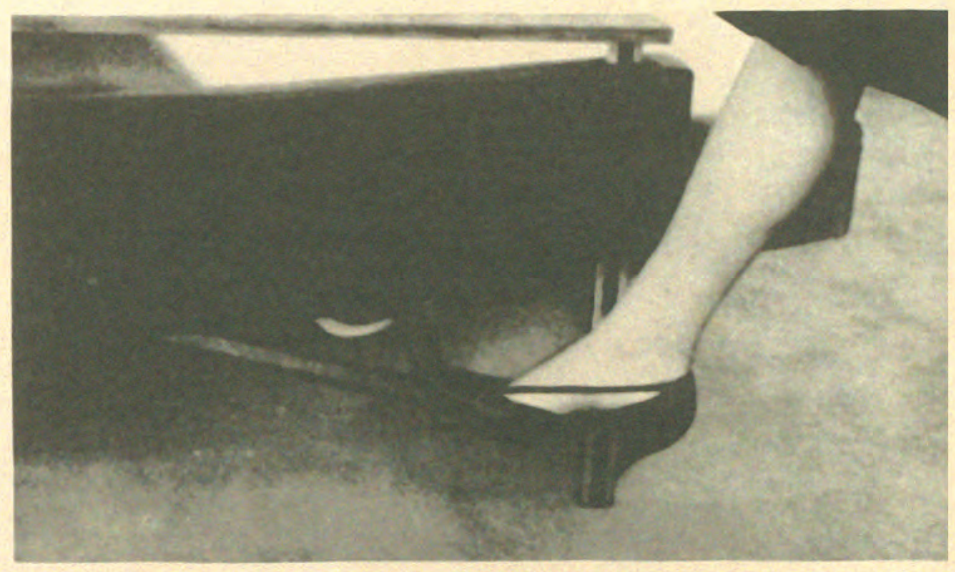

E para abrir e fechar? Também é diferente. Basta pisar num pedal oculto e o Sofá.Cama Lafer.MP abre-se e fecha-se sozinho.

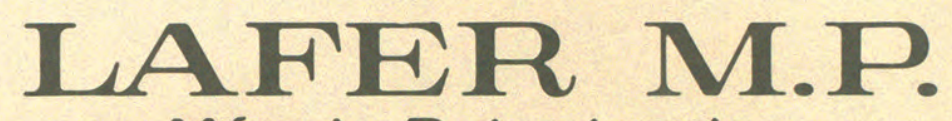

Móveis Patenteados

qualidade da Plastispuma

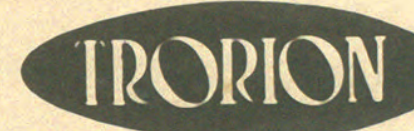


O sofá cama é composto por uma estrutura articulada em aço, o que o deixa mais leve, físico e aparentemente. O estofamento era uma novidade. Constituído de Plastispuma, material tecnológico produzido pela indústria Trorion e usado para fabricação de estofamento automobilístico, possibilita a produção do móvel em grande escala, dispensando o uso complicado de molas e outros sistemas. A estrutura foi solta dos braços ganhando autonomia para que realizasse o movimento de abrir e fechar, mas desta vez de forma quase que automática. Percival criou um sistema de articulação, com encaixes e molas que, ativadas por pedal, abrem e fecham o sofá mecanicamente, sem nenhum esforço. Basta pisar no pedal que a coisa se coloca em marcha, como num automóvel.

A solução articulada, adotada nesse móvel foi inaugural no pensamento de projeto de Lafer. A partir de então, as estruturas articuladas, foram uma constante, resultando nas poltronas reclináveis, que são hoje o carro chefe da Interdomus Lafer. O sistema de acionamento de alavanca fica dentro do braço e é ligado a um pedal, que, ao ser pisado, faz girar uma peça metálica denominada "excêntrico". O giro impulsiona um pino que desliza em um trilho, provocando o movimento do acento para a frente, que, por sua vez, traz o encosto atrelado à estrutura. As percintas elástica do estofado, presentes nos conjuntos anteriores, são utilizadas em dois jogos de tiras cruzadas - um para sustentação do assento, e o outro para o encosto, quando deitado. $O$ jogo de percintas trabalham alongando-se ou contraindo-se conforme abertura e fechamento do sofá.

Além do mecanismo, a extrapolação da divisão dos componentes do móvel, que anteriormente se resumiam em estrutura e estofado, dão um salto no pensamento da seriação e da cadeia produtiva. A estrutura se resume, portanto, a perfis simples de metal, enquanto o braço constituí um novo componente, simples, parte revestido em material vinílico, parte em madeira. Esse desmembramento do desenho, seria notado a partir de então, na maior parte dos móveis. Todos são desmontáveis e contém uma infinidade de mistura material, bem organizada.

O MP7 ganharia, mais tarde, uma versão popular, o MP15. Sua solução formal de independência estrutural dos elementos deu origem a uma série de outras linhas de móveis média gama.

Panfleto

publicitário

do MP7

Fonte: arquivo do designer 


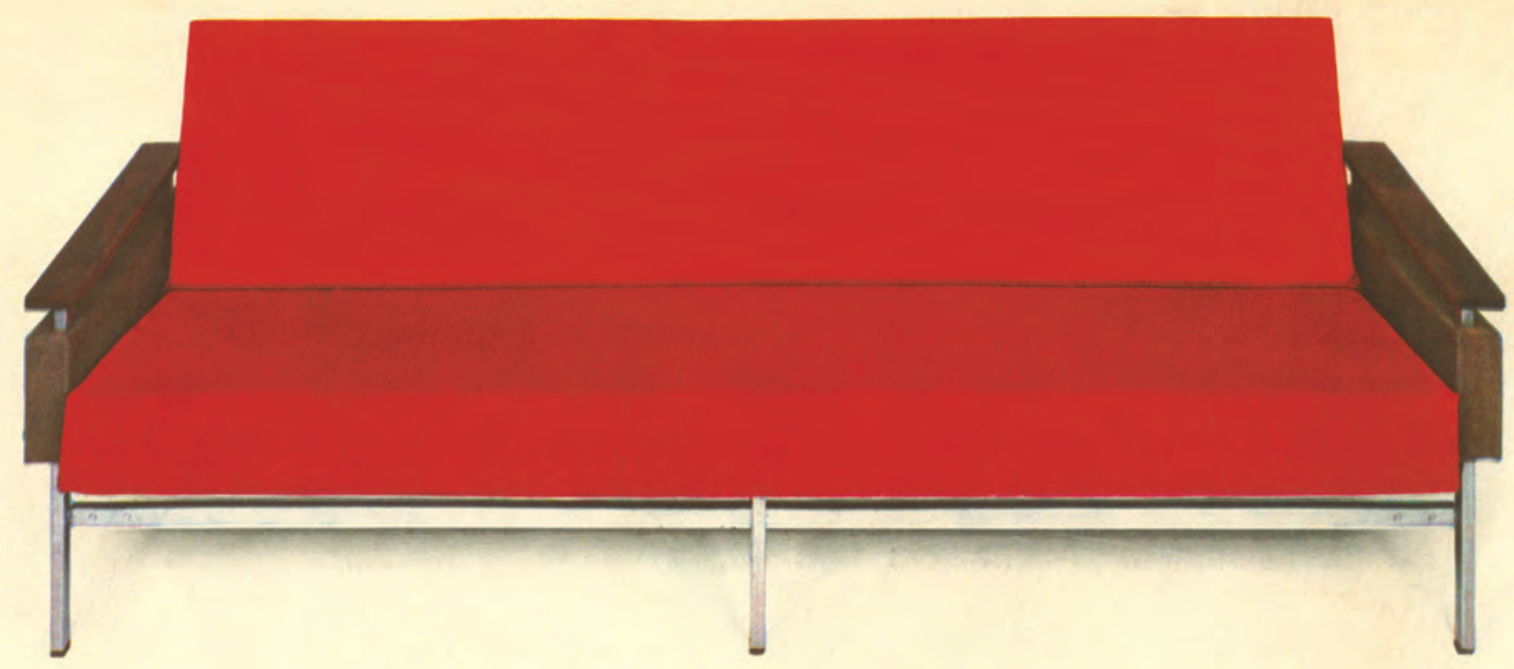

Não parece um sofá-cama, parece?

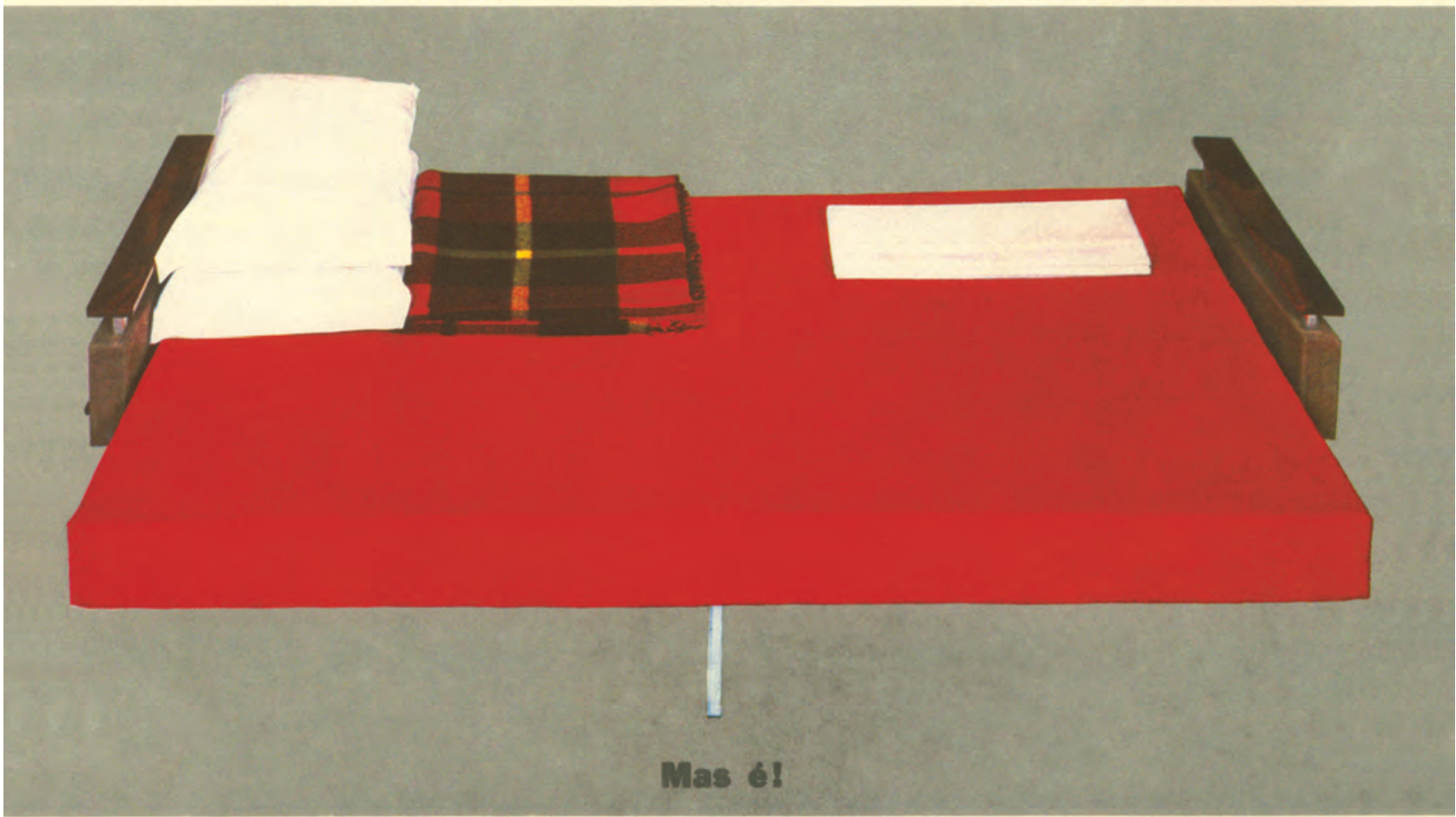

Nosso objetivo principal foi criar um sofá de bom gôsto... que tivesse a vantagem extra de se transformar em cama.

O Sofá-Cama Lafer-MP, quando fechado, nunca revela sua condição de sofácama. (Os outros nåo conseguem ao menos disfarçá-la). Sendo o único que não è feio, é também o único que $V$. teria coragem de incluir numa decoracão moderna. Seu perfil é um dos mais belos desenhos em móveis estofados. A partir de hoje todos os outros sofás-camas parecerão antiquados.

Quando está aberto não parece um sofá-cama: parece, sim, uma cama. Não possui aquela dobra central que torna tão incômodos os demais sofás-camas. V. nunca mais acordará no meio, na parte dura dos sofás-camas comuns. Graças à nova articulaçăo patenteada - exclusiva de Lafer-MP, o assento e o encôsto se encaixam, se justapõem perfeitamente, deixando uma superficie plana, sem ondulaçōes, nem durezas, para the proporcionar conforto total, centimetro por centimetro.

O Sofá-Cama Lafer-MP não tem molas de aço. Preferimos fazer o seu estofamento em Plastispuma Trorion - que recebe o seu corpo como se V. flutuasse num colchão de ar.

Bem, realmente $V$. não precisa dizer a ninguém que aquêle sofá tão moderno que está em sua sala é também uma gostosa cama. Deixe que apenas $V$. o saiba.

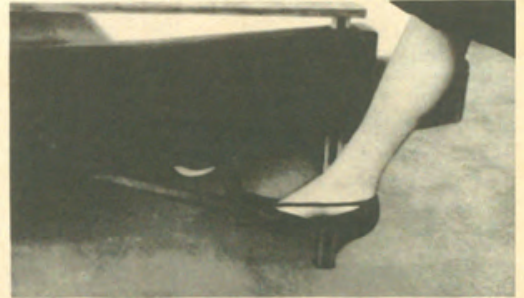

E para abrir e fechar? Também é diferente. Basta pisar num pedal oculto e Sofá-Cama Lafer.MP abre.se e fecha.se sozinho.

\section{LAFER M.P.} Móvels Patenteados 

popular ao conjunto de sofá cama e poltronas do MP7. A estrutura é confeccionada em perfis de madeira maciça, que recebem industrialmente nervuras, onde são encaixadas as travas e os parafusos sextavados. $O$ braço passou a ser constituído de uma única peça de madeira menos nobre revestida de material vinílico. O desenho bojudo foi utilizado em alguns outros braços, obedecendo a ordem máxima da produção em série de maximização do uso dos componentes criados. O estofamento ganhou novo desenho pespontado. Passou-se a usar a Perilan como revestimento, um tecido sintético produzido pela Plastilan Kelsion`s que simulava uma lã fria. O uso de novos materiais tecnológicos foi amplamente divulgado por meio de uma dinâmica de publicidade conjunta com as empresas. Essa parceria fortificava as vendas e aumentava a credibilidade no produto de todas as partes envolvidas.

Os conjuntos MP21, MP31, MP33 e MP37 seguiram o mesmo princípio construtivo do MP15, com algumas alterações de detalhes decorativos nas costuras do estofado e no madeiramento dos braços. Essas duas linhas, mais luxuosas que o MP15, receberam revestimento em courvin e acabamentos em folha de jacarandá. No panfleto desses dois produtos, percebemos a presença do conjunto de mesas laterais e centrais. Essas mesas foram oferecidas juntamente com produtos de linhas mais barata e constaram nas ambientações dos mesmos. Chamadas de mesas universais, sugeriam sua aplicação indistinta e solta de qualquer linha. O modelo resumia-se a um tampo folheado e pés de madeira maciça parafusados nas extremidades .

conjunto de sofá e poltrona MP15

Fonte: arquivo do designer

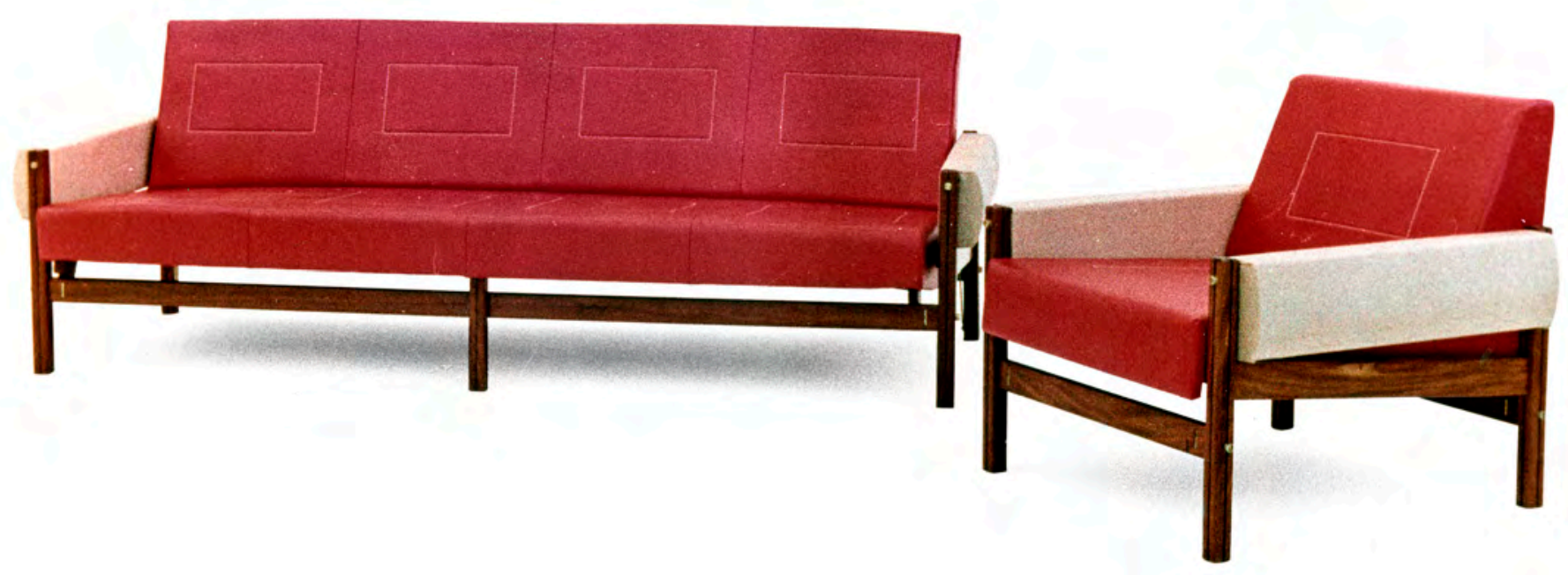




\section{Até hoje um sofá-cama bonito que não parecesse sofá-cama custava caro}

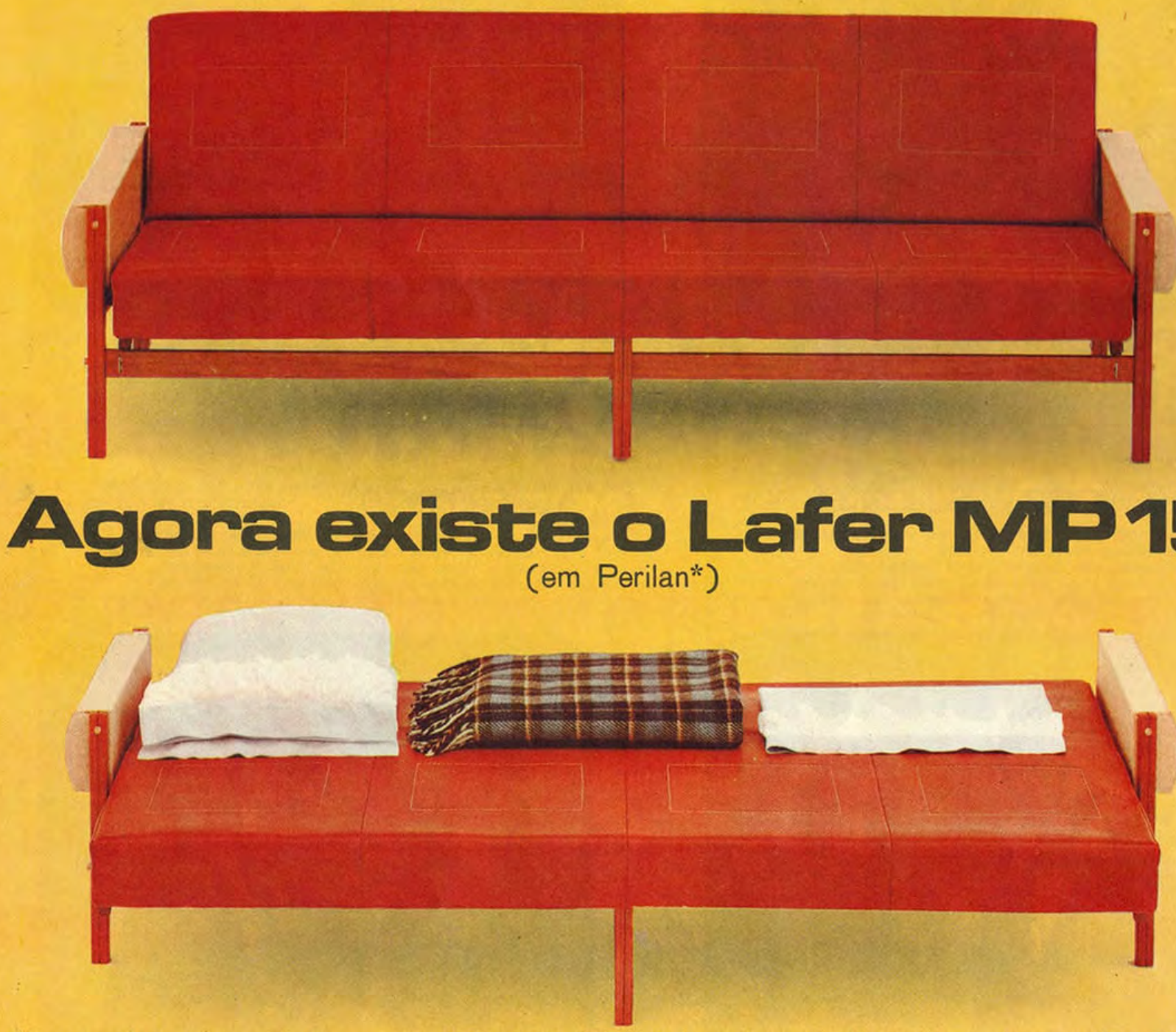

Aberto ou fechado. como sofá ou cama, Lafer M.P. 15 se distingue em tudo dos outros conjugados. O sofá-cama M. P. 15 possui estrutura rigida e desmontável, em madeira de lei; sistema patenteado de funcionamento - silencioso, simplificado, exclusivo, - que dispensa a tradicional dobradiça. E, quando aberto, o Lafer M.P. 15 é uma cama de verdade - sem aquêle incômodo vinco central. Estofado com a Plastispuma Trorion (sinônimo de confôrto)e inteiramen te revestido em Perilan - nôvo e belo material da Plastilan, muito mais durável. No modêlo M. P. 15 está presente a tradicional qualidade Lafer, conjugada ao prestigio das marcas Plastilan e Trorion.

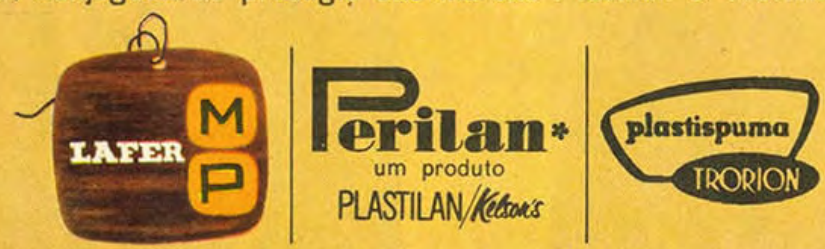




\section{MP-21}
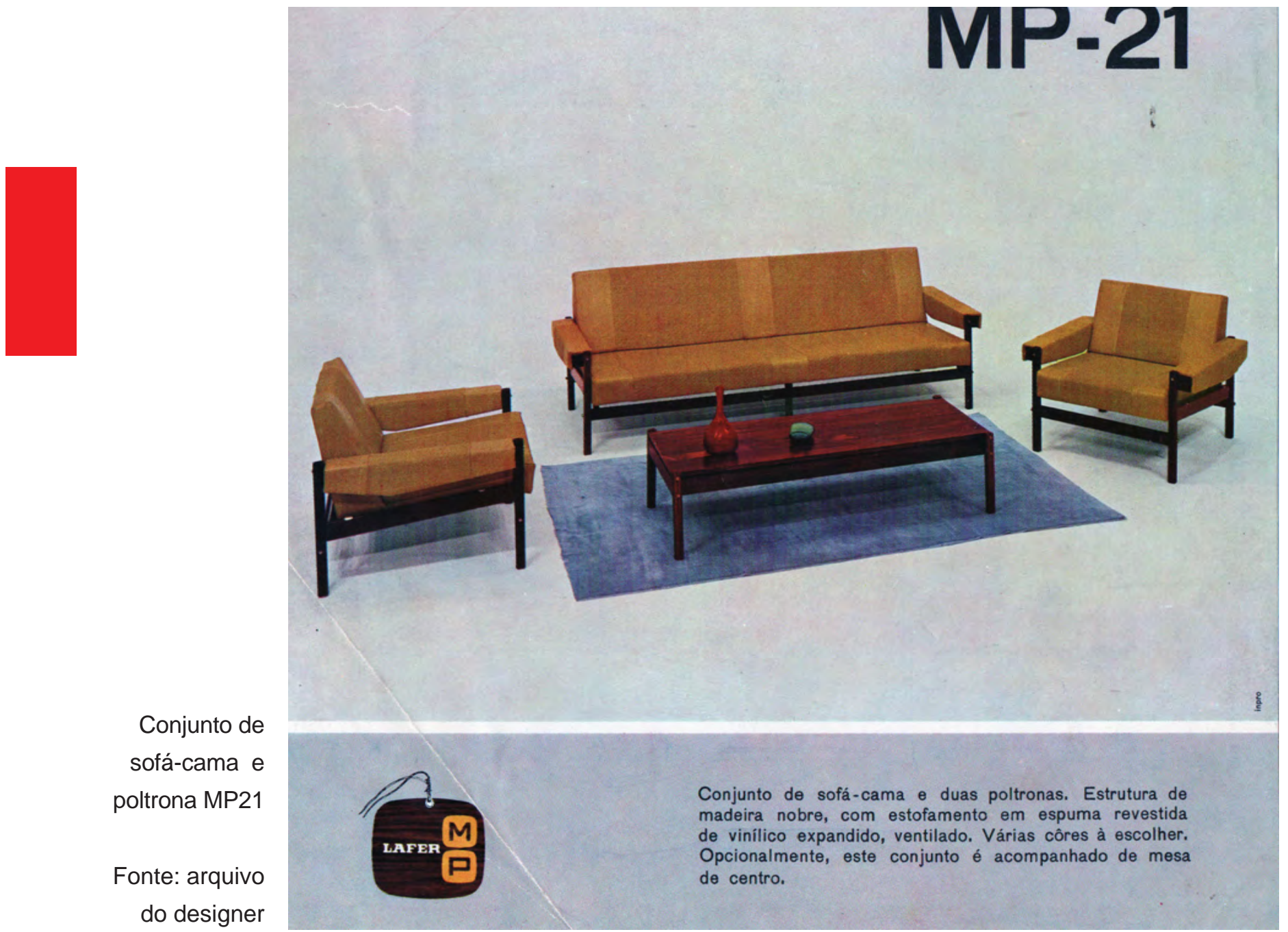

Conjunto de sofá-cama e poltrona MP21

Fonte: arquivo do designer

Conjunto de sofá-cama e poltrona MP31

Fonte: arquivo do designer

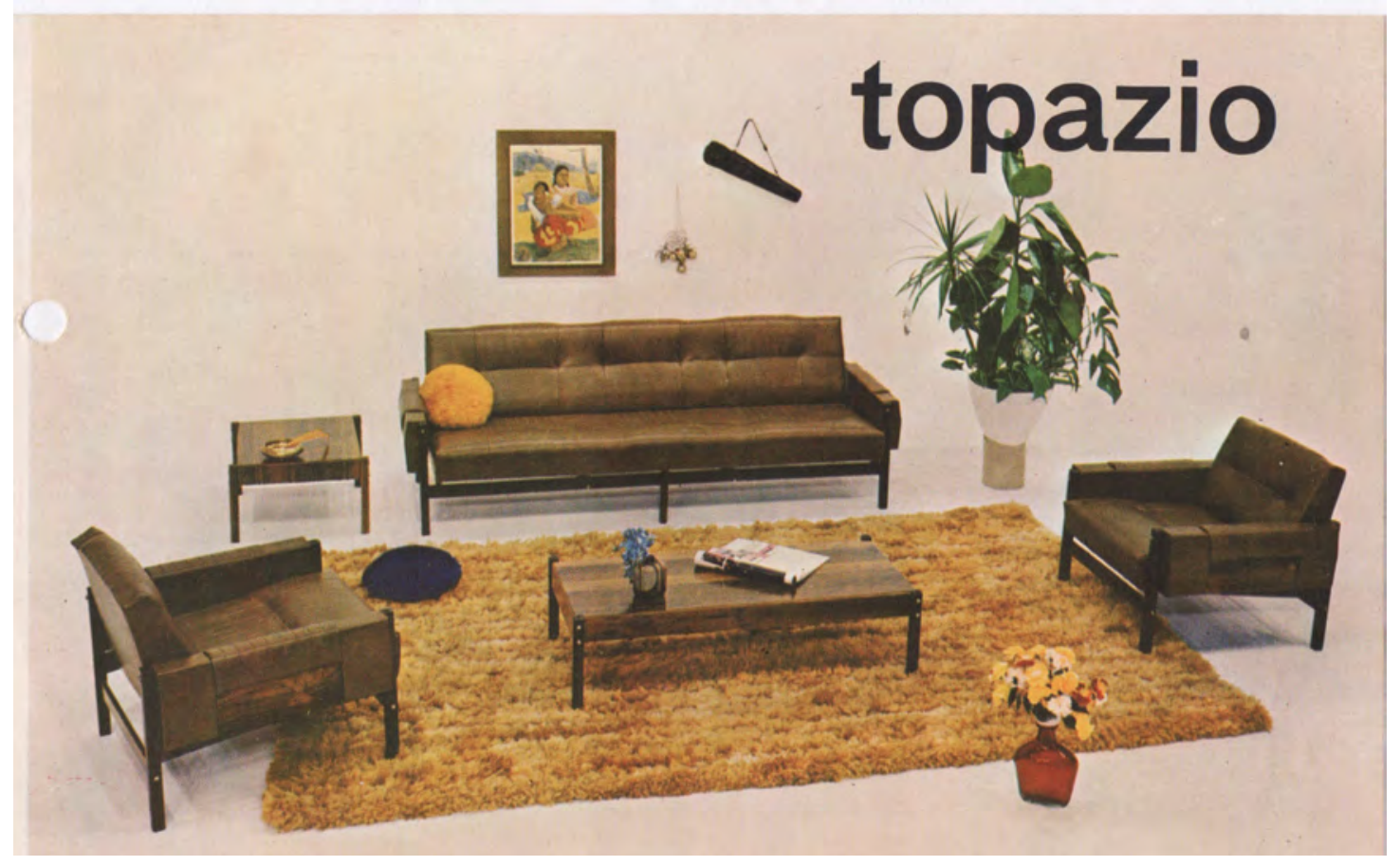




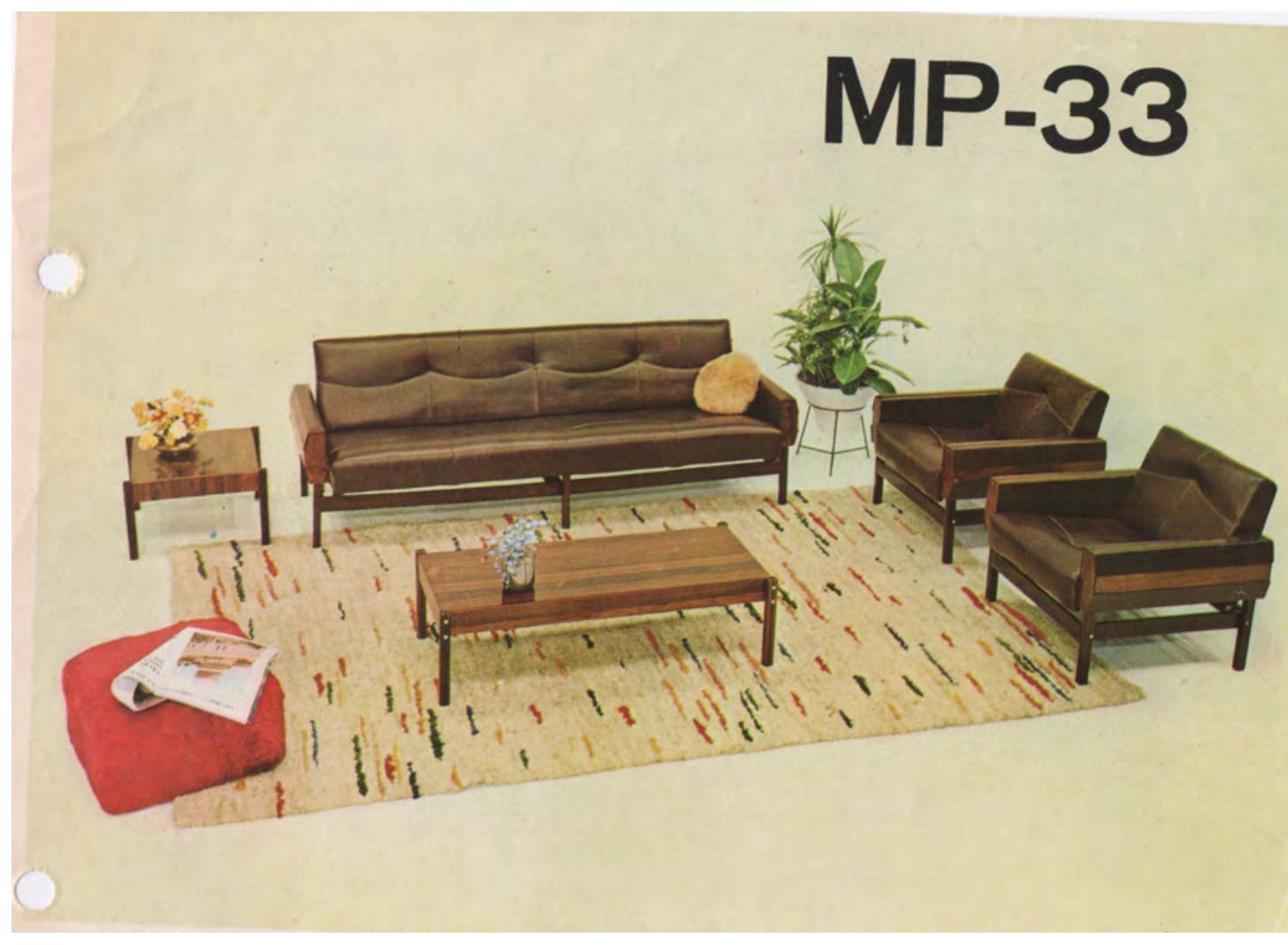

Conjunto de sofá-cama e poltrona MP33

Fonte: arquivo do designer

Conjunto de sofá-cama e poltrona MP37

Fonte: arquivo do designer 


\section{MP45}

O MP 45 apresenta outro tipo de solução articulável, empregada em muitas das linhas de sofá-cama desenvolvidas por Lafer. O sistema de encaixe e desencaixe se encontra no encosto e na lateral do sofá. O sistema é mais simples, e a cama se consolida com a união de elementos modularmente. Juntando as duas poltronas e o sofá de dois lugares, forma-se uma cama de casal de duas partes. O sofá apresentava duas mesas corrediças laterais. $O$ produto era popular, destinado aos pequenos espaços de habitação. $A$ poltrona passa a ser poltrona cama também, possibilitando a montagem de um módulo de solteiro. O conjunto apresentava ainda a opção de duas mesas laterais acopláveis em madeira ripada. Os módulos de apoio eram encaixados nos mesmos receptores metálicos, dispostos para os encostos.

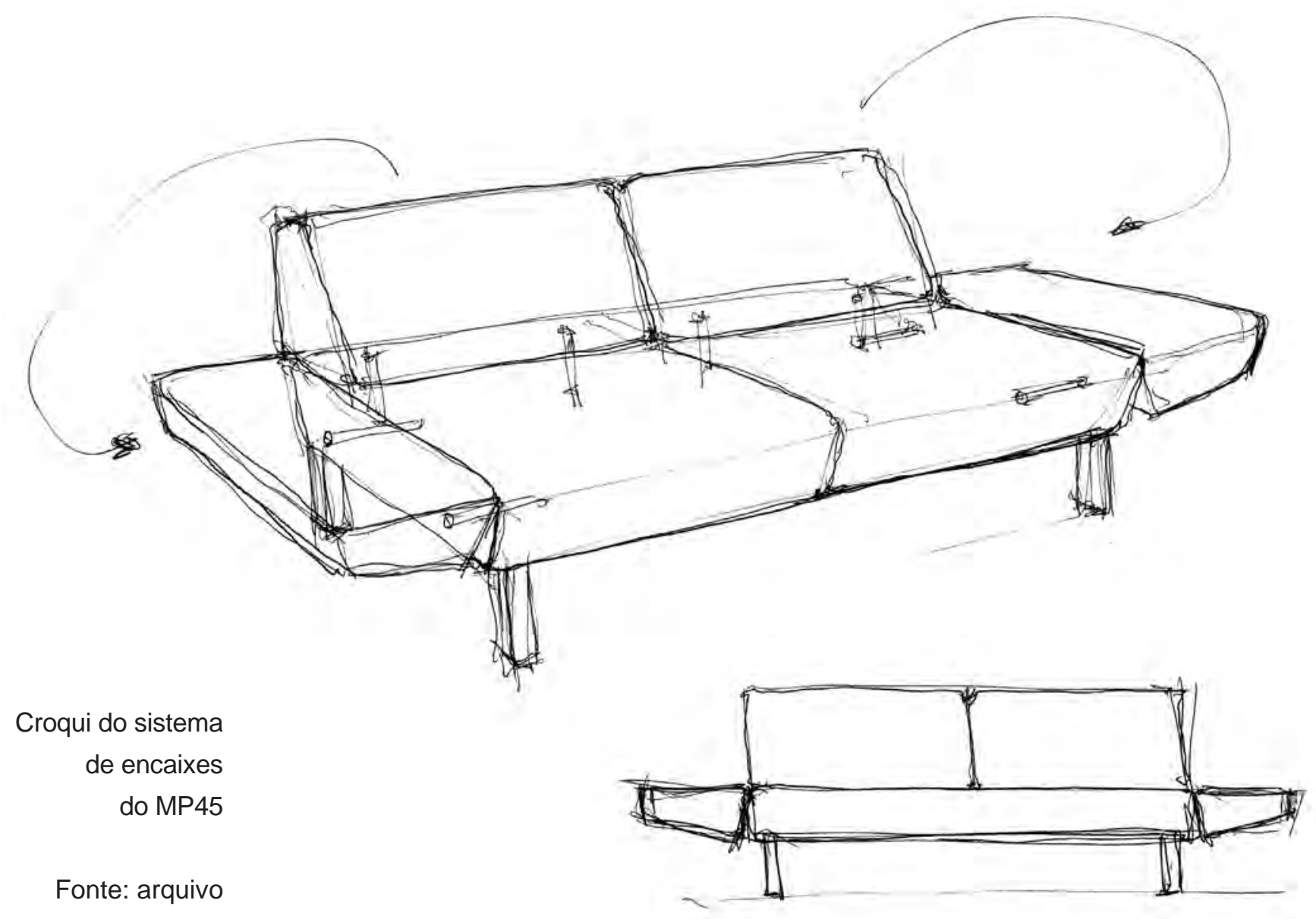

do designer 


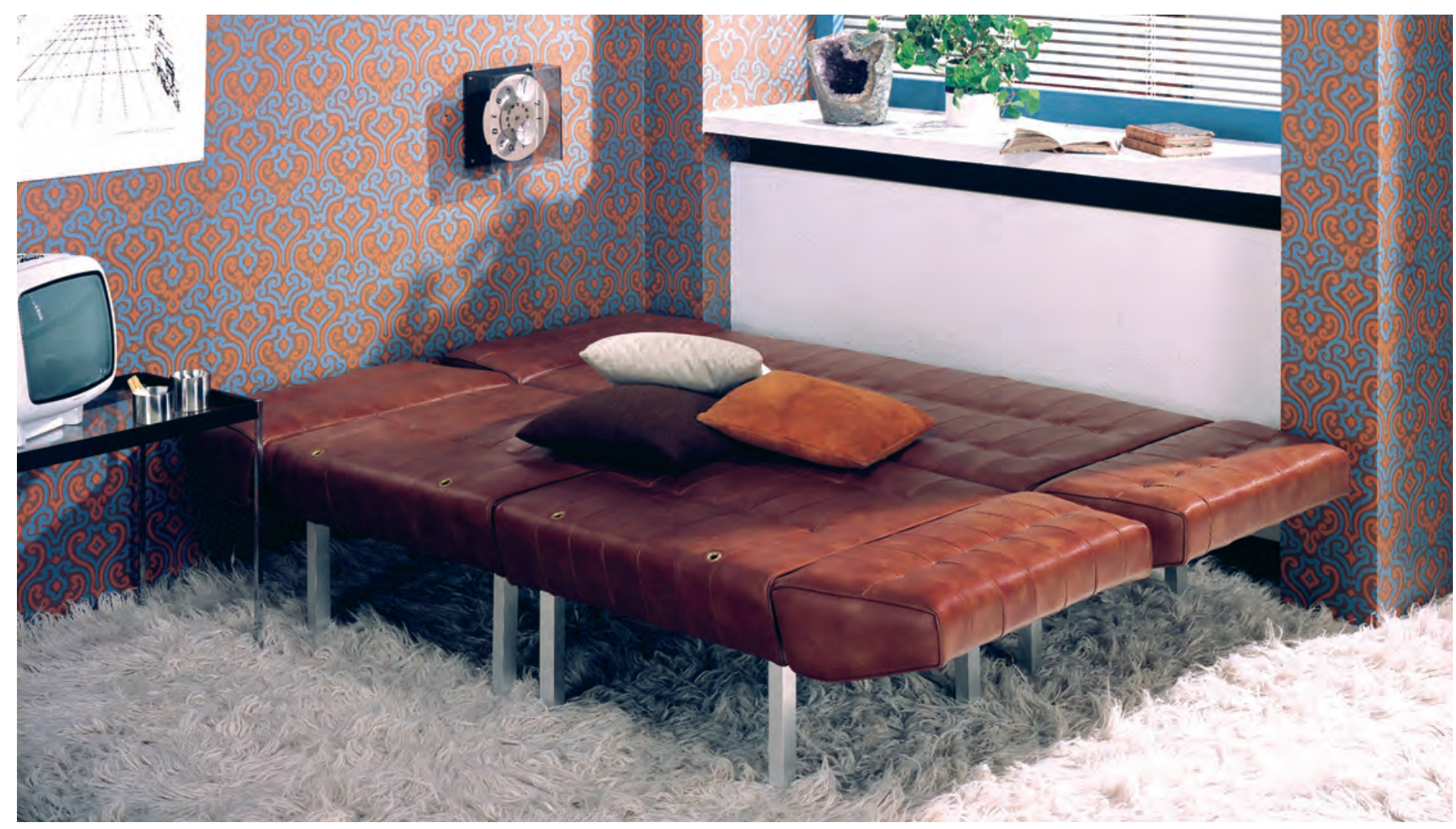

Conjunto MP45 em modo aberto. Fonte: arquivo do designer

$\oplus$

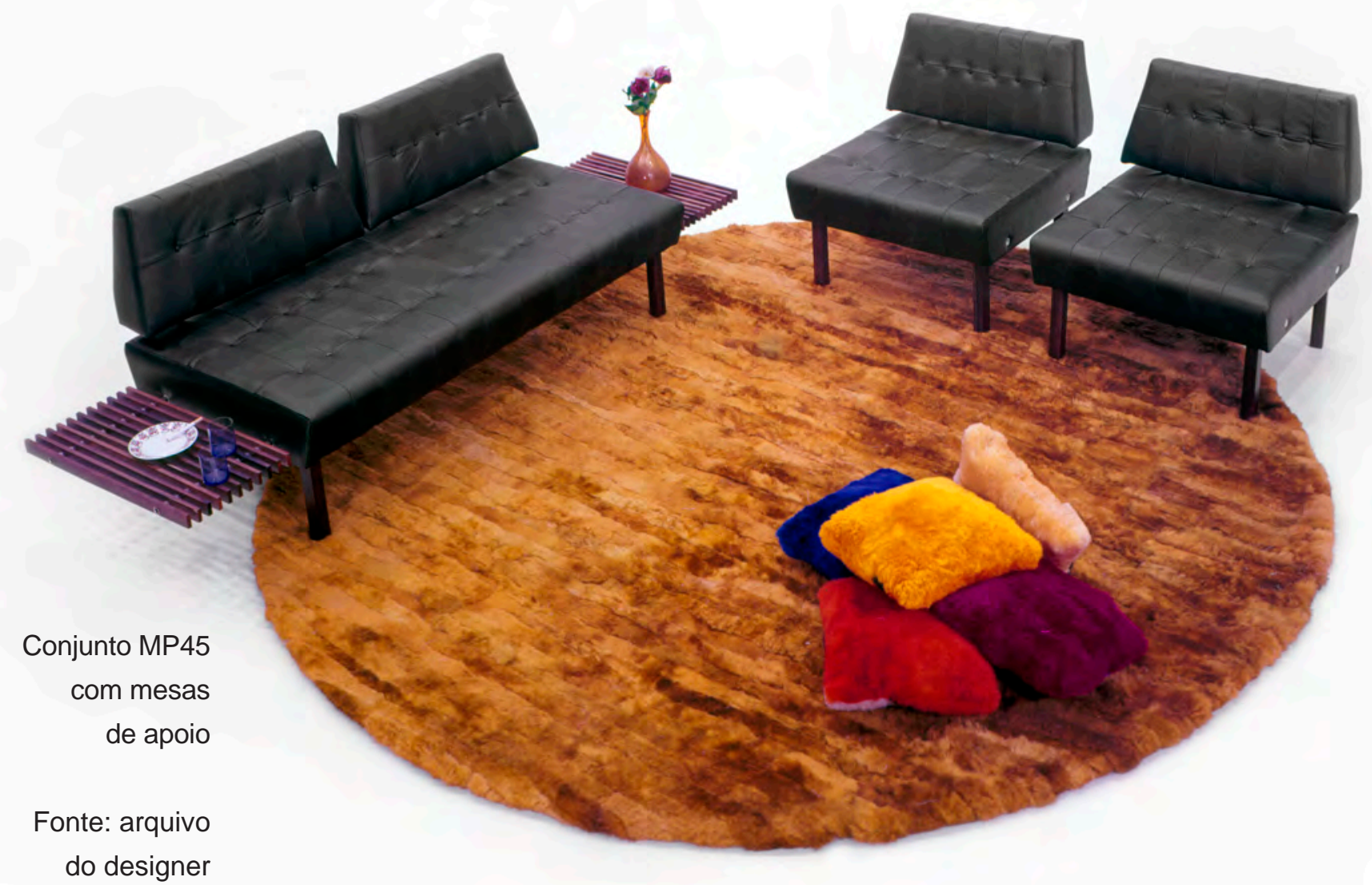




\section{MP77/ MP85}

Esses dois conjuntos diferem dos anteriores quanto a extensão do sofá. A cama, neste módulo, é aberta pelo arrastar do assento, juntamente com o braço, o que traz o encosto para formar o leito. A estrutura é deslizante para o sofá e basculante para as poltronas, o que se repete nos modelos subsequentes com algumas pequenas alterações, simplificações (no caso das linhas populares) e novidade formais. Essa experiência já havia sido feita anteriormente no MP27.

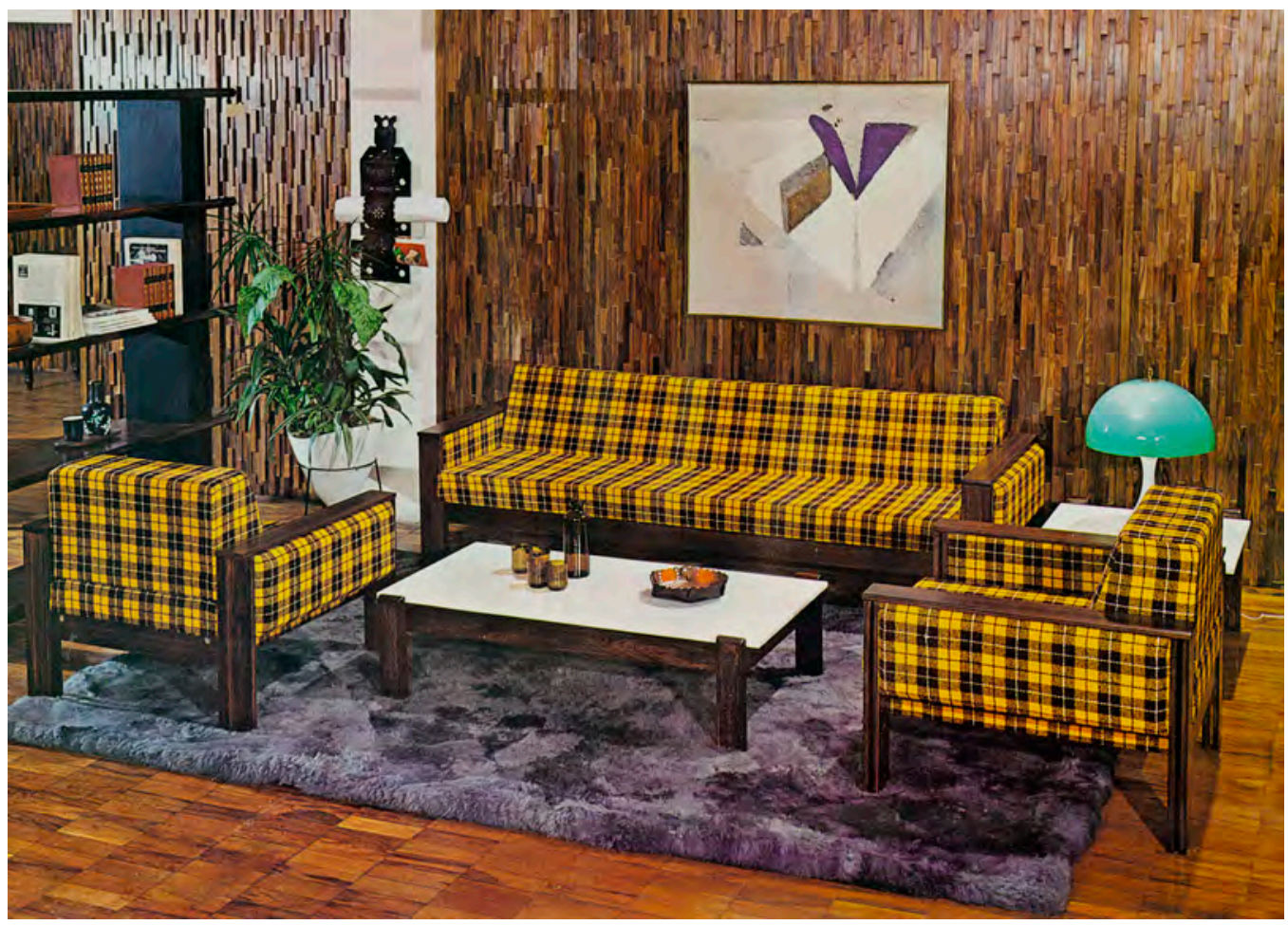

Conjunto de sofá-cama e poltrona MP77, com mesas de apoio e centro

Fonte: arquivo do designer
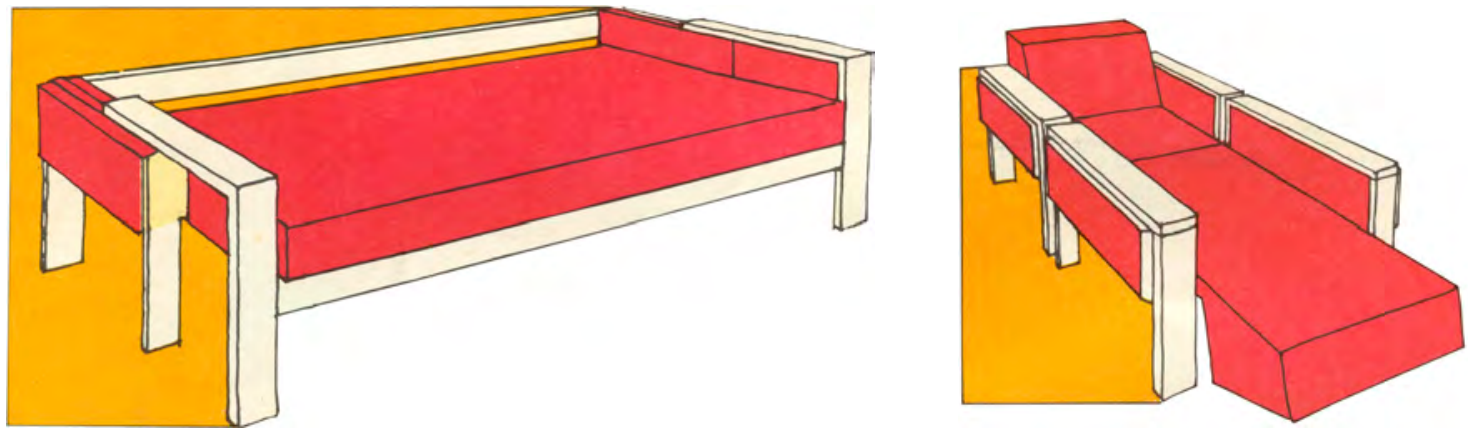

Desenhos esquemáticos do MP77 e sua abertura. Fonte: arquivo do designer 


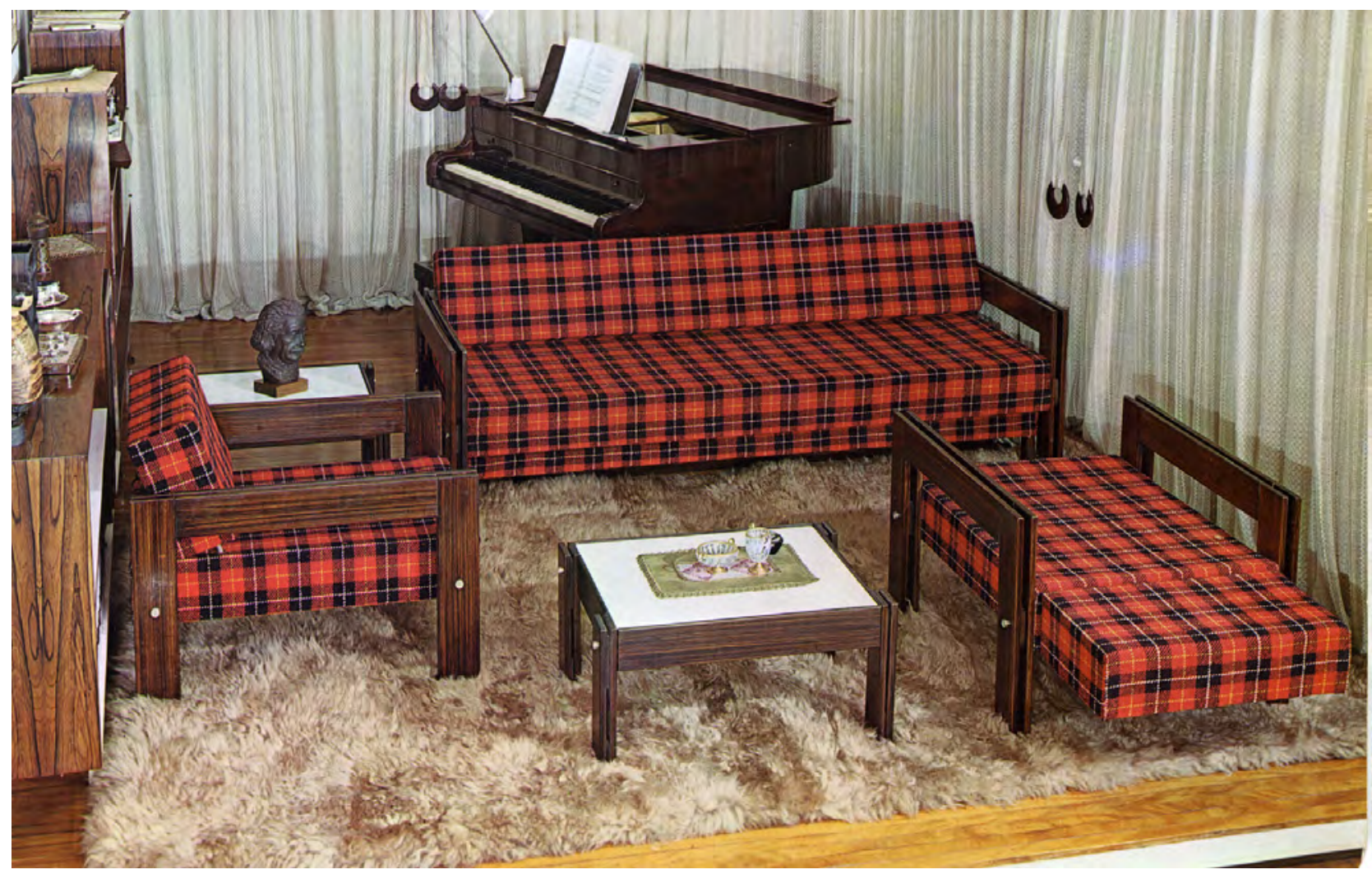

Conjunto de sofá-

cama e poltrona

MP 85 com mesas

de apoio e centro,

e poltrona aberta

Fonte: arquivo

do designer

Conjunto MP85

com mesas de

apoio e centro.

Fonte: arquivo do designer

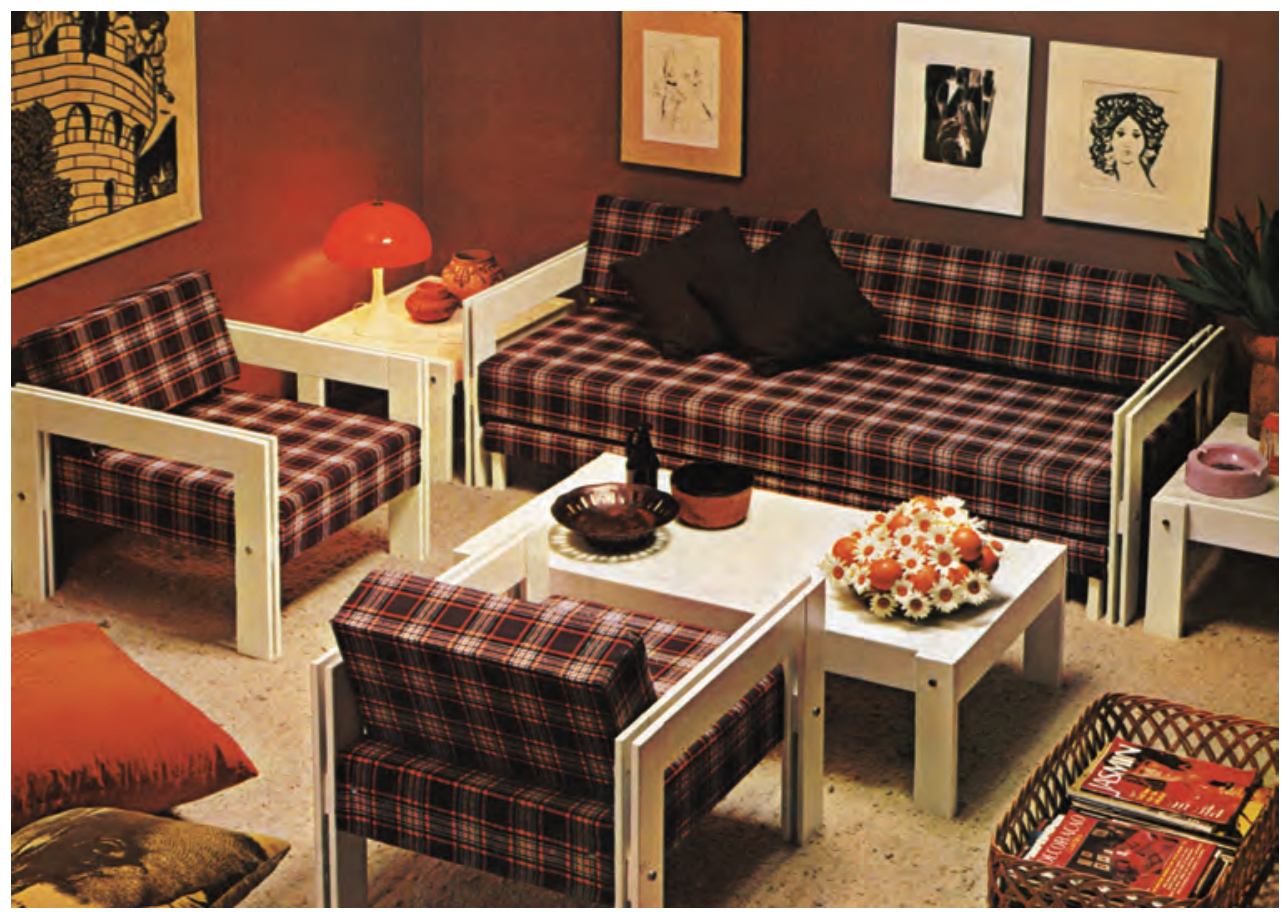


Outras linhas foram desenvolvidas, como o Sofanete, muito usado para mobiliar hospitais e casas de saúde, devido a sua

Sofá-cama

Montreal. O versatilidade. A mobilidade do encosto foi mantida, mas agora com estruturas articuláveis mais coesas e fáceis de manipular.

Nos anos 1980, foi lançada a linha MONTREAL e a HI-TECH, conjunto destinado às camadas mais jovens da população. De grande apelo plástico, alinha-se ao desenho da época, com inspiração em móveis que tinham como ponto de partida a forma mole da almofada e do puff. Essas formas foram muito exploradas no exterior por Vico Magistretti e Cini Boeri. O modelo construtivo perdurou até a atualidade com as linhas COMPAC.
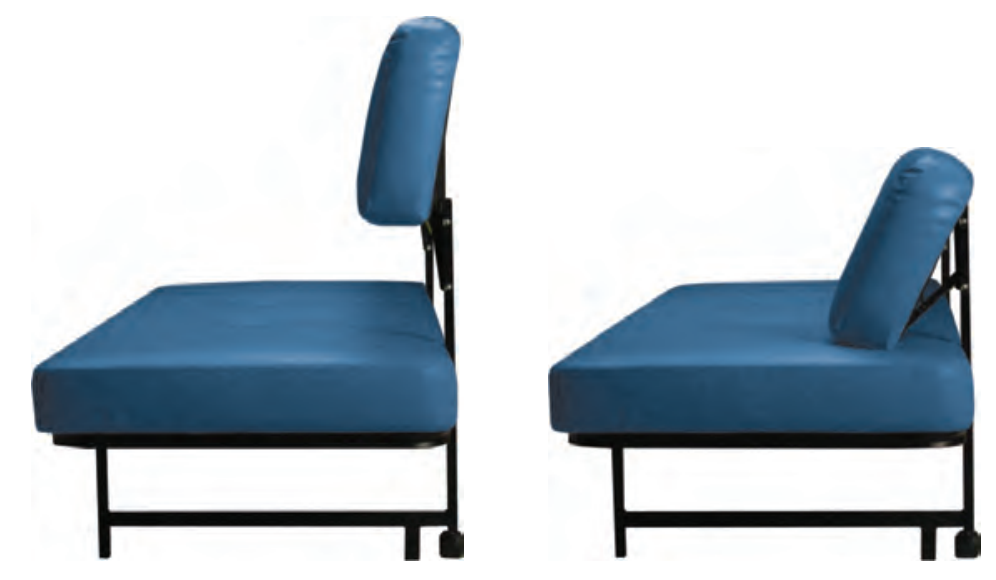

Vistas laterais e frontal do Sofanete.

Fonte: arquivo do designer estofado podia ser

combinados de diferentes formas

Sofá -cama HiTech. A linha seguia o mesmo principío da série Montreal

Fonte: arquivo do designer

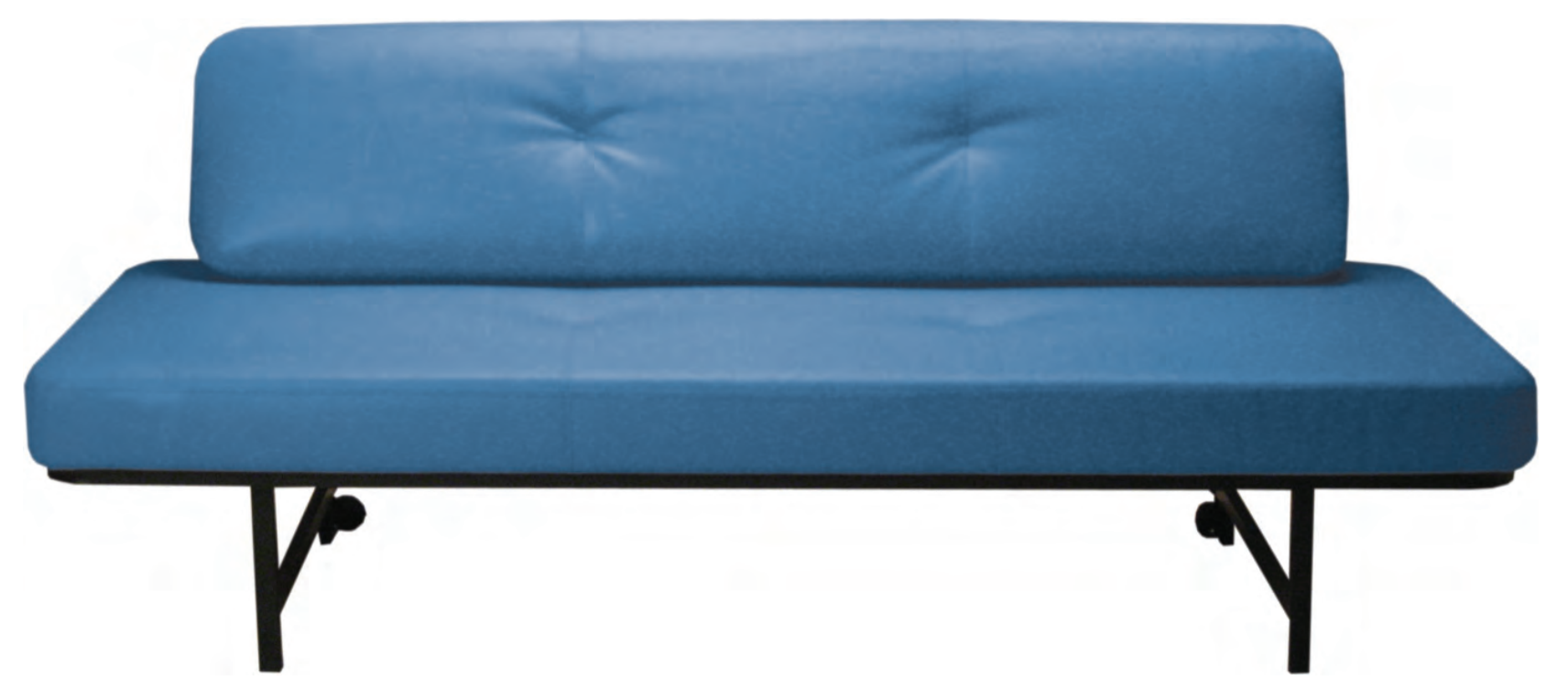



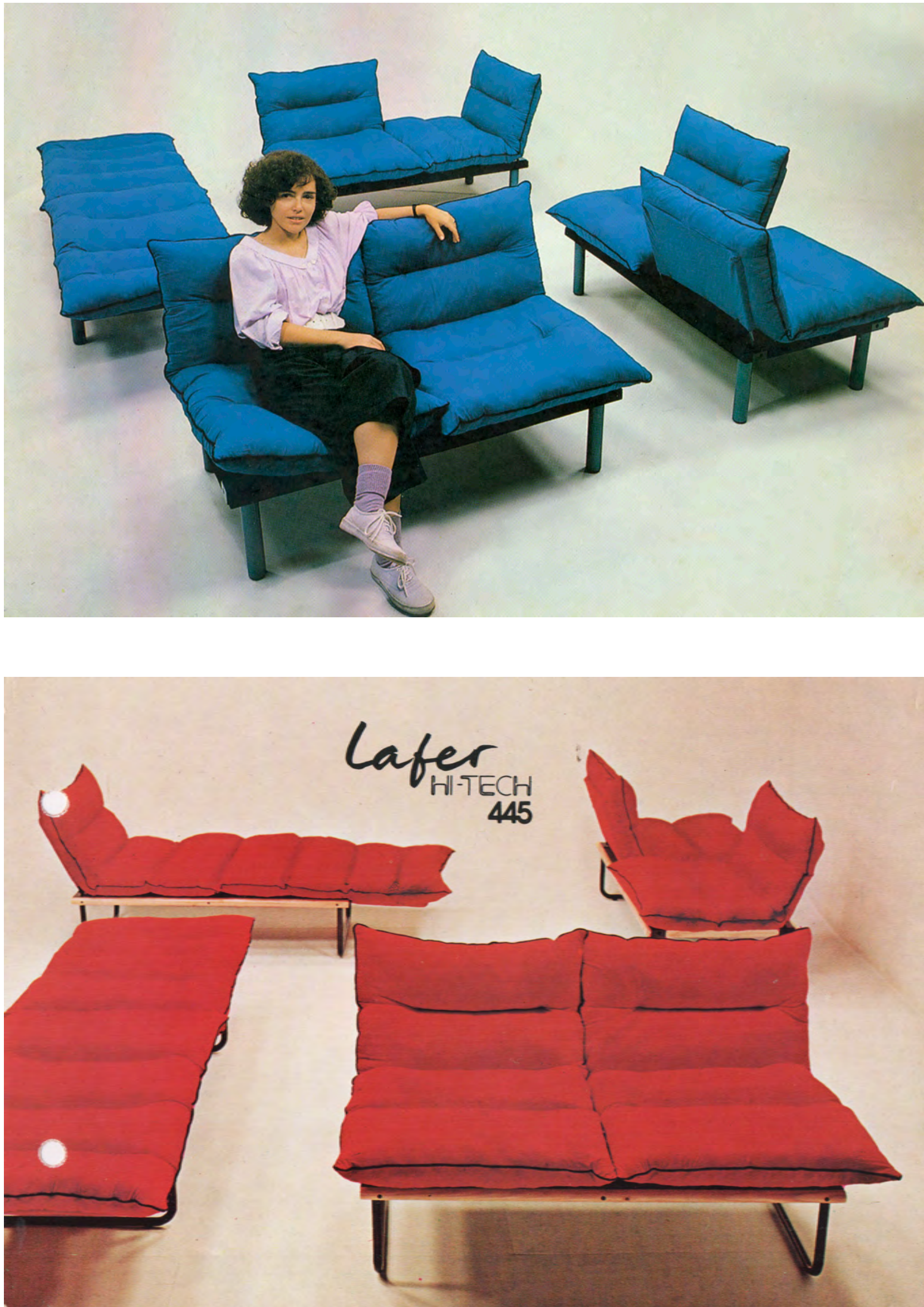


\section{SOFÁ-CAMA SAMBA}

SAMBA foi o nome escolhido para o sofá-cama lançado pela Lafer, em 1985. Simbolicamente, o nome, que faz referência ao movimento de abertura do sofá, alude à ginga do samba brasileiro. Todas as partes se desdobram. Conforme depoimento do designer: ${ }^{29}$

"O Samba tinha muitos diferenciais: o deslizamento do sofá para frente e para trás era obtido pelo simples acionamento de um pedal. Ao se deslocar para a frente, o encosto e a parte traseira do soáa, bem como sua parte frontal, pivotavam entre si, ficando todos alinhados na horizontal, formando a cama. O sistema permitia também a transformação da cama em chaise, levantando-se a parte traseira do sofá. $A$ articulação do estofamento era facilitada pela existência de gomos longitudinais, detalhe que também valorizava o sofá esteticamente."
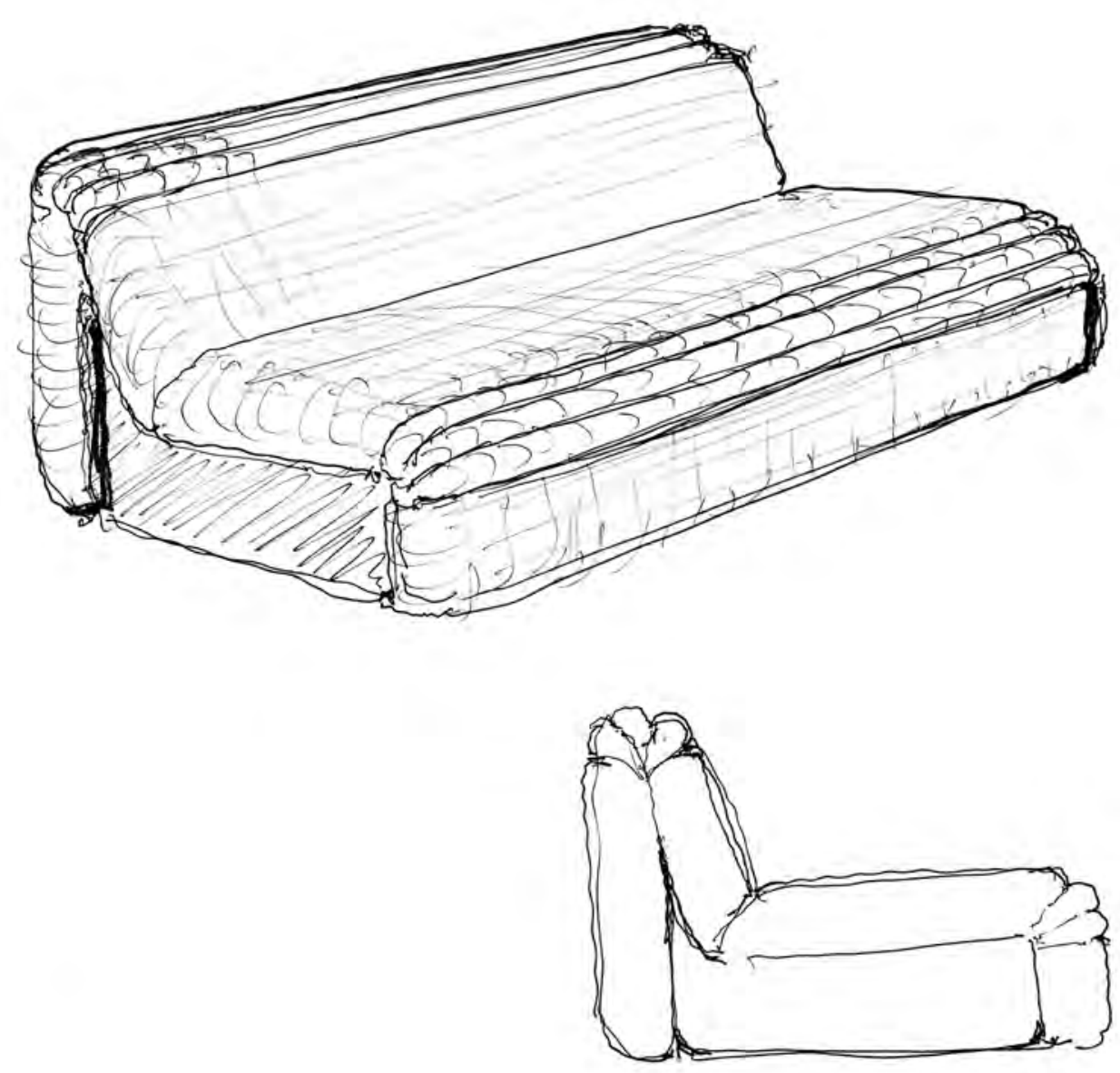

Croqui de Percival Lafer. Sofá-cama Samba fechado.

Fonte: arquivo do designer 
Sofá-cama

Samba fechado.

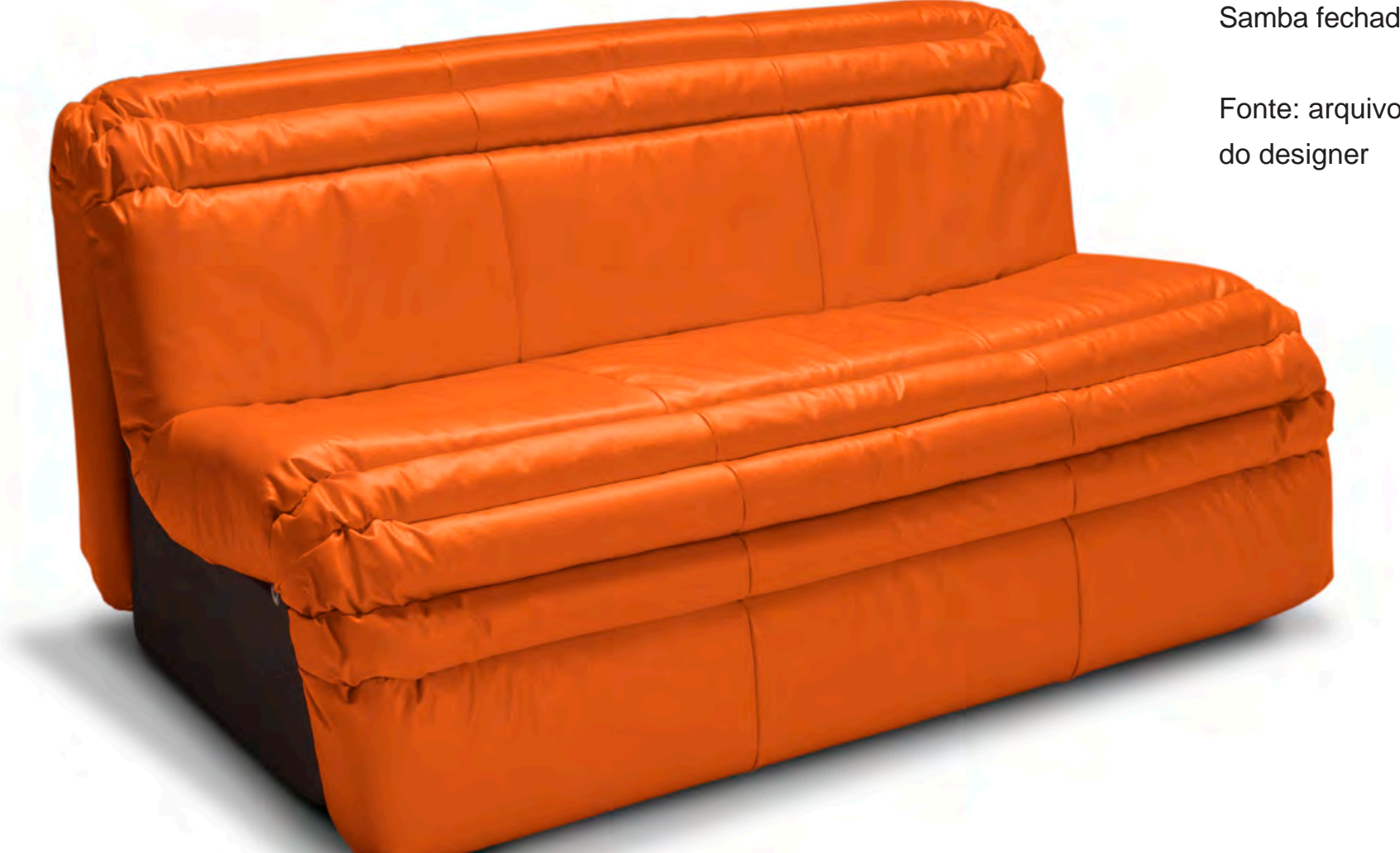

Estrutura articulável do sofá-

cama Samba, em aço,

$\oplus$

Fonte: arquivo do designer

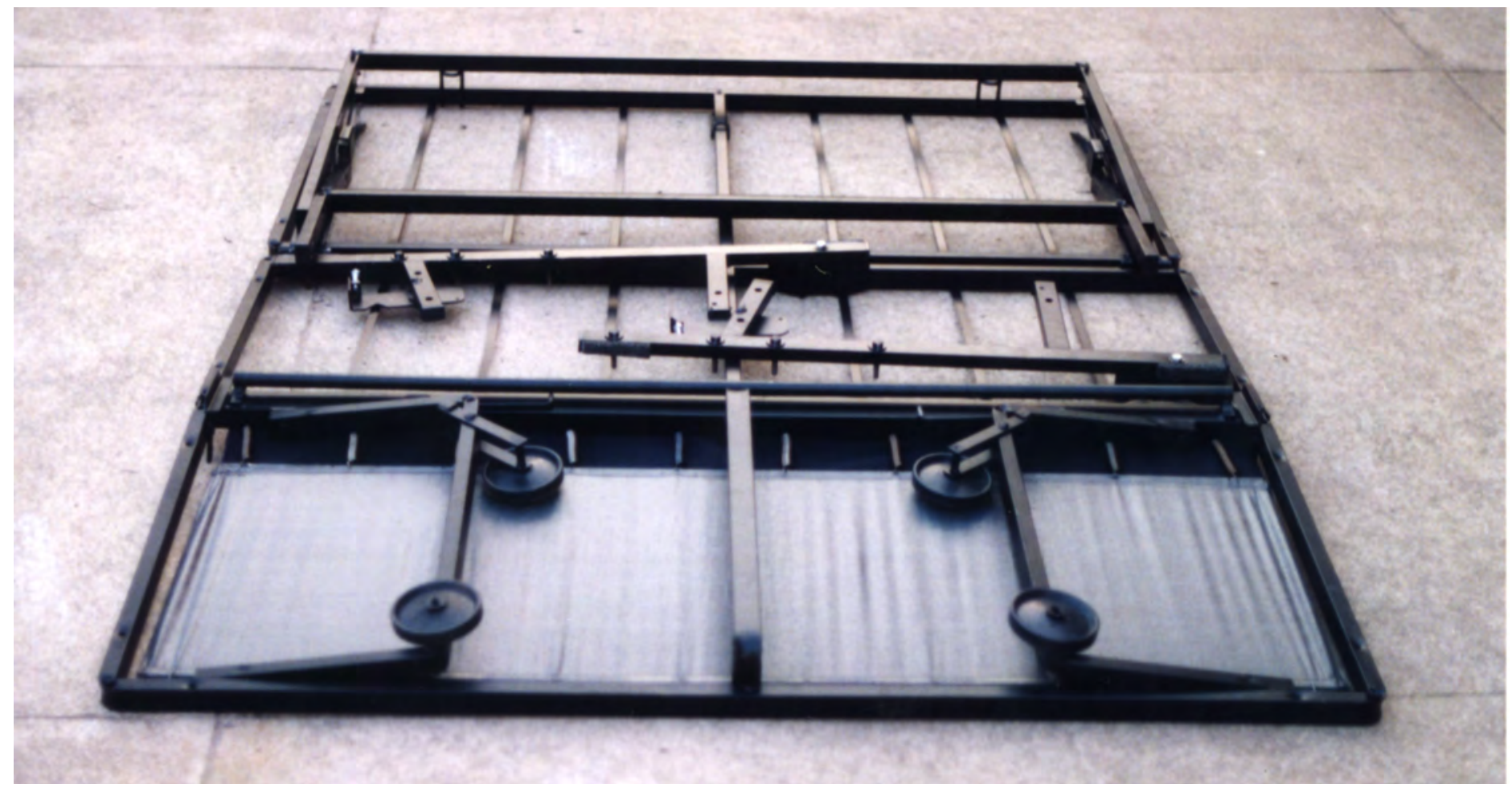



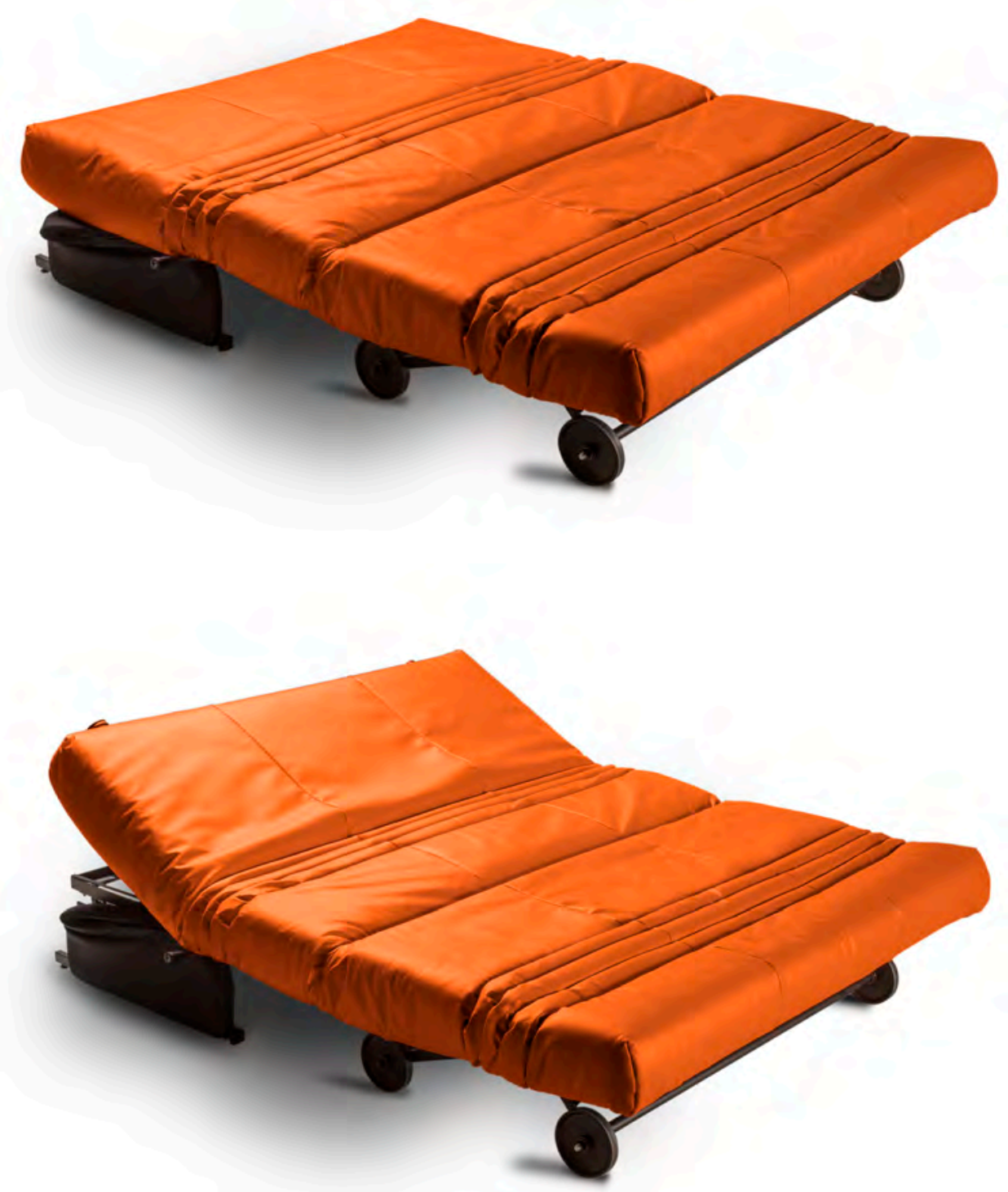

$\oplus$

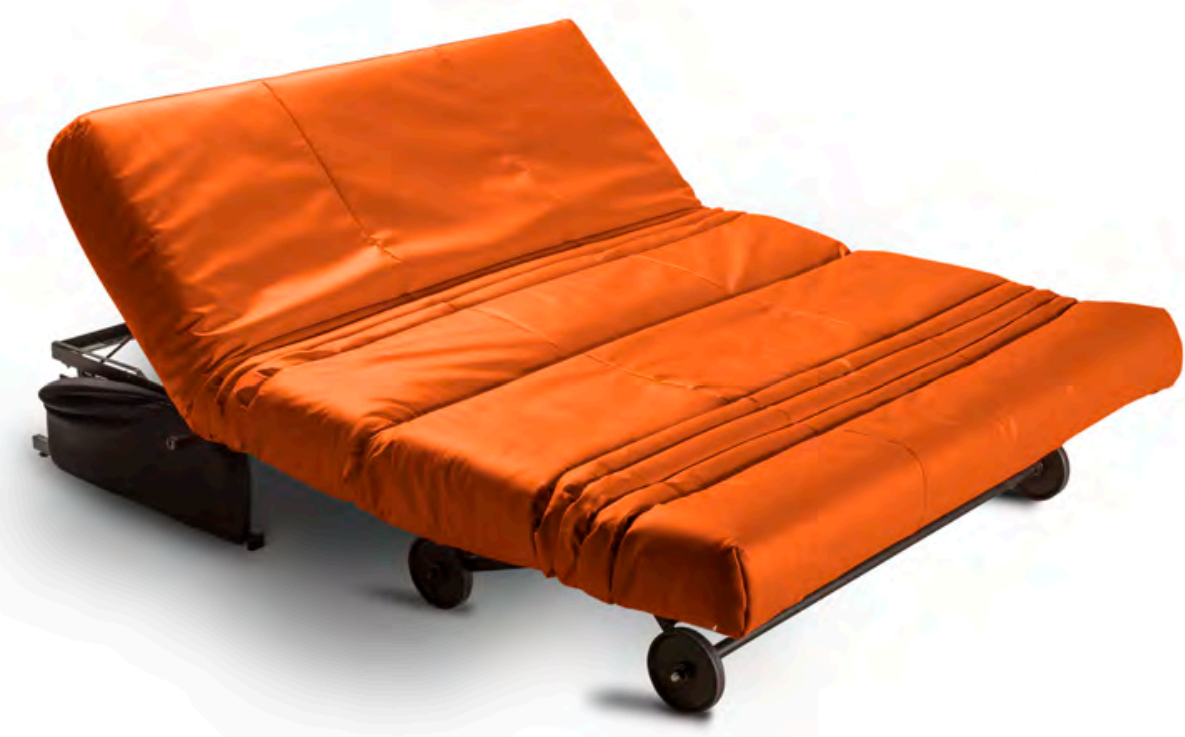

Série de fotos que explicitam o movimento do sofá-cama Samba.

Fonte: arquivo do designer 
O móvel era o prenúncio dos atuais home-theaters. Seu sistema articulado possibilitava várias inclinações do encosto. $\mathrm{O}$ produto era destinado primeiramente ao mercado nacional. Seu desenho era jovem e trazia consigo o conceito de despojamento do "futon" japonês. O mobiliário composto de almofadas era tendência no mundo inteiro, e influenciou a criação de Percival, principalmente no que diz respeito aos sofás-camas e reclináveis. O plano de assento, encosto e costas do sofá era único, e se desdobrava a partir de um eixo médio. Foi feita intensa campanha publicitária, tornando o produto um sucesso de vendas. Outras linhas precedentes seguiram o mesmo princípio estético, como é o caso das séries HI-TECH e MONTREAL.

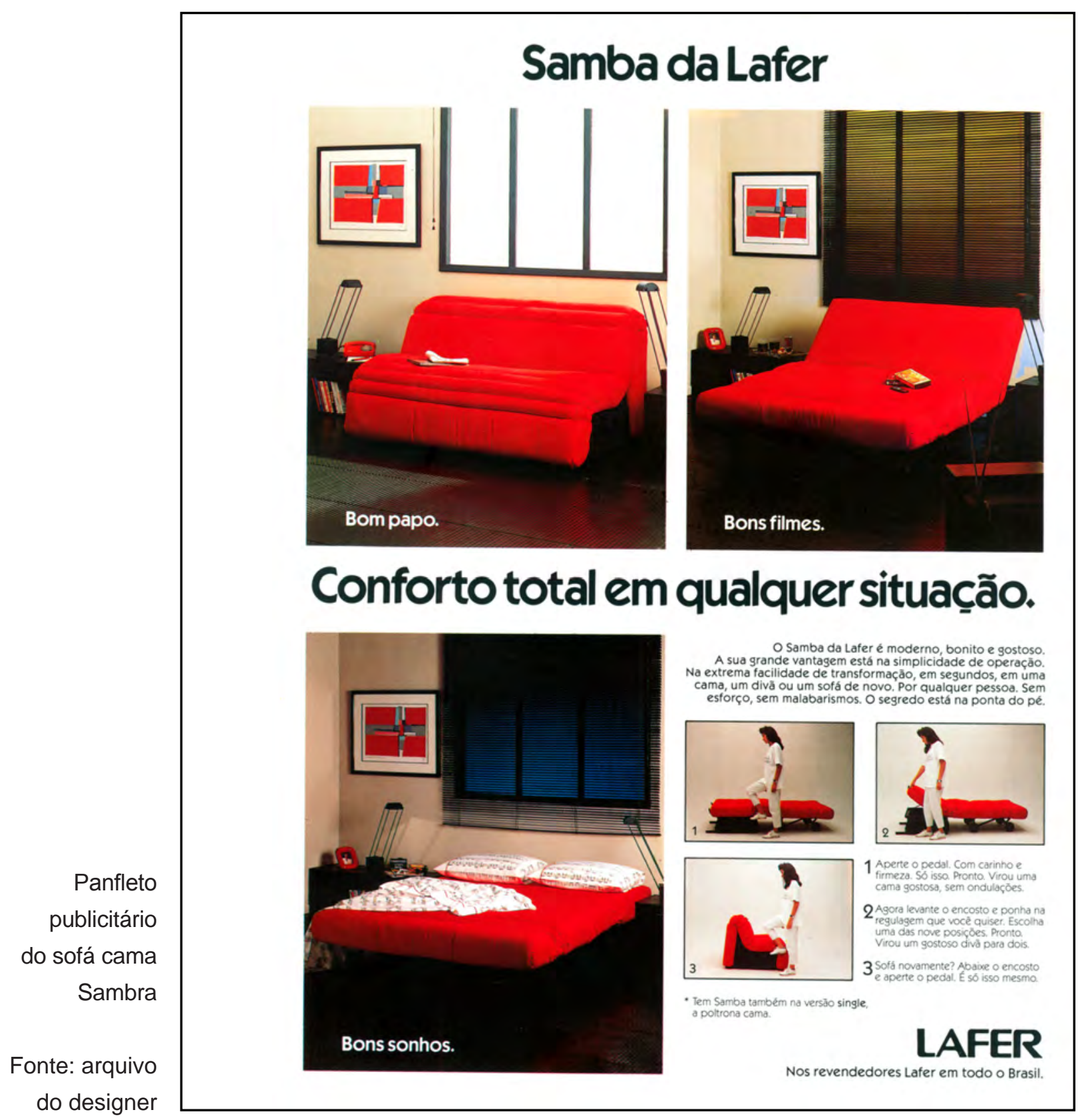




\section{FINAL 1 e 3 - LINHAS DE LUXO PARA A EXPORTAÇÃO}

Antes de começarmos a destrinchar os móveis pertencentes as linhas nomeadas com o final 1 e 3 , é importante dizer que o caminho traçado por Percival Lafer muitas vezes se mostrou o inverso do que comumente seria admitido enquanto processo criativo e de produção. Enquanto a maioria dos designers estavam fazendo adaptações de suas criações para a exportação, Percival estava criando primeiramente para o mercado externo, do qual a partir de 65, tornou-se cada vez mais íntimo. Grande parte dos modelos das linhas 1 e 3 foram criados para a exportação ou para o mercado nacional de luxo. É comum achar as peças em antiquários europeus, principalmente alemães. AAlemanha era o principal importador dos móveis de Lafer.

As peças que figuram nas próximas páginas podem ser consideradas as mais expressivas da carreira do designer. Neste caso, a poltrona parece ser sempre o ponto de partida do designer, do qual derivam os outros componentes (sofá e mesas laterais). Muitas das séries serão apenas poltronas, como é o caso da MP43 Mirage e MP71. O método a partir de um módulo unitário foi empregado por Lafer como forma de projetar e de direcionar a produção em série. Todas as peças foram produzidas industrialmente e possuem grande expressividade formal. Os componentes em madeira e metal eram todos beneficiados por máquinas, mesmo quando escultóricos. Há, como veremos, poucos elementos produzidos artesanalmente. Quando existentes, se encontravam, em sua maioria, concentrados no acabamento das peças e, principalmente, no estofamento em couro, que com detalhes preciosos, definiram a dimensão do luxo, tão apreciada pelos compradores das peças. Segundo o próprio Percival:

"[...]a intenção era criarum móvel que tivesse cara de artesanal, mas que fosse produzido de forma completamente industrializada. Todas as peças saíam daquele jeito das máquinas. O Mp41 foi criado para o mercado externo. Ele é um bom exemplo do que é uma industrialização com cara de artesanal. Os perfis saíam prontos das máquinas, por meio de uma ferramenta específica desenhada para produzir os componentes em grande quantidade." 30

30 Depoimento cedido ao autor. São Paulo, 09 de setembro de 2016. 
Sobre o uso do couro no revestimento ele completa:

"O estofamento em couro foi um desafio. O couro era de péssima qualidade nesta época. Como as peles eram pequenas, os estofamento era todo composto de pedaços pequenos de couro. As emendas eram acabadas artesanalmente. Isso era um dado importante, pois fazia parte na minha concepção, transformar o obstáculo em vantagem. Esse desenho do couro e a invenção dos detalhes enriqueciam a peça." ${ }^{31}$

A ordem de apresentação das peças respeitará a lógica construtiva, ora pelo uso dos mesmos componentes, ora pela mesma solução estrutural. Dessa forma conseguimos entender a chave do pensamento projetual do designer, bem como a organização produtiva e em série de seu mobiliário.

Vale ressaltar uma característica importante que pode ser observada na quase totalidade dos móveis que se seguem: as peças possuem um desequilíbrio tectônico forjado. Inclinações dos pés, o volume expressivo dos estofados e a estruturação nem sempre evidente provocam uma percepção particular das peças, que parecem a qualquer momento poder sucumbir a gravidade. Isso confere certo peso ao mobiliário. A estrutura parece estar em equilíbrio instável, muito característico dos móveis de Lafer. Embora esse recurso tenha sido usado por outros designers, como Sergio Rodrigues, em sua Poltrona Mole (o peso é distribuído da forma contrária daquela adotada por Lafer), ou mesmo pelos designers escandinavos do "midcentury", ele é conscientemente apurado em Percival Lafer, que faz desse aspecto um dos principais traços de seu estilo. 


\section{MP41}

O MP 41 inaugurou a fase de desenho amadurecido de Percival Lafer. Desenhado e produzido em 1968, o conjunto de sala é composto de poltrona, sofá de dois e três lugares e mesas laterais e de centro. A estrutura é composta por dois pórticos formados pela união dos pés de ripas ovaladas de jatobá maciço e dos braços tipo tora. Os braços recebem acabamento arredondado em duas faces e nos vértices, bem como nas duas extremidade das pontas. Os pés traseiros parecem transpassar os braços maciços. No entanto, pés e encosto, embora alinhados, são compostos por seções distintas. Essa estrutura é formada por travas horizontais de seção retangular presas pelos típicos parafusos sextavados e encapados desenvolvidos por Percival. As travas são chanfradas em sua ponta, recurso de junção para que os pés fiquem ligeiramente inclinados para fora, dando impressão de abertura por peso. Esse detalhe confere à peça uma qualidade de elegância despojada. Os componentes em madeira são todos usinados industrialmente. A essa estrutura são presas duas varas de aço cromado que sustentam a trama de percintas de sola, sobre a qual o estofado tipo almofadão repousa. Essa junção entre a estrutura primária e as hastes do estofado sofreram várias alterações durante os anos de produção. Foram usadas bandas de sola com botões de madeira, cavilhas percintadas e até rebaixo com gancho de metal.

O estofado em couro e espuma laminada apresenta uma hierarquia de costuras. Pespontos rebatidos e duplos são usados nas junções mestras do estofado, conferindo o ritmo do módulo (a poltrona sempre é o modulo base). Nos sofás, essa costura se repete a cada tanto, marcando o número de lugares. As costuras simples unem as outras partes menores, que, por modelagem geométrica, assentam a forma de concha. O repuxo é confeccionado com pequenas bandas de couro dando a impressão que cada ponto está ligado ao outro por essa fita. Em outro momento, pequenas fitas de couro são puxadas por meio de um fio de nylon, formando um pequeno laço em cada repuxo. As asas do estofado são confeccionadas com um tipo de acolchado, para que o volume do enchimento fique delicado nessa área do estofado e possa pender sobre a estrutura.

As mesas de apoio são formadas dos mesmos perfis de madeira com tampo de vidro. As banquetas seguem o mesmo princípio e

Vlista frontal e traseira da poltrona MP41.

Fonte: arquivo do designer 
acompanham, comumente, poltronas que recebem apoio de cabeça em estrutura particular. Todos os elementos eram desmontáveis e enviados ao exterior em caixas bem compactas. A largura das caixas não chegava a $20 \mathrm{~cm}$.

O MP 41 inaugurou, desta forma, um pensamento projetual produtivo utilizado em muitos outros móveis e linhas.
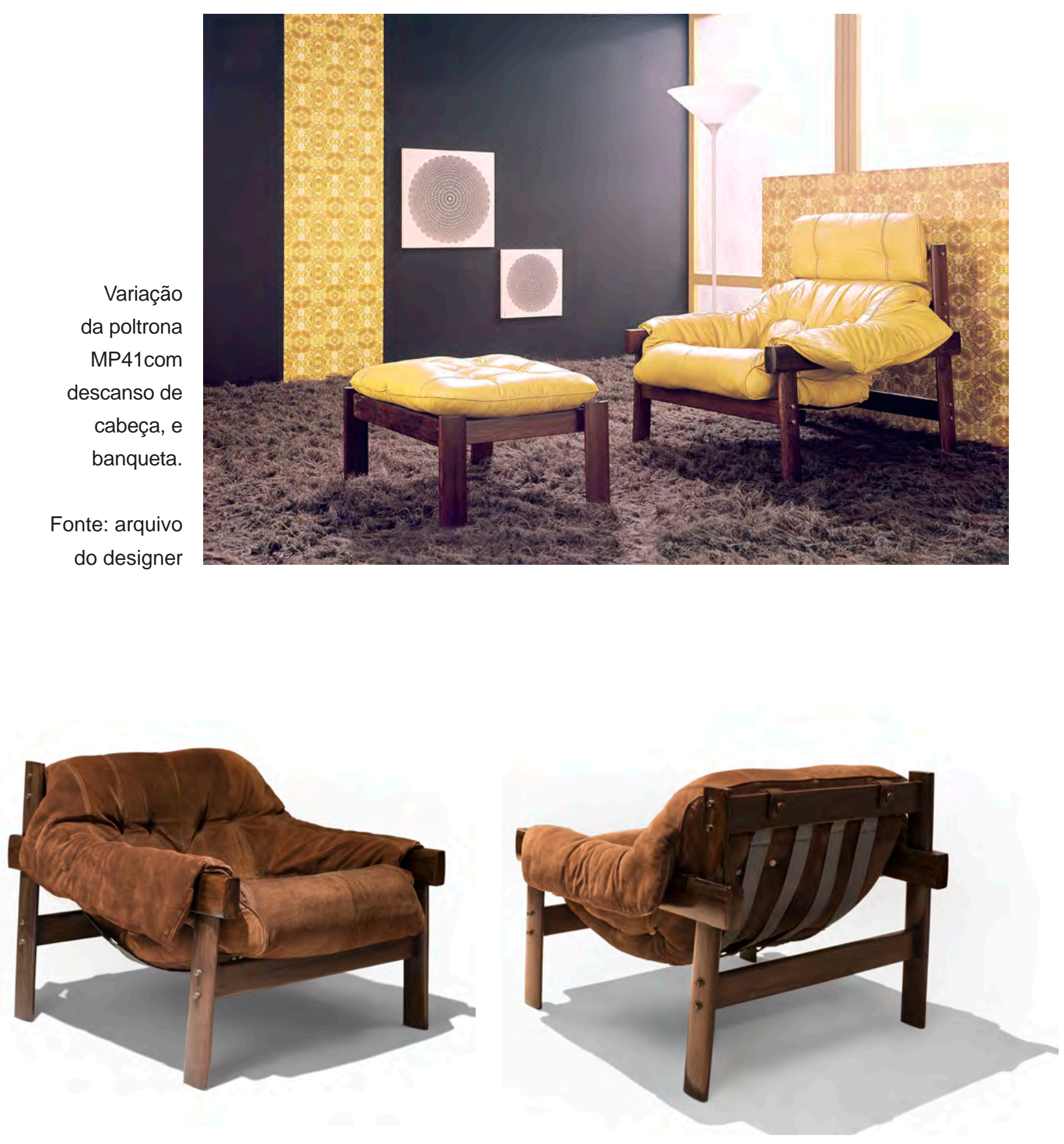


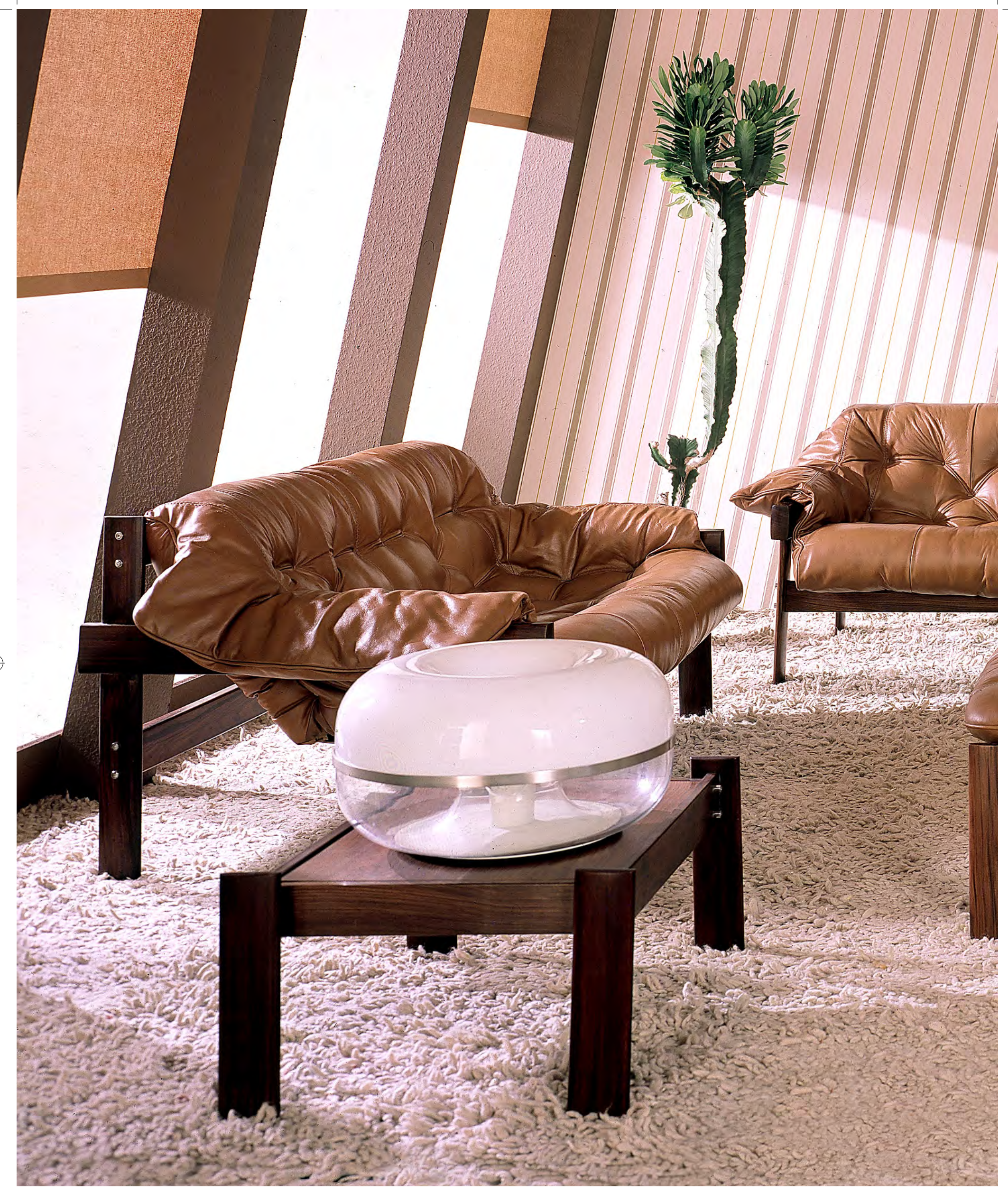




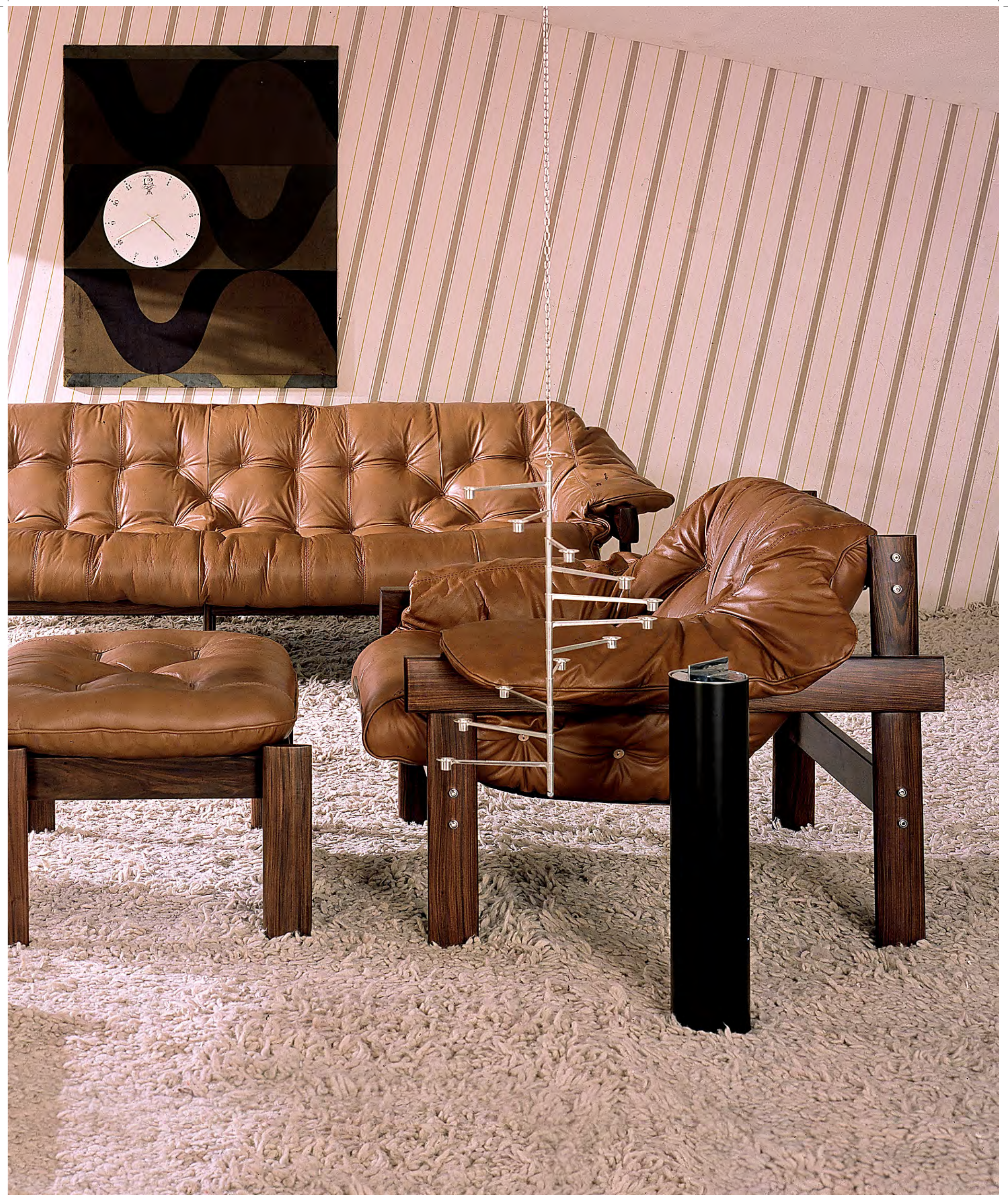

Conjunto de sofá. póltrona, banqueta e mesa MP41, ambientados

Fonte: arquivo do designer 


\section{MP51 (1970)}

O conjunto de sala de estar MP51, proposta austera e retilínea, é bem mais robusto e volumoso que o MP41 (as poltronas têm largura e profundidade de praticamente $100 \mathrm{~cm}$ ). Construtivamente, a estrutura obedece o mesmo partido projetual da série anterior: pórtico lateral unido por travas dianteiras e traseiras que sustentam o estofado solto por meio de um elemento percintado. Os componentes são praticamente os mesmos. Os perfis de madeira maciça ovalados obedecem agora duas dimensões: $9 \mathrm{~cm}$ para o pés e travas dianteiras e traseiras, e $15 \mathrm{~cm}$ para as travas laterais, sobre as quais eram fixados os braços soltos e estofados. Embora a concepção seja a mesma, o aspecto muda drasticamente com o rearranjo dos elementos comuns. Perfil dos braços e pés são fixados por cavilhas de madeira maciça perpassantes (em algumas versões essas cavilhas deixam de ser aparentes). Por sua vez, pórticos laterais e travas dianteiras e traseiras unem-se por meio de peças de aço inoxidável fundidas na forma do perfil, o que proporciona encaixe perfeito entre as partes. A junção das peças é realizada por parafuso aparente.

Poltrona MP51, e detalhe do encaise das peças de madeira macilça.

Fonte: arquivo do designer
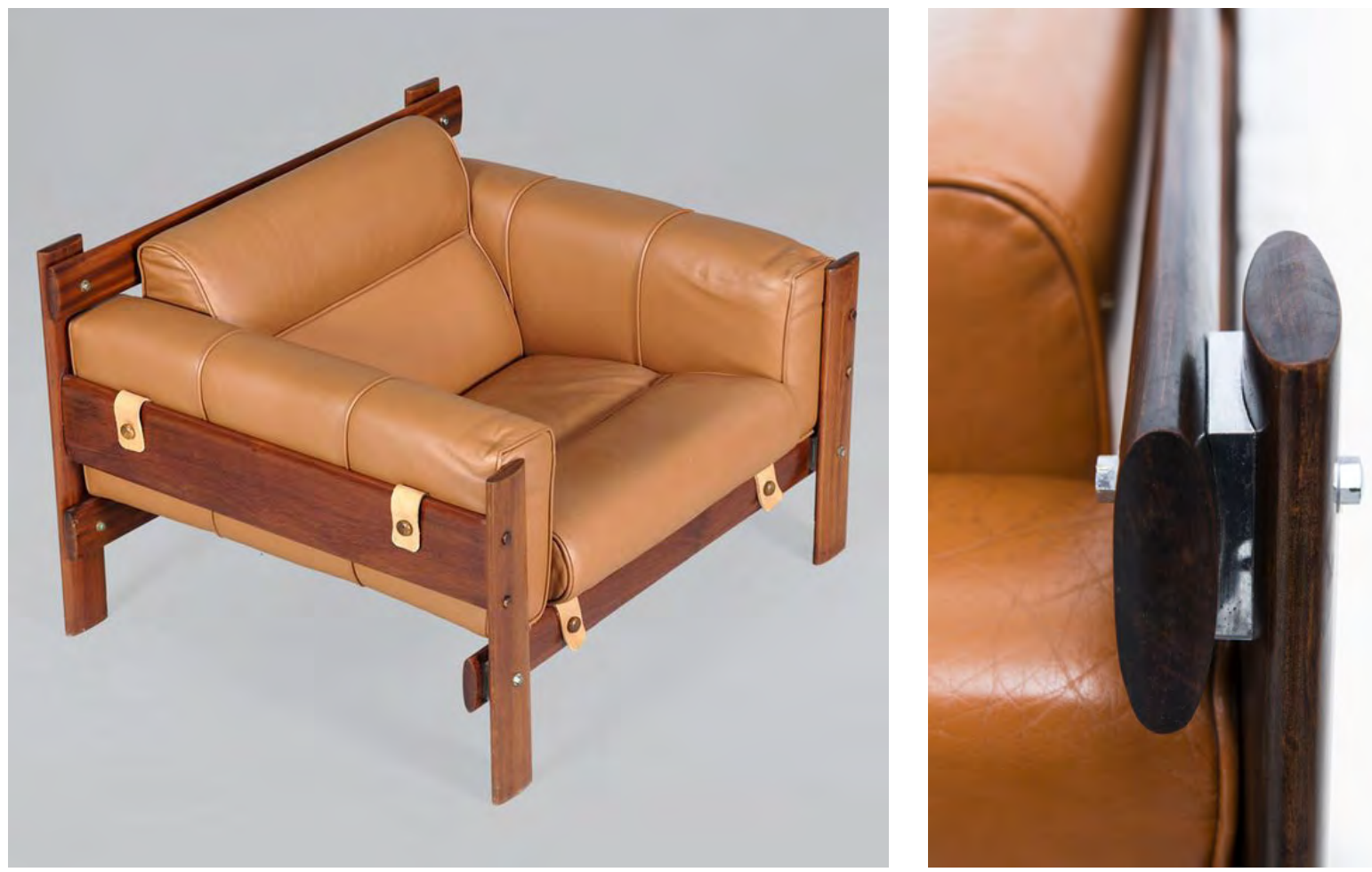
Conjunto de sofá, poltrona e mesa de centro MP51, ambientado
O estofado, dessa vez em espuma injetada, técnica amplamente explorada por Lafer, pousa sobre a estrutura sustentada por uma trama de percintas de sola presas a um bastidor e perfilado de aço redondo. Tanto essa base, quanto os braços serão fixados à estrutura de madeira, por meio de bandas de soleta rebitadas ao estofamento e à base, e presas à estrutura com pinos - botões de madeira. $O$ revestimento em couro recobre o estofado e é vincado por costuras e vivos em todas as junções.

Amesa de centro com tampo em mármore nacional carrarinha segue o mesmo padrão estrutural, apresentando os mesmos componentes de madeira e junção metálica entre as peças.

Nessa época, Percival já estava investigando o uso da fibra de vidro e, consequentemente, da espuma injetada em seus processos de produção e desenho. Os próximos móveis, em sua grande maioria, combinaram essas técnicas à marcenaria industrial.

Fonte: arquivo

do designer

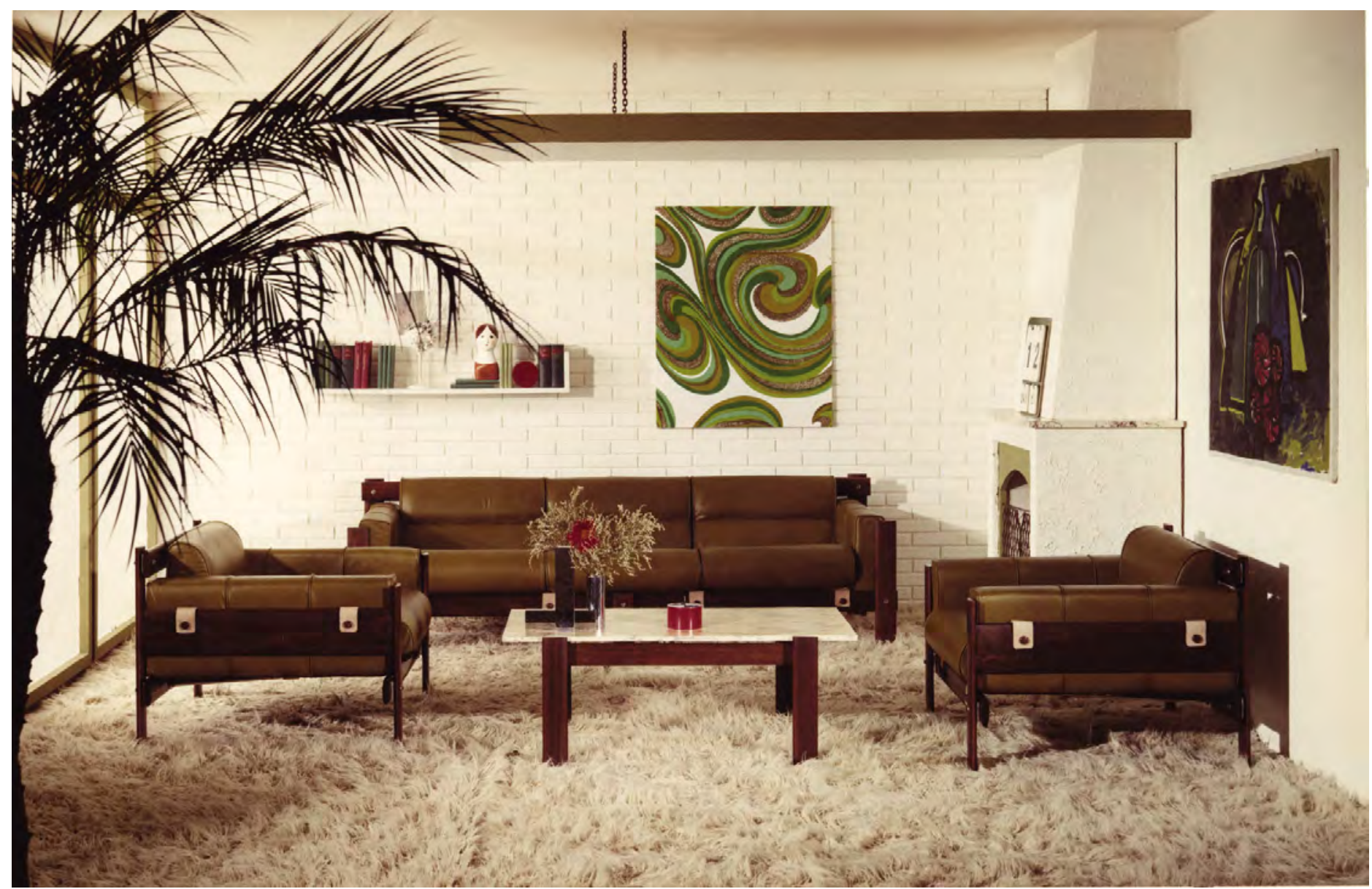




\section{MP 131 (1975)}

Os mesmo perfis ovalados utilizados nas travas de braço do MP51 agora formam a estrutura principal dos sofá e poltronas que compõem o MP131. Braço e pés formam um pórtico improvável, só possível pelo travamento em cantoneiras tipo "L", aparafusadas na junção dos componentes. Essas estruturas laterais, por sua vez, são unidas por um tubo metálico que as perpassa por meio de um parafuso especial com cabeça vincada em cruz. Essa estrutura suporta outro quadro metálico para o assento. Este quadro recebe um "zig-zag" de percintas de couro. As percintas também são usadas para sustentar a estrutura do assento, atirantando-se no tubo metálico traseiro.

O corpo feito em espuma injetada revestida de couro, e a modelagem em quadripartida com encontro em quadrado central, franzida nas costuras, conferiam volume ao conjunto. Os repuxos feitos por fitas de couro que se encontram em ilhoses aplicados sobre o revestimento. $\mathrm{Na}$ parte de baixo, a modelagem se encontra geometrizada, para acompanhar o formato da concha. Nas laterais inferiores, recebeu costuras largas em fita de couro, sugerindo um acabamento mais rústico, embora o estofado inteiro fosse costurado finamente. A curvatura das asas era conseguida por meio de um fino franzido na parte superior do elemento em couro.

As mesas de centro e escabelo seguiam o mesmo partido estrutural da MP41, variando apenas a inclinação dos pés e o estofamento. O tampo também era diferente, sendo, nesse modelo, em vidro serigrafado preto.
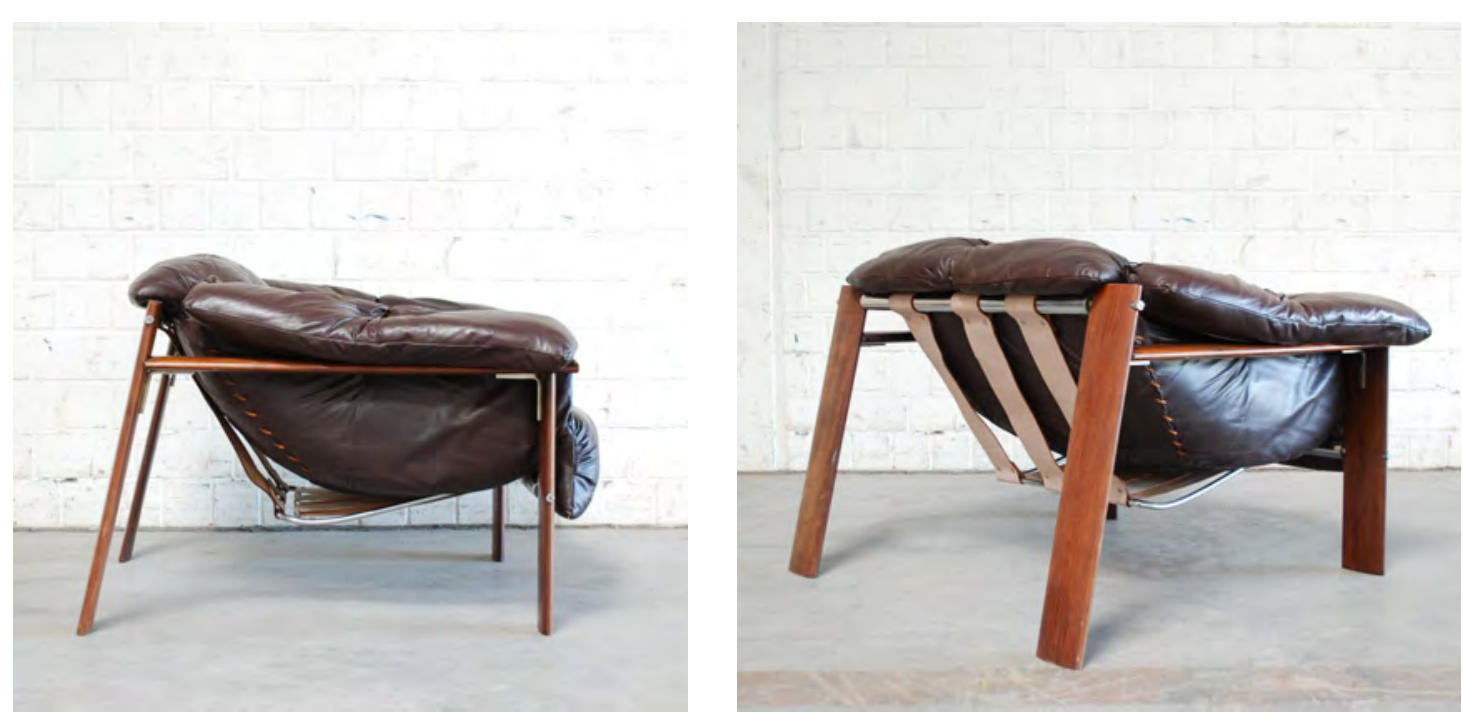

Vlista lateral e traseira da poltrona MP131.

Fonte: arquivo do designer 


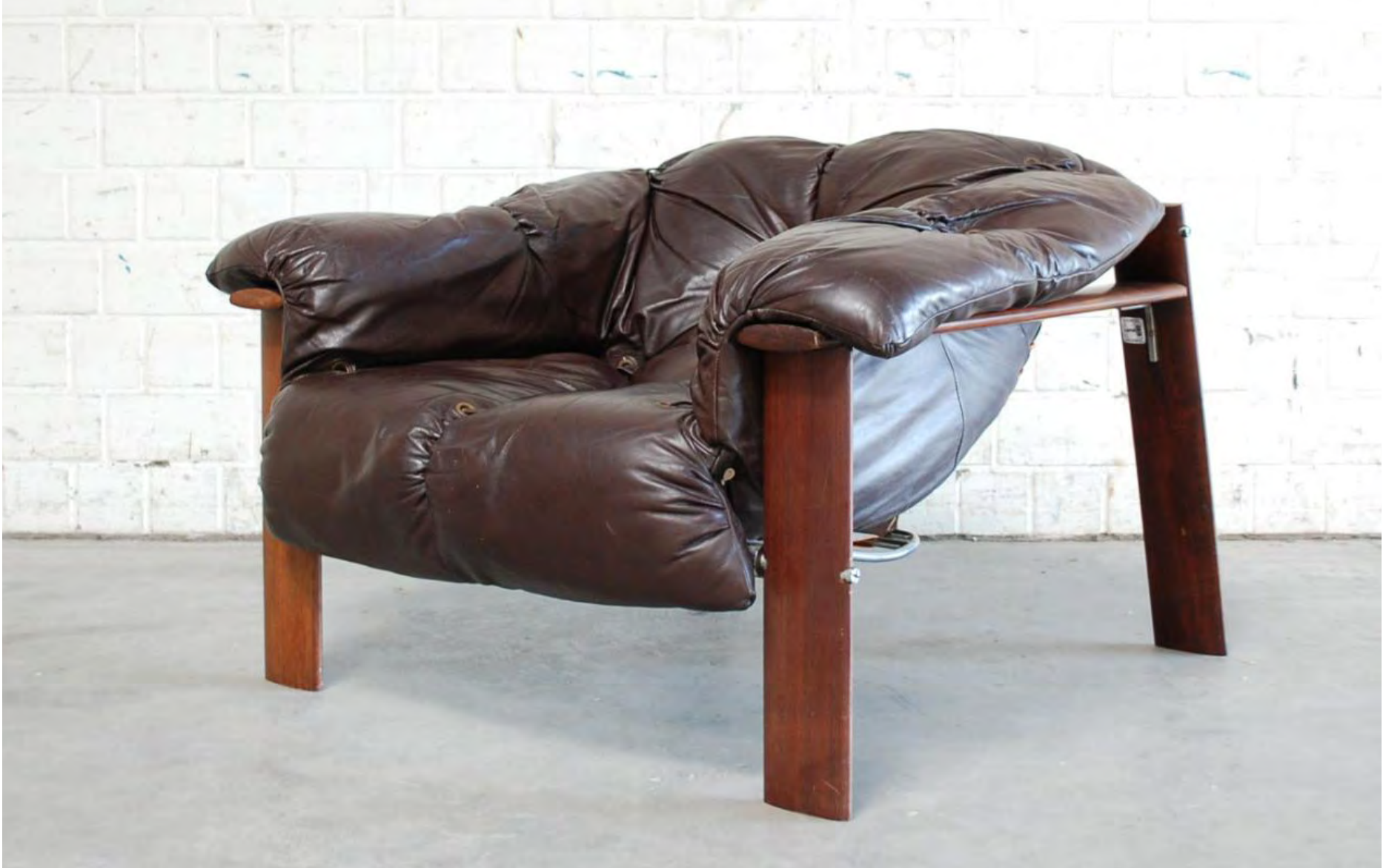

Vista frontal da poltrona MP131

Detalhe da estrutura, poltrona MP131.

Fonte: arquivo do designer

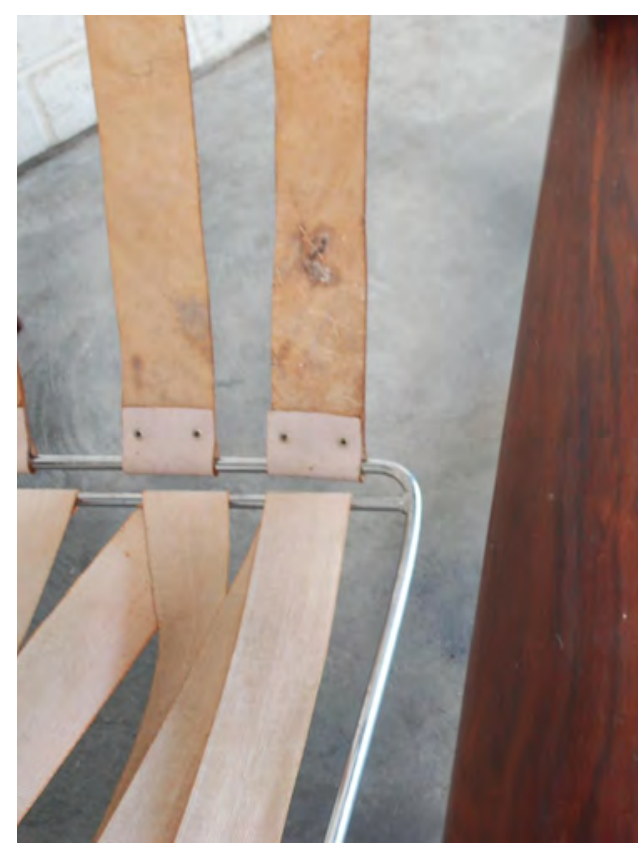

Estrutura da poltrona MP131.

Fonte: arquivo do designer
Fonte: arquivo do designer

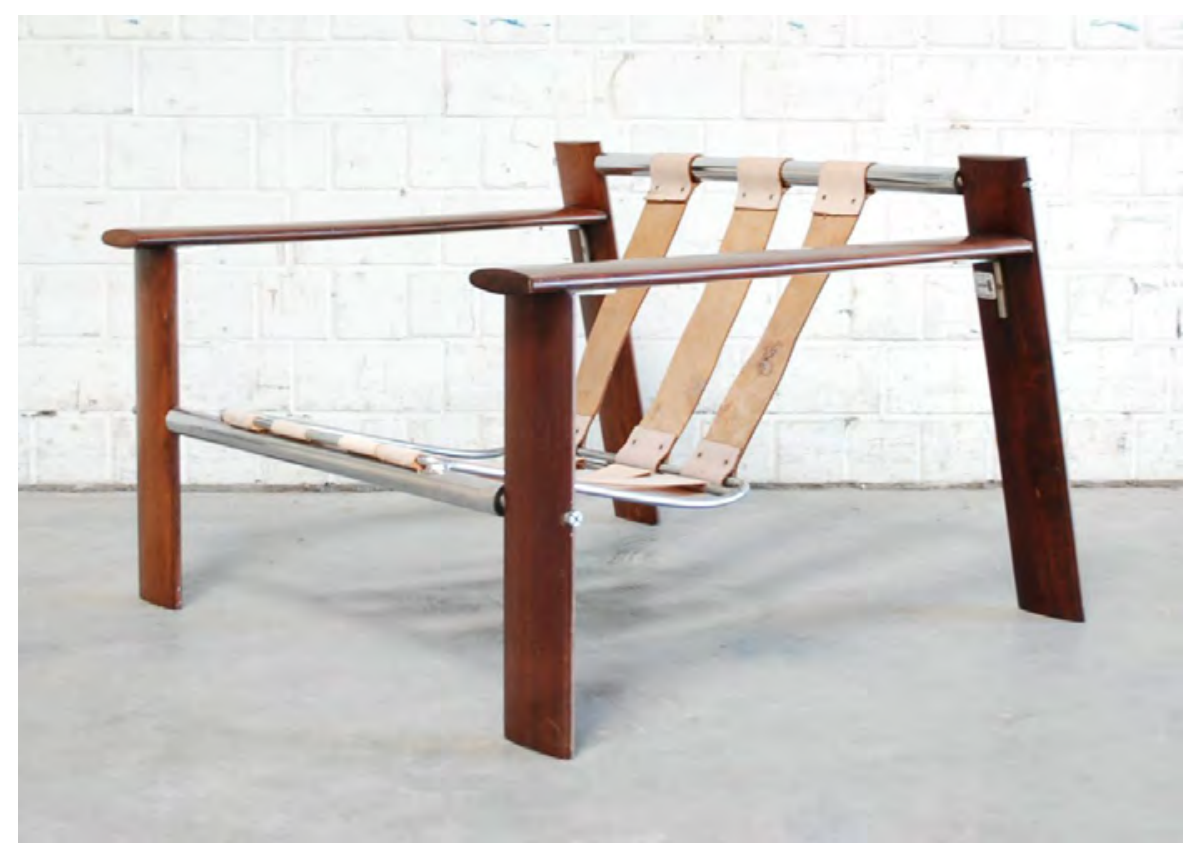


$\oplus$

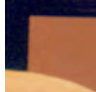

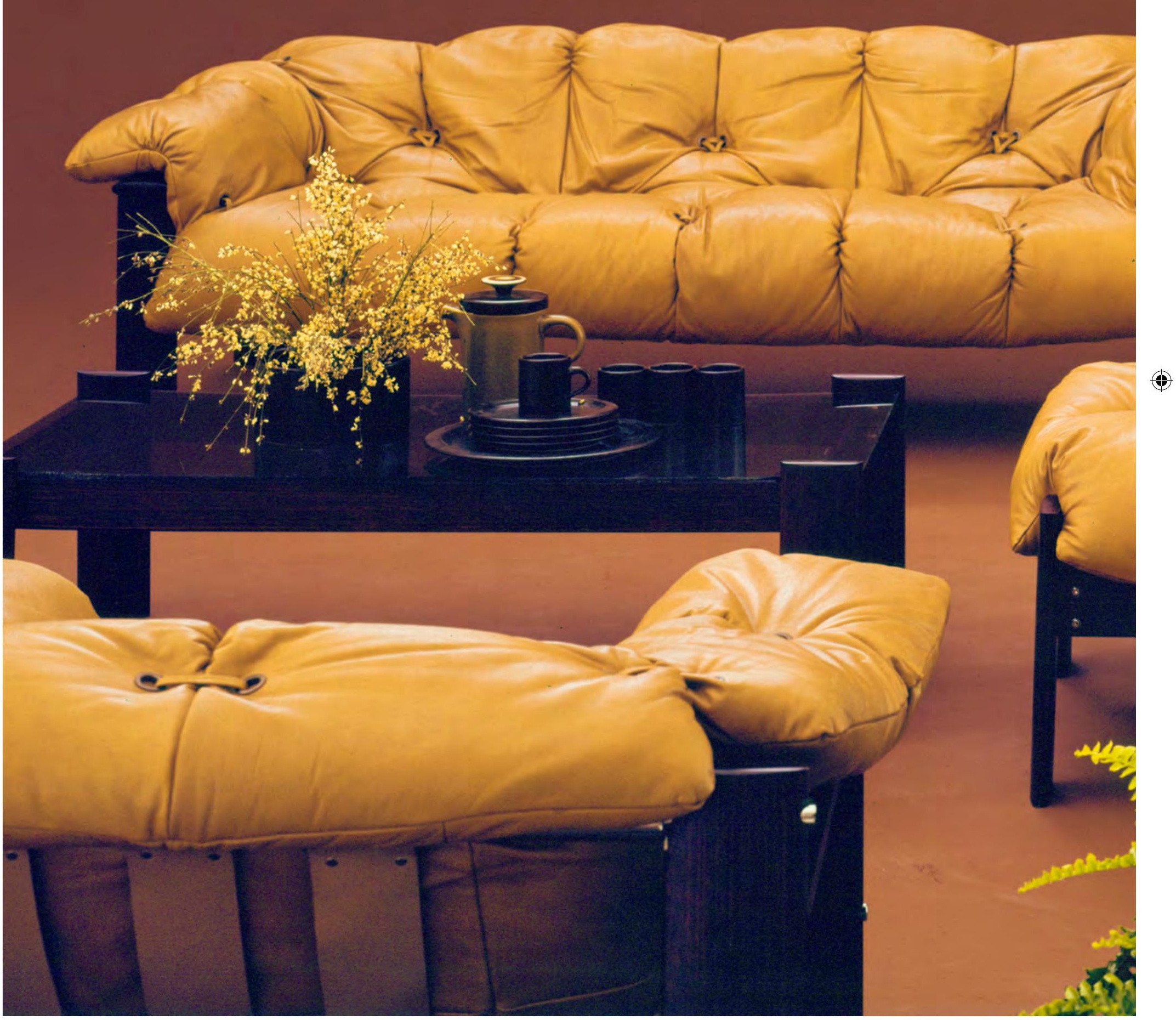

.

1.

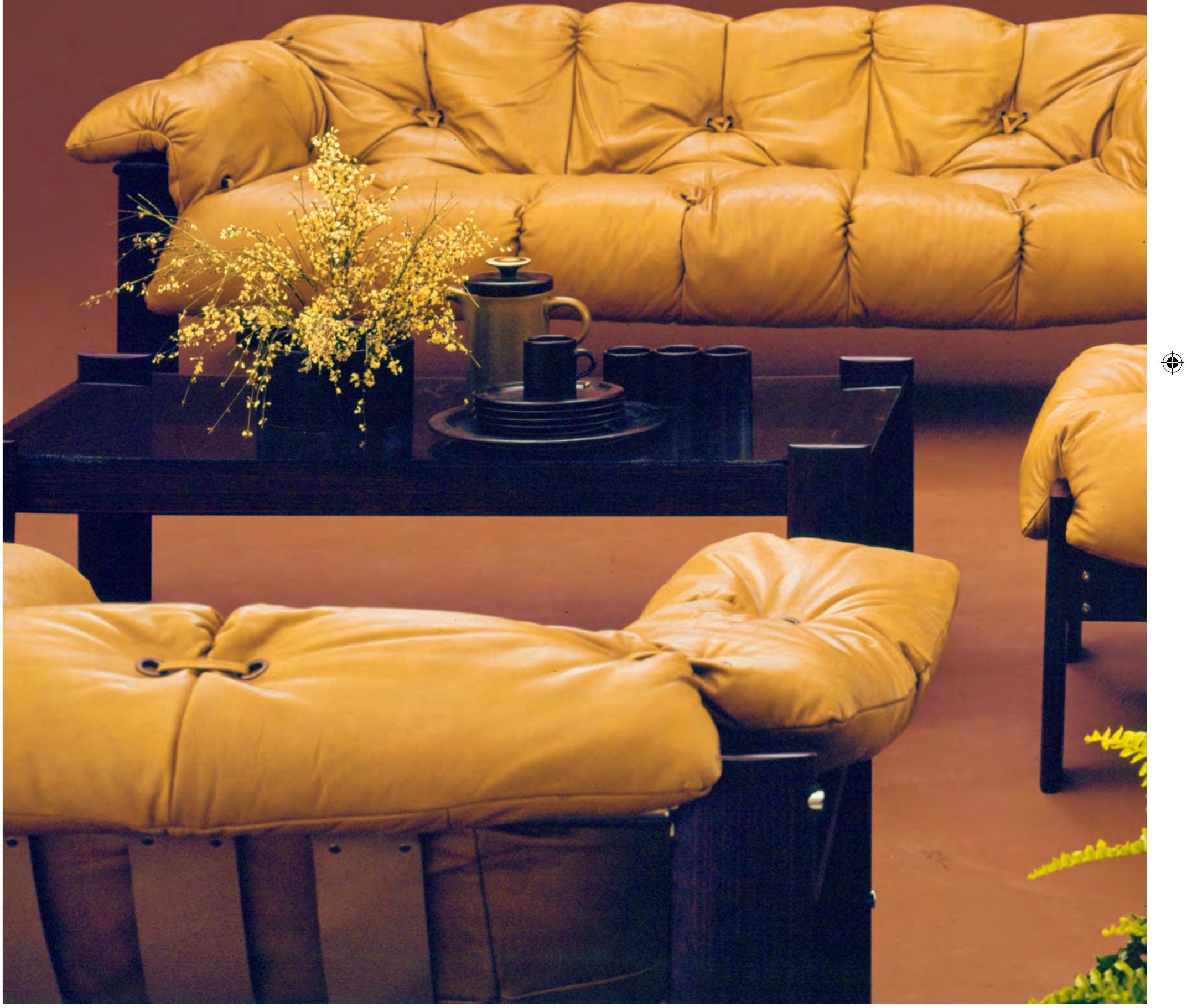

$\therefore \quad 50$

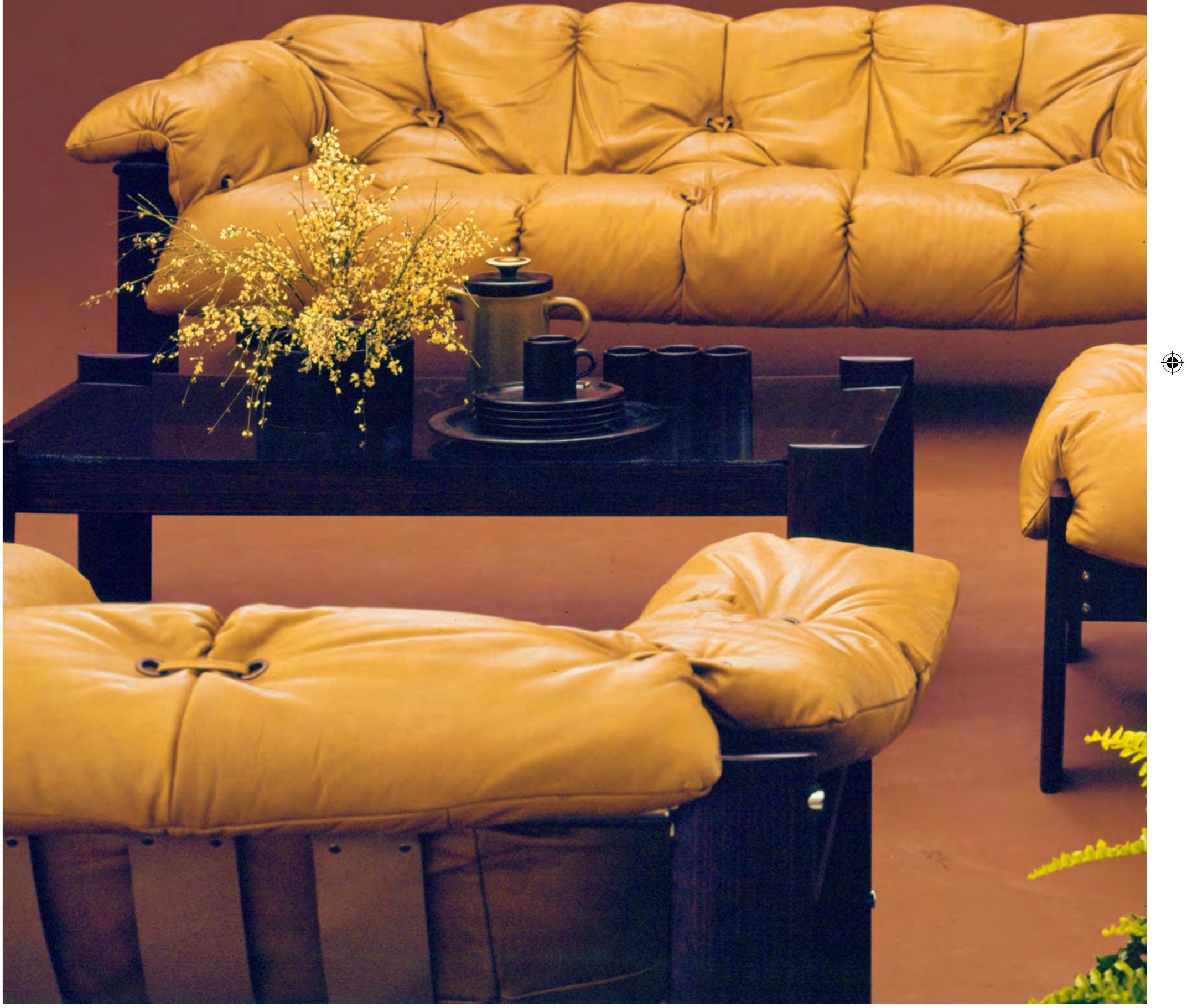


$\oplus$
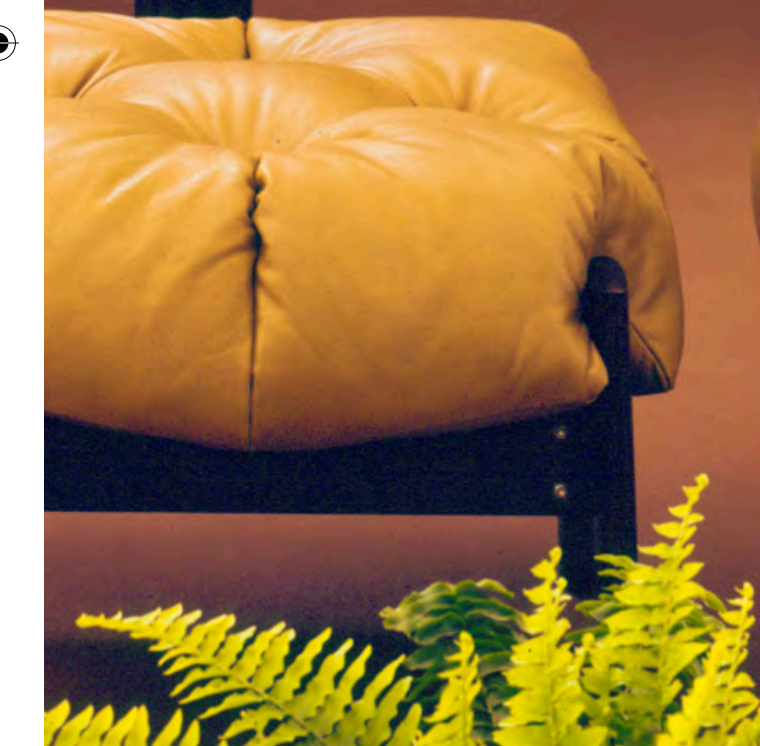

191 कि

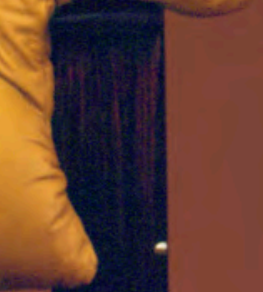




\section{MP129 (1976)}

O MP129 foi uma versão do MP131, também pensado para a exportação e mercado de luxo. A diferença entre as duas linhas se encontra no assento. Nesta variação, Percival substitui o pesado corpo em concha por uma onda de espuma injetada, com revestimento em couro capitoné. Os botões são de osso na cor clara. Mesas laterais e de centro permanecem inalteradas.

O MP129 foi adaptado ao mercado nacional, recebendo versão popular em madeira de perfil retangular, não ovalada, laqueada em cores. Na foto do stand montado para a Feira de Utilidades Domésticas de 1974, podemos ver um exemplar em branco, estofado em courino caramelo.

Conjunto MP129 ambientado com poltrona, sofá e mesas central e de apoio.

Fonte: arquivo do designer

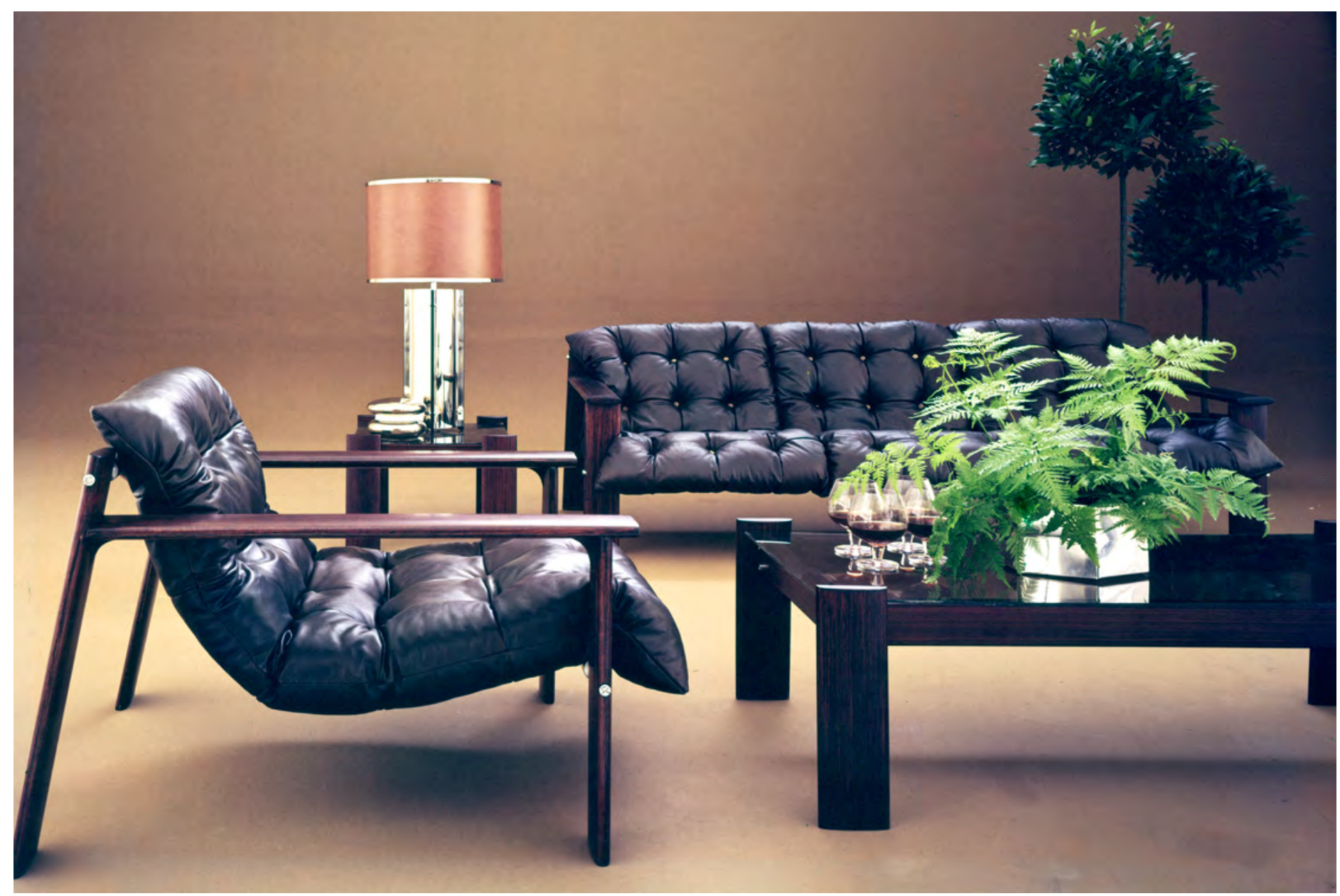


Conjunto MP127 ambientado com poltrona, sofá e mesas central e de apoio.

Fonte: arquivo do designer

\section{MP127}

Os perfis de madeira ovalada foram usados também no conjunto MP127, embora de outra maneira dentro do percurso de projeto de Lafer. Unidos em meia esquadria, formam um quadro lateral que suporta um estofado sólido e único. Os perfis metálicos redondos continuam fazendo a união entre as partes, enquanto as tiras que partem do estofado, dando a volta nos braços em quadro, dão a impressão de que o corpo é suspenso por estes - recurso meramente estético.

Os móveis MP127 apresentam um desenho que fica no meio do caminho entre as linhas apresentadas anteriormente e as que apresentaremos a seguir.

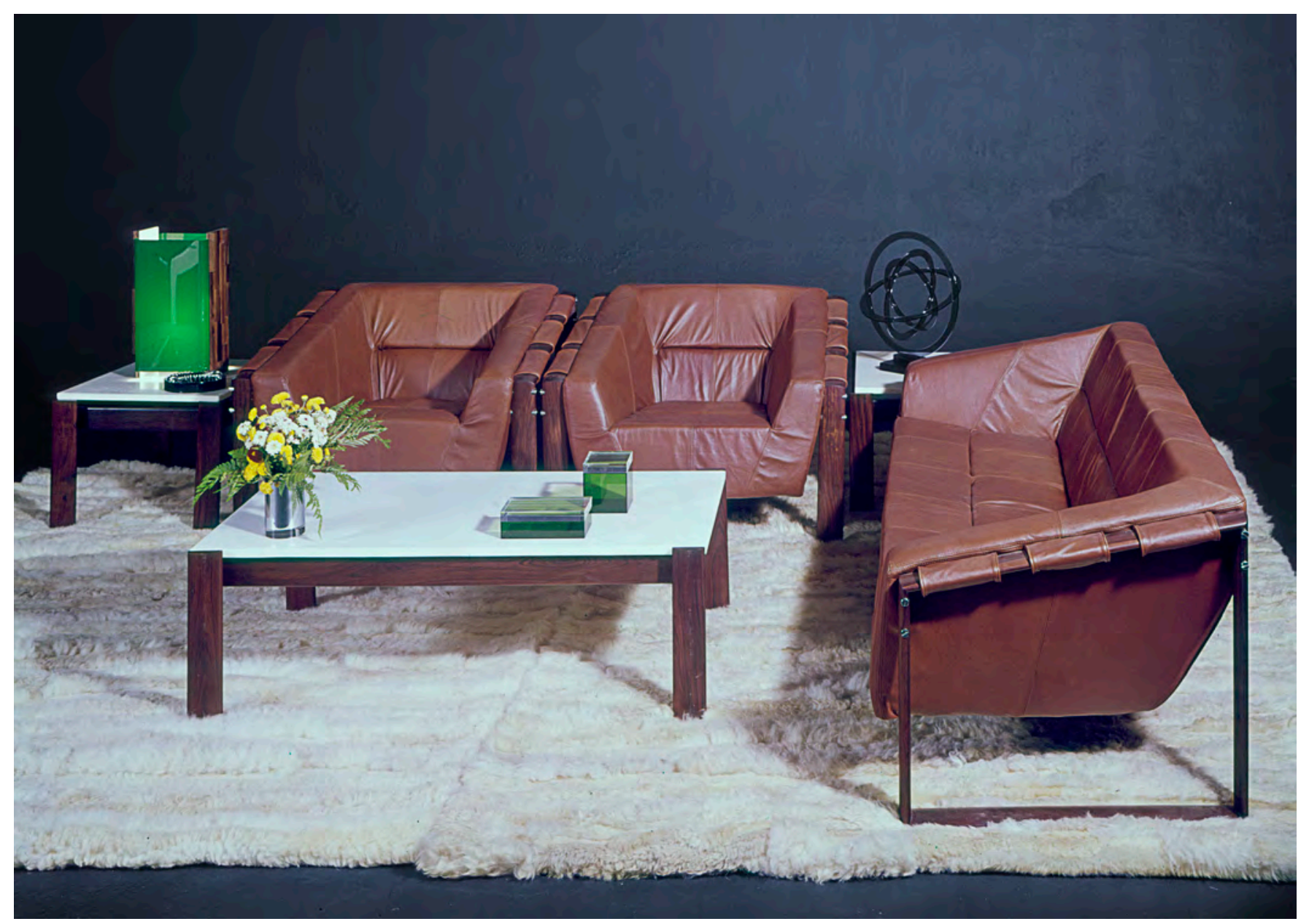




\section{MP61 (1972) - A CONCHA}

A linha do MP61 inaugura uma série de novas experiências que estavam intimamente ligadas ao estudo e investimento em tecnologia de fabricação que utilizavam a fibra de vidro como matéria. Durante os anos 60 , houve um grande modismo do uso do material por designers do mundo todo. ${ }^{32}$ A era espacial influenciou a moda, e o desenho de mobiliário seguiu essa tendência, tendo que responder a uma demanda de mercado.

Percival já empregava o uso da fibra de vidro desde que começou a trabalhar com espuma injetada. Os moldes eram produzidos em fibra, para depois serem injetados. Vale lembrar que a empresa começou a fabricar e fornecer os famosos orelhões para a Companhia Telefônica Brasileira (CTB) no mesmo ano de criação da MP61. O desenho ovóide, também fruto de inspirações espaciais, influenciou, sem dúvida, o designer a criar segundo alguns ditames de forma. Isso fica evidente nas linhas seguintes. Este conjunto inaugura uma chave de desenho em Percival Lafer.

A concha foi, dessa forma, uma solução de assento recorrente ${ }^{33}$. As poltronas mais expressivas e estilisticamente significativas para a definição da obra de Lafer seguiram esse modelo, propondo um corpo sólido, no qual os pés e outros elementos acoplam-se. O estofamento deixa de ser um elemento solto e passa a fazer parte da própria estrutura

32 Quando dizemos "mundo todo", nos referimos aos países que encabeçaram a produção material ocidental da metade do século 20 para frente, calcando o que viria a ser internacionalmente conhecido como significado e prática do "design". Dos anos 1950 ao final dos 1970, experiências muito próximas como a fibra de vidro foram desenvolvidas por Eeron Saarinen, Warre Platner e o casal Eames nos E.U.A; Marc Held, na França; Arne Jacobsen e Werner Panton; na Dinamarca; e Cesare Casati, na Itália. No Brasil, Percival Lafer foi um dos entusiastas da fibra, mesmo que em muitas de suas peças o uso não pareça evidente. Não há como traçar precisamente o grau de influência entre o desenho internacional e o que se desenvolvia no Brasil, mas sem dúvida o designer conhecia o mercado externo, já que exportava, e se inspirou nele.

33 Recorrente não apenas nos produtos de Percival Lafer. Praticamente a totalidade dos designers exploraram a forma da concha de alguma maneira. A poltrona guarda em si o valor desse espaço característico e simbólico, o que pode gerar um estudo belíssimo a cerca de sua evolução no curso da história. Restringindo-nos apenas ao âmbito da forma, podemos citar as experiências nacionais: os desenhos da poltrona Bowl, de Lina Bo; muitas poltronas de Jorge Zalzsupin, que usou a técnica do compensado curvado e também da fibra de vidro (poltrona paulistana, sênior, presidencial etc.); a releitura das cadeiras de área, com estrutura metálica redonda com assentos e encostos em "macarrão" vinílico, realizadas por Zanine Caldas, dentre outros. (N.d.A.) 
Poltronas MP 61.

Fonte: arquivo

do designer
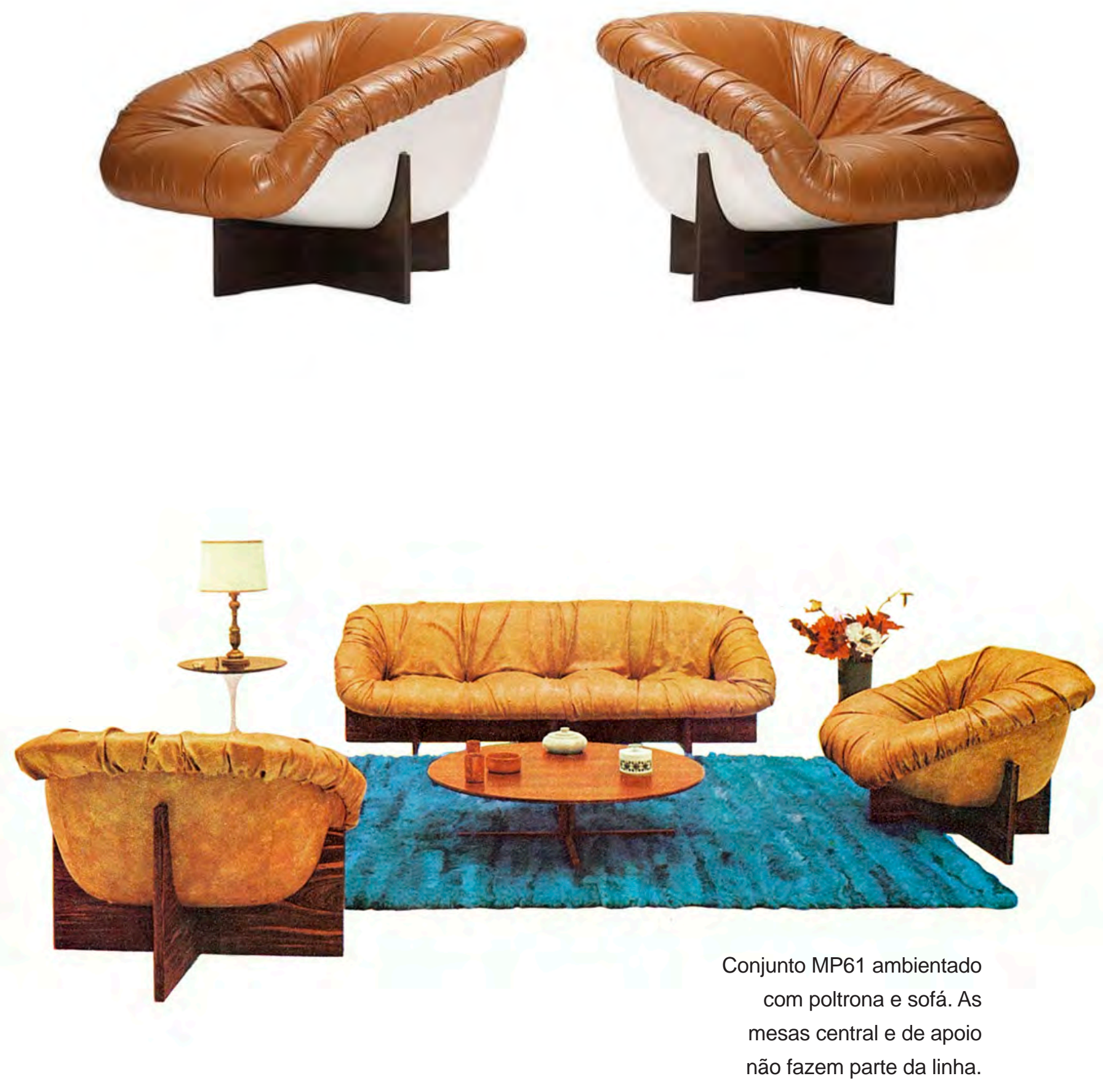

Fonte: arquivo do designer 
do móvel. A solução combinada de estofado e estrutura induzem a um certo tipo de corporeidade do usuário. A concha propõe uma forma de relação específica com o corpo, quase que atávica, na medida em que se apresenta enquanto continente absoluto, de encaixe ao corpo que recebe, como se o molde da forma fosse 0 ato de sentar. Bachelard, fala lindamente sobre a concha, abrindo possibilidades de leitura poética sobre o mobiliário, propondo o contrário da significância esperada:

"O ser que se esconde, o ser que 'entra na concha', prepara 'uma saída'. Isso é verdade em toda escala de metáforas, desde a ressurreição de um ser enterrado até a expressão súbita de um homem taciturno durante muito tempo. Permanecendo ainda no centro da imagem que estudamos, parece que, ao conservar-se na imobilidade de sua concha, o ser prepara explosões temporais do ser, turbilhões do ser. As evasões mais dinâmicas são feitas a partir do ser reprimido e não na mole preguiça do ser preguiçoso que não deseja senão espreguiçar-se em outros lugares.

\section{$[\cdots]$}

Outras vezes ainda, a imagem ganha sua força por efeito de um isomorfismo de todos os espaços do descanso. Então, todas as concavidades acolhedoras são conchas. [...] O homem, o animal, a semente, todos encontram o descanso máximo na concha. Os valores do descanso comandam todas essas imagens. ${ }^{34}$

vO sofá e poltronas MP61 são compostos de um berço em forma de concha, produzido em fibra de vidro e revestidas em camurça. Esta base recebe uma "contra-concha", em espuma injetada, com acabamento em couro na mesma cor da camurça. Os revestimentos diferentes propõem um direito e um avesso visual da poltrona. Os pés são formados por placas de madeira revestida em pau ferro, dispostas em " $x$ ", formando uma base de encaixe preciso à forma. $A$ concha contém rebaixos para receber a estrutura do pé de forma precisa. O conjunto de mesas é releitura de mesas Saarinen e Florence Knoll, e não foram produzidas pela Lafer. 


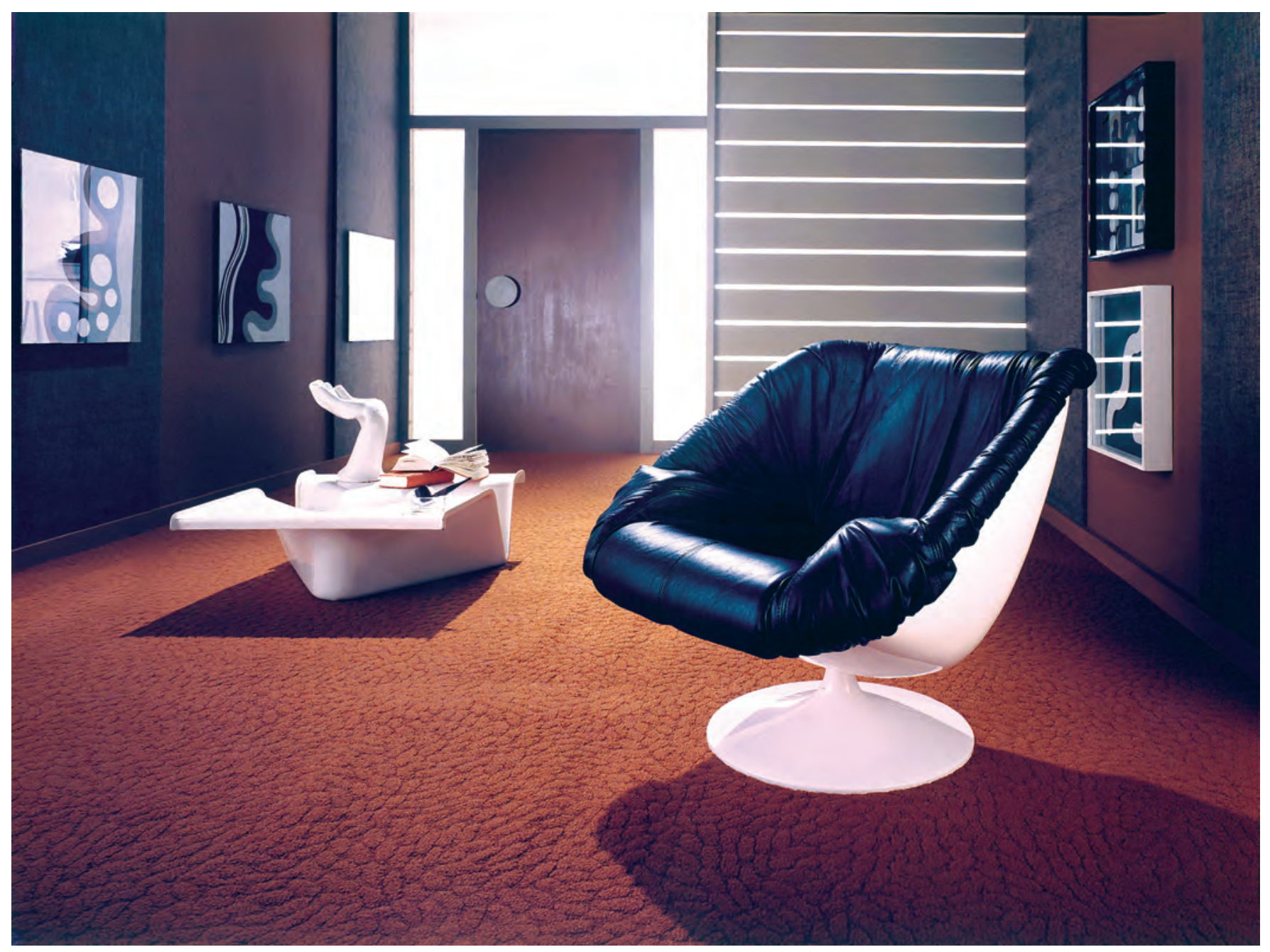

Poltrona MP 71, ambientada.

\section{MP71 (1973)}

Fonte: arquivo do designer

A poltrona MP71 é avulsa e segue o mesmo princípio do conjunto de sala MP61, com algumas alterações de desenho na concha de fibra de vidro e na espuma. Os braços são acoplados ao corpo, por meio de duas reentrâncias internas, nas laterais. O conjunto é revestido em couro, enquanto a estrutura branca, seguindo uma solução comum na época, é aparente. A poltrona foi desenhada em forma de tulipa, e o pé giratório é acoplado ao corpo em concordância de curvas, o que dá continuidade formal ao conjunto.

A banqueta em forma de cogumelo, também giratória, era produzida a partir do mesmo princípio, e estruturalmente montada como um "botão encapado". 


\section{MP81 (1975)}

Consideramos esse conjunto o mais representativo do estilo desenvolvido por Percival. As soluções formais e estruturais são inovadoras e o resultado simbólico de seu desenho está em consonância com o que podemos considerar um desenho nacional. O corpo massivo se sustenta por pés em forma de toras, pedaços de paus soltos, burdunas indígenas. Há uma dimensão autóctone, do âmbito da bricolagem, mesmo que apenas aparente, na concepção desse conjunto. As peças parecem estar unidas por um jogo informe de forças e pesos. O corpo massivo em couro parece sobrecarregar os pés, que em inclinação criam a impressão de equilíbrio instável das peças, recurso já explorado anteriormente. Sem dúvida, uma reverberação da Poltrona Mole de Sérgio Rodrigues, mas não deixa de ser original e inusitada.

Todos os componentes usados são produzidos industrialmente. Aqui encontramos expressamente a intenção de Lafer de criar móveis industrializados com aparência artesanal. Os perfis escultóricos do pés e mesmo os botões lapidados em jatobá maciço eram cortados e torneados mecanicamente.

Houveram duas versões estruturais. A primeira utilizava uma concha de fibra de vidro revestida sobre a qual os pés eram aparafusados. Com o tempo, os corpos das poltronas passaram a ser fabricados em espuma injetada. A concha passou a ser utilizada apenas como forma, sendo substituída por uma estrutura metálica em " $x$ " embutida na espuma no momento de sua injeção. $O$ conjunto do estofado era revestido em couro, e o repuxo formava um capitoné que reforçava o jogo dinâmico do equilíbrio das formas. A impressão é que se havia partido de uma grande massa, que repuxada, formava o assento.

A mesa de centro seguia o mesmo princípio e recebia revestimento do quadro principal com espuma laminada leve, apenas para lhe conferir um "fofo". O tampo era revestido em couro mais escuro.

A linha foi enormemente exportada e também conseguiu importante reverberação no mercado nacional, guiando a criação e produção de várias outras linhas apresentadas na sequência. 


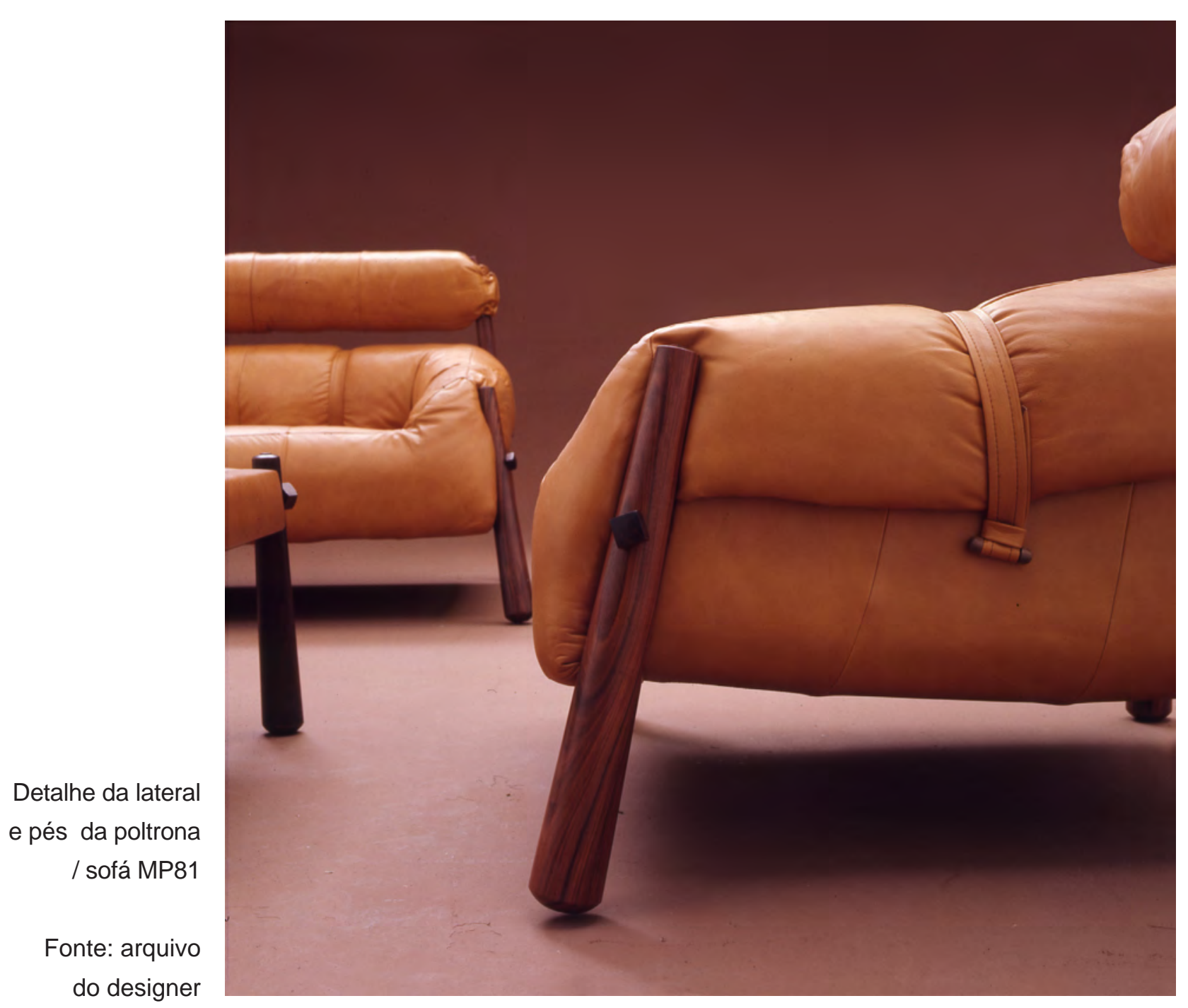

$\oplus$

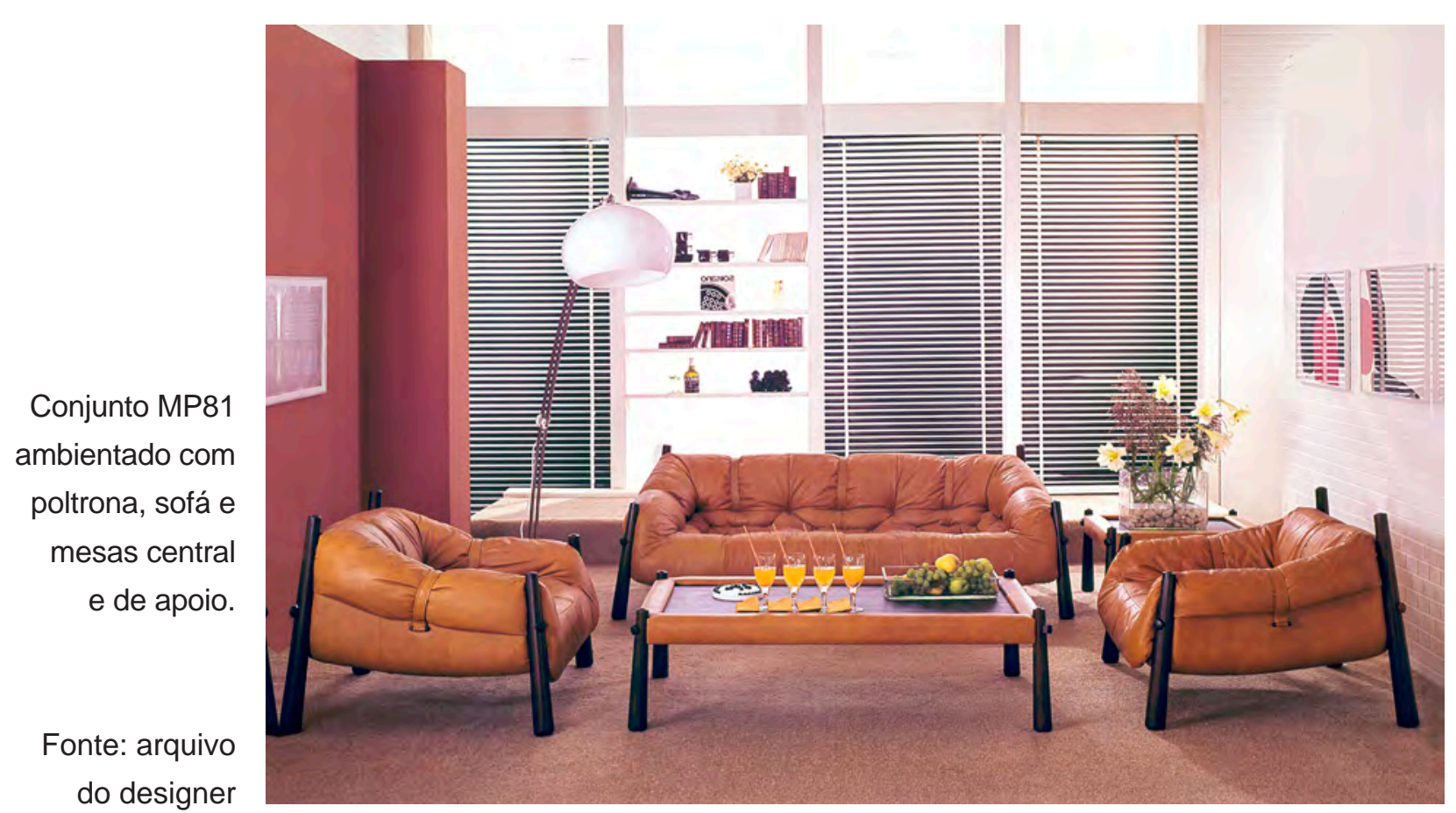



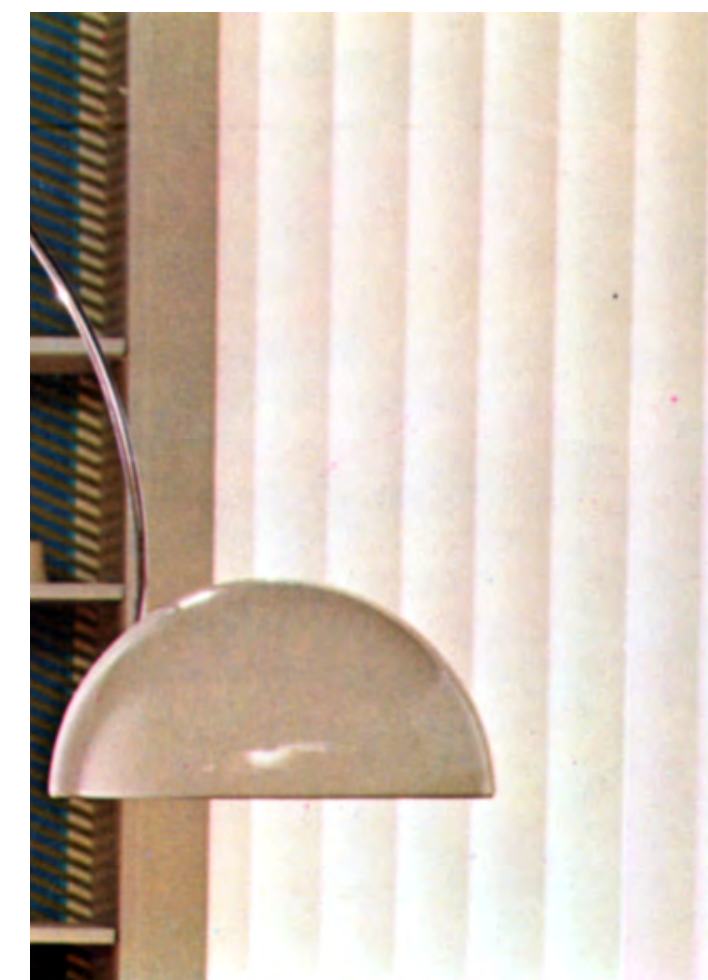

(4)
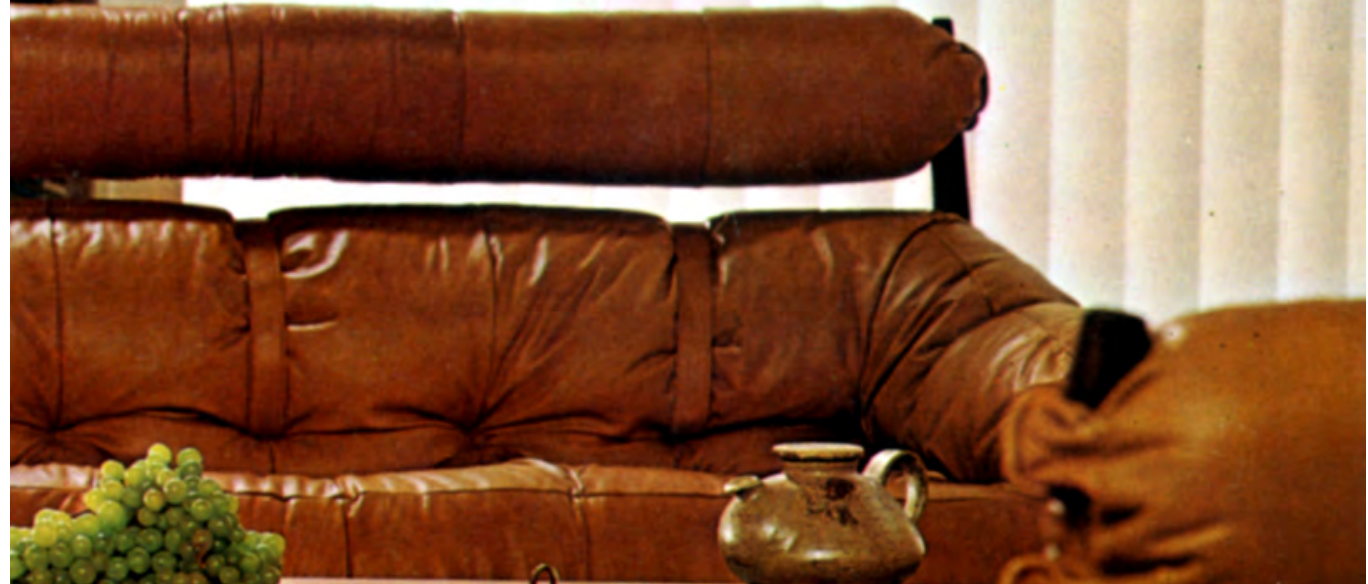

Conjunto MP81

ambientado com

poltrona, sofá e

mesas central

e de apoio.

Fonte: arquivo

do designer 


\section{MP111 (1975)}

A solução estrutural do conjunto de sala MP111 segue os mesmos princípios de produção adotados no MP81. O resultado formal, embora dentro da mesma linguagem, é completamente outro.

O corpo do móvel em espuma injetada e o sistema de fixação, por meio de estrutura metálica, embutida seguem os mesmos. No entanto, a forma do estofamento mudou de desenho, agora com linhas mais quadradas e com um braço contínuo em forma de asa. A ideia era produzir uma poltrona que parecesse suspensa como uma rede presa em estacas. As amarrações presentes na ponta do revestimento em couro, parecem sustentar o conjunto de forma despojada. As bolas, dispostas nas pontas do cordame em couro de madeira, simulam paradas e contribuem para esse efeito.

Os pés, em perfil de madeira maciça, são compostos de duas partes unidas e aparafusadas na estrutura metálica chata do próprio estofado. A inclinação dos mesmos é invertida em relação a linha anterior, o que dá a sensação de contrapeso ao estofado massivo.

Houve especial atenção no desenho do revestimento, que apresenta subdivisões acolchoadas. Entre os gomos, o pesponto de fita de couro simula uma costura grossa.

O conjunto é composto de sofá 2/3 lugares e poltronas. A mesa, usada para ambientação, pertence a linha Woosdstick.

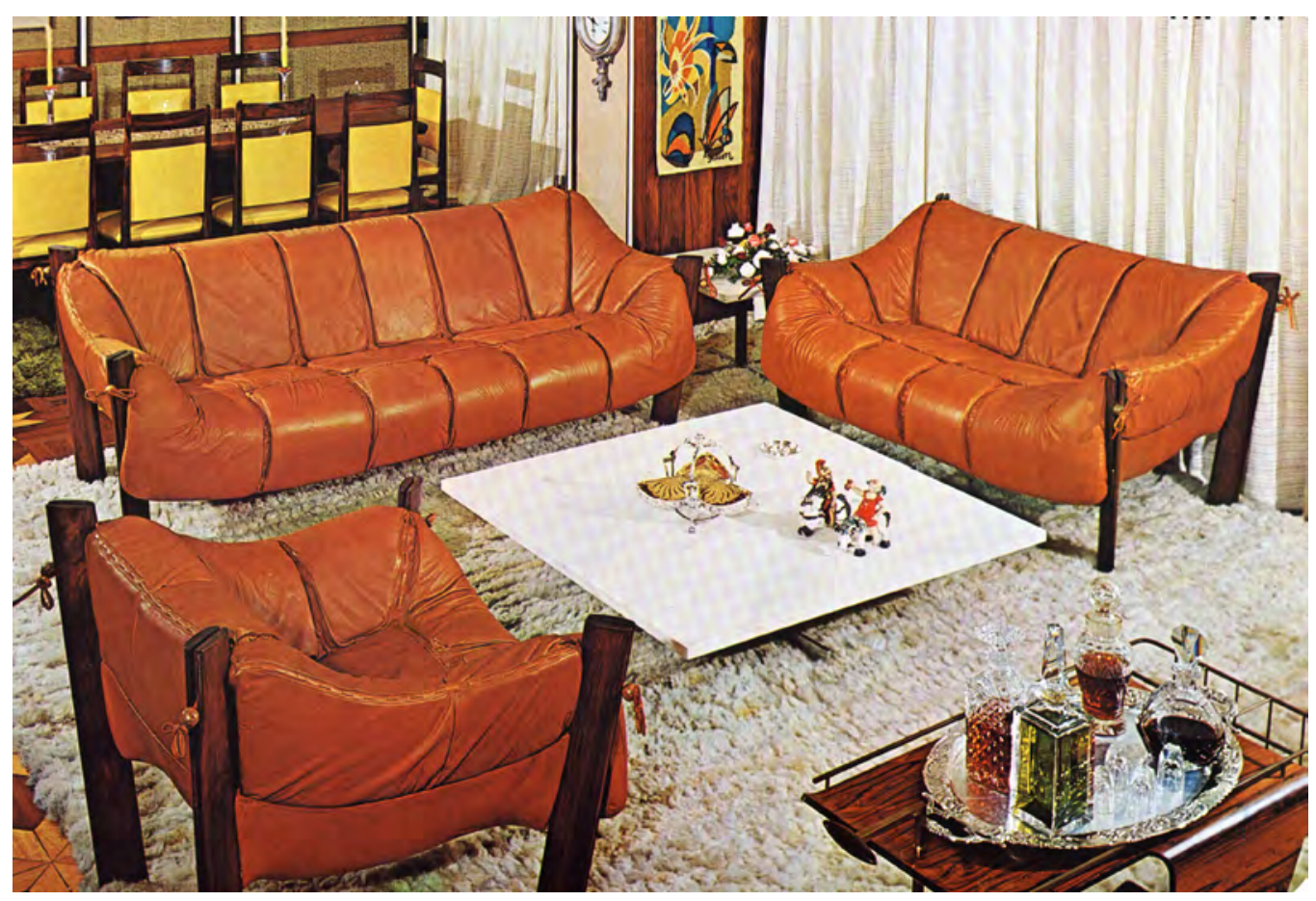

Conjunto MP111

ambientado com poltrona, sofá . As mesas central e de apoio não fazem parte da linha 

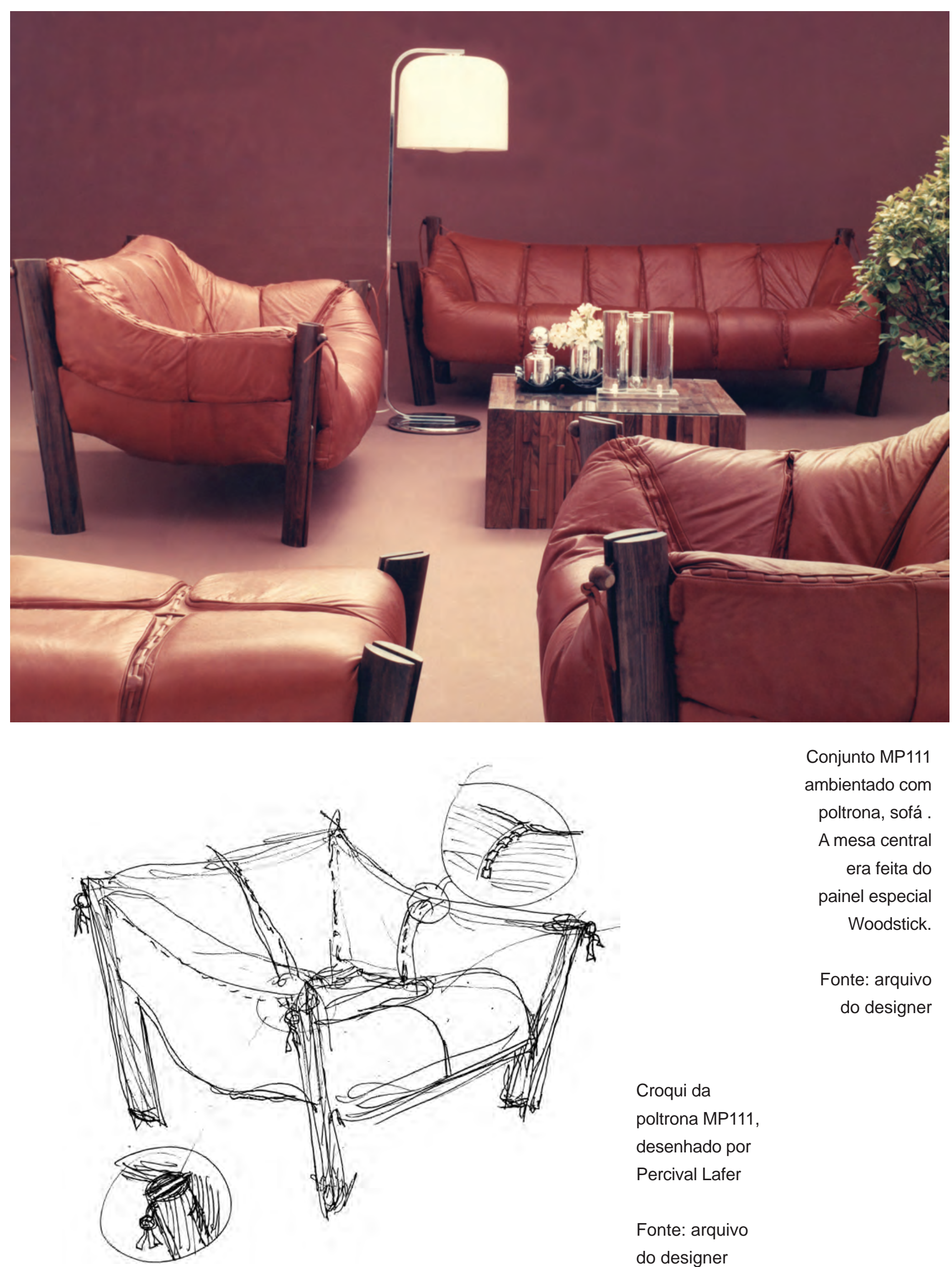

Conjunto MP111 ambientado com poltrona, sofá . A mesa central era feita do painel especial Woodstick.

Fonte: arquivo do designer

Croqui da poltrona MP111, desenhado por Percival Lafer

Fonte: arquivo do designer 


\section{MP211}

Para os móveis de sala MP211 todos os princípios anteriores foram utilizados, embora, estruturalmente, o conjunto funcione de forma um pouco diferente. Dessa vez, o corpo de estofado é livre, sendo apoiado em uma contra-concha de tela, que, por sua vez, é estruturada por um aro rígido de metal ligado aos pés. Estes, de madeira maciça, são quadripartidos e unidos por peças metálicas. As amarrações metálicas com o corpo dos móveis são únicas para cada pé, com exceção dos pés dianteiros, que recebem duas barras metálicas.

O estofamento, em espuma injetada, segue o padrão de gomos do MP111, com outras proposições de acabamento. O pespontão em couro deu lugar a uma fita aplicada de mesmo material. Os conjuntos foram quase completamente exportados e são raros no mercado de usados.

Conjunto MP211 ambientado com poltrona, sofá . A mesa central era feita do painel especial Woodstick.

Fonte: arquivo do designer

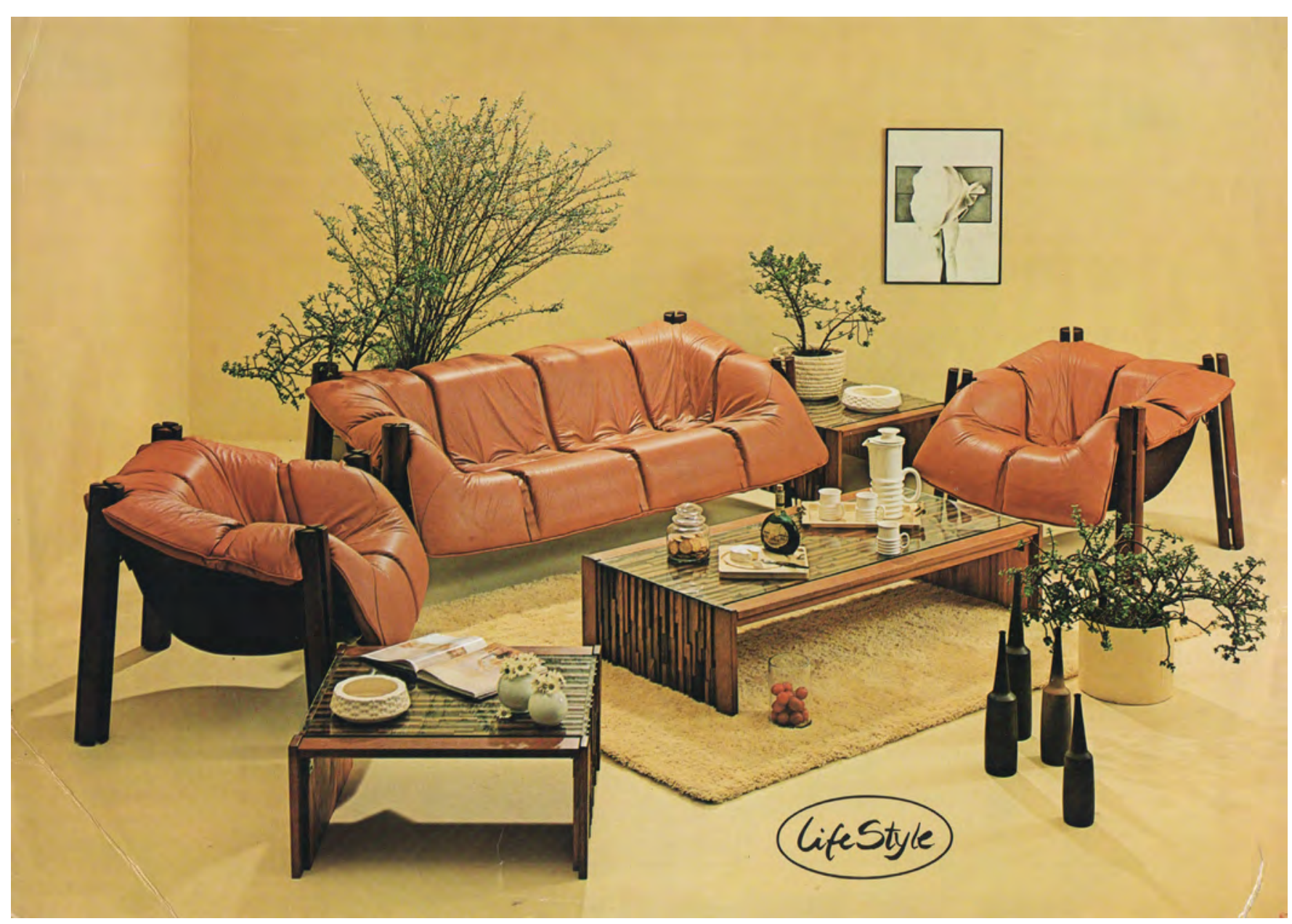




\section{MP97}

O MP97 talvez seja o conjunto mais conhecido de Percival Lafer. Foi amplamente comercializado no mercado nacional, tendo vida longa de produção e diversas reedições. Ele é representativo de uma série de outros móveis que propunham outra forma de encaixe entre a concha e a estrutura mista de madeira e metal. Os pés, ora escultóricos e localizados nas extremidades do estofado, foram transformados em quadros laterais, solução amplamente utilizada por Lafer em outras linhas de luxo e mais populares, como veremos a seguir. O conjunto do MP97 não é inaugural nesse tipo de concepção, mas sim o mais representativo. Houveram outras linhas precedentes que já apresentavam essa forma de construção, com algumas diferenças.

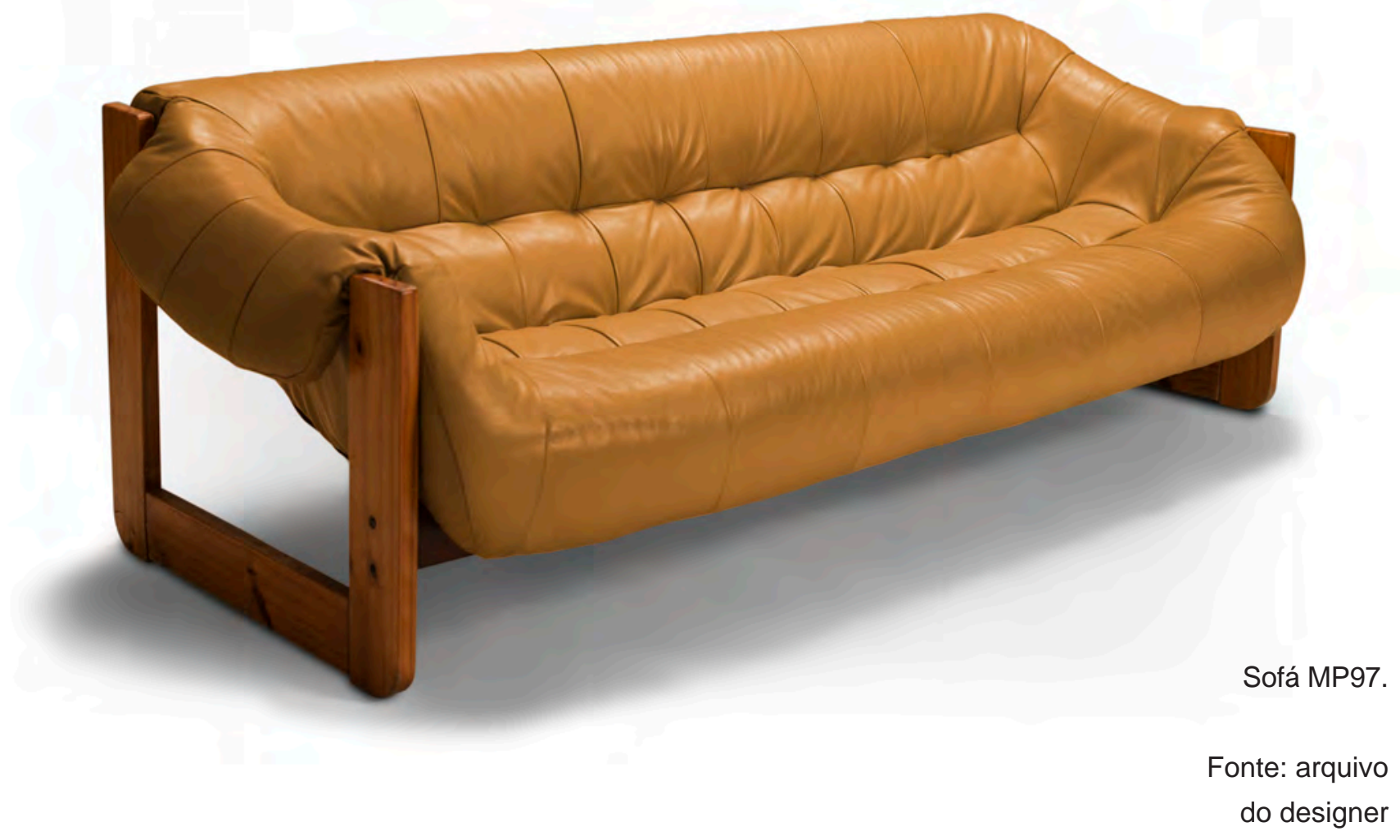


O estofado em concha é composto por peças únicas de espuma injetada, revestida de couro ou courvin capitoné. Em modelos anteriores, ele apresentou formas mais geometrizadas, enquanto no MP 97, os ângulos foram suavizados em curvas. A estrutura é composta por dois quadros abertos em "U" de madeira, com extremidades de alturas diferentes para suportar encosto e assento. A parte superior dos quadros são fechadas e unidas por um perfil metálico moldado para receber o encaixe do braço do corpo do móvel. Os quadros são unidos horizontalmente por trava de madeira, que sustentam o conjunto de percintas em cadarço de nylon, presas às travas por pequenos tarugos de madeira. Essa estrutura lateral já fora outrora produzida totalmente em madeira, utilizando, inclusive, encaixes de cavilha para junção.

O princípio de compatibilidade dos componentes continuou a ser uma tônica. Os perfis de madeira compunham tanto o conjunto de poltrona e sofá, como as mesas laterais e de centro.

O conjunto recebeu várias reedições, inclusive uma em pinus, madeira que passou a ser amplamente utilizada por Lafer, nos anos 1990.
Conjunto MP397,

reedição da linha MP97,

com estrutura de Pinus Ellioti e revestimento de couro pinhão

Conjunto de época MP97 revestido em couro alaranjado

Fonte: arquivo do designer

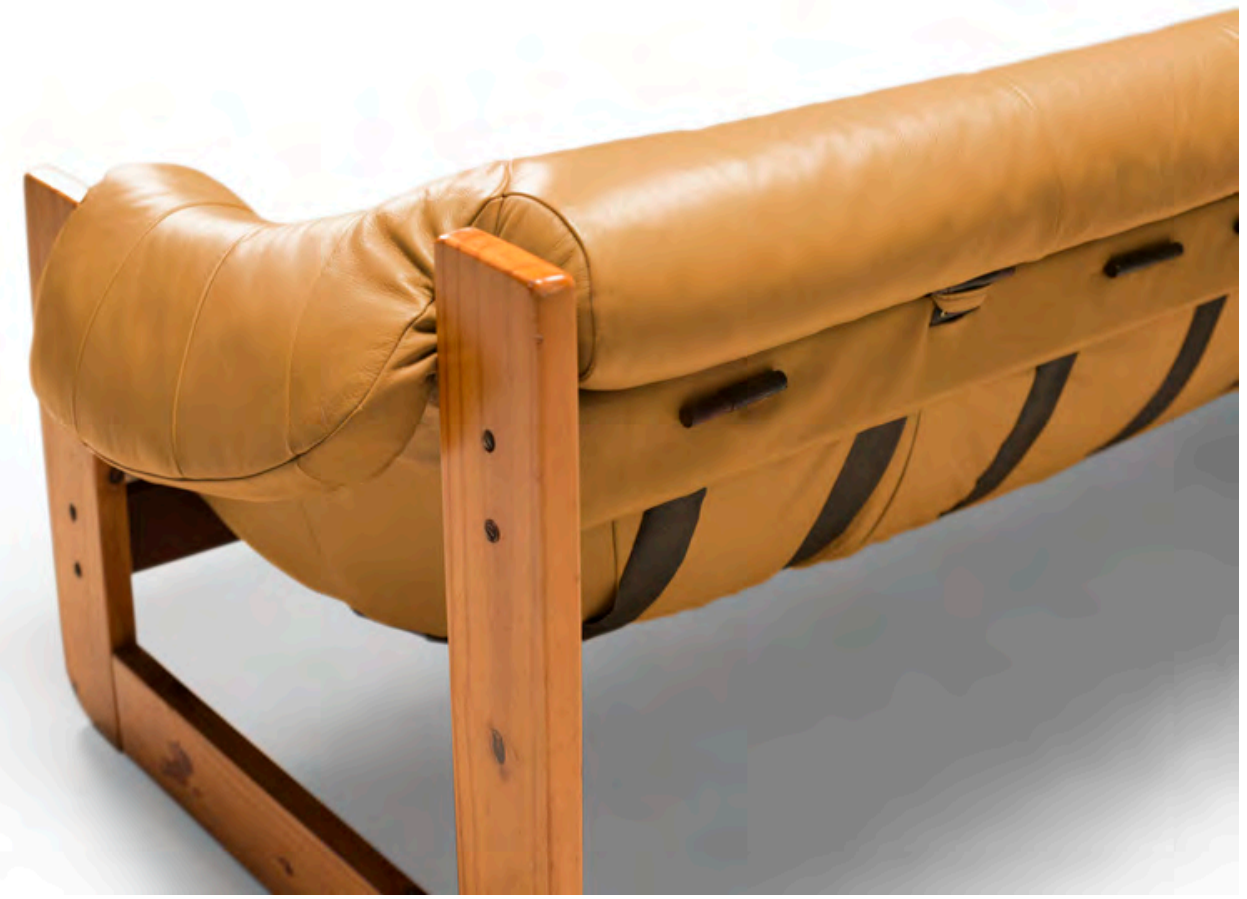

Vista Traseira do sofá MP97.

Fonte: arquivo do designer 

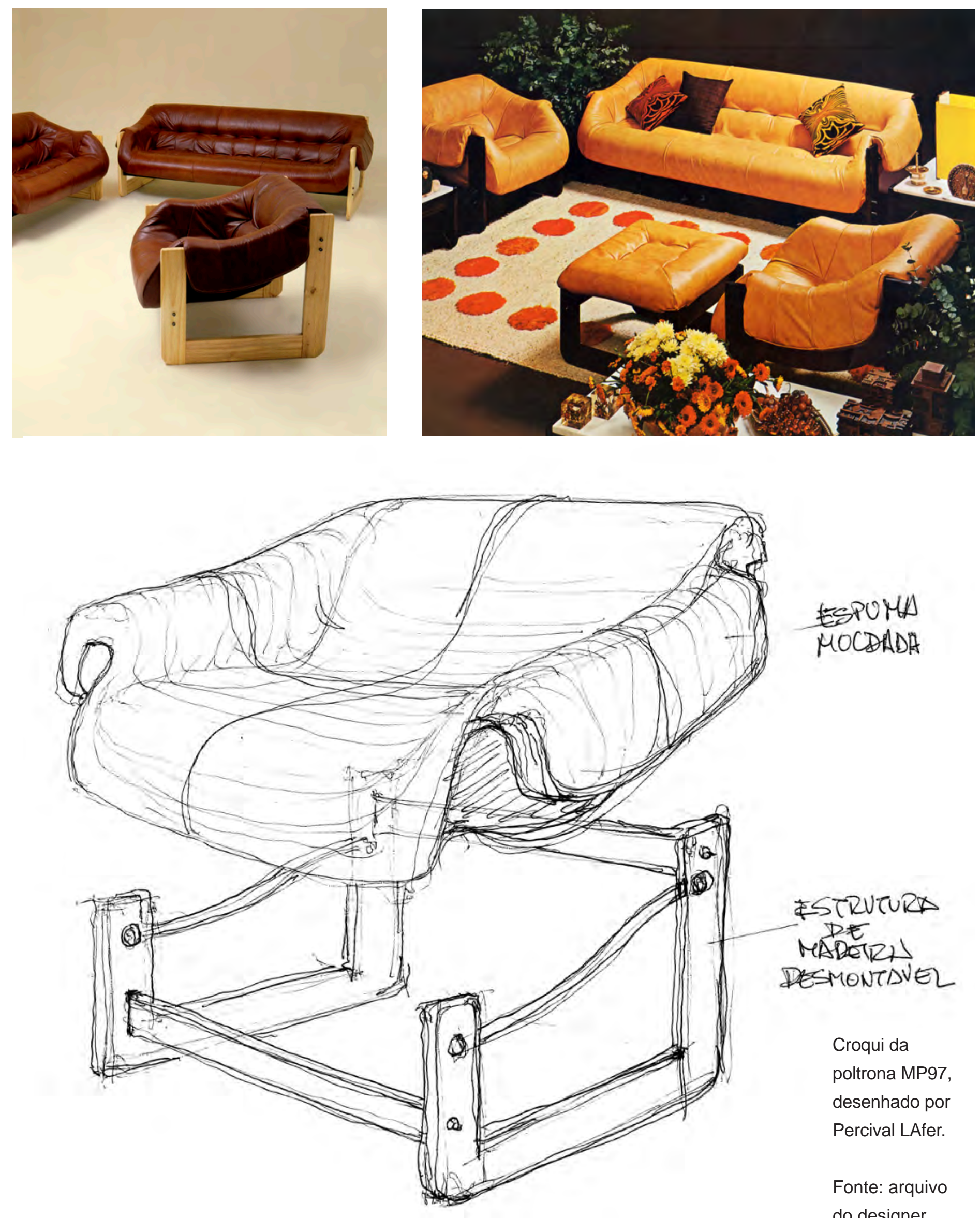

ESPOMA
MOCDADA

*strueura maderist DESMONTDVEL

Croqui da

poltrona MP97, desenhado por

Percival LAfer.

Fonte: arquivo do designer 


\section{MP79/ MP91/ MP93}

Com algumas variações, uma série de linhas foi pensada a partir da idéia de estofado que se apoioa sobre uma estrutura em forma de quadro. A base construtiva segue a concepção do conjunto MP97, e receberá variações no estofado e em alguns elementos de junção, como por exemplo cavilhas, parafusos e outros. Há ainda algumas pequenas variações de revestimento, mas aparentemente o produto eraera o mesmo.

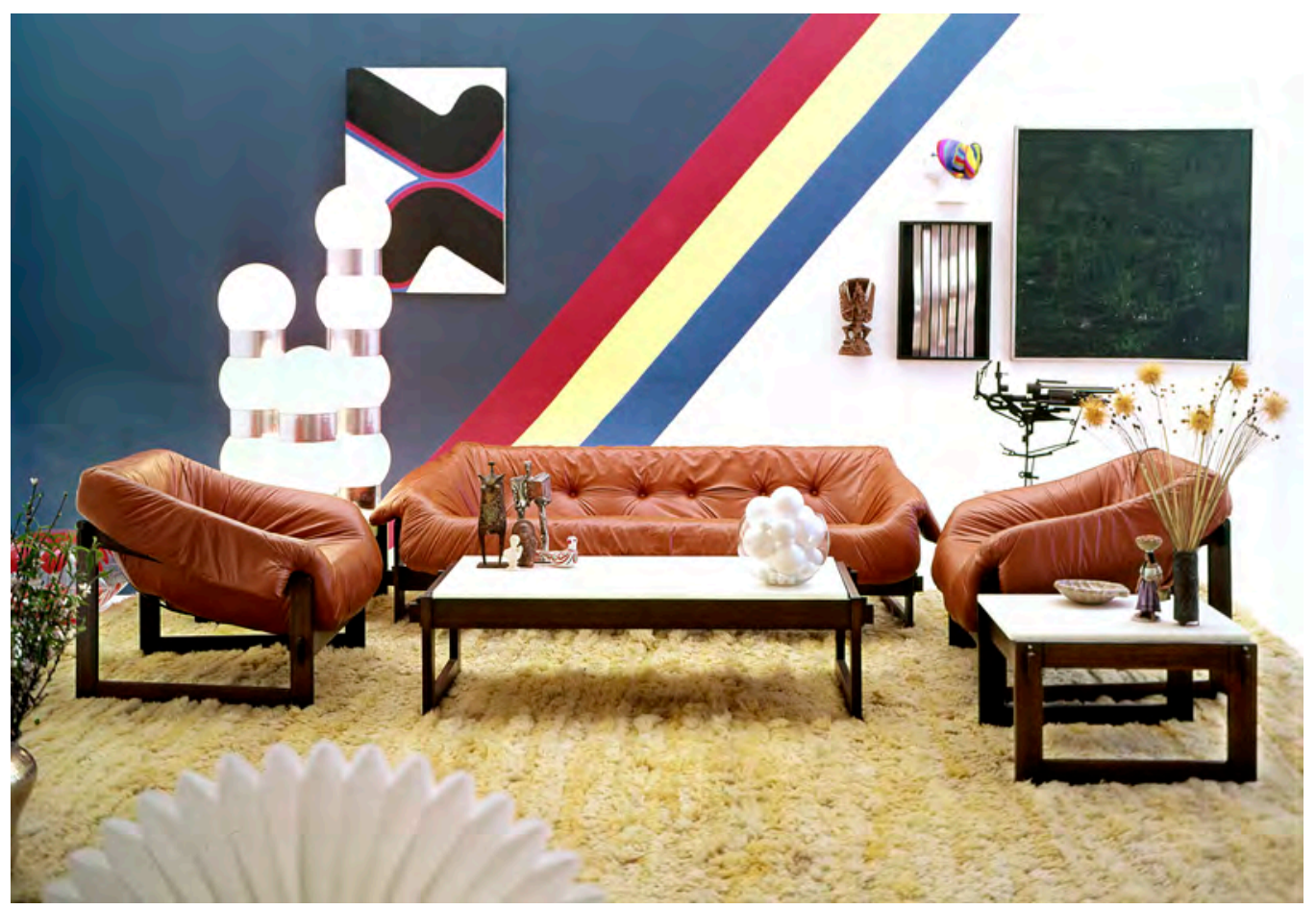

Em sentido antihorário de cima para baixo, conjuntos MP79, MP91 (em camurça), MP93 (em couro preto)

Fonte: arquivo do designer
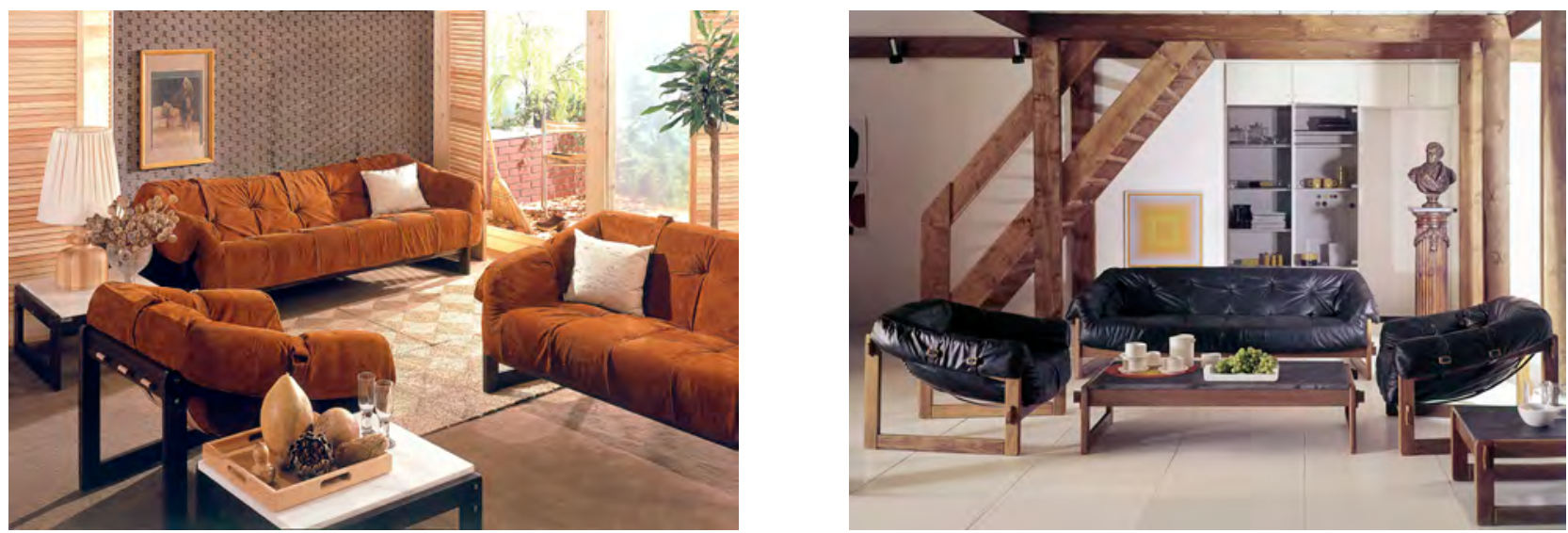
MP 133

Conjunto MP133 ambientado com poltrona, sofá . A mesa central era feita do painel especial Woodstick.

Fonte: arquivo do designer
O conjunto surgiu do desenho da poltrona. O quadro lateral foi inteligentemente invertido para se conseguir um pé que deixasse a poltrona em balanço. O estofado em espuma injetada revestida de couro pousa sobre percintas que se apoiam em um largo tarugo traseiro em madeira maciça, de forma cilíndrica. O MP133, embora tenha sido pouco produzido, é bastante representativo dentro da obra de Percival Lafer, e revela a forma de pensar o projeto do designer: os componentes produzidos em série eram aproveitados ao máximo, gerando assim declinações de desenhos variados, a partir de uma única solução.

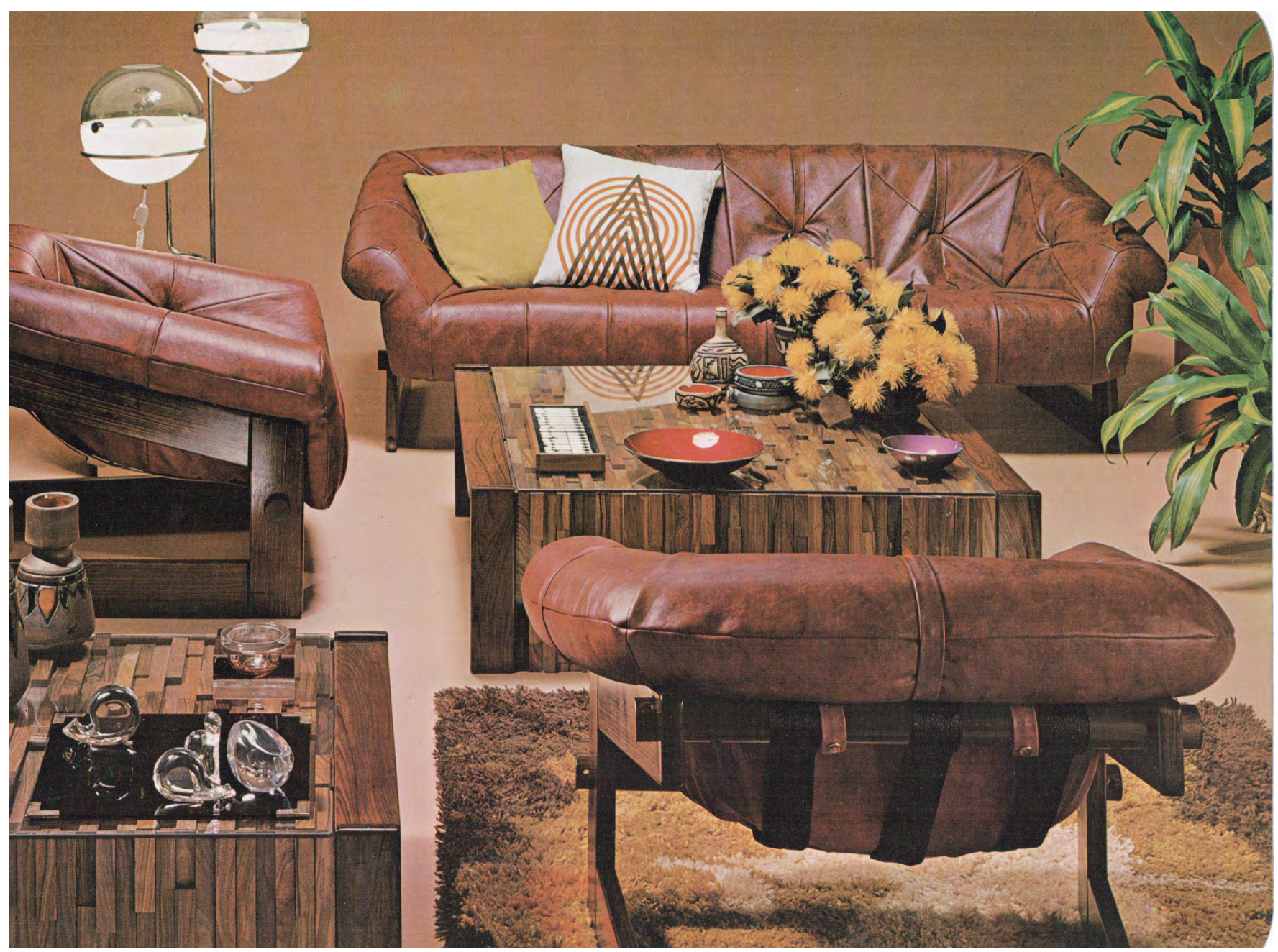




\section{MP101/ 139e o móvel espacial - 1974}

Seguindo a tendência dos móveis que misturavam o fetiche pela era espacial e a experiência extraordinária do uso de drogas alucinógenas (que propuseram um novo tipo de comportamento e relação com a experiência sensível), Percival produziu uma série de linhas de mobiliário com essa estética. O uso da fibra de vidro branca aparente, do acrílico colorido e transparente, da lycra e de novos tecidos sintéticos de cores extraordinárias, além da opção pelas formas orgânicas, contínuas e lisas (claramente um reflexo da imagem causada pelo desenho das aeronaves

Conjunto de e foguetes e das viagens de LSD e outras drogas), influenciaram Percival a criar uma série de móveis nessa chave.

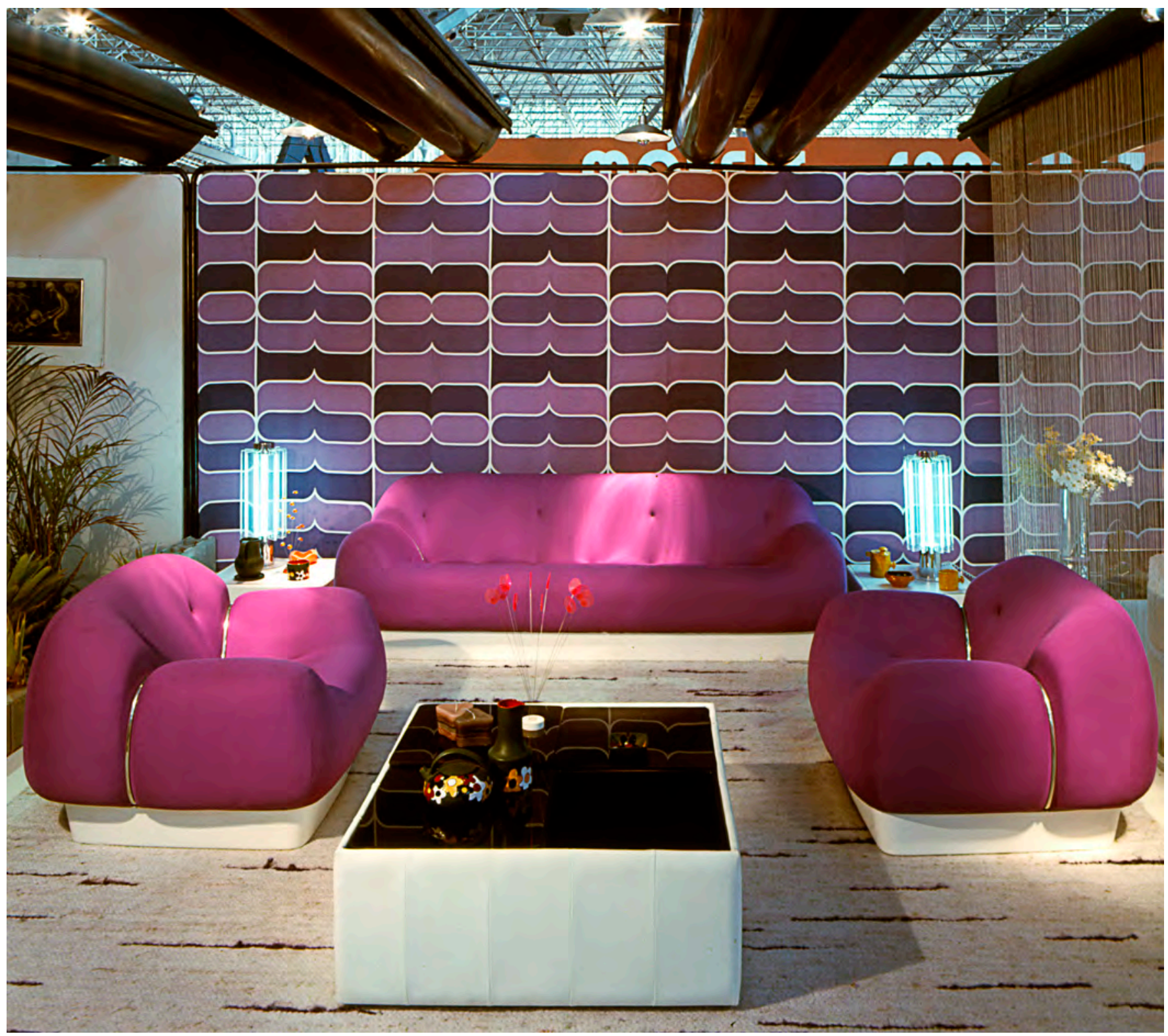


O MP101 seguiu o estilo introduzido pelos móveis italianos de Mario Bellini e Tobias Scarpa, dos anos 1970, em que perfis e tiras metálicas pareciam comprimir o estofado dando-Ihe forma. Pierre Paulin, na França, também traçou experiências parecidas. Nesse conjunto, uma banda metálica une o conjunto do estofado moldado à base de fibra, aparentemente comprimindo o corpo das peças, conferindo-lhes, assim, uma aparência "mole".

Os conjuntos apresentado a seguir seguem os mesmo princípios formais e conceituais. As formas e componentes eram adaptados dentro da cadeira produtiva, diminuindo o número de processos envolvidos. Uma única forma produzia diversos móveis - apenas com pequenas alterações na matriz. Nessa mesma época, a pesquisa e desenvolvimento de soluções modulares, dentro de uma perspectiva de adaptabilidade ao espaço e unitarização da venda, foram aprofundados.

\section{MP87}

A poltrona avulsa MP87 apresenta uma solução bem singular. Apresenta estrutura metálica sobre a qual é tencionada uma rede. Essa base recebe um drops de espuma injetada revestida de couro ou tecido. $O$ desenho fica entre a poltrona e o puff. Embora o estofado tenha aparencia mole, é bastante rijo, já que é composto de espuma injetada.

Conjunto de poltronas MP87

Fonte: arquivo do designer

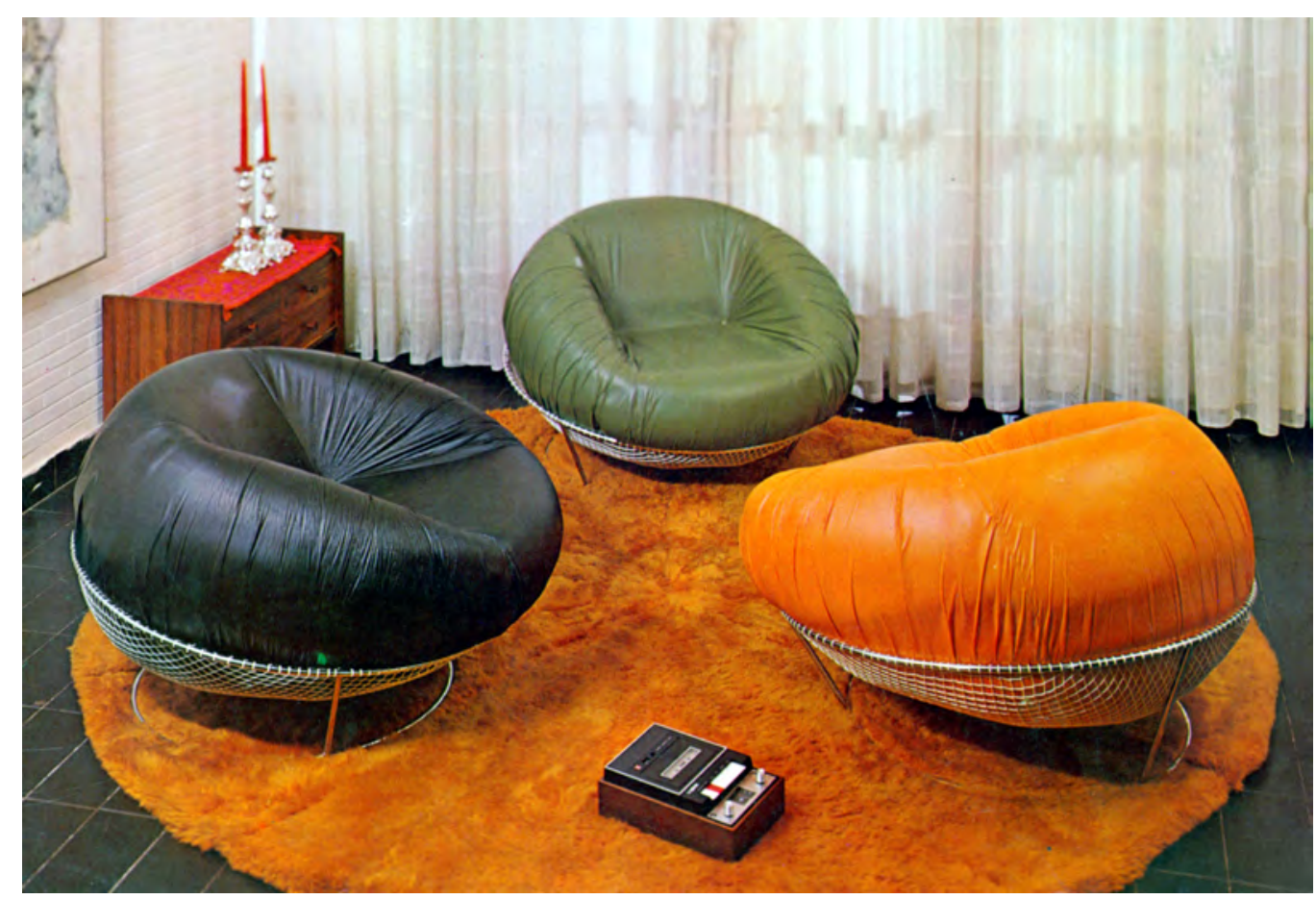


MP119 - 1971

O conjunto MP119 originou uma série de outras poltronas que eram produzidas a partir de espuma injetada revestida. Com apenas pequenas alterações no molde de fibra de vidro, Percival conseguiu produzir uma infinidade de linhas que tinham o puff, como partido conceitual e estético. Essa linha gerou as subsequentes, que receberam pés em diversos materiais e estruturas metálicas embutidas na hora da injeção de espuma no molde

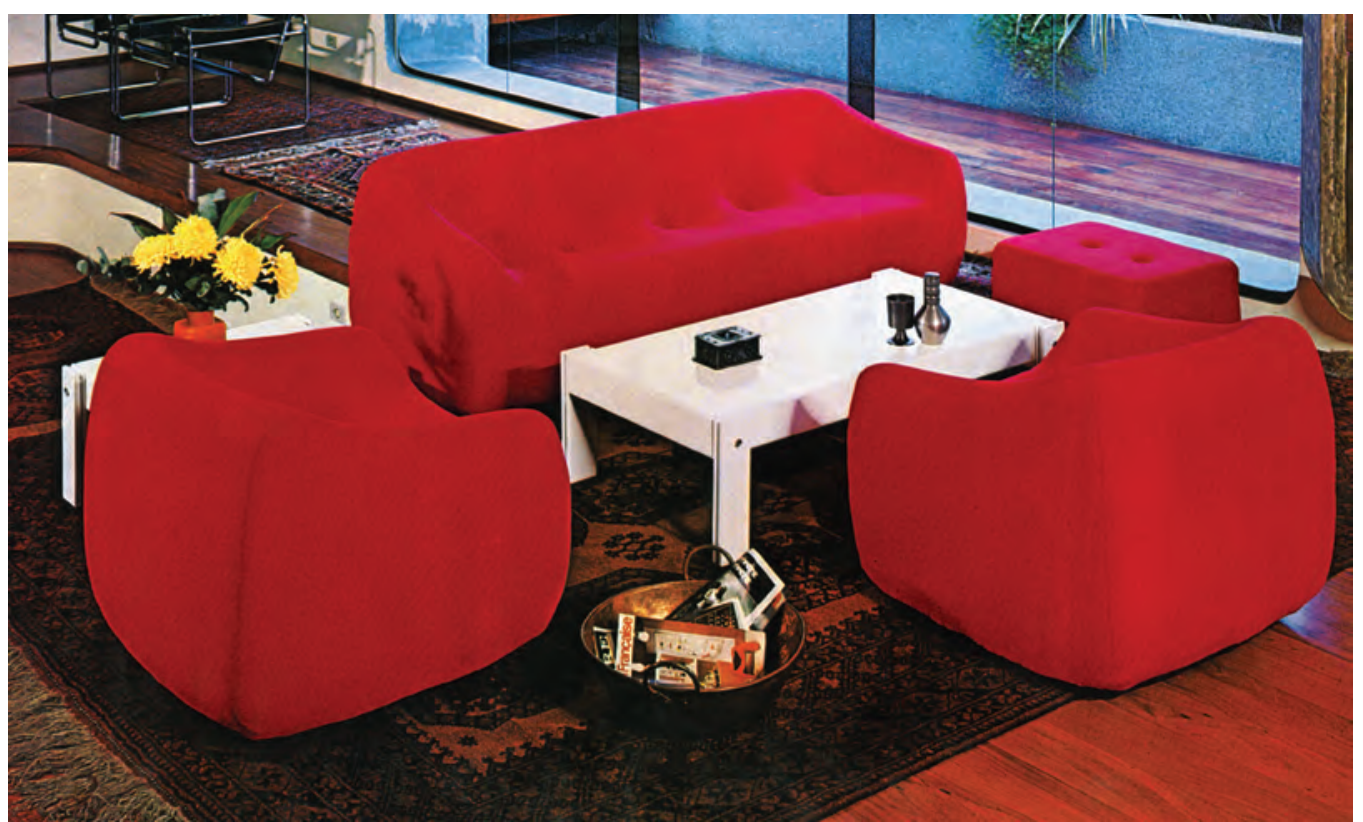

Conjunto de sofá e poltrona MP1971. Sua forma produtiva gerou muitas variações de linhas.

Fonte: arquivo do designer

\section{MP105 - 1972}

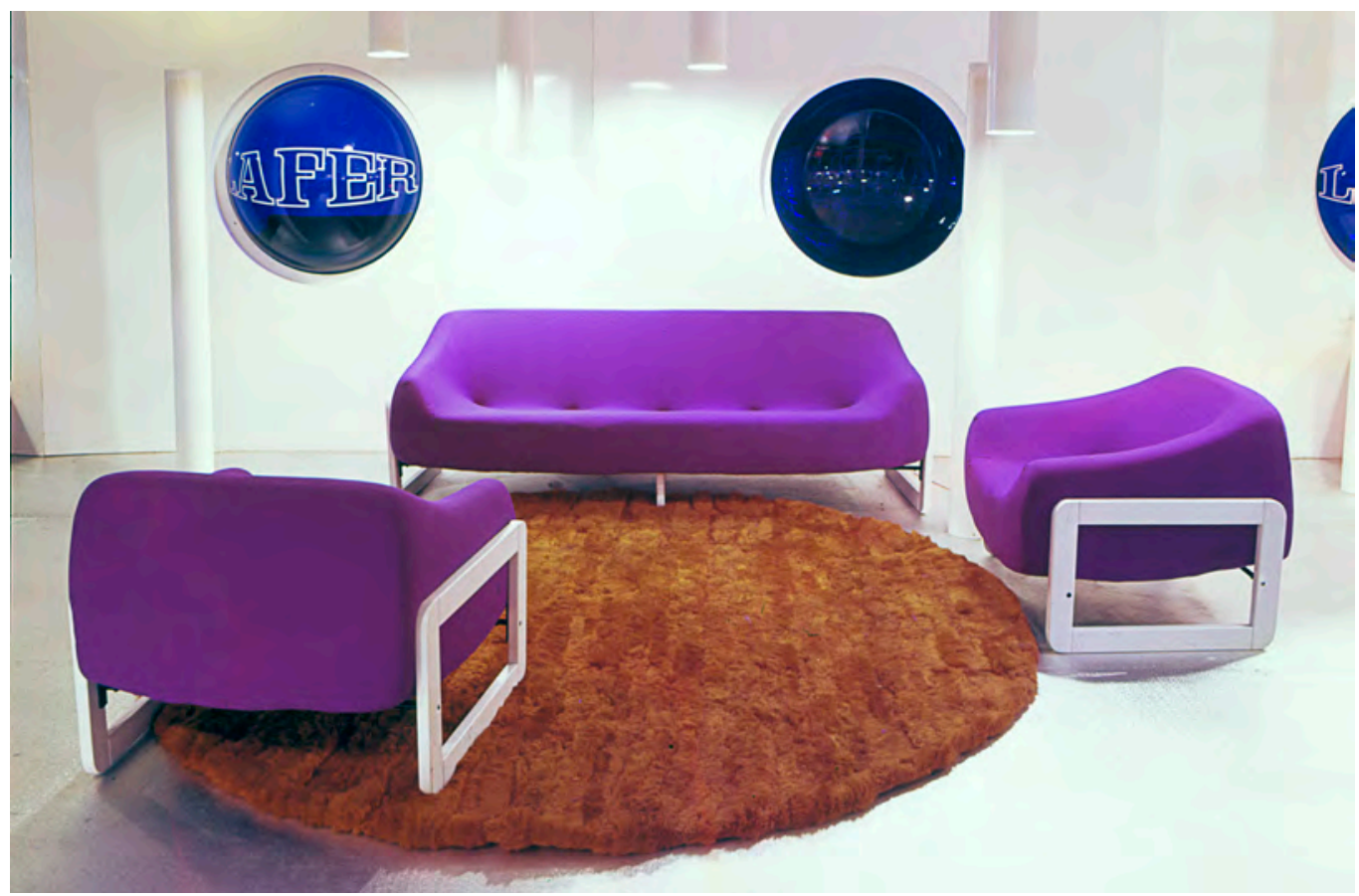

Conjunto de sofá e poltrona MP105. Os móveis foram variações do MP119. A forma de fibra de vidro do MP119 tinha sua base cortada, na produção desta série.

Fonte: arquivo do designer 


\section{MP107}

Poltronas MP107, variação mais luxuosa do MP105, com pés de acrílico ou aço inox.

Fonte: arquivo do designer

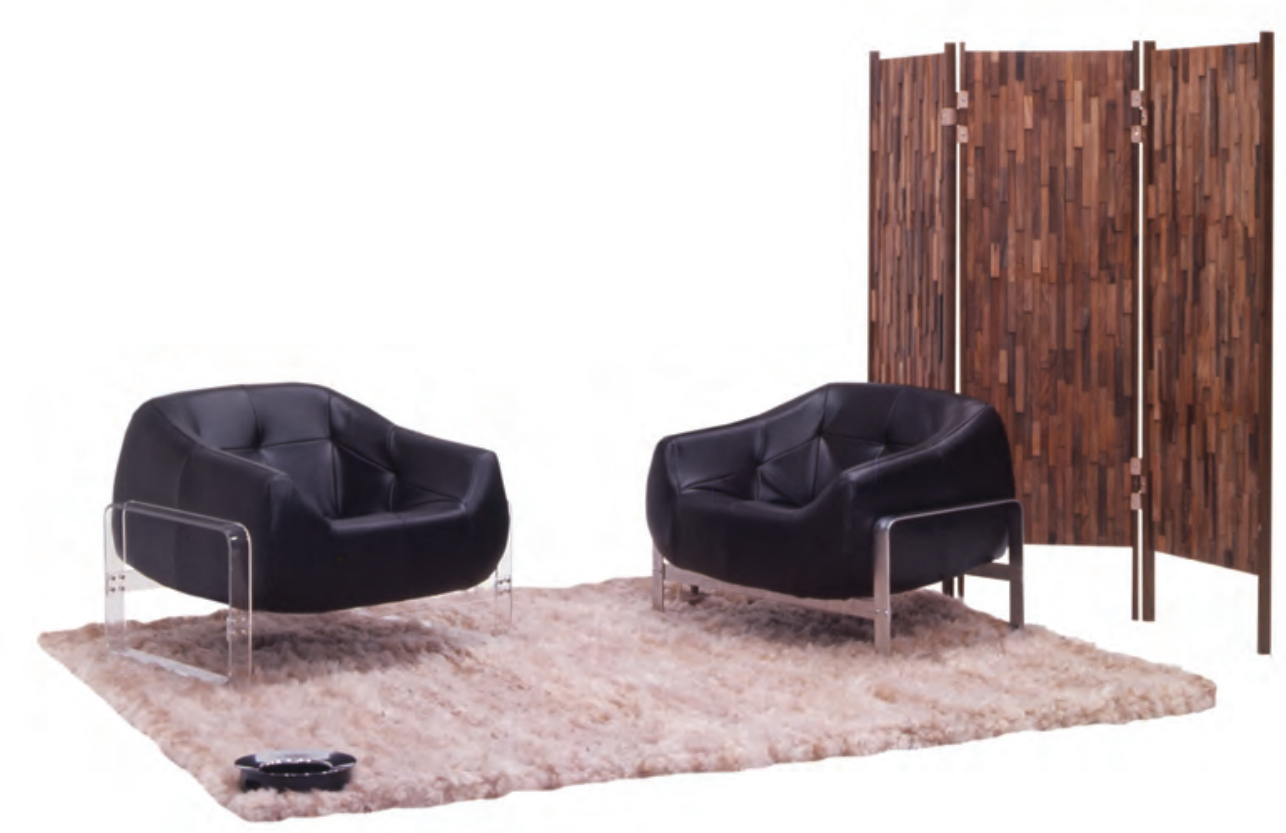

\section{MP113}

$\oplus$

Poltronas MP113,

tem suas linhas

inspiradas nos estofados aeronauticos.

Fonte: arquivo do designer
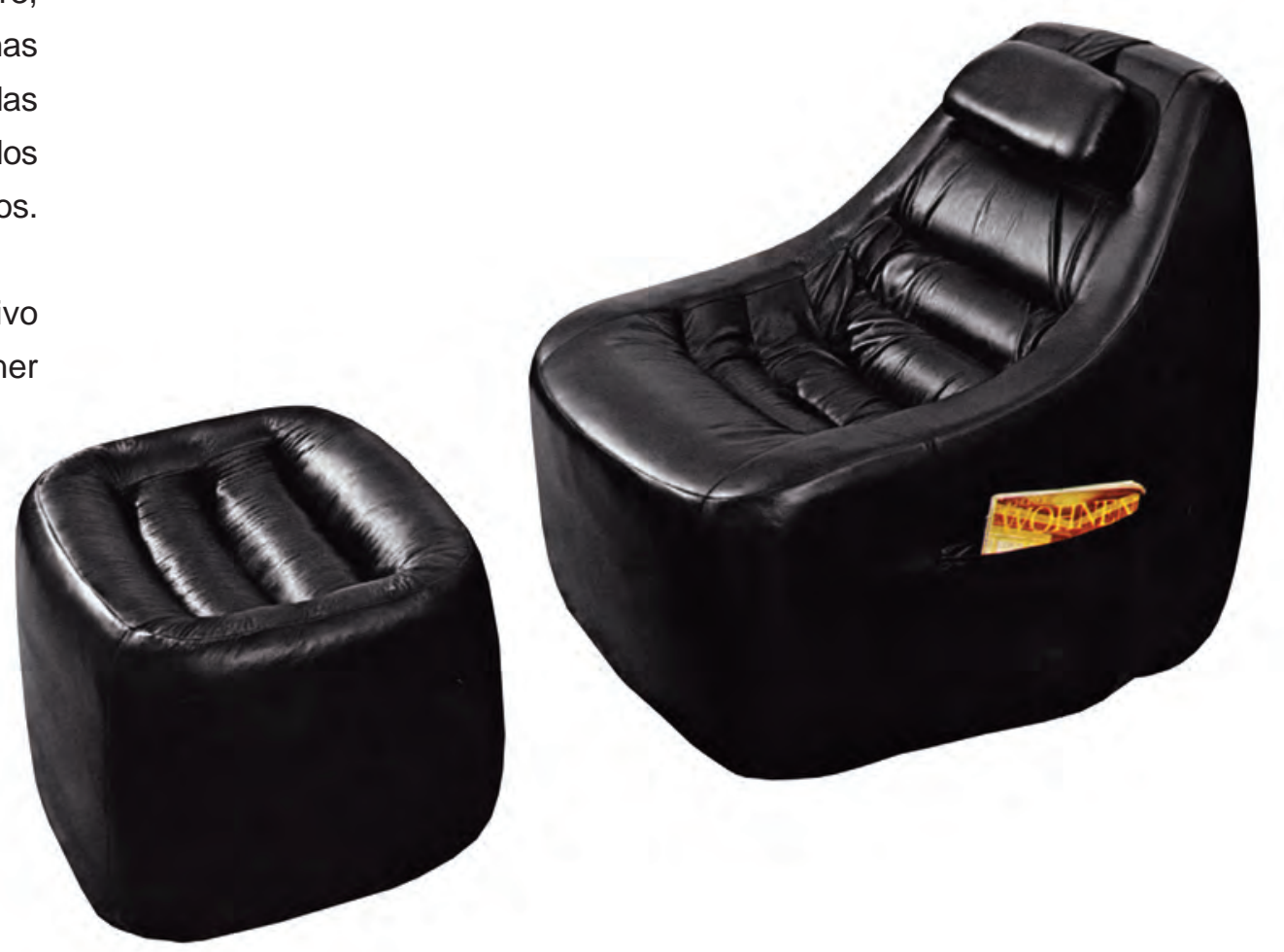


\section{CONJUNTOS MODULARES}

Durante toda sua trajetória, desde seu primeiro móvel, Lafer pensou na componibilidade de partes, dentro de uma perspectiva da seriação, e na modularidade de seus móveis. Normalmente, o ponto de partida era o módulo poltrona, de onde eram derivados os sofás. As marcações de costura e elementos no estofado evidenciavam a multiplicação da unidade da poltrona.

Outros projetos de Lafer se mostraram essencialmente modulares. Nesses casos, a combinatória era resultado de apenas 1 ou 2 elementos que apresentavam formas múltiplas de disposição. Esse princípio de projeto foi pensado especialmente com elementos estofados e marcou um período da criação do designer.

\section{MP 023/ 123}

O MP23, depois reeditado como MP123, é um interessante sistema modular, que pode ser montado conforme a necessidade. Pensado a priori para ambientes corporativos, como salas de espera, o móvel é composto de uma estrutura em aço sobre a qual são acopladas os diversos módulos: cadeira, mesa e revisteiro.

A estrutura primária é composta por perfis ovalados de jacarandá maciço. $O$ estofamento, solto, preso à estrutura por meio de um sistema de cintas de couro. Os outros módulos seguem o mesmo processo.

Conjunto MP023 de poltrona única, versão dos móveis telefônicos dos anos 1950

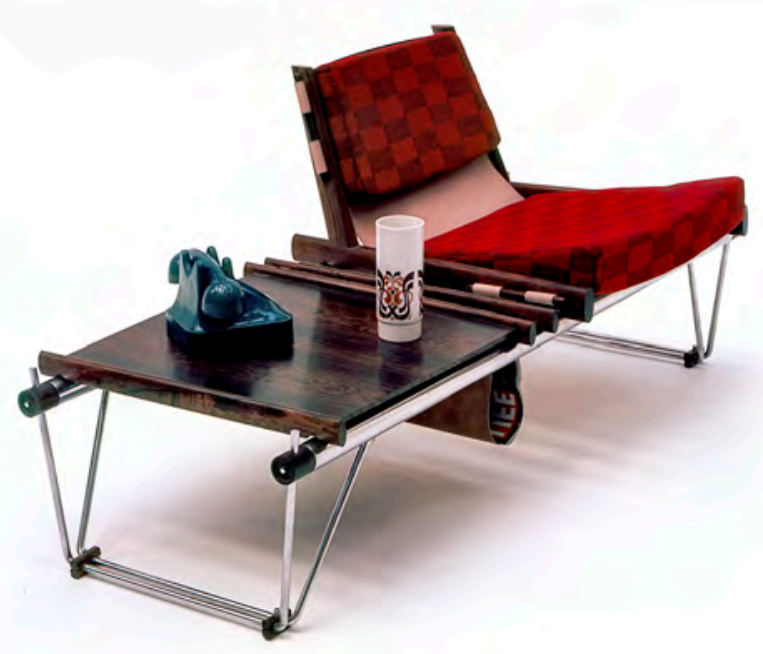

Fonte: arquivo do designer 


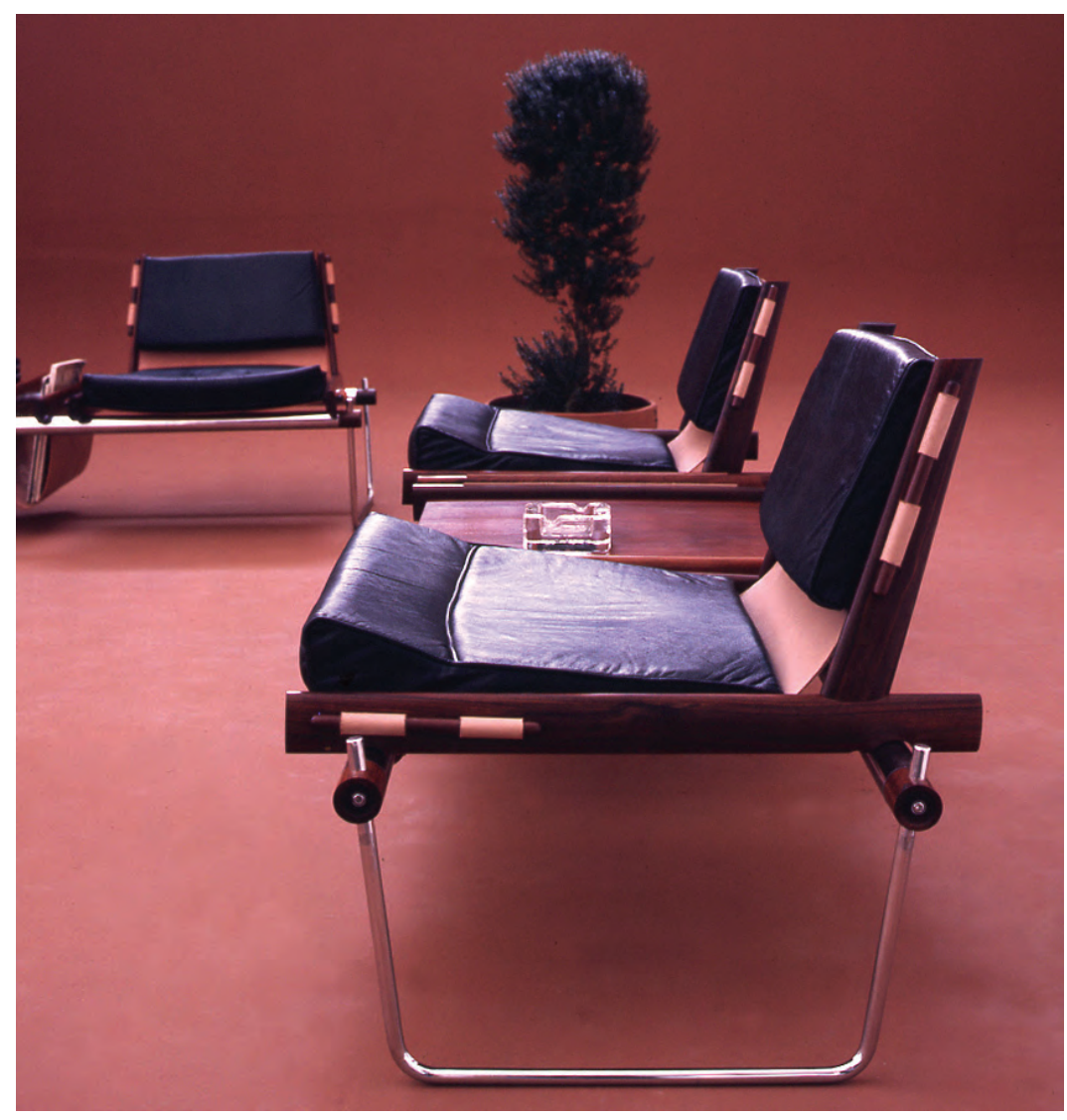

Vista lateral do

conjunto MP023.

O estofado é de

couro, sustentado

por banda

também em

couro tipo sola.

Conjunto MP023

ambientado em

Fonte: arquivo

sala de espera.

do designer

Fonte: arquivo

do designer

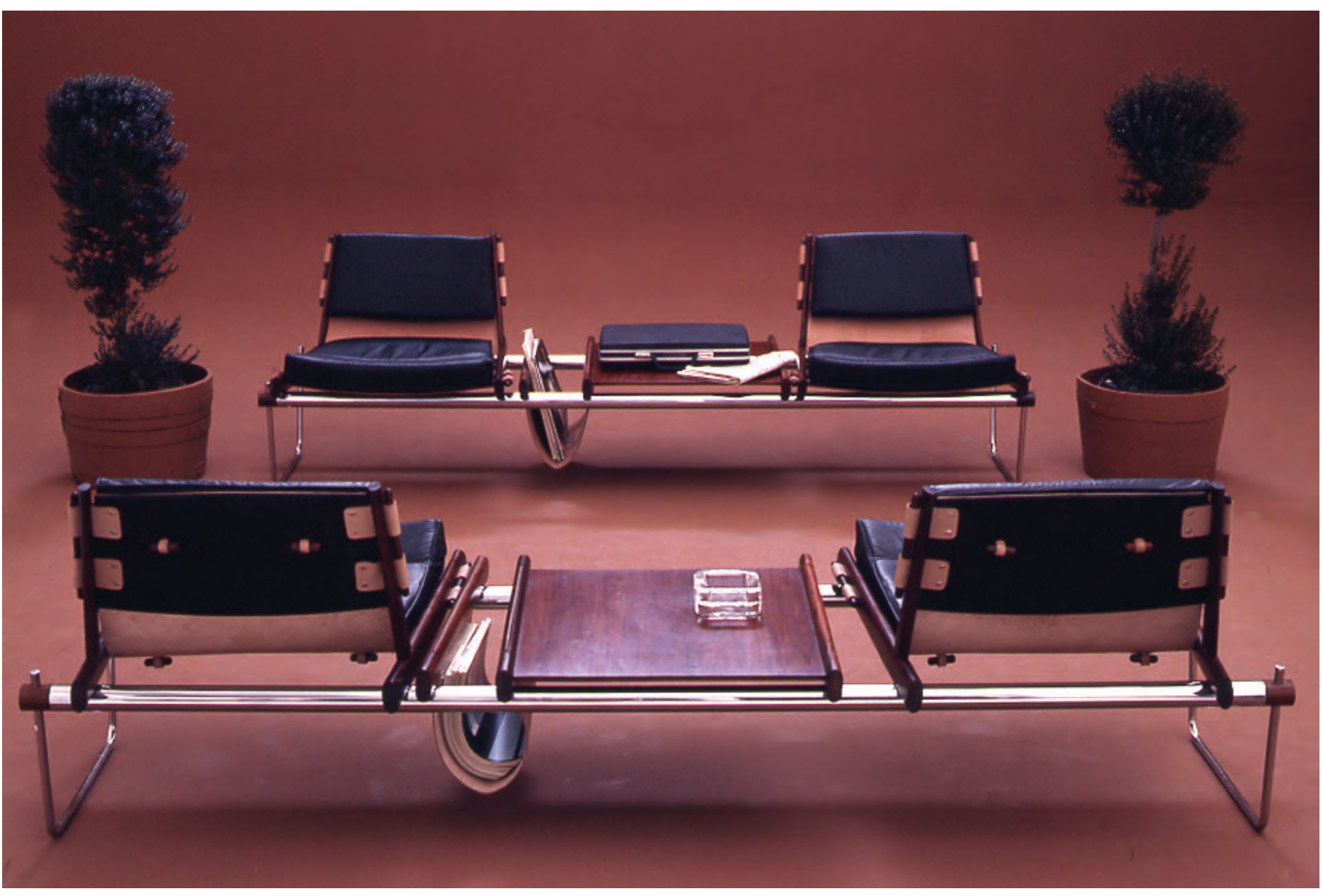




\section{MP115}

Esta poltrona individual que se multiplica em sofá possui desenho expressivo e único. Seu método construtivo diferencia-se dos demais. Assento e encosto se entre travam pelo seu volume. As travas laterais, em tarugo de madeira maciça, unem-se dos dois lados, por meio de perfis metálicos internos ao corpo do estofado. Essas constituem o único elemento construtivo aparente. As travas laterais parecem comprimir o revestimento em couro franzido, que remete aos assentos de tipo "puff", tão em voga nos anos 1970. Não há pés e o estofado encosta diretamente o chão, o que evidencia ainda mais a intenção expressiva do designer.

Poltrona modular MP115.

Fonte: arquivo do designer

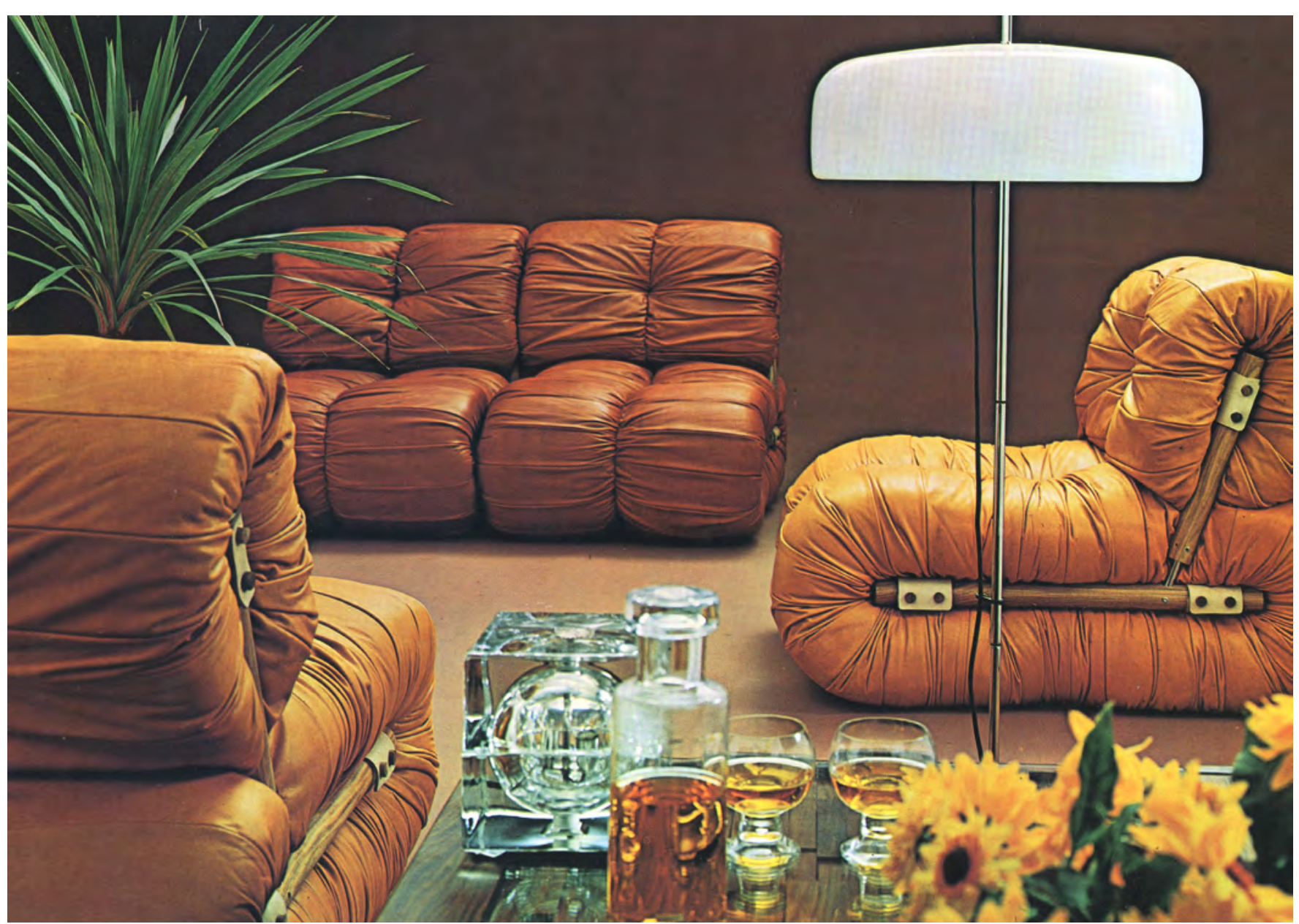




\section{MP141 - 1974}

As duas principais caraterísticas desse conjunto de sala modular são o reaproveitamento de peças pequenas de couro e o sistema escamoteável dos braços, que, quando conveniente, podem ser integrados ao assento. O dispositivo de movimento era inovador e apontava para as experiências em curso com a produção dos sofás-camas. A pesquisa em movimento foi imprescindível para a viabilidade do projeto das reclináveis, produto de

Conjunto modular MP141, com módulos de sofá, mesa lateral e puff.

Fonte: arquivo do designer primeira linha da Lafer.

Outros dispositivos de encaixe foram desenvolvidos e aplicados às linhas subsequentes. Na maioria dos casos, cada módulo era preso ao outro, por meio de baionetas escondidas no estofado. Esse dispositivo foi usado para encaixe de encostos, braços e intermódulos.

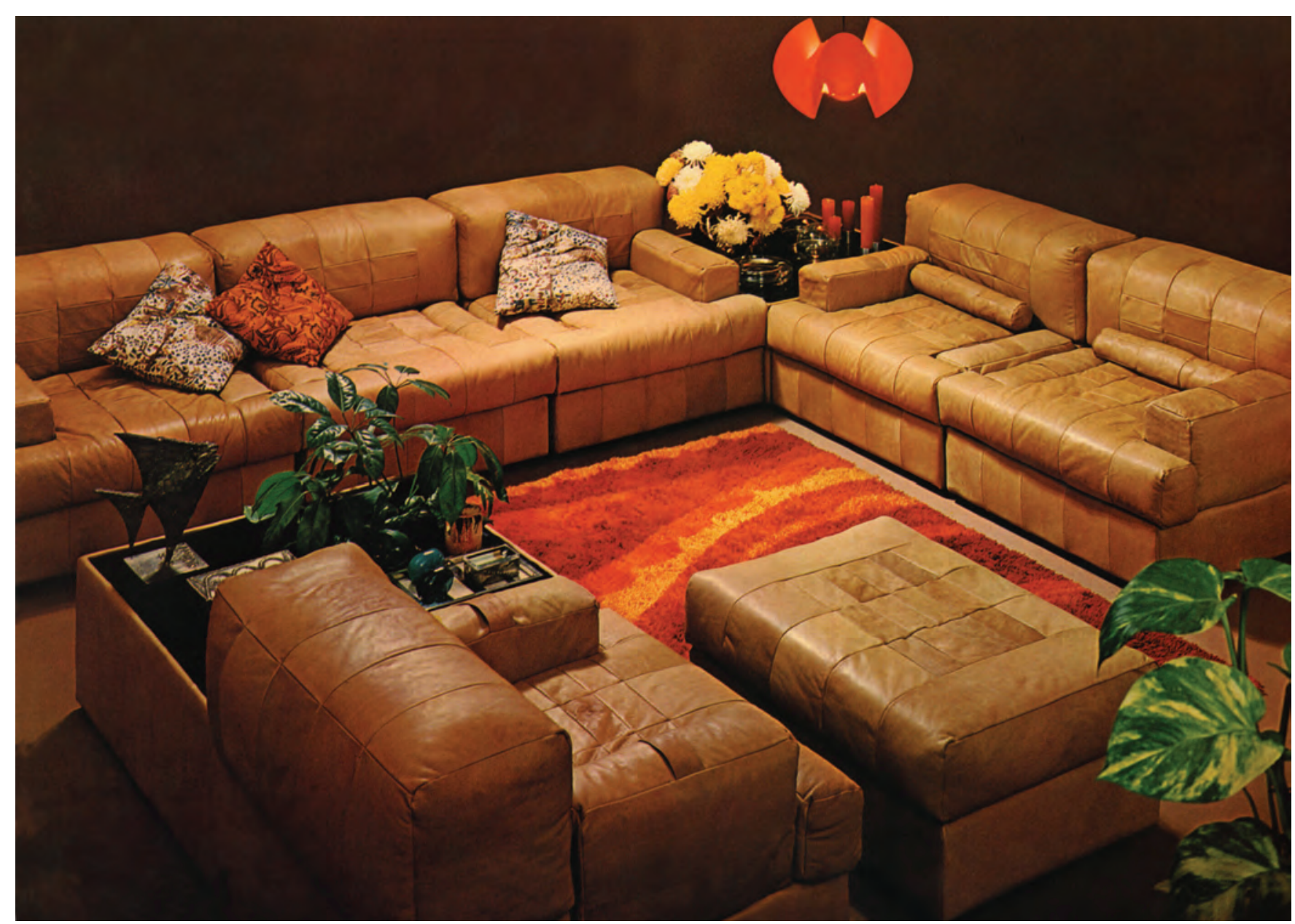




\section{MP125}

A linha de sala MP125 foi pensada para pequenos espaços. Seu conceito é versatil. Cada módulo contém em si diversas funções. A unidade da poltrona possui encosto escamoteável o que possibilita a montagem de chaises e camas. A união das diversas poltronas foram o sofá. De estrutura simples em fibra de vidro o estofado é aparafusado por meio de componentes metálicos presentes dentro de sua espuma.

As mesas que compõe o conjunyo são as bases do sofá, e podem ser usadas também como containers.

Conjunto modular

MP125, com módulos de sofá, mesa lateral e puff.

Fonte: arquivo do designer

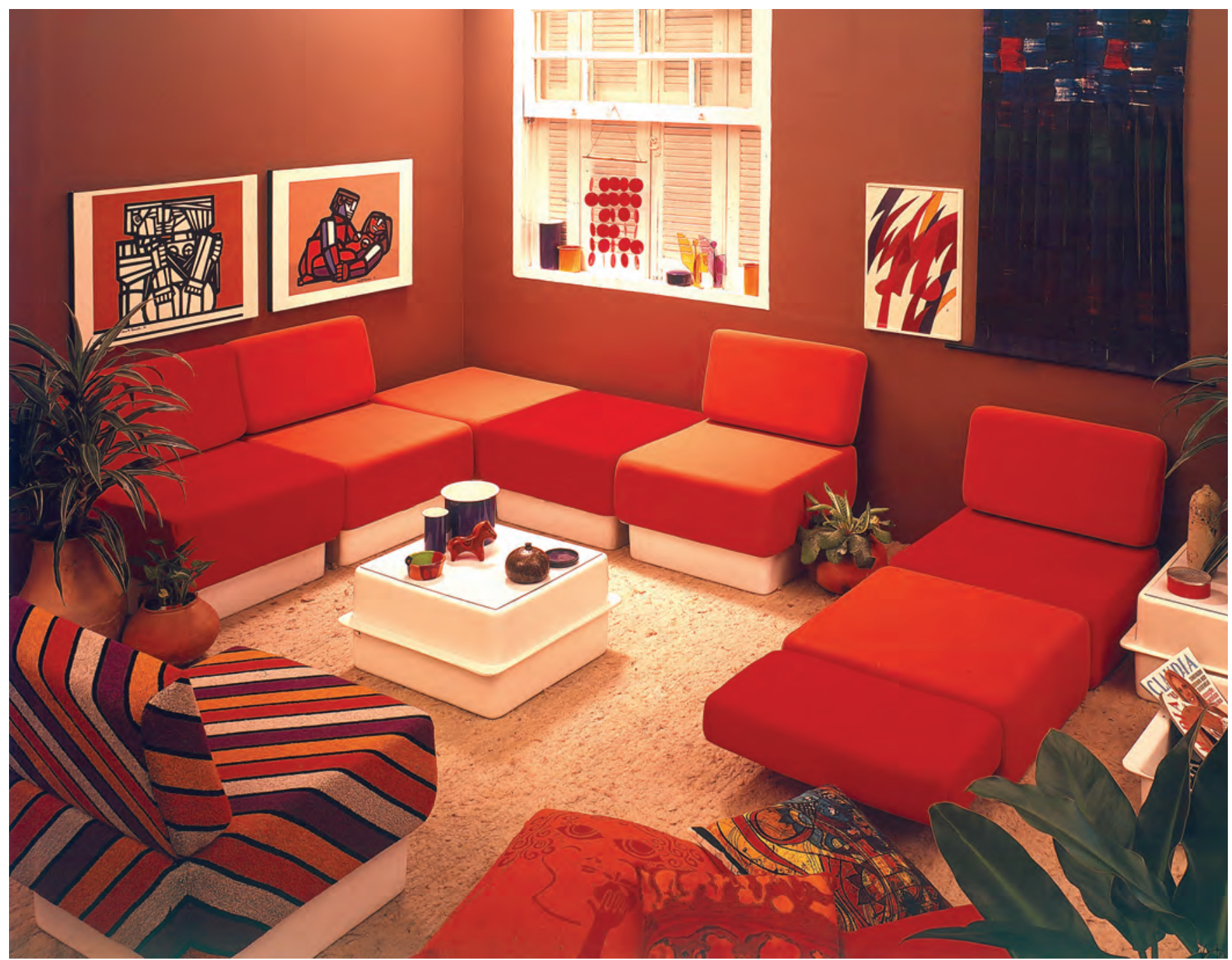




\section{LINHAS ESPECIAIS}

\section{MP LAFER 'CONTEMPO'}

'Contempo' foi uma linha especial desenvolvida por Lafer dentro do campo do mobilliário. Além de contemplar todas as tipologias de móveis presentes no âmbito da casa, ela possuía uma linguagem própria de desenho e projeto. A versatilidade e otimização do uso das peças de mobiliário durante sua vida útil foram os pontos de partida. Percival pensou as peças a partir de uma industrialização simplificada, reduzindo os elementos a serem produzidos e aumentando sua possibilidade combinatória, para gerar diversos usos. Os componentes eram basicamente pés em forma de T invertido, sobre os quais eram montados perfis metálicos de seção redonda, que, conforme a sua dobradura e angulação de encaixe, formam os mais diversos móveis. A combinação entre madeira e metal, bem como a fácil desmontabilidade e empacotamento, permaneceram uma tônica.

A linha era composta por sofá, poltrona, cadeira, mesa de jantar, escrivaninha, cama, estante e, até mesmo, berço. Era possível adquirir jogos de elementos e transformá-los com opções de revestimento laváveis. Alguns móveis eram intercambiáveis entre si: o berço, por exemplo, poderia virar um console, com a adição de um tampo de vidro.

Croqui do sistema estrutural e conceitual da poltrona Contempo. A compactibilidade era um ponto importante para a exportação e estoque dessa linha

Fonte: arquivo do designer

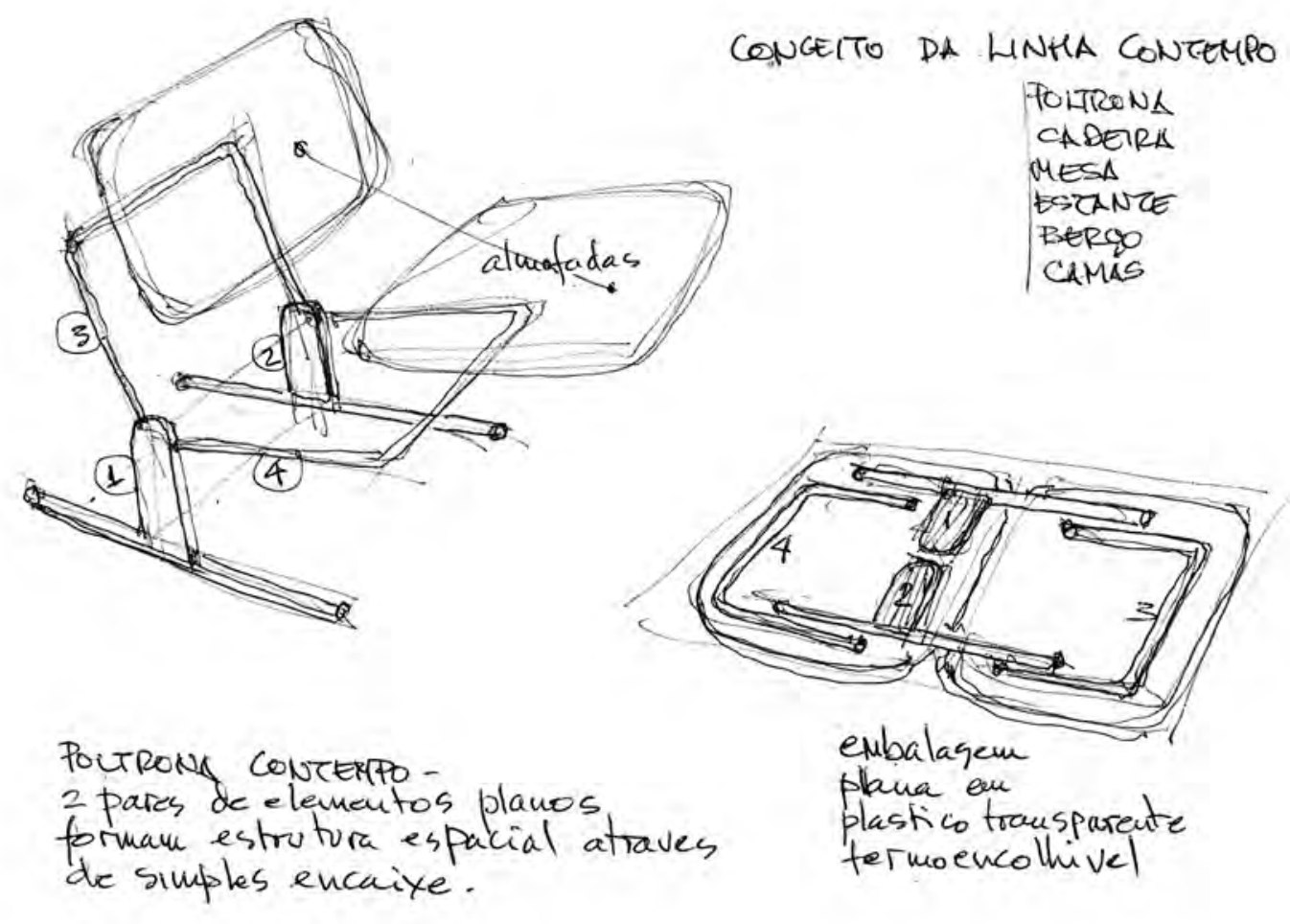


Em seu memorial descritivo, Percival pondera alguns pontos importantes sobre produção e distribuição desse mobiliário. O primeiro ponto é a produção de uma linha residencial completa, algo até então, não experimentado pelo designer. A estrutura básica era vendida, sendo que os complementos de revestimento podiam ser trocados, conforme a vontade do comprador. Percival diz que essa dinâmica deveria funcionar à maneira de roupa de cama. Todos os tecidos poderiam ser trocados, conforme coleções e propostas de outros designers.
Anuncio, foto da poltrona e croqui, evidenciando as

possibilidades

de troca de revestimento

e capas.

Fonte: arquivo do designer

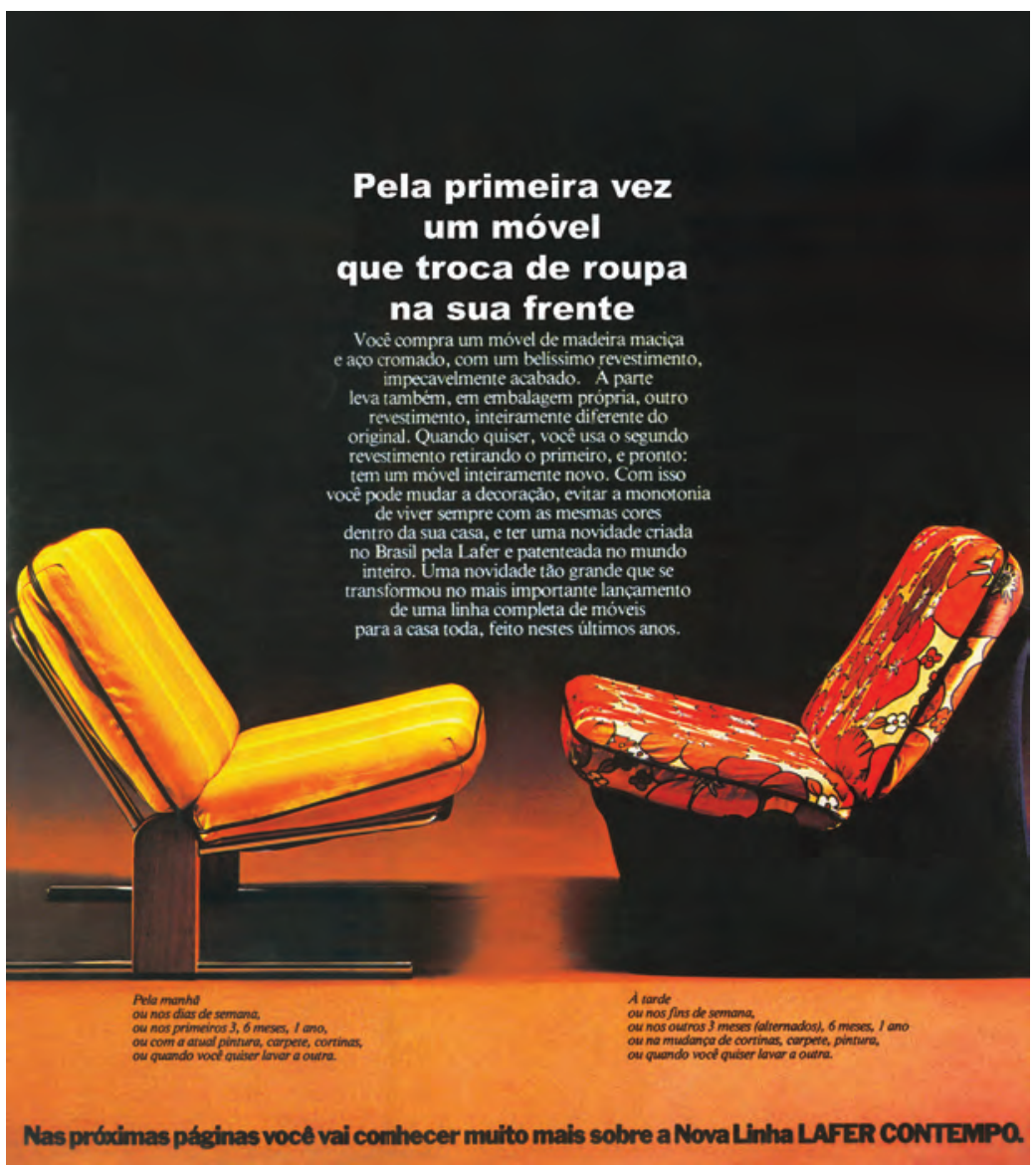

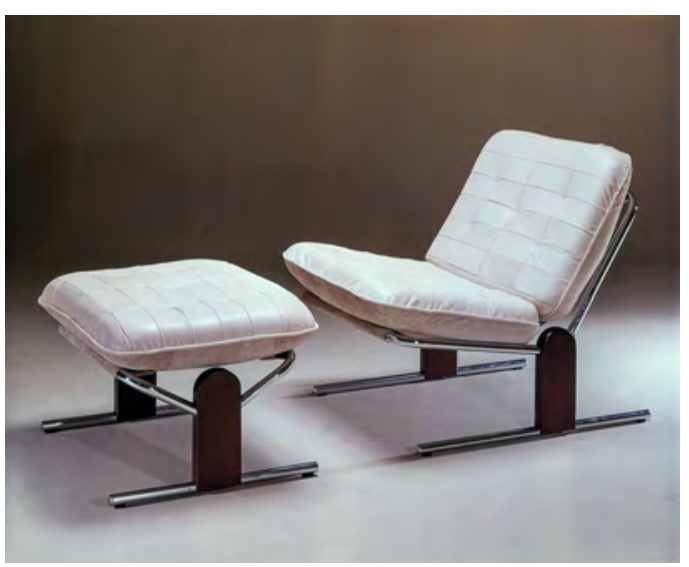

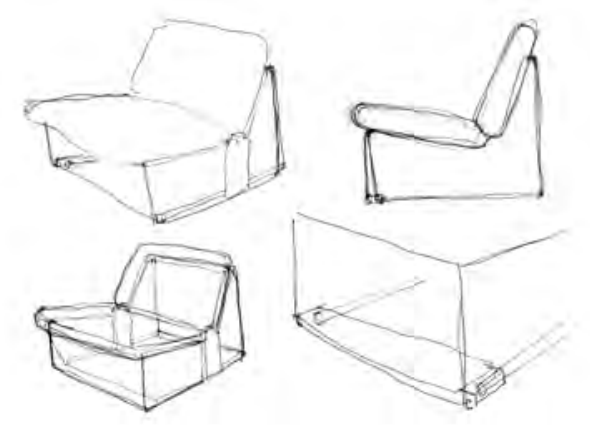

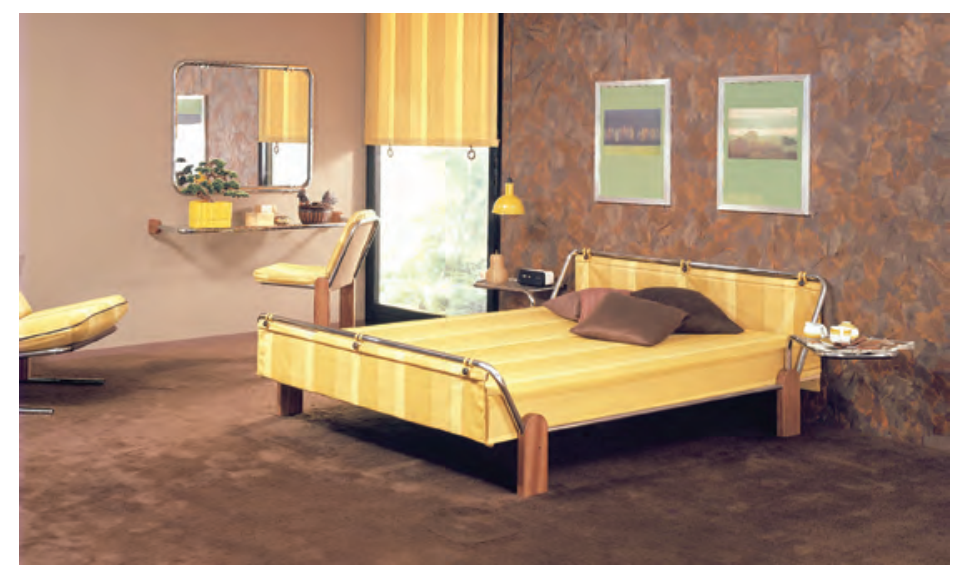


Outra característica importante é a de que os produtos foram pensados para serem vendidos nas prateleiras. A fácil estocagem exigia baixo custo de investimento, enquanto as capas e revestimentos, vendidos separadamente, consolidavam a base de um comércio próprio. Os produtos se propunham a serem montados pelo cliente: a simplicidade e ausência de parafuso e ferragens complicadas facilitava esse procedimento. Percival queria envolver o comprador, por meio da estratégia marqueteira do faça você mesmo. Até mesmo as cores da estrutura poderiam ser mudadas, conforme o revestimento escolhido. Há, nesse aspecto, uma aproximação da lógica da moda, enquanto paradigma de produção e consumo. A personalização se torna foco central da proposta publicitária. O produto deveria aparentar ser único para cada qual. Esse pensamento, apesar de ter sido engendrado nos ano 77, é, mercadologicamente, bem atual.

Ambiente completamente mobiliado com móveis da linha contempo,

Fonte: arquivo do designer

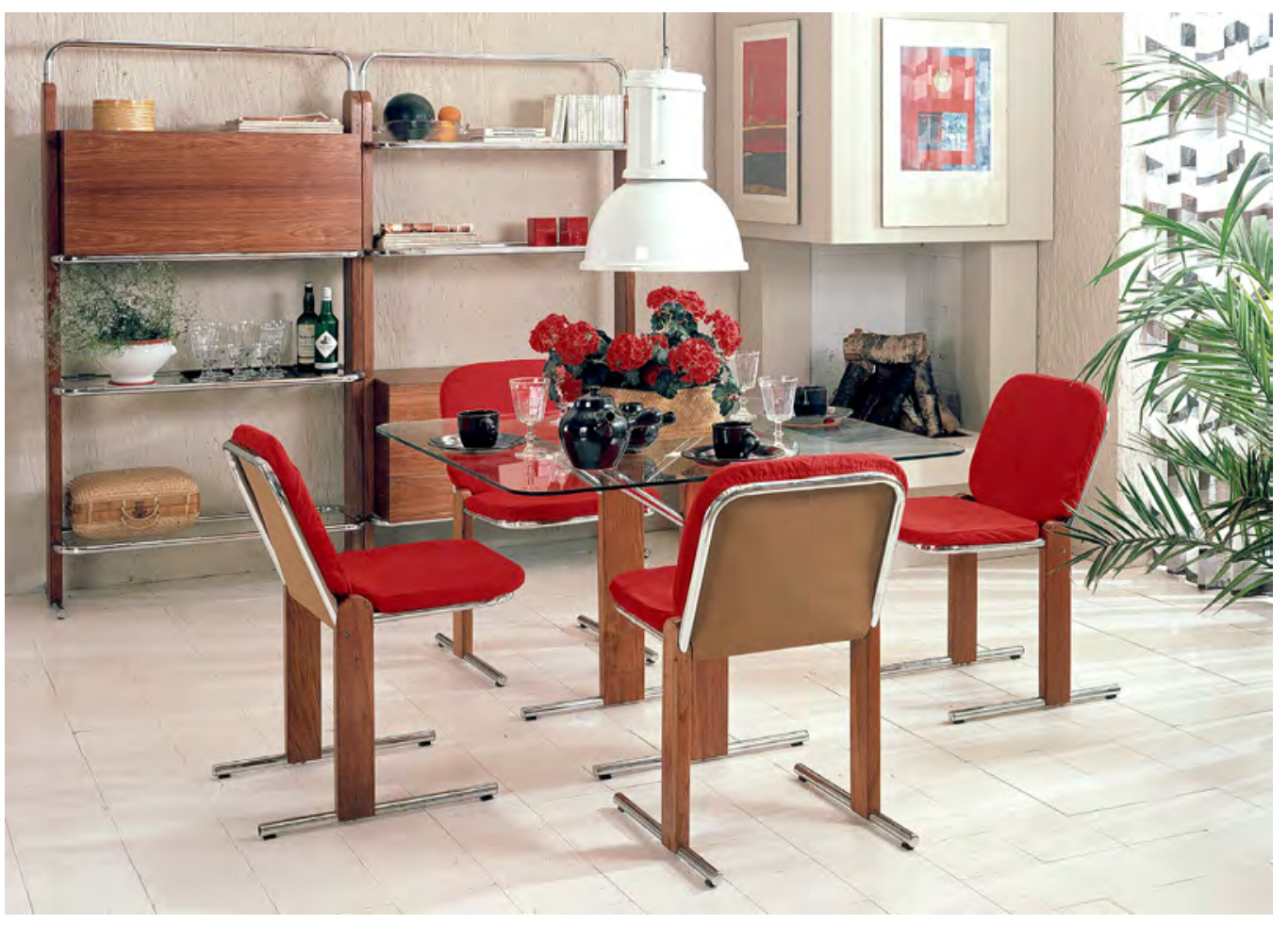

Camas,

criado mudo,

penteadeira e

outros módulos

de quarto da

linha Contempo

Fonte: arquivo do designer

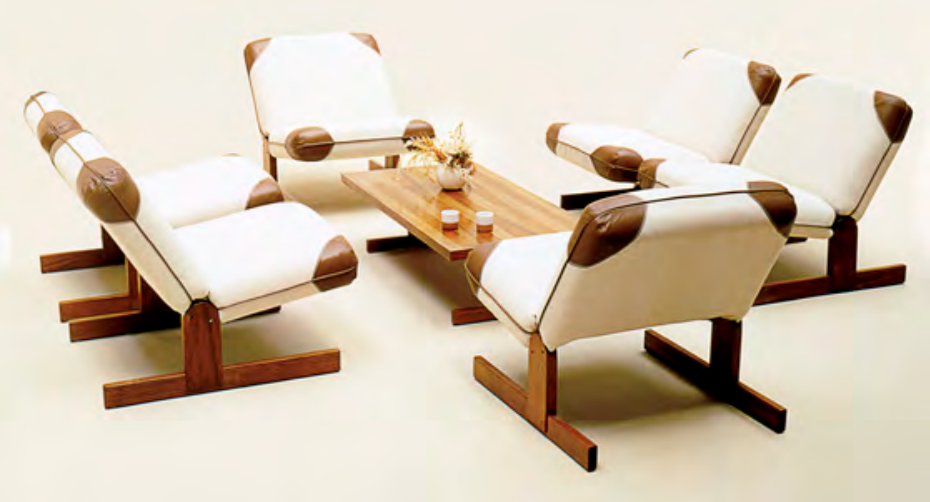

Cariação

da poltrona

Contempo, com pés de madeira maciça.

Fonte: arquivo do designer 



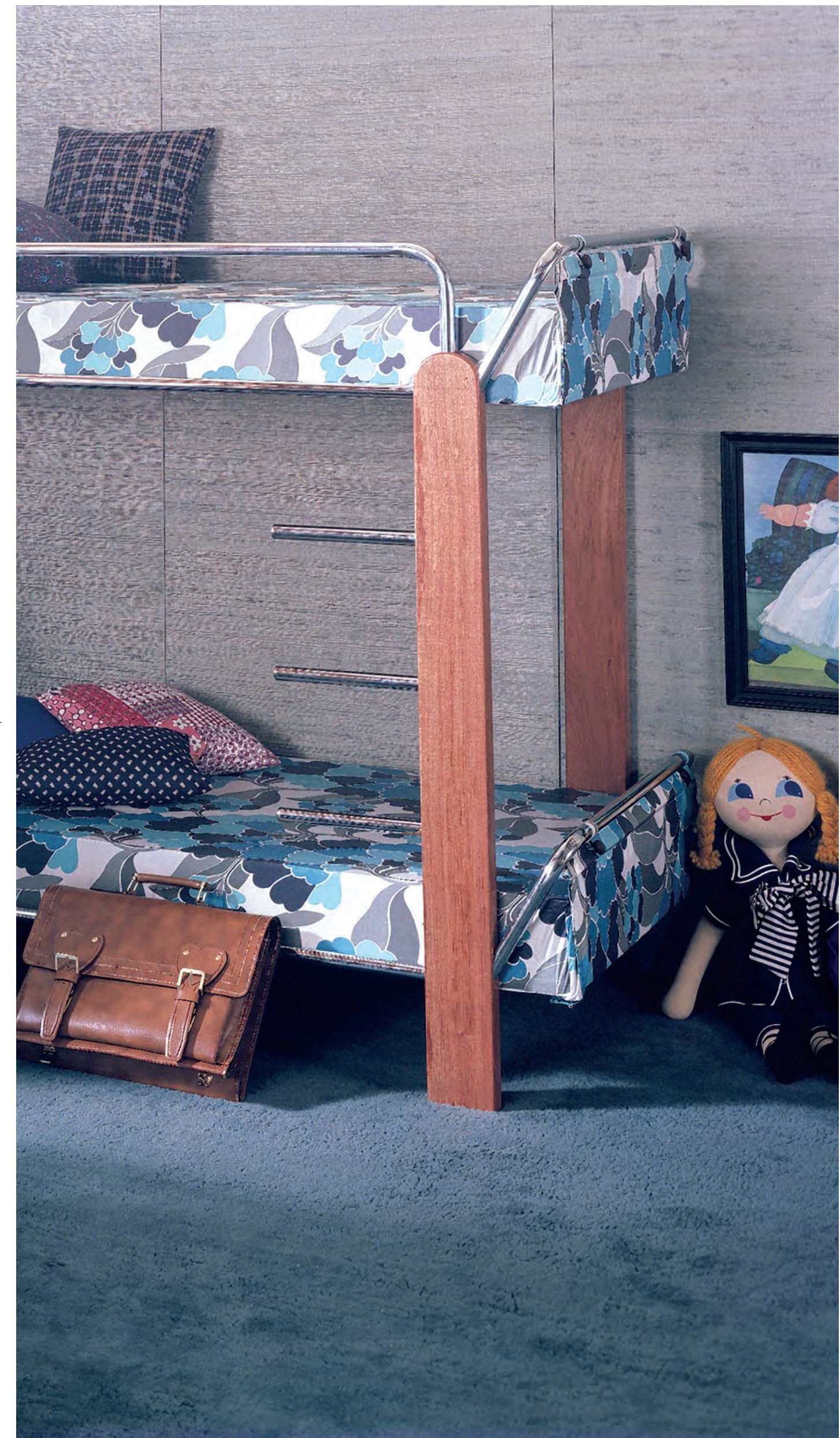

Quarto infantil inteiramente

mobiliado com beliche, berço e cadeira da linha Contempo

Fonte: arquivo do designer 


\section{WOODSTICK}

O sistema Woodstick nasceu da ideia de reuso de pedaços de madeira nobre, rejeitos do processo de fabricação de algumas peças. O sistema foi usado na confecção de mobiliários como mesa de centro e outros, mas a ideia principal era a fabricação de painéis de revestimento. Conjuntos foram vendidos. A solução de acabamento de rodapés e cantos era completa e previa diversas situações de aplicação.

Os módulos eram compostos basicamente de uma chapa de Duratex, sobre a qual eram colados os pedaços de madeira maciça, em especial, pau-ferro. Os painéis possuíam uma junção tipo quebra-cabeça, o que possibilitava a junção e fixação invisíveis. O produto foi amplamente exportado, principalmente para a Alemanha. Sua produção acabou, quando, por motivos econômicos, o uso da madeira maciça passou a ser restrito.

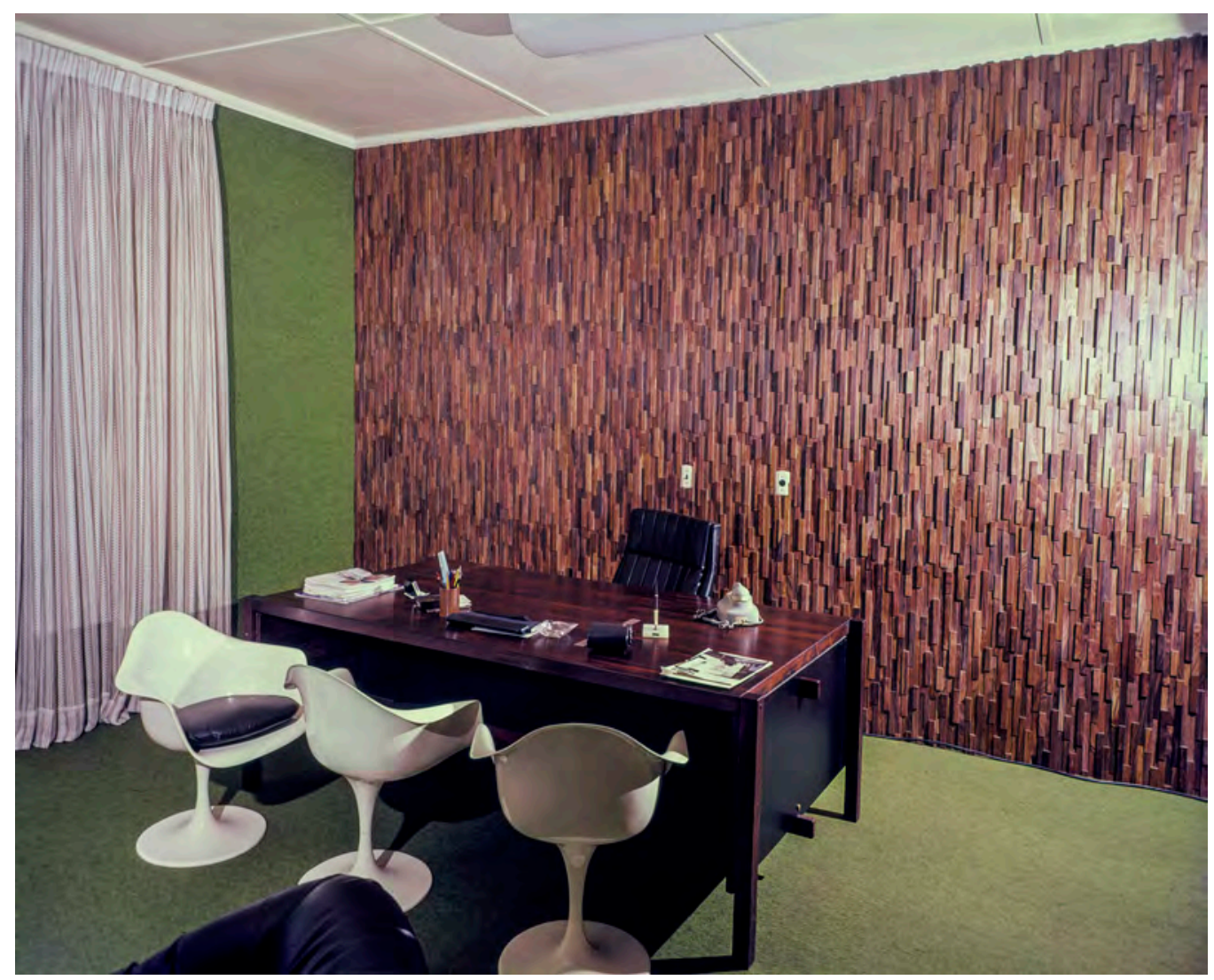

Painel montado com módulos da linha Woodstick.

Fonte: arquivo do designer

Embalagens e linha de produç $\sim$ çao do Wood stick

Fonte: arquivo do designer
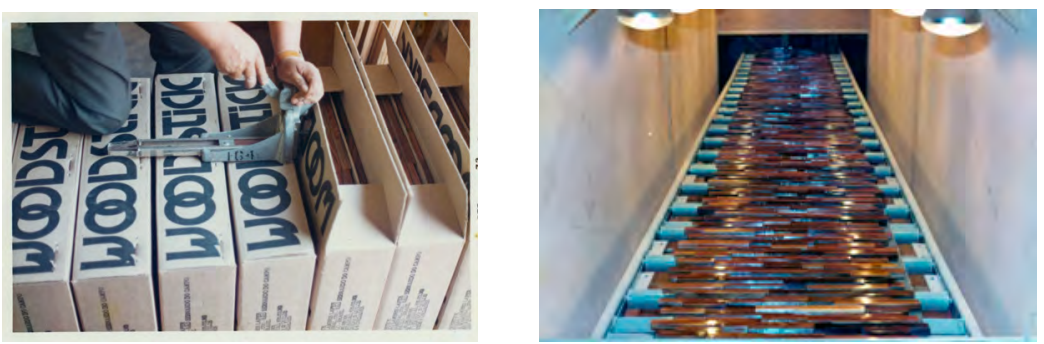
Mesas dobráveis, desenvolvidas a partir daos módulos de painel woodstick

Fonte: arquivo do designer
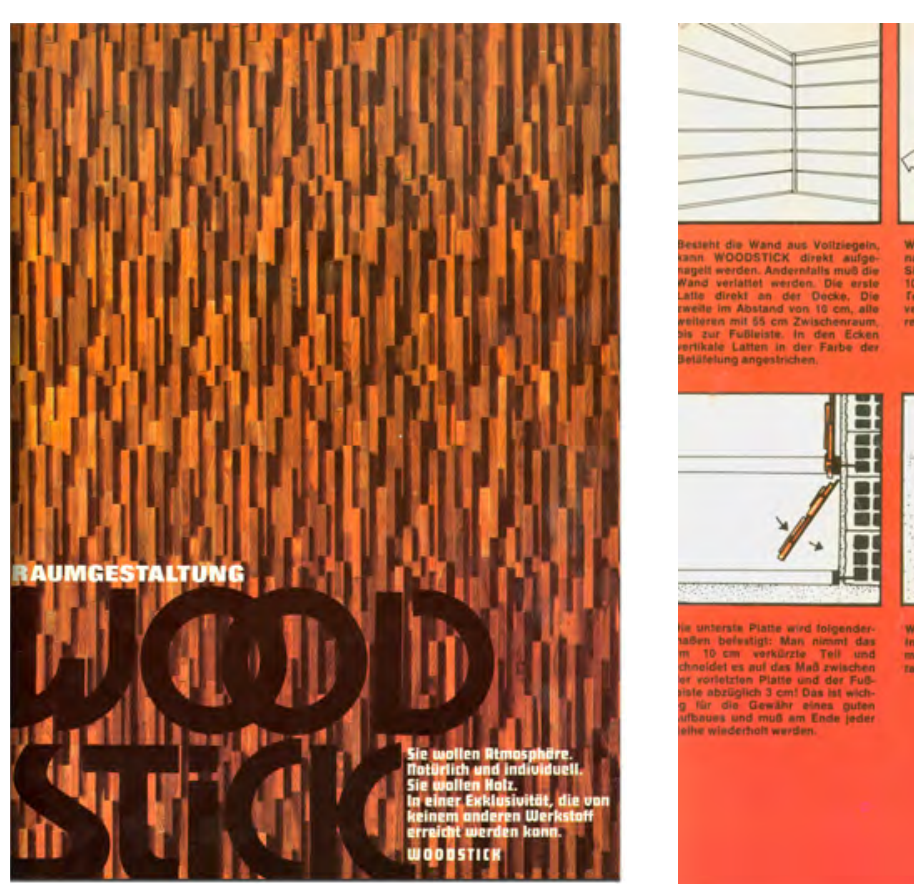

Frente e verso do planfeto de venda do Woodstick. No verso, encontram-se as instruçlões de montagem e acabamento

Fonte: arquivo do designer

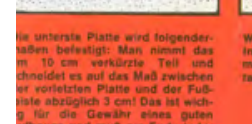

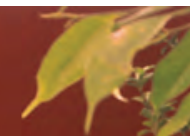
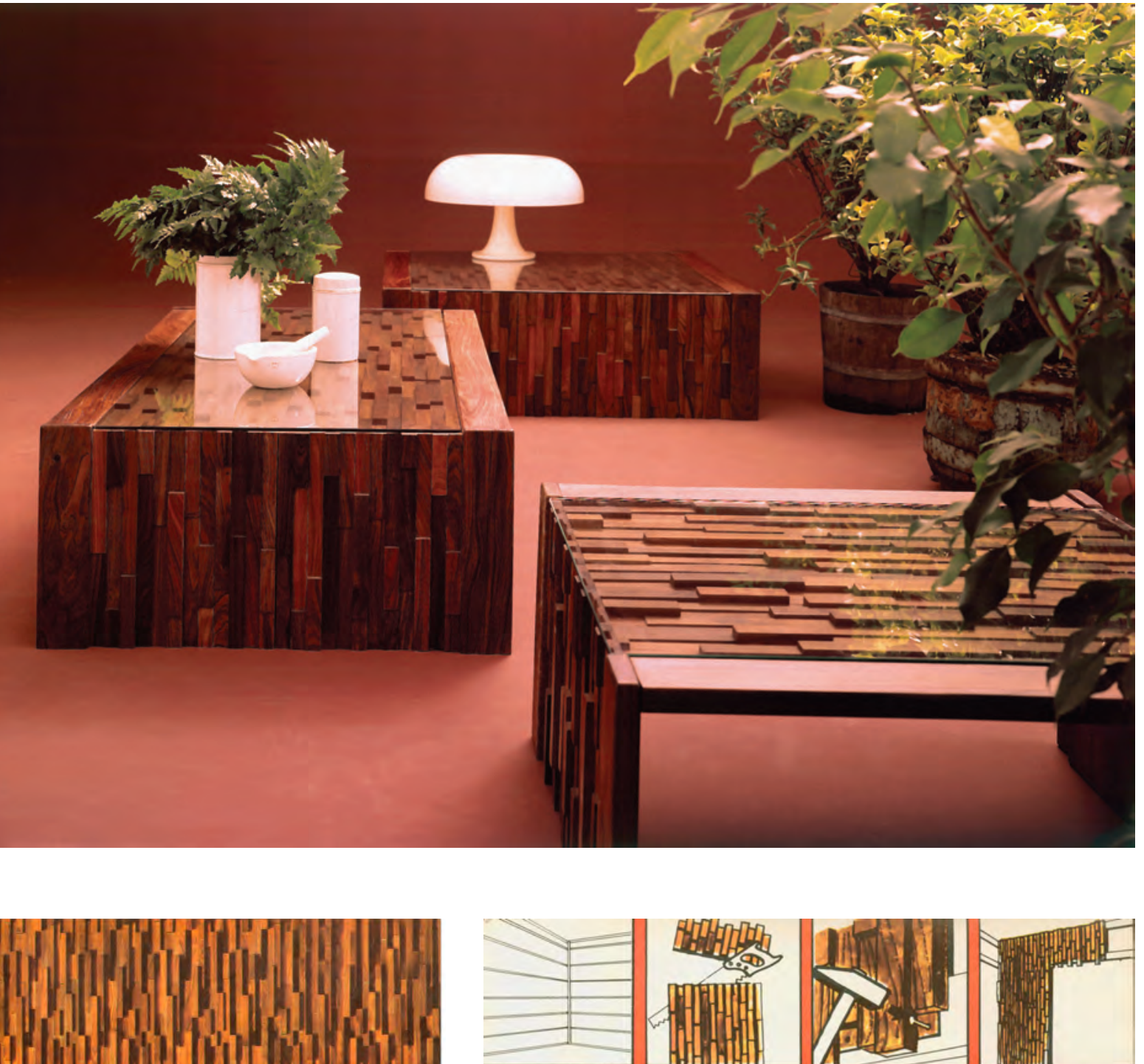

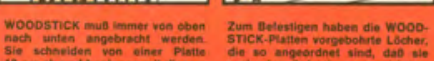

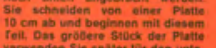

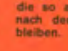
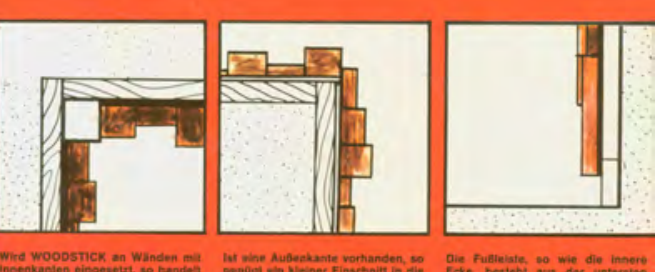

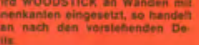

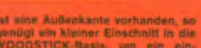

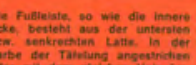

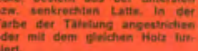

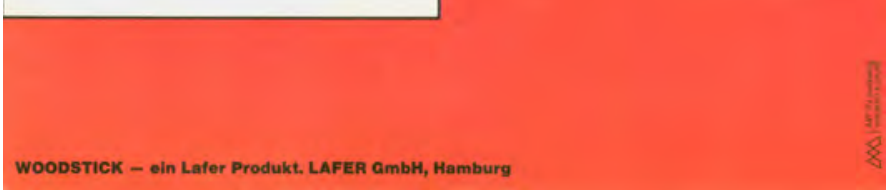




\section{LINHAS PAÍSES}

A partir do começo dos anos 1980, novas políticas produtivas começaram a ser adotadas devido ao contexto econômico de recessão que se instaurou no país no final da ditadura militar. Nesse momento, Percival começou a utilizar madeiras mais baratas, e, dentro de uma perspectiva produtiva e estética inspirada no modelo IKEA, o designer desenvolveu a linha Países. Com custo produtivo mais baixo e desenho neutro, conquistou uma maior amplitude de mercado. O Pinus Eliotti, cultivado em terrenos de propriedade do designer, começou a ser utilizado como alternativa a madeiras maciças mais raras e caras. Até então a MP Lafer havia consumido grandes quantidades de jatobá e lei.

Estruturas e estofados eram muito simples. No caso da linha Suécia o estofamento se tornou o eixo conceitual do desenho das peças. Os desenhos seguiam o padrão médio europeu, e muitos deles foram fortemente inspirados pela criação da designer italiana Cini Boeri.

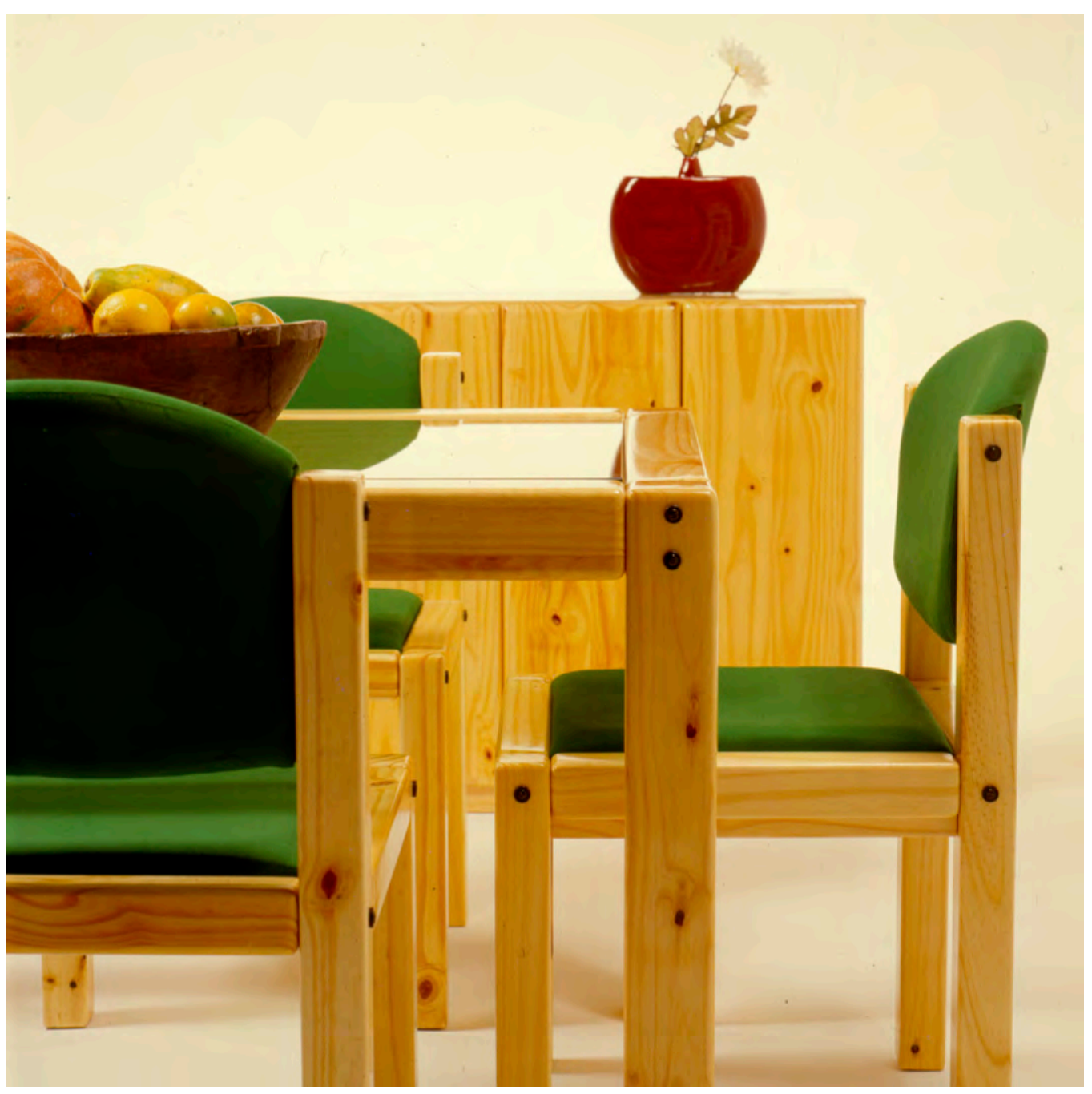

Sala de jantar completa da linha Lafer Finlândia.

Fonte: arquivo do designer 


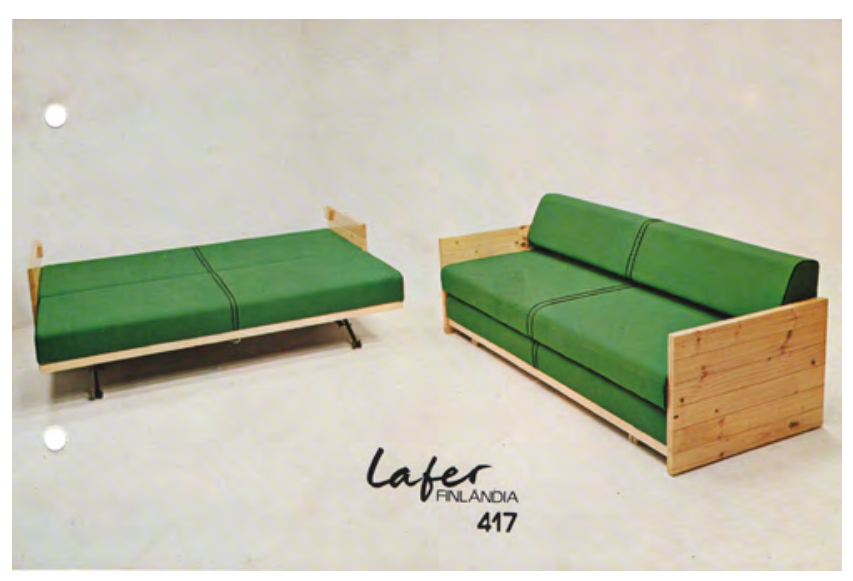

Variações e conjuntos da linha

Finlândia, inteiramente fabricada com pinus de reflorestamento.

Fonte: arquivo do designer

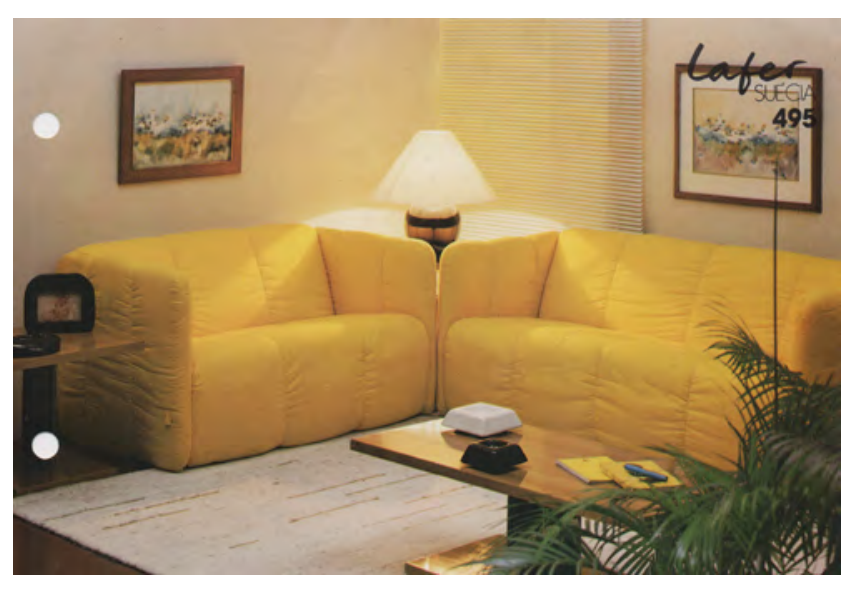

conjuntos estofados da linha Lafer Suécia.

Fonte: arquivo do designer
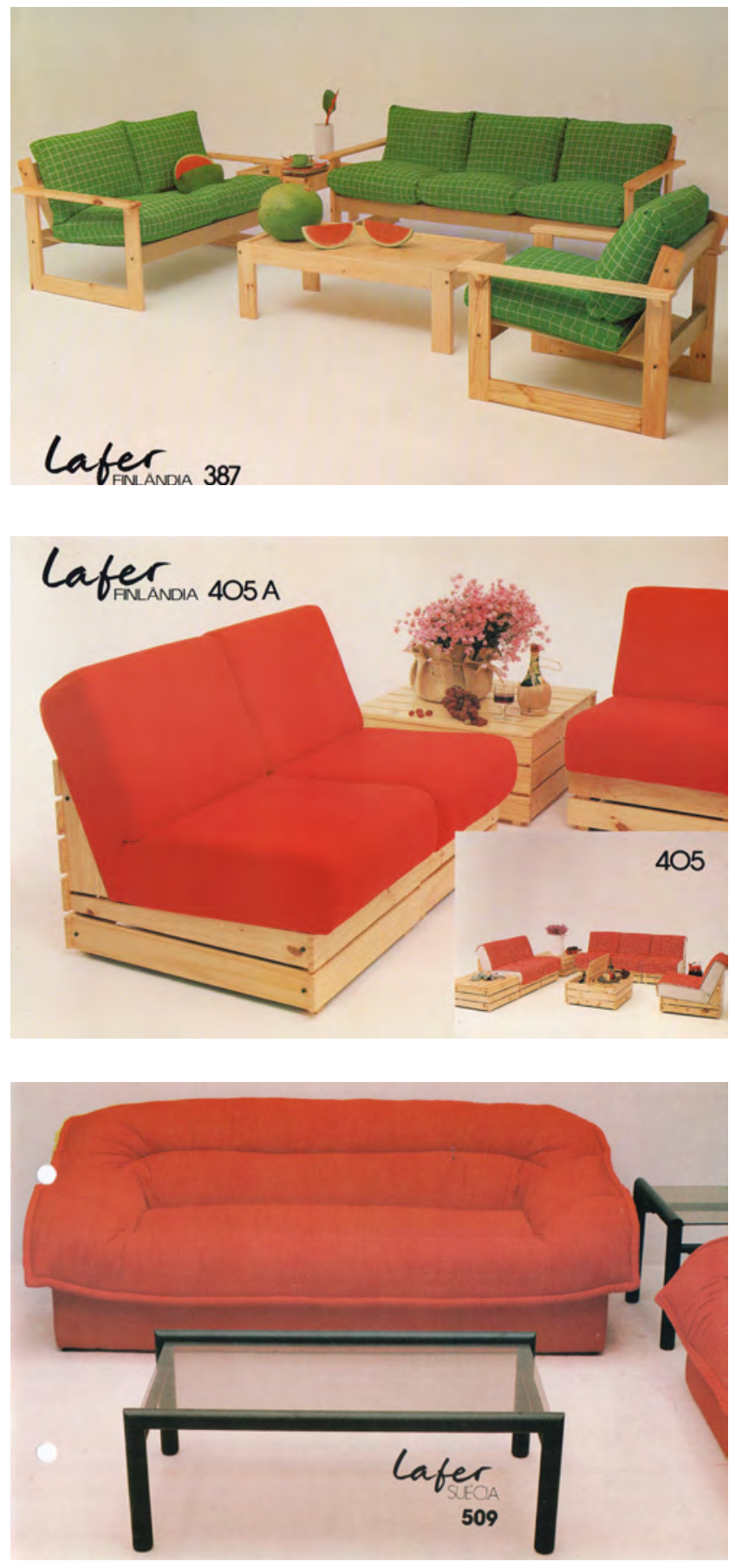

$\oplus$

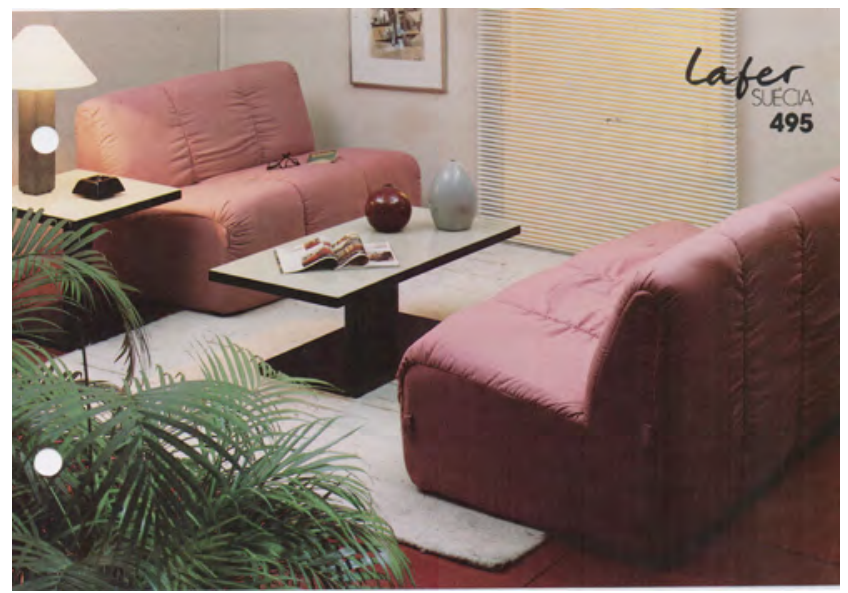




\section{AS RECLINÁVEIS}

No início dos anos 1990, logo após a experiência da recessão econômica no Brasil - conhecida como a década perdida -, a MP Lafer reformulou sua estrutura de funcionamento, adotando políticas de produção e abastecimento mais enxutas. A venda no varejo foi cancelada e parte das lojas próprias foi fechada. O parque industrial foi vendido e a fábrica, transferida para um espaço menor na Vila Prudente, em São Paulo, no ano de 1996. O modelo de exportação foi revisto, e o investimento passou a ser feito apenas para uma linha de produtos, única no mercado: as reclináveis.

Durante os anos precedentes, Percival havia investido grandes esforços na pesquisa de mecanismos e estruturas articuláveis. Na década de 1990, com a encomenda em massa de reclináveis e sofáscamas por diversos setores da área da saúde, houve um impulso maior para o desenvolvimento dessa tipologia de mobiliário. Percival entendeu que o nicho de poltronas reclináveis, bem como de sofás-camas, era um potencial de mercado. Não havia concorrência, a MP Lafer era a única fábrica especializada em oferecer esse tipo de produto. Atualmente, as reclináveis constituem mais da metade do faturamento da empresa, sendo os únicos modelos exportados.

No que diz respeito a base produtiva, houve uma redução considerável de componentes e processos. A madeira deixou de ser utilizada e as estruturas voltaram a ser produzidas apenas em serralheria. A base articulável é a mesma para a maioria das poltronas e sofás, o que facilita a gestão produtiva. As variações entre os modelos são pequenas e podem ser atribuídas à forma do estofado, às função de recline e aos acessórios.

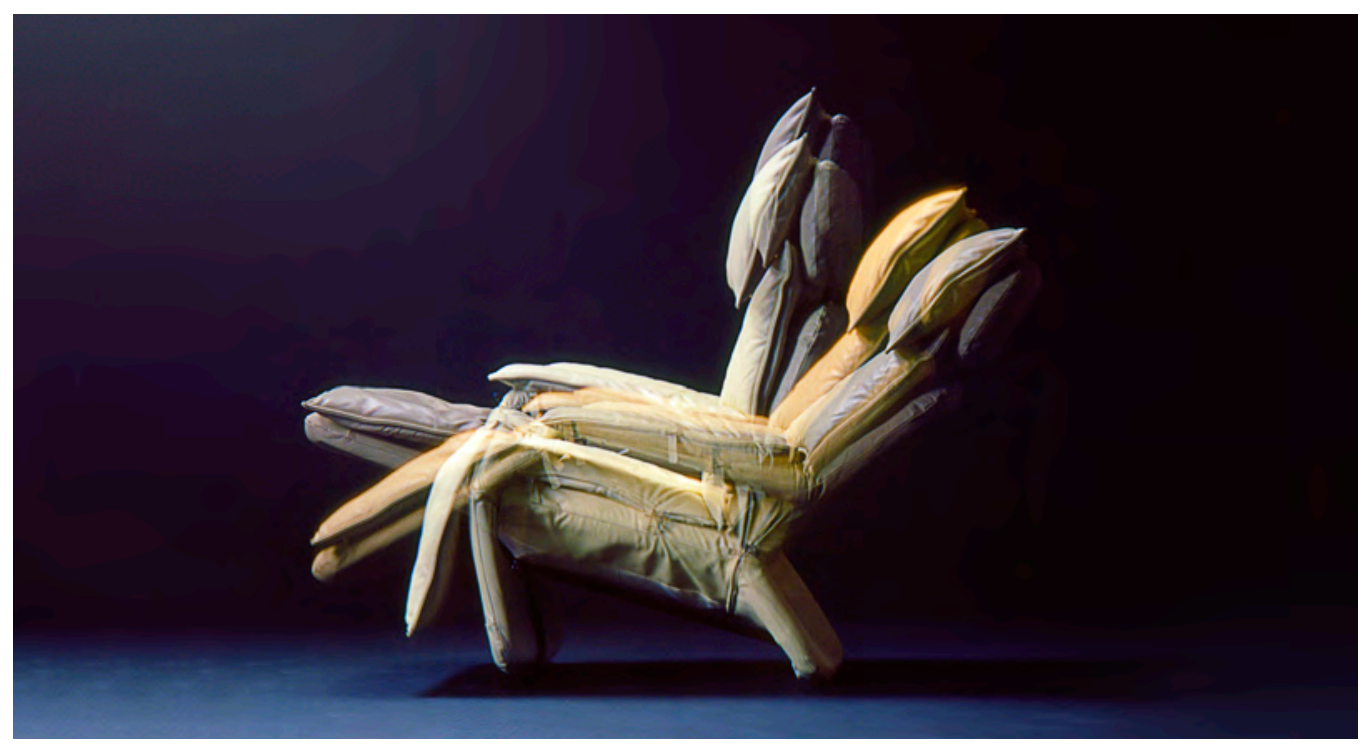

Foto do movimento realizado pela poltrona Pony, primeira reclinável de alta tecnologia da Lafer. 


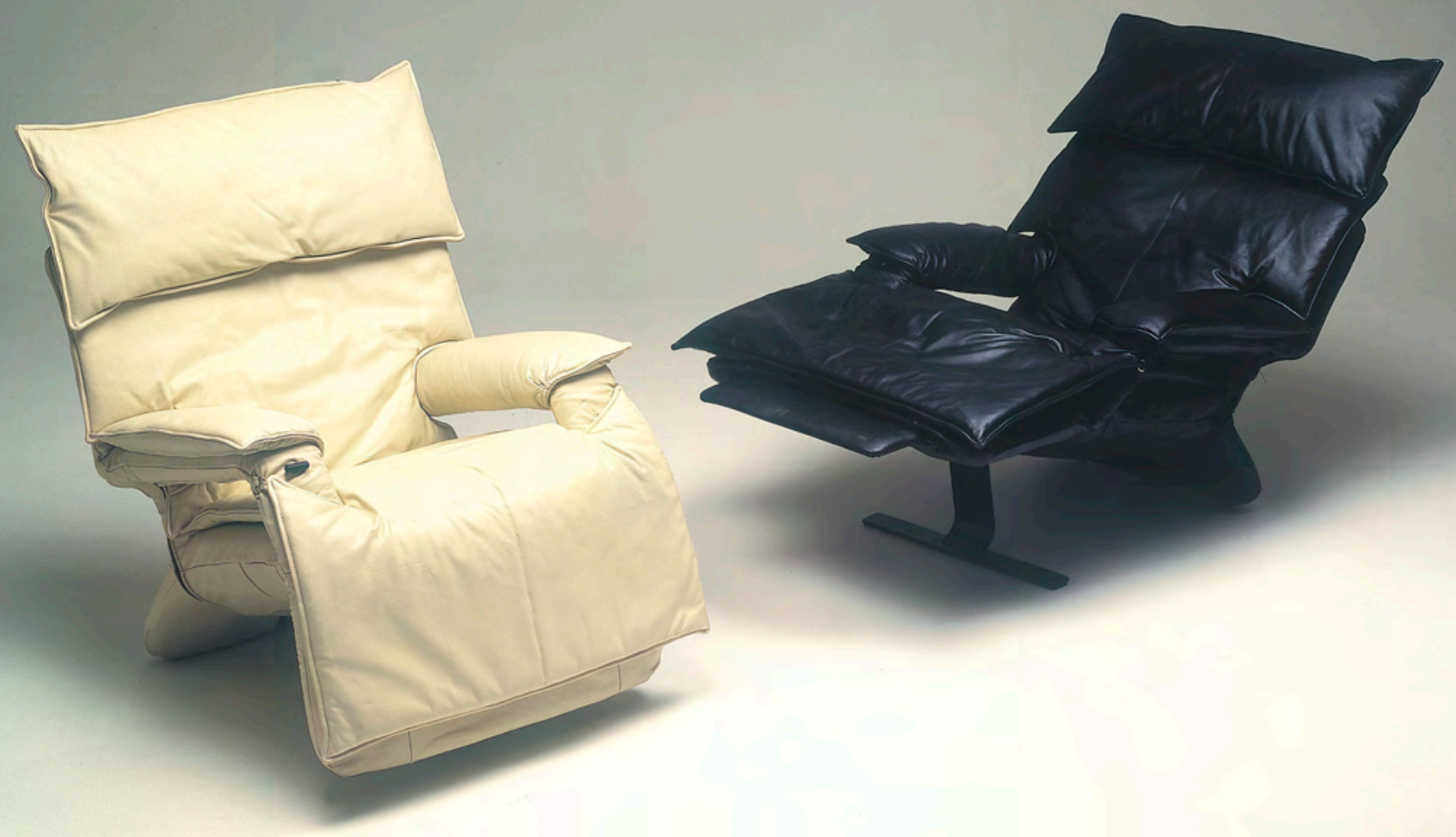

$\oplus$

PONY - 1985

Estrutura articulável da poltrona reclinável Pony

Fonte: arquivo do designer 


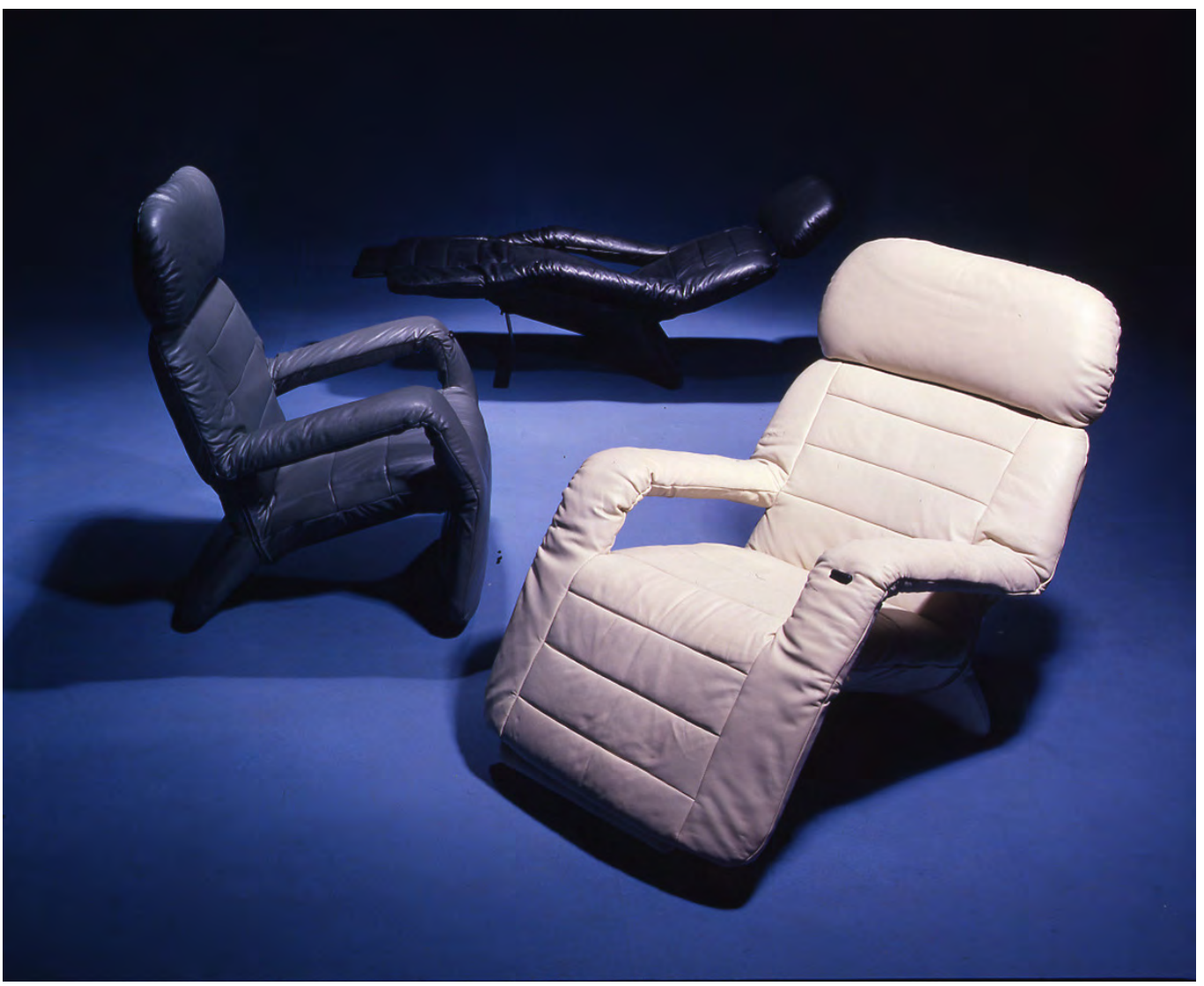

Com mesma

estrutura da Pony, com algumas variações, a poltrona Jet segue o mesmo princípio da anterior.

Fonte: arquivo do designer

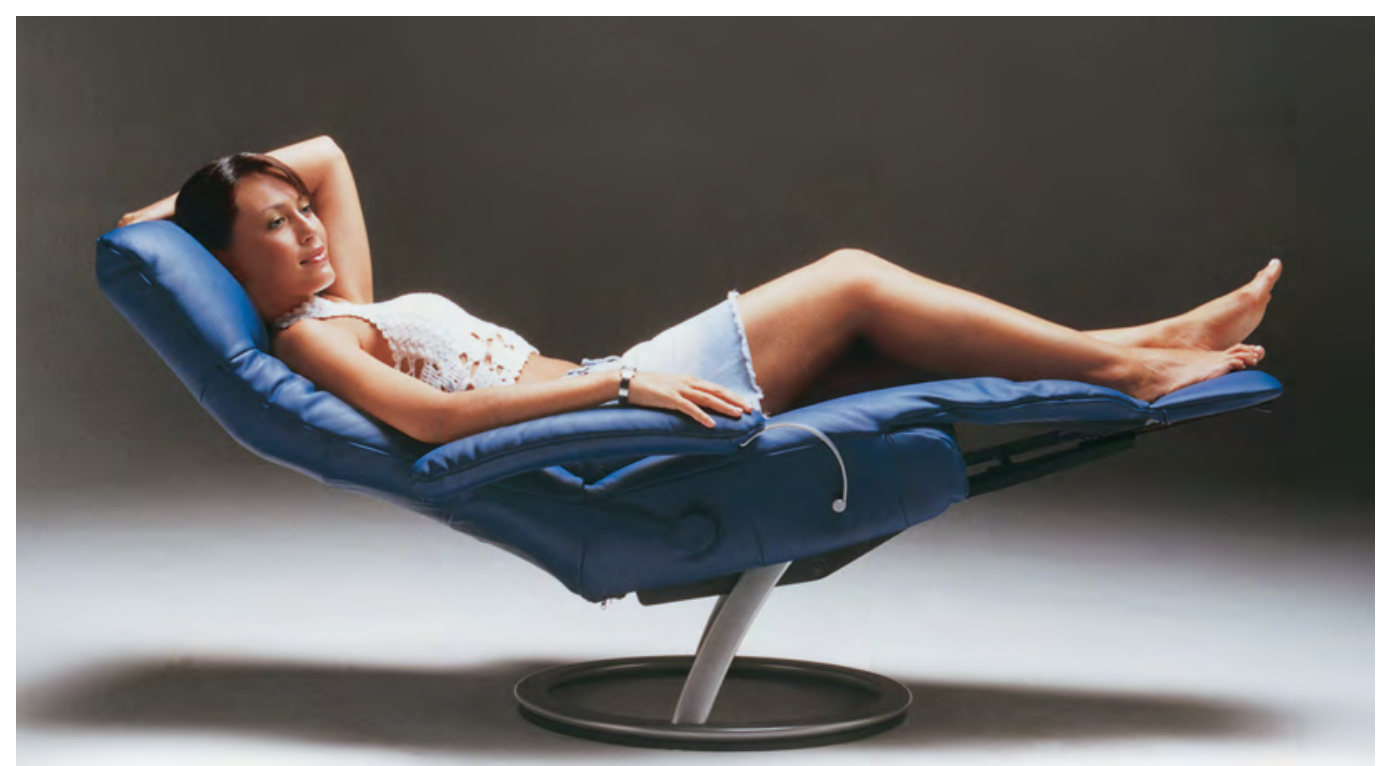

As esruturas foram variadas e acompanharam as tendências exigidas pelo mercado. $\mathrm{O}$ revestimento de couro continua
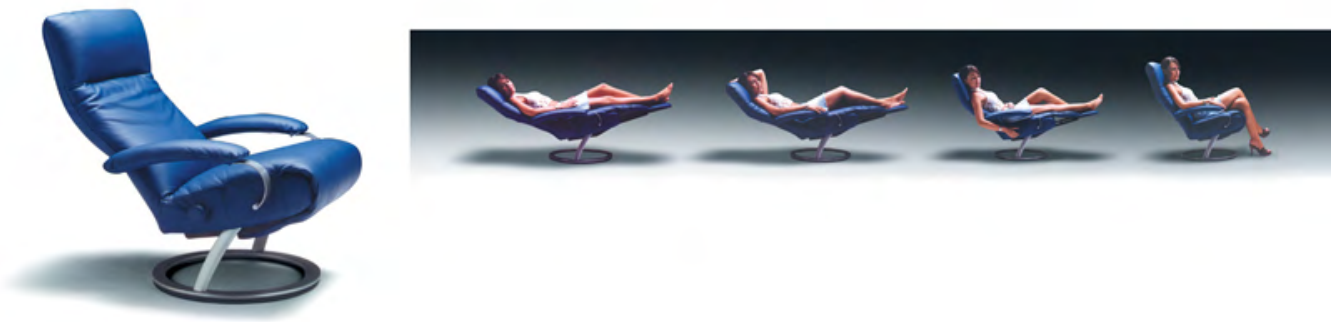
sendo uma tônica na obra de Percival. Aqui, a poltrona Kiri

Fonte: arquivo do designer 



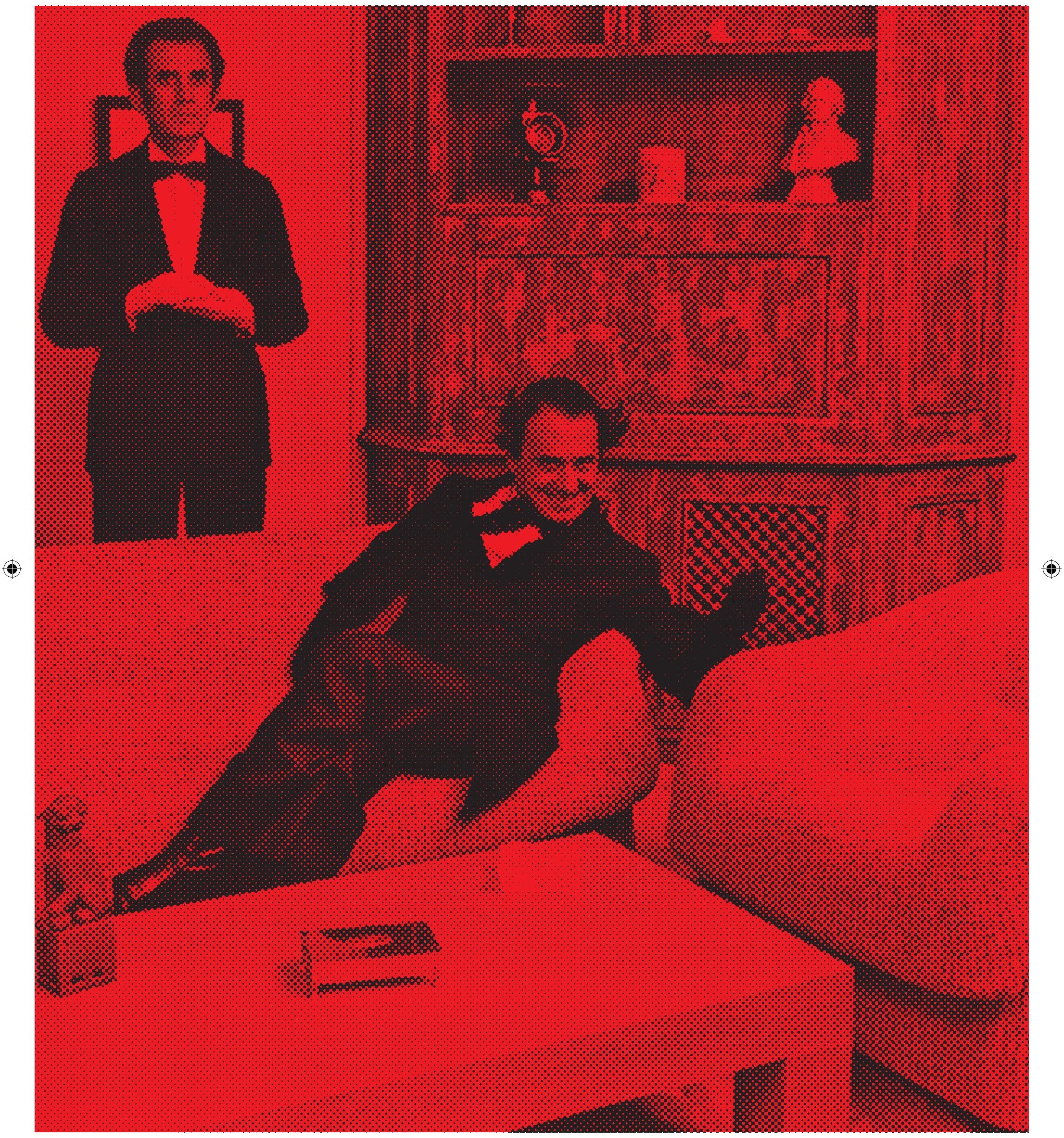




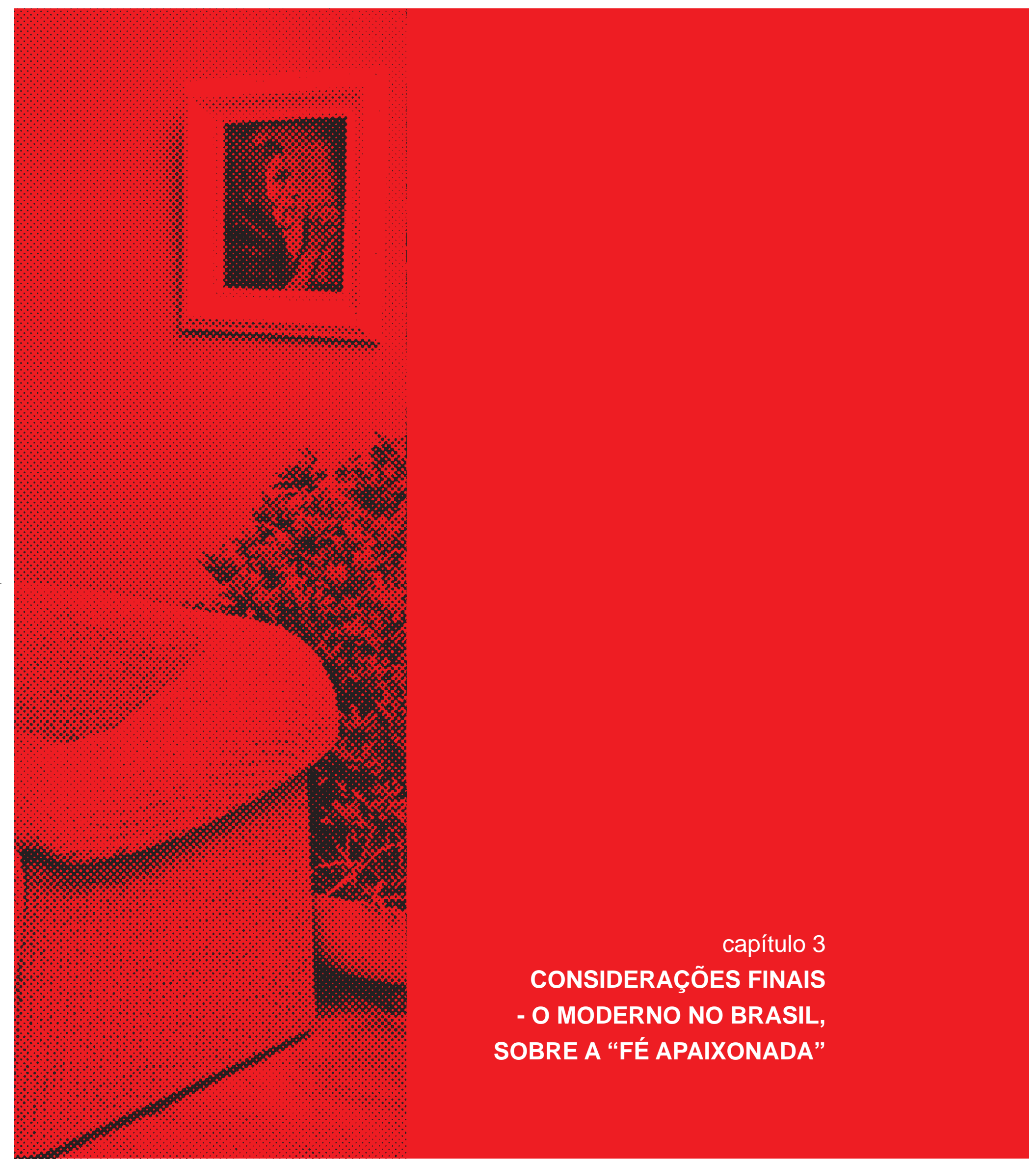

(4) 
Percival Lafer foi um designer de transição. Ele vivenciou a crescente entrada da indústria cultural e de massa no Brasil, e participou de sua disseminação, ao propor uma industrialização que, buscando suas bases nos princípios mecanicistas do movimento moderno, não fez jus ao cerne da questão social do contexto brasileiro. O lema "bom design para todos" não se efetivou. "Todos" eram os pertencentes às classes médias e altas. As urgências populares de combate a pobreza e da liberação humana foram relegadas em prol de um suposto crescimento que, dentro da discursiva burguesa, sempre confunde interesses pessoais e públicos.

Em seu tempo, a propaganda estava começando a ocupar seu lugar de grande poder, bem como o design estava sendo definido enquanto campo de ação para as perspectivas de dominação e direcionamento das massas consumidoras. A ideia moderna europeia, que impregnou 0 exercício da arquitetura e do design modernista brasileiro, não condizia com a realidade nacional. Esquecemos, muitas vezes, que fazia apenas pouco mais de meio século da abolição da escravidão no Brasil, quando os edifícios de Higienópolis ou da zona sul do Rio de Janeiro estavam sendo construídos.

Percival Lafer esteve no interstício do que podemos chamar de últimos suspiros do movimento moderno no Brasil e os diversos que seguem. Sua atuação foi única no país. Percival concatenou variantes de projeto e industrialização, e assim construiu um império, por meio de um pensamento liberalizante. O simples fato da desintegração do trabalho, por meio de sua redução especializada, nos diz muito sobre o preço pago pelo suposto progresso industrial estabelecido no Brasil. As variantes complexas de sabedoria local, bem como a liberdade construtiva de uma industrialização com base em um pensamento autóctone, foram completamente rechaçadas. Lafer consolidou, assim, uma trajetória particular que pode nos dar pistas para reavaliar o real lugar do design enquanto instrumento adequado para o devir humano.

A quem dirigiu-se o discurso altamente carregado de teor social, saído da boca de arquitetos e designers? As camadas populares foram algum dia escutadas? A resposta mais evidente é negativa. Nesse sentido, o caso da industrialização em Percival Lafer, juntamente a outras iniciativas artesanais da época, aponta contundentemente para a transformação esvaziada do sentido e do campo de atuação do design. Sendo assim, mais do que ponderar e criar juízos de valor sobre a obra
Pg. 180 - foto de Agildo Ribeiro, que encarna a personagem

Prof. Mitologia em cenário que utiliza o conjunto MP247.

Fonte: arquivo do designer 
de Percival Lafer, caminho potencialmente reducionista, limbo do elogio infundado ou do negativismo pernicioso, faz-se necessário ponderar, sob a luz do que foi levantado, sobre o papel do design e do designer hoje.

Que o movimento moderno, enquanto tendência e estilo, chegou ao Brasil de forma decantada é um fato. Mario Pedrosa chegou a definir a vontade transformadora de arquitetos e designer modernistas como "fé apaixonada" ${ }^{35}$. No entanto, arquitetura e design serviram apenas para a validação das elites. Fé cega, o sonho não passou do campo do discurso, mantido de forma unilateral e verborrágica. Houve muita fala e pouca escuta, salvo algumas exceções, como por exemplo as escolhas da trajetória de Lina Bo Bardi.

$O$ vazio de questões tem perpassado a produção nacional. O que e a quem de fato se tem produzido? Com quem se tem comunicado? O que foi feito das preocupações sociais dos modernistas? Sobre o que somos responsáveis? Produtores contemporâneos, com sua massa de produtos e ideias ralas, não respondem a essas perguntas. $O$ design continua constituindo um sistema de dominação empenhado em construir um discurso regedor da prática perversa de exclusão.

Entender o pensamento por detrás do fazer design, ou produzir um mundo material com base industrial, nos conduz a outras épocas, tempos anteriores que delinearam a forma de projetar enquanto dinâmica vital, instância esta, atulhada por camadas e mais camadas de discursos, muitas vezes ditos humanistas ou carregados de ideologia pseudosocial. Talvez, nos tempos modernos, com tudo que isso significou na história apenas para citar rapidamente as guerras, genocídios, a pobreza extrema da maior parte da população mundial, a exaustão e mau uso do planeta -, tenha ficado evidente a necessidade de contornar a situação e, dentro do que Foucault identificou como biopolítica do poder, propor novas formas "radicais" de relação entre o humano e o mundo forjado por ele.

Aproposição (o projeto) jamais éisenta. Acomplexa rede de poderes, tecida de modo a garantir a manutenção dos mesmos, está armada há tempos, e, por debaixo dela, se encontra a população mundial. O controle dos corpos, alienados de sua potência individual e desarticulados em sua potência coletiva, mantém a todos como vítimas ao mesmo tempo que agentes do poder que, capilarizado e fundido no que podemos chamar 
genericamente de etos da sociedade capitalista globalizada, extende-se e transforma-se em movimento viral. O achatamento das relações é visível, sejam elas entre próximos, sejam com a realidade farsesca que criamos, ou ainda com o cosmos do qual somos parasitas. A possibilidade da experiência está diminuída, soterrada pelo lixão das certezas, opiniões, disciplinas, objetos, enfim, de todo o peso que o esquecimento da morte nos causa. Afinal de contas, para que tudo isso que nos circunda, senão para nos convencermos da morte, ou melhor dizendo, da não morte?

O design encontra-se hoje no cerne dessas e outras questões relativas ao esvaziamento da vida por meio do controle dos corpos. A existência "designada" tornou-se pauta para o mundo globalizado. Estamos cada vez mais objetivados, e o sentido de design no discurso da cultura atual é hegemônico. Design e poder têm andado de mãos dadas na configuração da promessa cultural. Como Flusser bem coloca, o design tem cumprido seu papel enquanto "propósito" de um "esquema maligno", "conspiração" plena de "astúcia" e "fraude". O filósofo lança a questão: "a quem e ao que enganamos, quando nos inscrevemos na cultura do design?"36. Enquanto discurso e prática se tornam cada vez mais dogmáticos, dimensão do risco ${ }^{37}$ é eliminada, e o design tem sido a principal fer-

36 FLUSSER, Vilém. O mundo codificado. São Paulo: Cosac Naify, 2007.

37 Em belíssimo texto, Jorge Larosa Bondia sublinha a intrínseca relação entre a experiência e o risco. Ele diz: "[...] O sujeito da experiência é um sujeito "ex-posto". Do ponto de vista da experiência, o importante não é nem a posição (nossa maneira de pormos), nem a "o-posição" (nossa maneira de opormos), nem a "im-posição" (nossa maneira de impormos), nem a "pro-posição" (nossa maneira de propormos), mas a "exposição", nossa maneira de "ex-pormos", com tudo o que isso tem de vulnerabilidade e de risco. Por isso é incapaz de experiência aquele que se põe, ou se opõe, ou se impõe, ou se propõe, mas não se "ex-põe". É incapaz de experiência aquele a quem nada the passa, a quem nada lhe acontece, a quem nada lhe sucede, a quem nada o toca, nada Ihe chega, nada o afeta, a quem nada o ameaça, a quem nada ocorre. Vamos agora ao que nos ensina a própria palavra experiência. A palavra experiência vem do latim experiri, provar (experimentar). A experiência é em primeiro lugar um encontro ou uma relação com algo que se experimenta, que se prova. O radical é periri, que se encontra também em periculum, perigo. A raiz indo-europeia é per, com a qual se relaciona antes de tudo a ideia de travessia, e secundariamente a ideia de prova. Em grego, há numerosos derivados dessa raiz que marcam a travessia, o percorrido, a passagem: peirô, atravessar; pera, mais além; peraô, passar através; perainô, ir até o fim; peras, limite. Em nossas línguas há uma bela palavra que tem esse per grego de travessia: a palavra peiratês, pirata. O sujeito da experiência tem algo desse ser fascinante que se expõe atraves- 
ramenta de imobilização e desarticulação de potências transformadoras.

A abundância de projetos e mediações achatou os valores de vida e morte. No caso da arquitetura e do design, profissionais ocupam-se em, discursivamente, delinear um ideal de comportamento e de vida coletivo, mas, por não escutar, desconsideram a complexidade plural da situação brasileira frente ao processo internacional de globalização. O "truque" virou uma prisão, por meio de "promessas que não se cumprem" ${ }^{38}$. A trapaça tornou-se autoengano.

Ora, a faca que corta o pão também fura a carne. Não tem havido precisão no uso do design enquanto instrumento de transformação social. São poucas e pequenas as iniciativas que têm se ocupado das mazelas que a maior parte da população mundial tem sofrido. A abundância material e afogamento da vida pelo consumo também são uma grande mazela, e é dentro do desequilíbrio entre a riqueza e miséria extremas que o design tem desenvolvido sua atividade. Antes da definição do "melhor formato para a sala de jantar", o problema do que colocar sobre a mesa permanece. Para aqueles que fazem design e o consomem, talvez tenha faltado essa instância essencial de sobrevivência.

A falta de foco sobre os reais problemas é o que pautou a produção do mundo material até aqui. Profissionais formados nas mais diversas universidades procuram sua especialização para servir a indústria e ao próprio ego, esquecendo de que o projeto material deve estar alinhado às reais necessidades para que possa ter profundidade de sentido e transformação. Não há sentido de urgência. Um exemplo que clarifica essa realidade são os mercados. Os mercados populares de cidades onde a relação com o local ainda é presente são uma fonte de produtos

sando um espaço indeterminado e perigoso, pondo-se nele à prova e buscando nele sua oportunidade, sua ocasião. A palavra experiência tem o ex de exterior, de estrangeiro, de exílio, de estranho e também o ex de existência. A experiência é a passagem da existência, a passagem de um ser que não tem essência ou razão ou fundamento, mas que simplesmente "ex-iste" de uma forma sempre singular, finita, imanente, contingente. Em alemão, experiência é Erfahrung que contém o fahren de viajar. E do antigo alto-alemão fara também deriva Gefahr, perigo, e gefährden, pôr em perigo. Tanto nas línguas germânicas como nas latinas, a palavra experiência contém inseparavelmente a dimensão de travessia e perigo." BONDIA, Jorge Larosa. Notas sobre a experiência e o saber da experiência. In: abril de 2002 no. 19. 
e materiais que suprem de forma precisa as necessidades urgentes e reais da comunidade. Da comida a panelas, de cestas ao vestuário - tudo tem ali o seu lugar. Produtores locais fornecem produtos resolvidos em sua forma e função (função estética inclusive, de maneira exímia). Shopping Centers, lojas de departamento, mercados da escala global apenas criam mais necessidades ao invés de supri-las. O balanço entre essas duas formas de comércio revela o que há por detrás de dois posicionamentos opostos em relação à projeto e produção. Tudo é uma questão de escala e propriedade do lugar.

Não há como desvincular esse desequilíbrio aos valores contemporâneos do trabalho, que objetifica a atividade humana dentro da dinâmica liberal de acúmulo e compreensão da riqueza (riqueza é um valor efêmero e subjetivo, que tem sido definido com uma certeza estratégica e dominadora); ao entendimento tanto por parte do poder, como por parte das massas, do que consiste a esfera pública de atuação, bem como a delimitação de seu espaço; às noções de conforto, necessidade e urgência. Não nos ateremos a essas definições, no entanto, faz-se necessário apenas sinalizar a ligação existente entre elas, para maior compreensão do como o design em sua dinâmica produtiva se consolida enquanto modelo.

O móvel brasileiro, com raras exceções experimentais, tentou atender a massa de fato. A população miserável nem sequer foi levada em conta nesses exercícios, e por isso, em suas tentativas, esbarram rapidamente no limite de análise sobre a real necessidade da população brasileira, que é comer, antes de sentar à mesa. A dimensão social do sentar à mesa foi e é privilégio de poucos, e não pode configurar a preocupação de profissionais de um campo inteiro. Ao que se dá isso, senão a uma deturpação estratégica, classista e irresponsável dos envolvidos em pensar o suprimento material básico humano para a vida?

Encarar o truque do design de frente, relacionando-o à responsabilidade de desativar as estruturas centenárias que têm mantido o poder na mão de tão poucos, faz-se necessário para criar novas possibilidades para que a experiência humana se instaure. É preciso pulverizar o poder. Qual será o truque para isso? Certamente não virá das visões esotéricas e autoritárias da maioria dos designers envolvidos em alimentar e conduzir a indústria cultural do capital. Não virá de poltronas e sofás ou qualquer outra variação estilística sobre o mesmo tema. Lina Bo Bardi, em seu livro Tempos de Grossura - O Design no impasse citando Brecht, fala sobre o poder transformador que reside no balanço entre o direito de dizer sim e o direito de dizer não. O que significaria dizer não? 


\section{DESIGN HOJE - A VENDA DE MODOS E MODAS E O PROJETO DA OBSOLECÊNCIA}

"Sede não é nada, imagem é tudo." 39

São inúmeras as definições de design que podem ser usadas para o estudo do mesmo, e é sinuoso o caminho do reducionismo. É por isso que não vamos, aqui, entrar nos meandros pedregosos da definição. O presente ensaio não tem como objetivo definir o que é design, mas ponderar sobre a atuação social do que hoje é considerado mercadoria de design. A partir de uma análise baseada em diversas obras de pensadores do design, tiramos algumas diretrizes que a objetivam. Não pretendemos encerrar o conceito de design a uma única forma de produção. Quando falamos em design, pensamos em produção industrial, já que a disciplina foi alçada especialmente por esse campo. No entanto, buscamos compreender conceitos que transcendessem esse tipo de classificação, mesmo porque o advento do design, hoje, ultrapassa, de certa forma, a produção industrial, inundando esferas materiais e simbólicas do fazer humano. Pretendemos, acima de tudo, estabelecer uma relação entre o que hoje é considerado design e o papel social que ele desempenha. O design ao qual nos referimos concerne a todo aparato para o desenvolvimento da vida cotidiana - dotado de um valor subjetivo e arbitrário, e que alimenta o mercado de consumo conspícuo. Tratam-se dos "produtos" e "objetos" que, na sua maioria, carecem de profundidade e utilidade real, e que carregam o status de design como caráter distintivo. Os termos "produto" e "objeto" serão utilizados em sua forma mais aberta, determinando tudo aquilo que o discurso sobre o design toca enquanto retórica.

O largo uso mundial da palavra inglesa design é de âmbito contemporâneo. Aqui, esse termo nomeia uma faceta muito específica da produção material e intelectual da atualidade. Tanto é assim que, no Brasil, os antigos cursos de "Desenho Industrial" passaram a se chamar "Design". Pode-se dizer que o uso dessa palavra advém da hegemonia da máquina e sua produtibilidade e, ultimamente, sobretudo, sob o

39 Trocadilho popular feito a partir de uma propaganda de refrigerante que dizia: "Imagem não é nada, sede é tudo. Obedeça sua sede!". No contexto midiático, esse slogan é contraditório e paradoxal. Pode-se dizer, que ele age por efeito contrário à mensagem. 
signo da liquidez do capital. Com o passar dos anos e da evolução do sistema industrial baseado nos preceitos neoliberais, a palavra design transformou-se e ganhou muitos outros significados, além de projeto e produto industrial. Hoje, ela determina uma série de valores complexos e latentes que englobam o status, poder, riqueza e obsolescência.

$\mathrm{O}$ projeto humanista que antes permeava de certa forma $\mathrm{O}$ pensamento moderno do design foi relegado a outro plano. Todas as teorias e correntes artísticas que consideraram e pregaram o design como uma medida para a humanização do mundo, ferramenta de um novo tipo de sociabilidade, tais como a Art Nouveau, a Bauhaus, entre outras, foram ultrapassadas. O design passou a personificar a própria ferramenta para a exclusão. O processo de projeto industrial entrou finalmente no sistema de moda, em que os ganhos são medidos pelo grau de obsolescência e efemeridade do produto, além da distinção que ele aporta. Como tudo o que apresenta resistência, a disciplina do design também foi, senão inteira, em parte, engolida pelos sistemas de produção e ganho capitalista.

Com o tempo, o desenvolvimento de projeto foi modificado em sua essência para corresponder e gerar novas necessidades. $O$ objeto passou a ser imagem. $O$ design deixou de ser a resolução da necessidade para ser necessidade delirante. Consolidou-se um código cheio de signos, que paradoxalmente distinguem, inserem e uniformizam, segundo os padrões da sociedade oficial. Nesse sentido, perdeu-se muito do campo de atuação do designer - no que se refere a ação de resolver equilibradamente problemas urgentes e elementares para a perpetuação da humanidade.

Dessa maneira, pode-se dizer que o design e seus produtos foram engolidos pela dinâmica capitalista como mais um meio de perpetuá-la. A cada dia que passa, os objetos e aspectos vitais precisam adquirir novas formas e aspectos para produzirem novos ganhos. Busca-se incessantemente inventar novas necessidades (que de necessárias não têm nada) para impulsionar a economia dos lucros, já que se não mudar a função e a forma, o ganho também não muda. A necessidade real não condiz com a ganância de industriais e criadores. A própria necessidade precisa ser reinventada dia a dia, sempre num movimento de satisfação total e distinção daquele que compra. O consumidor, por sua vez, é engolido pelas relações egóicas que os objetos estabelecem no que diz respeito a status 
e poder.40 A dinâmica do projeto funciona de forma vampiresca.

Neste ponto, pode-se fazer um escrutínio sobre o nosso posicionamento como designers. Será que estamos envolvidos em produzir sem profundidade, seja ela formal, ideológica ou poética? Este ensaio visa colocar em questão o que hoje é tido como design e como ele configura uma maneira de destruição da cultura e canibalização do meio-ambiente natural.

Essa análise apoia-se diretamente sobre a teoria da mercantilização da cultura e das rendas de monopólio formulada por David Harvey. Essa proposta analisa um processo maior, que engloba a produção de objetos, de espaços, das cidades, possibilitando-nos compreender as forças envolvidas e suas resultantes. Contribui, também, para a compreensão de como o projeto vernacular é inserido em tal contexto como um movimento de real e eficaz resistência.

Harvey começa situando a renda de monopólio como um dos grandes interesses do capitalismo neste mundo globalizado. Segundo o autor, num primeiro momento, devido à dinâmica de acumulação e resolução de crises, o capitalismo tenta diminuir ao máximo a diversidade espacial. Ao mesmo tempo, ele necessita gerar espaços não iguais que criem bases para diversas possibilidades de renda e acumulação baseada na distinção. Um dos exemplos mais flagrantes dessa dinâmica é a relação centro-periferia. Entre outras, é umas das maneiras que o capitalismo encontra para acumular mais e mais e fluidificar o movimento do capital.

Em sua teoria, Harvey explicita a lógica do acúmulo, por meio da renda de monopólio. A partir da ideia de que o capitalismo é uma forma de espaço e de espacializar, o autor explica como a cultura virou, hoje, um canal para a criação retórica de mercadorias ímpares, numa dinâmica de especulação. Inserido no processo de globalização econômica, o capital precisa achar novos meios de conquistar fontes de renda que sejam monopólios. Para tanto, no campo da cultura, utiliza-se do discurso. Um exemplo dado por Harvey é a venda de obras de arte. Os valores são atribuídos por uma série de qualidades especulativas como unicidade, exclusividade etc. No caso do turismo, por exemplo, uma determinada

40 Essa dinâmica de poder faz parte da confusão criada em torno do limite da atuação individual na sociedade pública, sobretudo, no meio urbano. Isso se reflete diretamente sobre o tratamento recebido pelos necessitados e sobre os abusos que sofrem. 
área pode ser descrita como pura, selvagem, exótica, para atrair o capital daqueles que querem beneficiar-se dessas falácias. No entanto, existe um paradoxo. Ao mesmo tempo que essa lógica capitalista atribui qualidades tidas como inigualáveis aos objetos e coisas que se quer vender, pressupõe que nada é tão especial e único assim, que o valor monetário não the possa ser atribuído. No final, tudo se compra, até mesmo, a arte. Isso tem gerado a destruição do que, em certa medida de verdade, é único, para que possa ser comercializado. O autor diz:

“(...) se a pretensão à unicidade, à autenticidade, à particularidade e à singularidade sustém a capacidade de captar rendas de monopólios, podemos então imaginar terreno mais propício que o campo historicamente constituído dos objetos e práticas culturais, ou que o domínio de características ambientais específicas (o que recobre, bem entendido, os contextos edificados, sociais e culturais)? (...) todas essas pretensões resultam em construções e lutas discursivas, e se fundem em fatos materiais. Muito repousa sobre narrativas históricas, sobre interpretações e sentidos construídos dentro da memória coletiva, sobre significados inerentes às praticas culturais e sobre coisas da mesma natureza: um elemento social e discursivo forte está sempre em obras na construção de suas pretensões. Uma vez estabelecidas, todavia, estas podem servir à extrair rendas de monopólio já que, ao menos dentro de nosso espírito cidades como Londres, Cairo, Barcelona, Milão, Istambul, ou São Francisco, possuem um caráter único absolutamente não achado em nenhuma outra parte." 41

Pode-se substituir os nomes das cidades citadas por Harvey por nomes de objetos, marcas ou diversos designers. Entende-se de maneira clara como o design foi transformado, mais do que nunca, em fonte de renda e manipulação. A necessidade, a profundidade do projeto, a poética, em si, deixaram de ser prioridades, desde que os quesitos de exclusividade e distinção instiguem o esquema de compra e acumulação. No processo criativo, essas qualidades e "pretensões" tornaram-se, historicamente, partes fundantes do conceito do objeto: existentes já na raiz da criação. O objeto de design, neste caso, já nasce significando o

41 Harvey, David. Geographie de la domination. Editions les Prairies Ordinaires. Paris, 2008. pg. 44. 
que quer que seja, desde que se consolide nele uma forma de distinção e mais de renda monopólio. É o caso da arquitetura ícone criada na maioria das nações aspirantes a alguma coisa hoje. Harvey diz:

“ (...) a luta pelo capital simbólico coletivo ganhou em importância como base de rendas de monopólio. Como explicar outramente o grande interesse suscitado pelo Museu Guggenheim de Bilbao, com sua arquitetura assinada Gehry?"

Como explicar então todo o resto do aparato material midiatizado e sem profundidade? A resposta é a mesma: dentro de um contexto maior, o objetivo é o lucro e o acúmulo, delirante. Hal Foster diz a respeito do Museu Guggenheim, em Bilbao, e à atuação de seu arquiteto:

“...seus clientes desejam ardentemente otimizar seu capital de marca no mercado globalizado. Guggenheim virou uma marca que se vende a empresas e governos - e esta situação favoreceu o arquiteto, que pode fornecer um edifício suscetível de ser difundido na mídia como um logo. (É exatamente assim que Bilbao utiliza o museu. O Guggenheim é o primeiro logo da cidade visível da rua, e ele permitiu Bilbao de existir enfim sobre os mapas de turismo mundiais." 42

Harvey observa muito bem que essa dinâmica toda se fundamenta sobre o discurso, ou seja, a publicidade. Ele salienta:

“(...) precisa-se invocar outros modos de distinção a fim de legitimar as pretensões e o discurso "monopolístico" visando garantir a verdade dessas pretensões." 43

Ainda segue:

"A generalidade de um mercado globalizado produz (...) uma força poderosa que procura garantir não somente a perpetuação dos privilégios de monopólio da propriedade privada como também op. Cit. 
renda de monopólio decorrente das mercadorias descritas como incomparáveis." ${ }^{4}$

Dentro dessa mesma lógica de atribuição arbitrária de valor, Marilena Chauí fala sobre uma sociedade que se alimenta de imagens fugazes e intercambiáveis, num movimento que tem o mundo da moda como paradigma de sistema. Nesse sentido, ela enfatiza o que é colocado por Harvey e ainda acrescenta a característica de fugacidade à dinâmica apresentada. O discurso é a imagem. A imagem estabelece as ligações qualitativas daquilo que é consumido num processo retroativo, no sentido em que o próprio discurso, representado por Chauí pelos domínios da "propaganda e marketing", também faz a imagem. Imagem e discurso retórico revezam-se na consolidação da estrutura do consumo. Ela diz:

“(...) as novas tecnologias deram origem a um tipo novo de publicidade e marketing, no qual não se vendem e compram mercadorias, mas o símbolo delas, isto é, vendem-se e compram-se imagens que, por serem efêmeras, precisam ser substituídas rapidamente. Dessa maneira, o paradigma do consumo tornou-se o mercado da moda." 45

É explícito o caráter destrutivo dessa dinâmica. Nota-se que a espiritualidade das coisas e dos seres deu lugar ao consumismo de modos e modas, no desenvolvimento de um fenômeno social de descaracterização da identidade do indivíduo e da cultura. Hal Foster fala sobre a lógica narcisista da moda e da imagem:

“...o design é também um dos principais agentes que nos encerra dentro do sistema quasi-total do consumismo contemporâneo. O design é primeiramente e, antes de tudo, um caso de desejo, mas este desejo, estranhamente, parece quase sem sujeito, ou ao menos sem falta; ele parece promover um novo tipo de narcisismo, todo imagem e desprovido de interioridade. E essa apoteose do sujeito anuncia também sua desaparição." ${ }^{46}$ 
Neste contexto, qual é o lugar da população pobre das grandes cidades? A resposta é muito simples. Não é tudo que se encaixa nas definições de "único" ou "puro" para venda. Além disso, o ritmo de mudança do "novo" é muito rápido. O design posto em prática hoje só funciona na base da exclusão. Para que exista acúmulo para alguns, a falta para outros é necessária. Uma base social igualitária não possibilita a renda de monopólio. Assim sendo, a rejeição tanto da matéria como da população é algo inerente a essa dinâmica.

Na sua conclusão, Harvey apresenta pontos importantes, descritos como esperanças. Ele diz que a luta não deve ser dirigida contra o fantasma do grande capital, mas deve pretender arrancar os espaços locais das mãos dos capitalistas.

Nesse contexto, como o objeto e a criação vernacular são uma brecha na especulação de renda e acúmulo?

Alguns pontos importantes são que ele é, primeiramente, anônimo, na medida em que é propriedade de uma coletividade. Em segundo, está sempre mudando conforme as necessidades existentes. Além disso, é uma iniciativa individual. É a questão do faça você mesmo. Dessa forma, não se compra o especial, puro e único, mas se produz. É uma questão de vida.

Outro fator que demonstra o valor das iniciativas populares é que

seu texto 'Pourquoi tout n'a-t-il pás déjà disparu?' diz: "De fato, o sujeito se perde - o sujeito como instância de vontade, de liberdade, de representação, o sujeito do poder, do saber, da história, este desaparece, deixando atrás de si, seu espectro, seu duplo narcísico. Ele desaparece por uma subjetividade difusa, flutuante e sem substância ectoplasma que envolve tudo, e transforma tudo em imensa superfície de reverberação de uma consciência vazia, desencarnada - todas as coisas radiando de uma subjetividade sem objetivo -, cada átomo (aqui Baudrillard utiliza a palavra monade, referindo-se ao conceito de substância simples e única, fundamental na filosofia de Leibniz), cada molécula presa nas malhas de um narcisismo definitivo, de um "retorno-imagem" perpétuo." Neste texto, o autor, falando de fotografia, relaciona interessantemente a imagem a desaparição do sujeito, não na "transmutação virtual das coisas", mas como diz Baudrillard, na "divisão infinita do sujeito, de uma pulverização em cadeia de todos os interstícios da realidade". Ora é nessa lógica de "subjetividade difusa e flutuante" que o impulso criador de design é baseado atualmente, bem como todo desenvolvimento técnico alienante. (T.d.a.). Foster, Hal. op. Cit. 
elas habitam o sistema ao qual resistem. Harvey diz que a saída é o domínio e apropriação do capital pela cultura e não o contrário, que vem acontecendo. Ele conclui:

"Procurando explorar esses valores que são a autenticidade, o local, a história, a cultura, a memória coletiva e a tradição, eles (os capitalistas) abrem um espaço propício ao pensamento político e à ação, um espaço onde se pode conceber e perseguir alternativas. É esse espaço que os movimentos contestadores devem intensamente explorar e cultivar. É um dos principais espaços de esperança abertos à construção de uma globalização alternativa. Uma globalização em que as forças progressistas da Cultura se apropriem do capital, e não o inverso." 47

Dentro da própria exclusão, que faz parte do movimento monetário e do acúmulo, surge a solução. Isso pode significar a nova estrutura para mudança. A cultura como o centro, ocupando o lugar do capital, na produção de obras, objetos ou o que quer que seja, verdadeiramente únicos e diversificados, dentro de uma lógica de inserção, onde cada um seria e teria sua importância como criador de conhecimento. Do ato passivo da compra, ao ato ativo de criar. De um sistema fechado de fins únicos, nasce outro - aberto de fins múltiplos. 


\section{BIBLIOGRAFIA}

ADORNO, Theodor W. Notas de Literatura I. São Paulo: Editora 34, 2012.

. Indústria Cultural e Sociedade. São Paulo: Paz e Terra, 2015.

BACHELARD, Gaston. A poética do espaço. São Paulo: Martins Fontes, 1993.

BANHAM, Reyner. Teoria e projeto na primeira era da máquina. São Paulo: Perspectiva, 2003.

BARDI, Lina Bo. Tempos de grossura - o design no impasse. São Paulo: Instituto Lina Bo e P.M. Bardi, 1996.

BAUDRILLARD, Jean .Le système des objets. Paris: Editions Gallimard I, 2007.

. Tela Total. São Paulo: Sulina, 2005.

. La societé de consomation. Paris: Folio, 2008.

. Pourquoi tout n'a t'il pas dejà disparu? Paris: Editions de l'Herne, 2007.

BONSIEPE, Gui. Design, Cultura e Sociedade. São Paulo: Blucher, 2011.

. The Uneasy Relationship between Design and Design Research. In: MICHEL, Ralf

(org.). Design Research Now: Essays and Selected Projects. Berlin: Birkhäuser, 2007, p. 25-39.

CHAUÍ, Marilena. Brasil - Mito fundador e sociedade autoritária. São Paulo: Perseu Abramo, 2007.

. Cultura e democracia - O discurso competente e outra falas. São Paulo: Cortez, 2007.

. Escritos sobre a Universidade. São Paulo: Editora Unesp, 2000.

DAVIS, Mike. Le pire des mondes possibles - de l'explosion urbaine au bidonville globale. Paris : Editions La Découverte, 2006.

DRAIBE, Sonia. Rumos e Metamorfoses- Estado e industrialização no Brasil 1930-1960. Rio de Janeiro: Guerra e Paz, 1995.

FURTADO, Celso. Formação econômica do Brasil. São Paulo: Cia das Letras, 2007. 
FLUSSER, Vilém. O mundo codificado. São Paulo: Cosac Naify, 2007.

FOSTER, Hal. Design \& Crime. Paris: Les prairies ordinaires, 2008.

HARVEY, David. Geographie de la domination. Editions les Prairies Ordinaires. Paris, 2008

LEON, Ethel (org). Michel arnoult, design e utopia - móveis em série para todos. São Paulo: SESC, 2016.

LIPOVETSKY, Gilles. Da leveza, rumo a uma civilização sem peso. São Paulo Amarilys, 2016.

LUKÁCS, Georg. A alma e as formas. São Paulo: Autêntica, 2015.

MONTANER, Josep Maria. A modernidade superada - Ensaios sobre arquitetura contemporânea. Barcelona: Gustavo Gili, 2013.

. Depois do movimento moderno - Arquitetura da segunda metade do século XX. Barcelona: Gustavo Gili, 2001.

ROSSETTI, Eduardo Pierrotti. 1964-85 - Arquitetura brasileira em transe. Vitruvius, São Paulo, abril de 2004. Disponível em <http://www.vitruvius.com.br/revistas/read/arquitextos/14.167/5183>. Acesso em: 10 de julho de 2017.

RUBINO, Silvana e GRINNOVER, Marina (org.). Lina por escrito - textos escolhidos de Lina Bo Bardi. São Paulo: Cosac Naify:2009.

SANTOS, Maria Cecília Loschiavo dos. Móvel moderno no Brasil. São Paulo: Olhares, 2015.

Jorge Zalszupin - Design Moderno no Brasil. São Paulo: Olhares, 2014.

PEDROSA, Mário. Arquitetura, ensaios críticos. São Paulo: Cosac Naify, 2015.

TAFURI, Manfredo. Projecto e Utopia - Arquitectura e desenvolvimento do capitalismo. Lisboa: Editorial Presença, 1985.

TIBURI, Márcia. O Design é o destino. Revista Cult, São Paulo, n.204, pg. 21, Agosto de 2015.

Rídiculo Político - uma investigação sobre o risível, a maniulação da imagem e o esteticamente correto. São Paulo:Record, 2017. 


\title{
APÊNDICE 1 - MEMORIAL DESCRITIVO ORELHÃO - CHU MING SILVEIRA
}

\author{
O problema
}

Encontrar uma solução, em termos de design e acústica para protetores de telefones públicos, que apresente uma relação custo-performance melhor que a dos já existentes e que se adequem às condições ambientais.

As soluções existentes

1.Telefones sem nenhuma proteção, simplesmente instalados em paredes de bares, farmácias etc;

2. Telefones em postos de serviços localizadas em edifícios e praças, de forma concentrada.

Estas soluções carregam em si uma série de inconveniências para o usuário e não atendem ao público em geral.

Os projetos (o ovo, a origem)

Com o objetivo de encontrar uma solução inteiramente nova, fizemos uma pesquisa sobre os materiais existentes e respectivas técnicas de execução. Escolhemos o acrílico e o fiberglass pelo fato de suas qualidades atenderem aos requisitos propostos.

Foram realizados estudos para três classes do problema: solução para ambientes fechados (o orelhinha), solução para ambientes semiabertos (as conchas, principalmente para postos de gasolina) e solução para ambientes abertos (os orelhões modulares para logradouros públicos de um modo geral).

Primeiramente foi elaborado o projeto orelhinha, cujas dimensões são relativamente pequenas devido às limitações do espaço para qual se destinam.

A ideia surgiu em princípios de 1970 e, por diversas razões, o primeiro protótipo em acrílico de 6 mm de espessura só foi executado em meados de 1971 e colocado em testes pela então C.T.B., no saguão do seu edifício sede, onde, até hoje, está em perfeita condição de uso. O orelhinha foi projetado para ser fixado em paredes e em pequenos postes, podendo, contudo, ser adaptado a muitos outros tipos de suporte.

Sua forma oval foi adotada não só por suas características acústicas e de design, bem como pela sua 
coerência com o método de execução.

Os orelhinhas são transparentes, com a finalidade de aumentar o espaço visual, e coloridos, para ressaltar a finalidade do uso da peça.

O acrílico do orelhinha reflete parcialmente grande parte do ruído externo incidente sobre a calota e projeta o restante do ruído que entra pela abertura frontal para o seu foco, que se encontra deslocado do ouvido do usuário médio, oferecendo uma boa eficiência na faixa de 30 a 50 decibéis.

Os orelhinhas encontram-se instalados em muitos postes de telefônicos públicos, supermercados etc.

O projeto concha foi elaborado na mesma época que o orelhinha. As conchas foram projetadas especialmente para serem utilizadas em ambientes semiabertos, como é o caso dos postos de gasolina. Por ser externo, as restrições de espaço passam a ser pouco relevantes, o que nos possibilitou realizar uma forma mais adequada à nossa proposição de criar uma imagem mais completa da prestação de serviços do posto, por exemplo.

Foi então elaborado o modelo 1, o mais simples, cuja forma é resultante de dois cortes planos em uma esfera de $1 \mathrm{~m}$ de diâmetro, deixando uma abertura frontal ao usuário e adaptando-se à parede de forma integrar-se ao todo. Sua maior abertura frontal é acusticamente compensada pela maior distância do foco ao ouvido do usuário médio (1,75 m de altura).

Estes modelos estão instalados em grande número de postos Shell.

O modelo 2 lateral evoluiu do frontal, efetuando-se uma rotação 90o em torno do seu eixo, obtendose as seguintes vantagens, com um custo ligeiramente mais alto:

1. Maior eficiência acústica, pois fica diminuído o ângulo sólido de entrada do ruído;

2. Maior eficiência, privacidade e estética ao se formar uma série de laterais, em que um modelo é o "fechamento" do outro.

Este modelo não está ainda em uso e pode ser aplicado em locais semiabertos, onde haja grande concentração de usuários, como em estações rodoviárias, parques, estádios, pavilhões de feiras etc.

O modelo 3, lateral com aba, evoluiu do modelo lateral, complementando-o por uma aba cilíndrica, cuja superfície se adapta ao corpo semiesférico superior, concordando a espiral da aba com a abertura circular original, dando uma forma mais "espacial" à peça e também possibilitando maior 
proteção ao usuário contra chuva, vento etc, sendo que as características acústicas são as mesmas do modelo 2.

As conchas foram projetadas também em acrílico $(10 \mathrm{~mm})$, são transparentes e incolores, por se aplicarem em espaços semiabertos, onde o telefone é um elemento de apoio a uma outra atividade final. O princípio de funcionamento é o mesmo do orelhinha, sendo que as conchas são eficientes na faixa dos 50 à $80 \mathrm{db}$ de ruído.

Orelhão - O caso do orelhão é o mais delicado, pois deve atender a condições mais desfavoráveis: aplicação externa, a todo tipo de público. Alto nível de ruído nas vias públicas e atendimento a concentração diferente, para o que foi criado um modelo modular a três níveis, que pode ser facilmente desenvolvido para um número $\mathrm{n}$ de orelhões, bastando usar um adaptador adequado.

A sua forma foi desenvolvida com base no orelhinha, adequando-o à nova problemática e procurando atender a todos os itens da lista de registros propostos. Para o orelhão foi dispensada a transparência, necessária em ambientes fechados e semiabertos, o que possibilitou a alternativa de fiberglass, que aumentou ainda mais as condições de privacidade do usuário. Seu funcionamento é análogo aos anteriores, sendo que atende bem à faixa de 40 à 90 decibéis, acima do que uma cabine totalmente fechada será o ideal. 


\section{APÊNDICE 2 - CRÔNICA DE CARLOS DRUMMOND DE ANDRADE SOBRE O ORELHÃO, PARA O JORNAL DA TARDE DE 27 DE JANEIRO DE 1972}

\section{AMENIDADES DA RUA}

De repente - notaram? - a rua melhorou em São Paulo, com o aparecimento do telefone-capacete. Bem que eu queria falar sobre ele, mas bobeei, e Ziraldo, com aquele humour (sic) que não pede licença para explodir, disse em cartoon o que eu tentaria escrever sobre o Orelhão. Ah, Ziraldo, isso não se faz: ter, antes dos outros, as melhores ideias!

A verdade é que a rua ficou sendo outra coisa, com as pessoas descobrindo que não precisam mais fazer fila no boteco ou na farmácia para dar um recado telefônico. Na própria calçada, uma vez comprada a ficha no jornaleiro, comunicam-se. Tão simples. Em outras cidades desse mundinho que é o mundo, já se fazia isso há muito tempo, mas aqui é novidade grande/ gostosa.

A primeira experiência foi aquele fiasco. As cabinas cilíndricas despertaram a agressividade, o instinto predatório de alguns, e logo se tornaram ruínas. O usuário repelia a dádiva. Eram feias? Nem por isso. Eram úteis, mas os destruidores não repararam na utilidade. Vingavam-se, talvez, nas pobres cabinas, das frustrações e irritações acumuladas durante anos de mau serviço telefônico. Para não falar no gosto puro e simples de arrebentar, que dorme nas cavernas psíquicas do suposto civilizado, e que, se ninguém está perto para servir de alvo, ou com receio de levar a pior na arrebentação, desaba sobre as coisas, que não reagem.

A CTB não desanimou, e saiu-se com o telefone protegido por uma cuia invertida: um, dois, três aparelhos geminados. Agiu tão depressa, e bolou tão bem a coisa, que os vândalos ficaram tontos e não contra-atacaram, senão em escala mínima. A população tomou conta das cabinas, que não são cabinas, são uma cuia gozada, a céu aberto, uma cuia que fala. Simpatizou com elas. Aprovou-as.

Então começamos a reparar que a rua é afinal uma boa coisa, apesar dos automóveis que a entopem ou que fazem dela pista para treinamento para Fittipaldis em potencial. E, na rua, a calçada é aquela parte boa em que é bom ir e vir, parar e até telefonar. Com depósitos metálicos, onde você pode colocar o seu papel de sorvete. Com pontos de parada de coletivos, que indicam números de linhas à sua escolha. São pequenas viagens que se oferecem, em todas as direções. Sucedem-se as placas,prestando informações que todo mundo consome, sem ligar para o esforço que toda essa sinalização representa. Uma série de códigos em ação para sua segurança. O hidrante está ali, prevenido, para você poder continuar desprevenido. Ao lado dele, o telefone vermelho dos bombeiros. As pedrinhas que você pisa procuram diverti-lo, formando arabescos em preto e branco; de vez em quando interrompem o desenho para dar espaço a tampas que vedam condutos subterrâneos de que dependem a sua higiene, o seu conforto domiciliar, a sua vida. No leito da rua, pintaram listas amarelas que the permitem passar incólume, com ar superior de pedestre que despreza os motorizados, em frente à massa de carros subitamente imobilizados, impotentes para massacrá-lo. E não falei em 
outros serviços e dedicações mudas da rua para o citadino: a rua oferecida em árvores, toldos, lojas de tudo, escritórios, consultórios, jardins, cinemas, igrejas, oficinas; a rua, enciclopédia de utilidades e favores gerais. Tudo isso representando investimento, e que investimento colossal é a rua.

Nós a estimamos pouco, não sabemos prezá-la. Cuspir na rua, jogar-lhe detritos, conspurcá-la, são pecados que cometemos sem sentir, de tão habituados. Cobrar-lhe os defeitos, as lacunas, é costume velho. Mas celebrar-lhe e preservar-lhe as excelências, disso ninguém se lembra. Agora, o telefone-cuia dá ensejo para rimar, com satisfação".

Viva a cuia, aleluia!

E diz-se que vem aí uma nova caixa de correio, para aumentar as amenidades da rua. As que havia, raras e pesadonas, eram demasiado republicanas, com as armas nacionais em relevo dando a impressão de que só o Quintino Bocaiúva podia botar lá dentro sua correspondência; quem fosse monarquista, anarquista ou nada, estaria excluído. Desejo que a EBCT faça como a CBT: peça a um industrial designer que bole a caixa diferente, atraente, simpática: enfim, uma caixa que desperte no brasileiro, tão incorrespondente por natureza e por má educação, o desejo de escrever cartas, para o prazer de botá-las numa caixa bacana, a dois passos de casa; porque sendo a duzentos passos, o brasileiro desiste de escrever, mesmo que seja para pedir dinheiro ao pai. 


\section{APÊNDICE 3 - ENTREVISTAS REALIZADAS COM PERCIVAL LAFER}

Entrevista 1 - Transcrição de áudio

São Paulo/SP, 11 de setembro de 2016

G.G. Bom, a primeira parte então é falar um pouco sobre o começo da vinda da família, da instalação em São Paulo e por que que o comércio moveleiro foi escolhido como atividade?

P.L. Bom, a historia começa quando os meus pais vieram da Polônia e da Rússia para o Brasil, isso foi em 1923 e chegaram aqui como imigrantes, como tantos imigrantes judeus na época vinham com uma mão na frente e outra atrás, e eles se conheceram em São Paulo, foi aqui que se conheceram e casaram. A partir de 1924, o meu pai trabalhava como ambulante, como tantos outros imigrantes, então, ele saia, visitava os clientes pela cidade a fora e se instalou em São Paulo, e depois de um certo tempo, com uma evolução, ele já começou a ganhar algum dinheiro, então ele resolveu se estabelecer... agora, o por quê que ele começou um negócio de móveis pra mim... eu não tenho muito a informação do por quê, mas eu imagino... o meu pai era uma pessoa que gostava de fazer diferente dos outros, e o "grosso" dos imigrantes nessa época se instalaram no Bom Retiro e com um negócio de roupas. O meu pai pra ser diferente, em vez de ficar no Bom Retiro, ele se instalou no Cambuci, e em vez de trabalhar com roupas, com confecções, ele decidiu abrir um negócio de móveis. Bom, a minha interpretação para essa decisão dele é realmente pra se diferenciar do lugar comum, que aliás essa acho que é uma característica possivelmente que eu tenha... o mesmo tipo de inquietação, de fazer as coisas diferentes.

G.G. E o senhor viveu esse comércio de móveis na sua infância? Como é que foi viver essa atividade paterna?

P.L. Bem, então, ele começou... ele fundou a firma Casa de Móveis Lafer, ele fundou uma loja em 1927, foi quando a firma foi fundada, e se estabeleceu numa loja, a casa onde eles moravam era vizinha a essa loja, e foi prosperando. Eu quando nasci, dez anos depois, a firma já estava estabelecida. Eu, quando já me conheci como gente, fui tomar consciência das coisas já foi bem depois, uns 15 anos da fundação, já era um comércio estabelecido, já tinha uma tradição etc. Então, o meu contato com o negócio foi conhecer aquilo que meu pai fazia.

G.G. E que tipo de mobiliário ele comercializava?

P.L. Era um mobiliário residencial geral, ele vendia todo tipo de mobiliário pronto pra uma residência. Revendia, ele comprava de fabricantes e vendia na sua loja. Então tinha guarda-roupas, tinha camas, tinha o que na época era cristaleiras... todo tipo de mobiliários, sofás, cadeiras, poltronas e assim por diante. Então, era um comércio de móveis.

\section{G.G. E existia um estilo priorizado?}

P.L. Estilo... era o que tinha na época, né. Eu me lembro de estilos... os dormitórios de estilo provençal com aquelas volutas, os estofados eram também assim, uma espécie de decó mas uma coisa mais genérica, não tinha um estilo definido. Era mais ou menos eclético aquilo que ele vendia, é o que existia no mercado na época, o mercado que eu digo é o mercado de nível médio, essencialmente classe média. Ele não tinha uma loja pra classe alta, uma elite, até por que a localização da loja era num bairro de classe média. E, ao longo do tempo, ele foi se firmando como ponto, como marca, como referência, então ele criou uma tradição que foi o fundamento para a 
marca Lafer começar a se posicionar, embora muito discretamente mas tinha uma expressão no mercado.

\section{G.G. E ele nunca produziu móveis?}

P.L. Não, depois de muito anos, onde ele comprou um imóvel grande para fazer a loja maior, e era um terreno grande, e no fundo desta loja ele construiu um galpão com a intenção de fabricar dormitórios. Então aquilo que ele comprava de fabricantes em São Bernardo, que São Bernardo do Campo era um pólo industrial da época; todos os fabricantes de móveis, principalmente móveis de madeira se localizavam em São Bernardo, e ele pôs na cabeça que ele queria fabricar, mas essa aventura dele durou muito pouco. Ele fez uma primeira série e viu que a coisa era tão difícil, tão complicada que ele desistiu. Então, ficou lá o galpão e ficaram alguns equipamentos pra fabricação de móveis de madeira. Ou seja, então era o comércio, e quando eu já tinha idade pra assimilar esses conhecimentos, ele já tinha praticamente encerrado a curta carreira dele como industrial. $\mathrm{E}$ o que ele fazia não tinha nenhum desenho especial, ele pegou aquilo que já existia no mercado e simplesmente reproduzia.

G.G. Essa época convergiu com o início da sua formação como arquiteto e designer?

P.L. Bom, aí, quando eu estava com os meus 14, 15 anos... eu era o irmão mais novo da família... Meu irmão mais velho estava saindo da engenharia, estudou no Mackenzie, e meu segundo irmão fez arquitetura, então eu... por que que eu fui fazer arquitetura? uma mistura... acho que por um lado, o meu amor por criar coisas, segundo, pela influência da própria família, dos irmãos, e terceiro, essa minha curiosidade de criar formas e coisas desembocou no curso de arquitetura porque na época, por exemplo, não existia faculdade de desenho industrial, não tinha no Brasil. A primeira escola de desenho industrial foi a Esdi, no Rio de Janeiro, que começou, acho que ela surgiu na época que eu estava já na faculdade de arquitetura ou próximo disso, eu não sei exatamente a época. Mas essa minha... é uma coisa interna minha, essa coisa de inventar, de criar, de querer fazer coisas diferentes. Esses foram os inputs básicos que me levaram a fazer arquitetura.

G.G. Então, o senhor já criava antes dessa época?

P.L. Eu já brincava de criar, né. Já tinha umas coisas, umas brincadeiras que eu fazia já com a intenção ainda muito embrionária de fazer algo para vender, mas ainda num plano quase de brincadeira, de hobby.

\section{G.G. O senhor pode contar exemplos?}

P.L. Tem um exemplo... uma vez eu precisava de uma antena de televisão, aí eu peguei e estudei um pouquinho sobre o assunto, comprei um livro que ensinava o que eram as ondas FM etc, aí eu falei: Eu vou fabricar a minha própria antena para instalar em casa. Essa foi uma brincadeira, eu fiz uma antena, depois eu comecei a fazer para um e para outro, aí teve um primo que gostou da ideia e falou: Ah! vamos fazer isso aí e vamos vender, e foi um período em que eu subia nos telhados e instalava antenas de televisão. Esse é um exemplo...

G.G. Quantos anos você tinha?

P.L. Isso foi na minha adolescência. Acho que eu tinha uns 16 a 18 anos mais ou menos. 
G.G. Já na faculdade, quais eram as escolas que existiam naquela época?

P.L. Basicamente duas em São Paulo, que era o Mackenzie e a FAU. É isso, não tinha outras opções. E, a do Mackenzie era relativamente recente, no tempo do meu irmão mais velho, arquitetura era uma cadeira do curso de engenharia, mais tarde ela se desmembrou e foi criando a faculdade de arquitetura Mackenzie. Então, quando eu entrei ela já estava consolidada como arquitetura mesmo.

G.G. E daí o senhor foi para o Mackenzie...

P.L. Eu fui para o Mackenzie.

G.G. Por algum motivo especial?

P.L. Eu acho que por influência dos irmãos porque os dois estudaram no Mackenzie.

G.G. E esses anos escolares foram como? Acho que agora o senhor pode me contar um pouco sobre esse período de estudo na arquitetura...

P.L. Bom, acho que o grande aprendizado, mais do que as próprias aulas na arquitetura foi o ambiente que se vivia, o ambiente da turma, as discussões, apreciação daquilo que existia, os arquitetos mais conhecidos, tinha os alunos mais antigos da própria faculdade que já estavam se formando, por exemplo, colegas do meu irmão que já estavam exercendo a profissão, então, o ambiente da arquitetura, e essa visão da beleza da profissão do arquiteto... isso aí foi uma mistura do aprendizado de escola e do ambiente que eu tinha com colegas que eram muito participantes daquilo que acontecia, então a gente apreciava... tinha a interação com a própria FAU, nós tínhamos uma competição esportiva com a FAU, então existia de uma certa forma uma proximidade, proximidade também geográfica porque a FAU ficava a 100 metros de distância do Mackenzie. Então, o ambiente que eu vivi nesses anos da faculdade foram muito legais, muito bacana... os movimentos de greve, etc em prol da aproximação de uma arquitetura de mais vanguarda, que a escola no início era mais conservadora, o Mackenzie nos seus primeiros anos, ela era dirigida pelo Cristiano Stocler das Neves, ele é um ferrenho defensor da arquitetura clássica, então os alunos nos primeiros anos eles eram... fazia parte do currículo estudar arquitetura clássica, projetar coisas com temas clássicos, eu me lembro, por exemplo de lodgia, eu não sabia o que que era uma lodgia, então a gente projetou lodgia, como tem em Florença aquela lodgia, aquelas esculturas, né, então a gente era obrigado a fazer isso. Na cadeira de arquitetura analítica, a gente desenhava à bico de pena obras de arquitetura absolutamente clássica, renascentista, principalmente... então a gente tinha uma informação que acho que hoje não existe mais, né... não tem mais essa ligação. Isso foi bacana, foi importante. Quando eu fui a primeira vez à Itália, por exemplo, eu via essas obras todas que eu tinha desenhado em bico de pena, eu via elas na realidade, foi uma experiência muito legal. Então isso depois, com a pressão dos próprios alunos, combatendo essa tendência muito acadêmica de ir para uma arquitetura contemporânea, uma arquitetura de vanguarda...

G.G. Como que isso foi se introduzindo na faculdade, o senhor lembra?

P.L. O professor de Composição Arquitetônica, por exemplo, que era discípulo do Cristiano Stocler das Neves, ele foi posto pra fora da escola pelo movimento grevista na época em que eu estava lá, e aí foi substituído por professores com uma formação mais contemporânea, né, mais ligados aos movimentos... 
G.G. E sobre essa vanguarda, o que que chegava até os alunos naquela época? O que que era essa vanguarda?

P.L. Era a apreciação das obras... Niemeyer, acho que foi a maior influência da época, e tinha os outros, que acho que a maioria era do Rio de Janeiro, que era os irmãos Roberto, tinha o Sérgio Bernardes. Esses eram os arquitetos que estavam em evidência e que a gente apreciava muito. Mas, o Artigas não tanto, na época, porque o Artigas era muito ligado à FAU, e o engraçado é que havia na época um tipo de uma rivalidade entre FAU e FAM, então, se dizia que os arquitetos da FAU eram mais teóricos e os da FAM eram mais práticos, e os nomes e arquitetos que se adiantaram, que se projetaram no mercado eram muitos do Mackenzie embora com uma formação teórica menos avançada do que tinha na FAU. Era mais ou menos isso o que se falava na época.

G.G. Que ano que foi isso? O senhor concluiu o curso em que ano?

\section{P.L. Em 59.}

\section{G.G. No auge do Modernismo...}

P.L. Sim, Brasília estava em construção. A minha primeira viagem com os colegas de faculdade... nós fomos à Brasília na época da inauguração dela, da cidade. Então, esse era o momento histórico que a gente vivia na faculdade.

G.G. Com relação ao trabalho, como começou sua vida profissional? Foi concomitante com esses anos de estudo? Foi após? Obviamente, além dos trabalhos já desenvolvidos durante a adolescência e durante esse processo de formação, qual que foi a inauguração dentro do mercado profissional, e como que foi isso?

P.L. O negócio do meu pai... ele tinha dentro do comércio, como eu disse... ele tinha o equipamento de móveis de madeira, estavam parados, e ele chegou a ter uma pequena tapeçaria, ele chegou a comprar uma estrutura de madeira de fabricantes que já tinham produtos padrões pra fazer o estofamento, então, tinha um embriãozinho de uma oficina, e durante a faculdade eu passava algum tempo nesse ambiente. Ocorre que, inclusive ele tinha me pedido: Olha, eu tenho clientes que queriam fazer uma decoração com coisas especiais... então durante algum tempo eu fiz uns atendimentos de rudimento pra um ou outro cliente que queria uma coisa especial, então eu cheguei a desenhar alguns móveis mas numa escala muito embrionária. Mas o fato que marcou um ponto de inflexão na história foi que meu pai faleceu quando eu estava praticamente saindo da faculdade. Então, esse foi o ponto determinante e inicial na minha carreira como arquiteto, e com a morte dele, eu e os meus irmãos nos reunimos e decidimos em conjunto assumir a empresa dele e trabalhar nesse sentido, trabalhar juntos dentro da empresa. Não se falava em industrialização, absolutamente nada. Então, o que aconteceu a partir daí, recém saído da faculdade, eu estava lá dentro da loja e pelo meu temperamento, por tudo o que tinha como característica, eu falei: Bom, eu não vou ficar... que que eu vou fazer nessa loja? E então, eu peguei e comecei a desenhar, desenhar móveis... porque o meu interesse em criar coisas era indefinido, podia ser um projeto arquitetônico, podia ser um móvel, podia ser uma caneta, que aliás, eu fiz uma experiência durante a faculdade de fabricar uma caneta de desenho... que tinha uma caneta importada na época, de ponta de feltro, era novidade no Brasil, então, eu também comecei uma indústria para fazer caneta durante a faculdade. Então, eu comecei a desenhar tentando criar alguma coisa já com o objetivo de transformar aquilo num negócio grande, e foi assim que nasceu a primeira poltrona, a MP1, e que... primeiro, eu já fiz a concepção da poltrona não para vender na nossa loja, já fiz ela concebida para produção em série; isso é uma coisa marcante desde que eu nasci, fazer para fazer 
em larga escala. Então, a concepção dela foi feita com esta intenção, e começamos a vender essa poltrona usado os vendedores que vinham à nossa loja para oferecer produtos de terceiros: Olha, eu tenho isso aqui. Você não quer pegar isso pra vender? Então, eles pegaram toda a clientela que eles tinham, assim como meu pai era cliente deles, e em São Paulo... todos os lojistas de móveis. Eles pegaram a fotografia da poltrona e saíram vendendo, e era uma coisa absolutamente inédita como desenho porque não tinha nada a ver com o que se fazia na época, e para surpresa minha começaram a comprar. E eu disse: Bom, acho que aqui tem alguma coisa. Esse foi o start da indústria de móveis. Então, começou a ser feito nos fundos da loja, naquele galpão que tinha esse equipamento, e foi um período bastante curto já que ele saiu do zero já para uma escala, que já se podia falar que era uma indústria. Esse foi o primeiro período.

G.G. O nome já existia "MP Lafer", e a ideia por trás do nome já existia?

P.L. Não, o nome tinha a marca Lafer apenas, como comércio. A marca MP Lafer nasceu por que? Porque eu falei... bom, a minha proposta é fazer coisas diferentes, inéditas e portanto, eu vou me cercar de patentes para que elas não sejam copiadas, então eu criei a marca MP que significa Móveis Patenteados, e eu agreguei MP Lafer, criei um logotipo, que era uma etiqueta que passou a ser pendurada nos móveis e assim nasceu a marca MP Lafer. No início dizia... se falava em "móveis patenteados", depois eu eliminei isso e ficou só MP. Lafer MP.

\section{G.G. A MP1 então é essa primeira poltrona?}

P.L. O primeiro desenho é a poltrona MP1. O interessante é que a MP1, eu falei... bom, eu quero fazer só poltrona, não quero fazer nada mais do que isso... se alguém pedir sofá, a poltrona ela tem um meio de ligar um módulo ao outro, ela faz três poltronas pra fazer um sofá. No começo foi assim, mas o mercado não quis saber disso: Não, como? eu quero um sofá, não quero juntar três poltronas... aí já tive que fazer a contragosto, eu tive que fazer um sofá porque o que eu queria fazer em larga escala era só aquela poltrona. Então, esse foi o comecinho da história...

G.G. O senhor pode falar do processo criativo dessa poltrona? Então, de detalhes, de como ela foi concebida, quem tava com o senhor construindo isso? Os processos... passo a passo mesmo, desde o desenho ou da prototipagem... Como é que ela aconteceu?

P.L. O processo e criação ele varia, não é único... primeiro, o input para criar, ele vem de todas as frentes, ele vem daquilo que existe no mercado, vem de conversas com potenciais clientes, vem de conversas com os vendedores, e vem depois... nessa mistura de coisas, aquilo ficava na minha cabeça, e de repente eu tinha os estalos... Qual era a minha resposta para aquilo? E muitas vezes esse estalo acontecia durante o sonho, como eu acho que é bem frequente isso, né... aquilo fica no teu inconsciente e de repente... Então, eu via aquilo que existia no mercado do comércio em geral não me interessava em absoluto. Eu me interessava naquilo que existia de design no mundo afora, então observando o que existia... aí nasceu, não sei explicar exatamente em detalhe, mas essa foi a forma como a cabeça funcionou.

G.G. Como que ela é produzida, essa poltrona? Quais são os elementos-chave dela?

P.L. Ela tinha uma estrutura de sustentação metálica... e uma herança das aulas de concreto que a gente tinha na faculdade. Concreto armado o que que é? Uma mistura de concreto com aço. Eu falei, então, eu vou inventar uma "madeira armada". O que que é "madeira armada"? É uma mistura de ferro com madeira pra resultar num material novo. Então, ela nasceu desta forma, só 
que o conceito tá errado porque a madeira não reforçava nesse caso... ela simplesmente revestia o metal, né... então, o resultado o que que era? Uma peça de madeira mas que tinha resistência de aço, então era uma peça muito esbelta... isso, eu acho que foi uma parte importante nessa poltrona, que ela era muito delgada e muito resistente... Então, como é que uma peça de madeira pode aguentar o peso de... ? Esse foi uma das coisas... de uma ideia tirada do conceito do concreto aplicado de uma maneira totalmente diferente, com outro resultado... aliás, o concreto também é assim, né, você consegue fazer uma estrutura muito mais esbelta usando concreto armado, que com concreto maciço, antes da existência do aço, ficariam somente blocos de concreto, eles não tinham resistência à tração, só à compressão. Então, essa parte estrutural da base, agora a parte de cima é o contrário do que existia na época no uso de tapeceiros, essa é uma coisa importante... eu falei: eu não quero mão de obra especializada, eu quero uma mão de obra que você vai entregar pra fazer determinada operação, e ele vai fazer e pronto. Então, nunca contratei profissionais, então, para isso, o móvel tinha que ser concebido de uma maneira diferente... ele tinha uma estrutura de sustentação de madeira, tinha umas tiras de borracha pra sustentar o molejo, ao contrário das molas de aço que se usavam na época, tinha só espuma, ao contrário do que se usava na época, que usava crina, algodão... simplesmente isso: espuma, tiras de borracha e uma estrutura de sustentação em madeira, e uma capa de revestimento que era extremamente simples, ela só tinha uma costura, e o tecido era colado na espuma, então, tudo isso pra que? para criar um produto fácil de industrializar e que não dependesse de mão de obra especializada. Em resumo é isso, o resultado da poltrona MP1.

G.G. A MP1 chegou a ser produzida em larga escala?

P.L. Sim.

G.G. Ela foi produzida e vendida durante quanto tempo?

P.L. Boa pergunta... eu não tenho a data...

G.G. Aí o senhor já estava exercendo uma função de industrial, né?

P.L. Sim

G.G. Como que foi concatenar todas essas funções? de projetista, uma função financeira, de centralizador do conhecimento pra passar pra mão de obra, e essa gestão, né? Como é que era unir a função de projetista-design, essa função artística com a gestão de um negócio, que acho que dependia de outras variantes pra deslanchar?

P.L. Bom, uma das características da minha posição na empresa era que eu poderia fazer o meu trabalho de uma forma absolutamente livre e independente. Eu tinha os meus irmãos que cuidavam da parte administrativa, financeira, comercial, de modo geral... e ao contrário de um designer que faz um projeto para um cliente, esse cliente era eu mesmo, então eu tinha a missão de eu me satisfazer com aquele projeto, eu tinha que ficar convencido de que aquele projeto estava bom, então é uma característica importante para considerar porque eu não fazia para outros, eu tinha a liberdade de fazer o que viesse na cabeça. E a industrialização automaticamente em função do projeto, o processo de industrialização é consequência do projeto. Os materiais que você usa, a maneira que você concebe a produção... então, isso aqui eu exercia as duas coisas, eu tinha o pessoal que cuidava da fabricação mas eu é que dava as instruções do que precisaria ser feito, que máquina que precisaria ser adquirida... vou citar um exemplo, eu criei um sofá-cama, alguns anos 
depois, onde o tecido eu concebi que ele deveria ser colado na superfície toda do sofá, e lancei num tecido xadrez, então pra conseguir fazer com que esse xadrez ficasse perfeitamente alinhado, eu imaginei esticar o tecido primeiro num quadro com agulhas em toda volta, esse tecido era esticado por uma pessoa, e aí, o sofá era colocado em baixo, e ele era rebatido, então, ele passava a cola e simplesmente abaixava esse quadro em cima da espuma, então, o alinhamento do tecido no sofá era absolutamente perfeito. Então, esse é um exemplo da concepção à realização tinha o pensamento de como eu vou fazer isso que eu criei, esse é apenas um exemplo que eu lembrei ...

G.G. Isso faz parte do processo de modernização da produção?

\section{P.L. É...}

G.G. O senhor poderia contar um pouco mais sobre esse processo de modernização? Quer dizer, desde que o senhor pegou aquela fabriqueta que tava parada, como que isso foi se desenvolvendo através dos projetos? Daí se tiver mais exemplos...

P.L. No meu caso, eu não fazia móveis de madeiras, apenas poltronas e sofás, o projeto é que determina a industrialização, tudo é resultante do projeto, então, quando eu tô projetando eu tô pensando em como eu vou fazer isso em escala. Agora, a passagem da pequena escala para a grande escala o que determina são as vendas. A concepção do produto já inclui isso, já inclui a maneira que você pode reproduzir isso em quantidade, então na medida em que fomos aumentando o número de representantes começamos então a vender para o Brasil todo, então isso aí gerou o crescimento de vendas numa escala que já se poderia dizer que era uma escala industrial. Não é que houve um projeto para fazer uma fábrica para produzir x peças, isso foi uma coisa que foi crescendo gradativamente...

G.G. E essa pesquisa do maquinário e desse crescimento, e até como alteração do próprio projeto depois para adaptação pra esse novo maquinário, como é que se dava?

P.L. O maquinário era comprado em função das necessidades que o projeto determinava. Eu tinha o contato com o fabricante de máquinas constante... quer dizer a minha interação ia muito além do projeto... eu tinha muitas reuniões com a equipe de venda, por exemplo, e nessas reuniões, quando eles me traziam informações do mercado, vou dar um exemplo... Fulano de tal disse que gostaria de comprar a peça em vermelho... então, esse tipo de informação era a minha fonte de referência para armazenar na cabeça e depois sair com as minhas respostas. Então esse era o diálogo, mas o ponto de partida, o ponto essencial era a determinação de querer fazer um produto em larga escala e distribuir em larga escala, ou seja, levar design pro grande público, esse é o ponto chave, eu diria... o ponto de partida que me norteia até hoje, né...

G.G. O senhor já usava a palavra design na época?

P.L. Sim.

G.G. O que o senhor compreendia e como é que se deu a evolução disso? O que o senhor compreendia como design? Obviamente isso foi sendo transformado ao longo do tempo da atuação, né, mas nesse início, o senhor teve um vislumbre de como isso era encarado, inclusive pela população que comprava isso?

P.L. Bom, o design... tudo isso que eu falei, isso aí é expressão do design, é a concepção de um 
produto para distribuição, aliás, eu não entendo design como uma peça que é feita pra reproduzir um número limitado de peças, isso pra mim não é design. Design pra mim é reprodução em escala pra colocar um produto de boa qualidade, de boa forma, de boas características de durabilidade, de conforto e tudo mais, a um preço que o grande mercado pode comprar. Pra mim design é isso, e sempre foi. Acho que é isso, resumindo.

G.G. Então é quase uma... o senhor faz uma relação com os seus colegas que estavam produzindo design nessa época, nessa chave de concepção do que é design? Ou dos ensinamentos do Modernismo, da Bauhaus etc?

P.L. Daquilo que eu conhecia, o que eu assistia eram pessoas com desenho de alto nível, de bom nível mas eles não tinham essa preocupação de alcance de mercado... eu diria desenhos mais puristas, pessoal que se preocupava em ter um produto perfeito mas não a preocupação de vender o produto pra deus e o mundo, e essa é a diferença básica, então, por conta disso, eu fiz concessões muitas vezes... Ah, mas o mercado só pode pagar $x$ preço... Bom, então eu vou fazer isso assim assim... A moda não é por aí, é outra coisa... Muitas vezes a minha resposta eram desenhos que eram discutíveis em termo de qualidade e de desenho... isso faz parte também da história...

G.G. Como era viver isso frente ao produto perfeito que as pessoas estavam buscando?

P.L. Às vezes eu virava a cara pro meu próprio desenho mas... bom, mas é isso que o pessoal quer então é isso que eu vou fazer...

G.G. A partir desse primeiro desenho, como que os outros desenhos foram sendo desenvolvidos e produzidos? E qual é o momento que o senhor considera a fundação da MP Lafer? É o MP1 já?

P.L. Foi a MP1 mas, em seguida veio... não é tão em seguida, depois de uns 4 anos que já tinha a MP1... e era basicamente só a MP1... mas tinha um derivado dele que era MP3 e MP5; eu comecei a me preocupar em criar um sofá-cama, e esse sofá-cama tinha que ser algo revolucionário, aquilo que existia no mercado na época, e o mercado de sofá-cama era muito grande no Brasil, o que tinha na época eram sofás pesados, volumosos e que tinha um mecanismo que era único que existia no mercado, que fazia click-clak, levantava assim... fazia click e abaixava... Eu falei: Bom, eu vou criar um sofá-cama com o meu conceito de industrialização e preciso pra isso criar um novo mecanismo, então a criação de mecanismos é uma parte importante no meu trabalho, é uma coisa que me fascina e foi a primeira oportunidade que eu tive de me debruçar sobre um projeto com esse nível de detalhamento necessário, que é um projeto que eu diria de engenharia industrial, que era quase... eu fiquei mais de uma ano pra fazer esse projeto, e ele resultou num sofá esbelto, assim como era a MP1, que ele abria e fechava de uma maneira inédita, que era pisando num pedal pra ele abrir e pisando novamente pra ele fechar, não precisava por a mão no sofá pra ele abrir e fechar. Essa foi uma revolução no mercado, maior que a MP1, e pelo alcance que tinha o mercado de sofás-cama permitiu que a gente partisse para a divulgação publicitária a nível nacional, então eu procurei uma agência de publicidade e fizemos uma campanha pra vender esse novo sofá-cama. Esse foi então um momento, um salto de ir já para uma industrialização e pra uma dimensão de fábrica muito maior.

G.G. O sofá é MP...?

P.L. MP7. 


\section{G.G. Como é que o senhor organiza essa nomenclatura?}

P.L. Uma coisa... tem uma curiosidade aí... a minha ideia era MP1, MP2, MP3... aí, o MP2 eu não me lembro o que que era, acho que alguma coisa que não deu certo... em seguida vem a MP3, onde meu irmão arquiteto, ele cuidava da área comercial, mas aconteceu que eu casei nessa época e quando eu sai de viagem de lua de mel, ele desenhou uma poltrona, e essa poltrona é MP3, e ela está no catálogo e todo mundo acha que é minha, mas não é, quer dizer, parte é minha, a estrutura de sustentação é minha mas o desenho do corpo do móvel foi ele que fez, é muito bonito, todo facetado... aí quando eu voltei eu fiquei muito bravo, fiquei muito enciumado, então em cima disso, eu fiz uma outra variante que misturou o corpo da MP1, que era aquela minha sempre ideia fixa de maximizar o componente... eu peguei o corpo da MP1 e usei na estrutura da MP3 e resultou na MP5... aliás, ele disse que está muito bravo, diz que vai me processar porque o pessoal quando vê aquela poltrona pensa que é minha e eu falei, bom... pra explicar isso é meio complicado... e ele disse que vai me processar por causa disso (risos). Mas então... então a nomenclatura ficou tudo em número ímpar, 1, 3, 5, 7, 9 e assim por diante... nunca fiz nada com número par. Simples assim, nenhuma outra razão especial.

G.G. E existe uma divisão? 1 é uma coisa, 3 é outra coisa... o final indica alguma coisa?

P.L. Com o tempo foi se solidificando que o algarismo terminal indicava de uma certa maneira qual o tipo de produto que era então o número 1 ficou para poltronas e sofás como grupo do conjunto, o 3 pra poltronas individuais, o 5 pra módulos... mas isso não é rígido, é só indicação... o 7 pra sofácama, por isso que o MP7 iniciou como sofá-cama, o 9 pra poltrona ou sofás também, mas o 1 era pra sofá de preço maior, de nível mais alto e o 9 era médio, e foi isso, é só... não é nada rígido em termos de catalogação, nada disso, mas é o que a gente passou a usar. Por isso "salteava"... às vezes, eu passava de 11 pra 15 porque não tinha nenhuma poltrona no meio pra lançar então o 3 pulou... nada importante.

G.G. Quanto ao processo de pensamento de projeto, eu gostaria que o senhor falasse um pouco sobre como se dá esse pensamento de projeto dentro da sua obra... então, qual é o lugar do desenho, qual é o lugar do protótipo, como é que se dá? Existe uma dinâmica, cada produto impõe sua dinâmica? Como é que se dá isso? Como é que funciona esse processo de projetar?

P.L. Ele sempre foi espontâneo, resultante de ideias que eu alimentava, que eu ia registrando na minha cabeça, e as fontes, como eu disse antes, as mais variadas, desde o que tem no mercado similar, ou o que os clientes falam, o que os vendedores falam, ou o que a minha cabeça fala, então, a mistura de tudo isso, não é uma coisa metódica, é uma coisa espontânea, e assim foi. O primeiro foi resultado de uma gestação dentro de mim, mas os outros já começaram a ter os inputs externos, das condições do mercado... o mercado tá exigindo um produto mais econômico ou não, a entrada na exportação... tudo isso eram informações que eram alimento para pensar qual seria a minha resposta pra ... e aí nascia o projeto.

G.G. E o projeto, ele se dava como? Era desenho, era protótipo?

P.L. Era esboço e protótipo. Eu só desenhava aquilo que tinha mecanismos, então se tinha uma construção geométrica então eu usava aquilo que eu sabia de desenho geométrico... os mecanismos articulados, o primeiro deles foi a MP7 já, e depois todos os outros que vieram em seguida que eram ... uma coisa marcante naquilo que eu fiz, eram coisas que realmente brotavam... eu quero fazer um negócio que faz isso, isso e isso, diferente ... o diferente era sempre 
na minha cabeça, fazer algo diferente, novo, que não existe... então eu desenhava o esboço da forma, em seguida passava diretamente pra produção com os meus assistentes, que tinha de madeira, de tapeçaria e serralheria, então com esses três grupos de pessoas que eu executava os protótipos...

G.G. E entre a primeira peça produzida e a peça final tinha alguma variação?

P.L. Tinha, era quase uma escultura, eu fazia, depois ... não tá bom assim, mudava isso, aquilo. É um processo artesanal aí... nessa fase, ele é muito artesanal, até hoje. E depois que tava terminado, aí sim partia pra industrialização.

G.G. Até hoje essa lógica de projetar...

P.L. É, como eu não tenho conhecimento hoje pra projetar em computador, em CAD, em 3D, que eu gostaria muito, aliás, de aprender, mas nem sei se é viável fazer um projeto com esses recursos que existem hoje em dia... mas continua sendo assim até hoje.

G.G. Qual é a vantagem da prototipagem na sua concepção? O que que o senhor vê de vantagem dentro de um processo de prototipagem que não está vinculado diretamente a uma ferramenta de projeto, uma prancheta, um papel, desenho... mesmo fazendo referência a essa instância da escultura que o senhor faz?

P.L. Eu não chamaria de vantagem, eu chamo de característica minha, é a maneira que eu comecei... é demorado muitas vezes, mas tem exemplos dos dois lados... tem projetos que foram muito rápidos e outros que ficaram mais de um ano até a conclusão, até chegar naquilo que eu queria, então aí não tinha prazo fixo, era uma coisa que dependia da evolução do próprio sucesso do projeto, e outros que ficavam abandonados no meio do caminho porque não iam pra frente. 
Entrevista 2 - Transcrição de áudio

São Paulo/SP, 07 de setembro de 2016

G.G. O final 1 era uma série?

P.L. O final 1 era conjuntos, o final 3 era poltronas individuais, o final 5 eram modulares, final 7 sofas-cama, 9 era nada específico... e eram sempre números ímpares, não tem 2, 4, 6, 8...

G.G. É por isso que tem essas comunicações entre esses desenhos...

P.L. Entre o 141 que está aí e o 111, no tempo, ele não é tão distante, entendeu? Então 41, 61, 71, 81 , todos eles 91,101 , todos eles ... desse tipo de família que tinha o conceito tanto visual como produtivo, processo produtivo...

G.G. É... porque fica claro, quando vc pega 41 e $51 \ldots$

P.L. Eles são diferentes mas...

G.G. Eles têm o mesmo peso, né... e a mesma proposta

P.L. Pulava às vezes... entre o 41 e o 51 talvez não tivesse ainda os intermediários porque era de outro tipo de produto. por isso parece que as vezes eles estão aparentemente distanciados no tempo mas na verdade não estão, eles estão próximos... só a numeração não explica a cronologia...

G.G. O 1 então eram conjuntos, e são peças-chave, pelo que eu entendi...

P.L. São conjuntos, sofá e poltrona formando um conjunto.

G.G. E mesa?

P.L. A mesa correspondente àquele modelo.

G.G. Daí o 3?

P.L. O 3 eram poltronas sozinhas, todas as poltronas tem final $3 \ldots$

G.G. Daí tinha o final $5 \ldots$

P.L. Mas, inclusive esse tipo de catalogação não é desde o início que aconteceu, então os primeiros modelos não tinha isso, era sequência mesmo... Acho que depois do... acho que foi o 41 que foi o primeiro que...Todos existiram, mesmo que eles não nasceram necessariamente, entre o 41 e 0 $51 . .$. pode ser que ...

G.G. Isso já explica muita coisa dessa catalogação, que para mim... eu não vejo muito... eu acho ótimo pra você fazer um catálogo, mas pra esse trabalho agora eu não vou usar... agora eu vou ter que arrumar aquele sumário que eu mandei pra vocês e começar a destrinchar... contextualizando tudo... e daí sim, traçando uma linha de análise inclusive com ... a minha intenção é criar uma 
análise pelos modelos, pelo campo de atuação, pela época de atuação, que era uma época complicadíssima pra todo mundo, e onde o mobiliário de casa não estava sendo desenvolvido plenamente, pois a ditadura incentivou só o mobiliário de escritório... as grandes indústrias que cresceram durante a ditadura forma os mobiliários de escritório, né... o mobiliário de casa ficou reduzido a uma produção insípida...

P.L. Verdade... no casa da ditadura, o governo militar que foi 64 foi o que deu start à exportação nossa... quando eles queriam estimular a exportação de produto manufaturado... tinha uma reunião na FIESP, e nessa reunião, que eles ofereceram espaço na feira... você sabe dessa história, né?

\section{G.G Não...}

P.L. Em abril de $65 . .$. então, essa reunião deu start pra eu ir pra fora. Em 65 foi a primeira exposição dos produtos que eu tinha na época... era um feira na Suécia, eu falei... Bom, Escandinávia... eu vou lá pra aprender, né... é o berço do design... levei m MP7, o MP9... aquilo que eu tinha naquele momento, e aí começou começou a correr em paralelo o desenvolvimento de produtos específicos pra exportação. O MP41, por exemplo, o que tem no Brasil é nada, 95\% foi exportado, aqui vendia quase nada. Então, esses exemplares que tem, que você tem etc. comparado ao que foi pros EUA é zero...

G.G. E tantos outros, né...

P.L. Todos esses que seguiram essa concepção de forma e que a gente industrializou ao ponto de ter um preço acessível ao mercado e isso explica o porque que a gente vendeu tanto naquela época...

G.G. E tem a coisa do mobiliário familiar, né... que estancou numa escala que acho que nenhum dos designer da época atingiu...

Filha: Mas você sentiu essa canalização pra móveis de escritório na época...?

P.L. Sim... escritório sim... aqui tinha firmas que se desenvolveram...mas é que a gente seguia o nosso caminho, por isso... a gente construiu o nosso próprio caminho. Como você disse, surgiu vários móveis de escritório já ligados a design, escriba, mobilinha... né?

G.G. Muitos, né... o que desenvolveu nessa época foi isso... daí só vai voltar o mobiliário de residência ... daí tem essas produções episódicas dos designers brasileiros que a gente chama de móvel de autor, né... inclusive acho que isso ... daí o senhor possa até falar mais, mas eles produziam pouco e tinha essa reverberação toda frente a um mobiliário que era tão... construído tanto mas que por estar nessa escala maior ficou... atendeu à margem...

P.L. À margem daquela caracterização restritiva do móvel de autor, né... essa é a grande diferenciação entre o trabalho que eu fiz e entre o trabalho que existia nessa concepção de design de autores, ... era uma coisa que eu chamo de mais elitizada, né... quando eu... desde o começo a ideia era encher o mundo com isso, o ponto de partida, de princípio...

G.G. Agora, o ponto de partida que a gente pode botar nesse ranking de móveis de autor que agora, entendendo melhor, fazem parte dessa linha número 1, não todos, acho que tem outros, mas os que vem à cabeça são esses de final $1 . .$. tem uma relação com a exportação? 
P.L. Nao, relação com a exportação foi a partir de 65, a história começou em 61 com a MP1, e nesses primeiros quatro anos era focado no mercado brasileiro, depois em 65 foi o start da exportação mas sem perder aquilo que eu fazia no mercado local, muito pelo contrário, foi esse o grande período de crescimento nosso foi no mercado local... a exportação tinha uma porcentagem da venda, do faturamento, mas não era majoritária, era minoritária... ao contrário de hoje, curiosamente, hoje a exportação é mais de $50 \%$ do nosso negócio. Engraçado isso... por que mudou tudo, mudou a nossa distribuição, nós encolhemos, nós saímos do mercado aqui e tal... essa é a principal razão... por razões internas, razões de estratégia da empresa.

G.G. E, desde 61 até esse encolhimento do mercado nacional, o nicho de mercado era a classe média?

P.L. É... média, média-alta, né...

G.G. Média, média-alta... que é quem tinha acesso inclusive cultural pra poder absorver esse tipo de desenho...

P.L. Exato, mas aí que entra a surpresa que foi uma expansão além do que a gente esperava... quem comprou o nosso design... eu tinha contato com as pessoas, não eram pessoas que tinham conhecimento de design, pra entender o diferencial... era quem simplesmente gostava...Gostavam e ponto final... pelas qualidades... pela praticidade, não necessariamente pelo preço porque pelo preço que a gente vendia tinha alternativas convencionais, que tinha no mercado. Nosso preço não era melhor do que um concorrente qualquer, mas, seja qual foi a razão... foi uma surpresa pra mim que essa linguagem pegou e se espalhou... e aí, nessa primeira fase a gente não fazia divulgação publicitária, não existia isso, só veio existir a primeira publicidade nossa em 65 , nada a ver com esse capítulo da exportação mas porque eu lancei um produto que tinha características bem revolucionárias, onde o produto precisava ser divulgado...

G.G. Que era a mini sala?

P.L. O sofá-cama MP7. Ele era tão diferente, tão revolucionário que eu falei ... Tá na hora de a gente fazer uma campanha de publicidade pra incrementar, e foi isso que aconteceu..

G.G. E essa aceitação, o senhor acha que tem a ver com essa publicidade...?

P.L. Não, porque já vinha de antes, dos nossos primeiros modelos...

G.G. E o senhor pensa no que que foi... que chaves foram atingidas dessa população brasileira que estava entrando em contato com esse móvel moderno na época? Quais são as chaves, a forma, 0 conforto, a durabilidade...?

P.L. Uma característica que eu acho que o público que comprava o nossos móveis, era de uma faixa etária mais baixa, eram mais os jovens, os jovens casais que davam preferência ao nosso produto... 
Entrevista 3 - Transcrição de áudio

São Paulo/SP, 18 de setembro de 2016.

\section{G.G. Como começa a experiência com a fibra de vidro?}

P.L. Inicialmente para a Kibon, que queria um quiosque e eu projetei, acho que esse foi o primeiro projeto nesse campo. Depois vieram as cabines telefônicas, nós desenvolvemos o orelhão na época, onde o projeto veio da companhia telefônica, de uma arquiteta que trabalhava na companhia telefônica, ela tinha o desenho básico, o conceito do orelhão... nós desenvolvemos a forma do orelhão e passamos a produzi-lo em grande escala, então nessa época eu projetei outros itens para as companhias telefônicas, eram... cabine telefônica, cabine fechada, e cabines modulares pros postos telefônicos que existiam na época. A pessoa pra fazer interurbano, ela ia num posto telefônico e tinha aquelas cabines numeradas, então eu fiz um projeto muito interessante que eram modulares, que conforme o tamanho da agência podia colocar várias unidades. Chegamos a fazer um trabalho interessante nisso aí.

G.G. Eles eram todos produzidos em fibra de vidro?

P.L. Sim.

G.G. Com relação a comunicação desses projetos, então, Kibon, as companhias telefônicas, certamente existia uma especificidade do projeto que era a comunicação da marca, a programação visual... tudo isso era pensado dentro da indústria pelo senhor, ou isso vinha pronto? Existia uma possibilidade de projeto total ou era uma coisa segmentar?

P.L. Não, era segmentar, e vinha de várias fontes. Tem produtos que nós desenvolvemos, por exemplo, um spoiler aerodinâmico pra uso nas cabines dos caminhões... então em termos de mercado, houve então uma diversificação de mercado, isso já era um componente da indústria automobilística... produzimos para as próprias indústrias, pra FIAT nós fazíamos também um tipo de spoiler que vinha em cima da cabine, que era já pensando em aerodinâmica pra economia de combustível. Esse período já estava... a ideia da criação do automóvel já estava em pauta.

G.G. Essa ideia da criação do automóvel estava de acordo com o crescimento da indústria do automóvel, né, isso é claro. Ou não? Ainda era pioneiro?

P.L. Ela ocorreu paralelamente sim porque a indústria automobilística tinha tido um impulso no governo do Juscelino no fim dos anos $50 \ldots$ aliás foi Juscelino que iniciou o processo de industrialização do Brasil com um todo, né, e a indústria automobilística quando começou a se instalar aqui ela abriu um campo enorme de desenvolvimento tecnológico, produtores que produziam componentes pra própria indústria... a industrialização brasileira acho teve um salto considerável nesse período, né...

G.G. Falando da indústria agora, já que a gente entrou nesse tema... como é que o senhor dividiria as fases de crescimento da Lafer... se der pra pautar por anos, seria ideal... quais foram os saltos, né, então, de tanto a tanto um salto relacionado a isso...

P.L. Os primeiros anos foram esses dos primeiros projetos, MP1... de 1 a 5 . O primeiro salto foi com a criação do sofá-cama, o MP7... Esse foi o momento já de transição de uma produção relativamente ainda pequena para um salto, mas por que que aconteceu isso? Por que este projeto 
era muito revolucionário, tinha um conceito completamente diferente de qualquer coisa que existia desde então, nem aqui nem fora do Brasil, então, ele representava realmente uma inovação, a ponto de termos então partido para uma divulgação publicitária, isso trouxe obviamente um salto na venda e na consequente produção. Além disso, ele representou o primeiro projeto de concepção de estruturas articuladas meus, que passou a ser uma constante na minha vida, então, de criar móveis articulados pra exercer múltiplas funções. O passo seguinte foi o salto em direção à exportação, ainda no mesmo ano de lançamento do MP7 fizemos a primeira iniciativa no sentido de entrar no mercado externo, isso foi na Suécia em 65, esse é o segundo salto que representou uma mudança significativa na própria criação de projetos como na exploração de um mercado novo, então começamos a pensar em que produtos teríamos a possibilidade de criar para vender e competir no mercado externo, em mercados desenvolvidos, citando por exemplo... o Brasil na época, o que tinha de exportação de produtos brasileiros eram produtos em geral de madeiras do sul do Brasil que eles faziam de acordo com as especificações dos importadores, ou seja, eles compravam produtos que podiam comprar em outros mercados, eles vinham buscar mais barato no Brasil, então era uma produção sobre desenho vindo de fora, então, nesse sentido, eu acho que eu fui realmente o primeiro ou um dos primeiros que começou a criar desenhos pra desenvolver produtos com o nosso desenho, e isso aconteceu inicialmente num ritmo lento e depois alguns anos mais tarde, nós fomos da Suécia pra Alemanha, onde fizemos uma filial, e começamos a distribuir na Alemanha da mesma forma como distribuíamos no Brasil, vendendo pra lojistas do país inteiro, arrumamos uma equipe de venda que visitava as lojas na Alemanha e vendia nosso produto. Isso foi no final dos anos... início já de 80 , final de 70 , início de 80 . Isso foi então o salto em direção à exportação. 0 salto posterior acho que veio em dois momentos, 1 com a produção dos orelhões, mas daí já era um produto que não era a criação nossa e sim de terceiros, mas que se transformou em um produto importante para empresa, e em seguida, a criação do projeto MP Lafer, do automóvel.

\section{G.G. A criação do MP Lafer marca o ápice da produção da indústria?}

P.L. Não por causa do produto, mas pela época em que se produzia. Acho que atingiu o ápice em termos de produção porque o país estava naquele momento, um momento de expansão forte, então era um conjunto de coisas por que a gente tinha não só o automóvel... porque o automóvel em termos de venda mesmo, em volume de venda, ele não era tão importante quanto a imagem que ele projetou, mas o grande volume vinha no Brasil da venda dos móveis, e também das exportações que estavam crescentes.

G.G. Dentre todos esses passos de produção e crescimento industrial qual foi o passo o qual foi o ano que o senhor elege e que marca essa consciência do industrial, de produção industrial?

P.L. Olha, eu acho que desde o primeiro projeto porque essa era a premissa, esse era o meu objetivo. O resto foi acontecendo...

G.G. Ok. A gente já falou um pouco das inovações tecnológicas... dentro desta premissa de criar uma indústria e de produzir para uma indústria, qual que era o papel da inovação tecnológica no crescimento da mesma?

P.L. Aí eu volto a dizer que o componente principal é o projeto, a tecnologia, ela vinha para auxiliar a execução daquilo que era projetado, então é uma coisa que não dá para dissociar uma da outra, a tecnologia vinha em consequência do projeto.

G.G. Dentro do contexto pouco tecnológico da época, como é que era ser condutor, gestor de uma indústria que investia em tecnologia? 
P.L. Era o uso da criatividade para buscar coisas que não eram facilmente disponíveis no mercado, ou seja, a construção dentro da própria indústria de meios de produção para realizar aquilo que era criado, então a tecnologia que existia na época, era feito a busca daquilo que existia e a datação daquilo que existia pra fazer aquilo que a gente queria fazer

G.G. Quais foram as principais tecnologias introduzidas pela Lafer dentro da produção do mobiliário e de outros projetos?

P.L. Eu acho que foi a introdução da espuma injetada, e a tecnologia aplicada no uso da fibra de vidro para a produção das peças injetadas. Esse foi o elemento-chave para passar de uma fase de industrialização relativa para uma industrialização avançada

G.G. O beneficiamento das madeiras, quer dizer, o trabalho sobre a madeira e sobre o metal, ele ainda seguia sob o modelo antigo ou ele sofreu uma modernização?

P.L. Passamos a utilizar equipamento de ponta para realizar aquilo que era criado, e aí nós tivemos que recorrer a importação de equipamentos, pra produção em larga escala de perfis madeira, usinagem, acabamento com esteiras de produção em série para pintura...

G.G. Dentro dessa lógica, o senhor poderia falar sobre a setorização das coisas da sua indústria? Então, quais eram os diversos setores pelo qual o produto passava, desde os setores de produção até os setores administrativos, marketing... como é que foi a construção de toda essa estrutura?

P.L. No aspecto Industrial, a estrutura eram várias fábricas dentro de uma fábrica. Então, tinha uma área da fábrica que era só para componentes de madeira, tinha uma área que era para fabricação de componentes metálicos, uma outra para fabricação de componentes de fibra de vidro, uma outra para a produção de espumas injetadas, uma outra para a produção de espumas manufaturadas, um outro departamento que era montagem, a junção de todos esses componentes na produção de móveis, então, era como se fossem várias fábricas dentro de um único espaço, e essa diversificação, essa verticalização é que me permitiu de entrar em tanta diversificação de produtos e de mercados. A parte administrativa seguia paralelamente como à serviço da produção, da mesma forma o departamento de vendas, de marketing... mas, o ponto central que coordenava tudo isso era o produto, o produto era o que definia o que precisava ser feito na área de venda, na área de produção e assim por diante. Quer dizer então, volta e meia eu volto a me referir ao projeto como sendo o ponto de partida para todos os periféricos.

G.G. O senhor recorria a outras bases industriais para acabamento, pra distribuição ou tudo estava realmente concentrado nesse campo industrial?

P.L. Eu acho que sempre houve fornecimento de terceiros em determinadas coisas, mas eram minoritários. O importante, a parte principal do produto era feita em casa mesmo.

G.G. Dentro de um dos passos do crescimento da indústria, talvez um dos principais tá a exportação. Como é que se deu, qual que é a história dessa exportação?

P.L. O ponto de partida foi uma viagem de curiosidade, uma oportunidade de expor alguns produtos numa feira na Suécia em 65, foi o primeiro contato que eu tive com o universo fora do Brasil. A partir desse momento, pelo resultado da apresentação a gente teve um início de vendas naquilo que a gente já fazia, mas imediatamente após já tendo um feedback do mercado dizendo o que que eles gostariam de ter, quando então eu comecei a projetar produtos pensados diretamente para a 
exploração do mercado externo, e era basicamente aquilo que o Brasil tinha como imagem, um país tropical, exótico, então, o que que eles esperaram assim... produtos de materiais naturais, obviamente, couro, madeira... e foi aí que nesse processo eu fui conhecer... aquilo que o Brasil já tinha mostrado teve um papel importante, a poltrona Mole que tinha já recebido um prêmio na Itália era uma referência para aqueles que já tinham uma noção do que o Brasil tinha para oferecer como potencial.

G.G. Partindo da Suécia quais outros países...?

P.L. Alemanha em sequência, depois, Estados Unidos. Quer dizer são dois grandes mercados, né, na Alemanha a coisa aconteceu através de um conhecido nosso que tinha um comércio de produtos que ele vendia para brasileiros, então ele tinha já o conhecimento do Brasil, dos clientes, etc, e éramos amigos e ele colocou como objetivo dele, pessoal, de vender produtos brasileiros, ele tinha um sonho, ele queria ganhar a ordem do Cruzeiro do Sul do governo brasileiro para vender produtos brasileiros lá, e ele foi atrás com todo empenho, então foi um período que o crescimento foi muito grande nos Estados Unidos. Ele abriu uma série de lojas, criou uma marca, Brasil Contempo e foi um case no mercado americano, foi o primeiro negócio de venda exclusivamente de móveis de couro.

G.G. Isso dura quanto tempo?

P.L. Isso começou nos anos 70 e foi até início de 90.

G.G. Era comum naquela época se fazer adaptações ao desenho para exportação, isso acontecia também na produção da Lafer?

P.L. Não, era o contrário, o produto era criado para exportação, e depois eu fazia simplificações no produto para tornar ele viável para o mercado nacional, foi exatamente o contrário...

G.G. Que Impacto isso tinha dentro desse contexto de época?

P.L. Bom, nós tínhamos produtos que eram muito bem-sucedidos nos dois mercados tanto fora quanto aqui, nas suas respectivas versões, outros, eles eram mais sofisticados então quase não se vendia no Brasil, vendia-se quase que só na exportação... A universalização de desenho, que atendia globalmente, veio com as poltronas reclináveis...

G.G. Universalização de desenho, o que que significa isso?

P.L. O mesmo desenho, o mesmo produto vendido tanto no Brasil como fora. Acho que isso aconteceu por dois motivos: um, pelas características do produto, e depois pela própria globalização, o movimento global que hoje tá vigente, as pessoas... em qualquer lugar do mundo você vê os mesmos produtos serem vendidos, né...

G.G. Esse movimento contrário de desenho... diretamente para exportação, como ele favorecia o processo industrial, tem uma ligação direta?

P.L. Sim, mais uma vez pela concepção, primeiro os móveis eram totalmente desmontáveis, o que facilitava a fabricação e a logística toda de distribuição. A desmontabilidade do produto tinha dois motivos pra existir: primeiro pela própria concepção de racionalização de produção, e segundo, 
tem um ponto que foi muito importante na exportação é que tornava os móveis compactos porque na época o freter era absurdamente caro do Brasil pros Estados Unidos, então ele incidia sobre o preço do produto de uma forma brutal, então eu consegui contornar esse problema fazendo os produtos compactos, eles eram achatados dentro de uma caixa, um sofá era embalado dentro de uma caixa de $27 \mathrm{~cm}$.

\section{G.G. Foram exportados apenas móveis?}

P.L. Não, automóveis... Tivemos um período em que tínhamos um cliente na França, que esse sim, ele trouxe o desenho do que ele queria e nós usamos a nossa capacidade produtiva do setor de madeira para fabricar, eram portas de armário de cozinha, foi um período em que fizemos em grande quantidade isso. Ou seja de modo geral eu estava sempre aberto para oportunidades... se o desenho vinha de fora ou seja o que fosse, era uma coisa que... a vontade de fazer as coisas era permanente, constante...

G.G. Isso tem ligação com uma cultura familiar?

P.L. Acho que não, é uma coisa bastante individual mesmo...

G.G. Eu gostaria que o senhor falasse sobre alguns móveis... para começar, a linha 1, de finalização 1, então fala desde o projeto, como foi produzido, quais foram os desafios técnicos, logísticos, econômicos da produção desses móveis... as inovações, o recebimento... falar quase contando uma historinha mesmo de cada um dos móveis. O primeiro, o MP 1, a gente já falou... 0 segundo, o MP41...

P.L. Bem, o MP41 foi criado para o mercado externo, ele tinha... o problema da desmontabilidade era um componente importante do briefing do projeto, e a criação de formas que misturavam... ele é um bom exemplo do que significa a industrialização com uma cara artesanal, esse é um ponto importante no $41 \ldots$ a estrutura dele era toda em perfis que saíam prontas das máquinas, perfis ovais, então era uma ferramenta específica construída pra produzir aquilo em grande quantidade. Então, ele tinha assim um aspecto de artesanal mas, ao contrário disso, ele era totalmente massificado na produção, não entrava mão de obra... agora, na parte do estofamento, ele tinha costuras, aí vêm os truques na fabricação... o couro era de péssima qualidade na época, as peles eram pequenas, então eu aproveitava o defeito para transformar o defeito em vitória ao fazer o corte do couro em pedaços pequenos, com isso aumentava a rentabilidade do couro, evitava desperdício, o aproveitamento das peles de couro era enorme... e aquela parte que tinha as emendas, elas eram acabadas manualmente, então, aí é que aparecia a parte artesanal, que era um fator importante na venda do produto. Então era uma concepção do produto altamente industrializado, mas que tinha uma cara de produto feito à mão, então esse trabalho manual que existia, mas era uma parte menor no valor integral do projeto. Então eram pessoas que não eram tapeceiros, eram aprendizes que eram treinados para fazer aquela operação, então a característica de alta produção em série era justamente a de não ter profissionais especializados, então a mão de obra era treinada para determinadas operações, e com isso viabilizou o produto que foi realmente um dos sucessos maiores da história nossa... e a maneira como ele era ele era concebido, totalmente desmontado, o estofamento era feito ainda ainda com lâminas de espuma, não era moldado, então permitia que ele ficasse flex, ficava chato, ficava como um colchão.

G.G. E com relação ao desenho, tem alguma consideração? Que ele tem os pés inclinados, ele quase desafia, né... esta gravidade da estabilidade... 
P.L. Bom, o desenho é o que ele é, né... então é a expressão daquilo... de criar aquela forma daquela maneira com aqueles detalhes construtivos e o resultado que ele oferece... é um produto que oferecia um conforto bastante bom, e a concepção da forma que era a parte artística do projeto, talvez seja esse um dos segredos de misturar... de conseguir harmonizar a parte de forma com a parte construtiva, a parte racional e passível de industrialização.

G.G. Ele teve muitas derivações, quer dizer... do que que ele era composto? então quais eram as formas, quais eram as tipologias? E, ele teve variações de desenho ao longo da produção?

P.L. Não, o 41 ele teve ao longo do tempo pequenas variações, mas ele tinha variantes, inicialmente poltrona e sofá, sofá de dois tamanhos, para duas pessoas ou para três... era composto de madeira maciça, perfis cromados, detalhes cromados que sustentavam cintas de couro de sola, sobre essa cinta tinha o corpo que era moldado, moldado manualmente nesse caso, e posteriormente eu fiz uma outra variante usando a mesma concepção de forma mas, colocando o corpo numa posição mais baixa para adicionar um apoio de cabeça que era colocado em cima, uma estrutura separada...

G.G. A estrutura dele teve variação ao longo do tempo?

P.L. Não...

G.G. De quando que é o MP41?

P.L. 68, eu acho...

G.G. E o MP51?

P.L. 51 já é uma forma bem diferente, uma forma muito mais retilínea, seguindo os mesmos princípios, mas uma forma totalmente diferente... Os componentes, aí já entrou no período das espumas moldadas, as almofadas, da solda eletrônica para criar gomos... o 51 era injetado. 
